\title{
A arte de se construir cidades em meio à política local: Ribeirão Preto, 1890-1960.
}

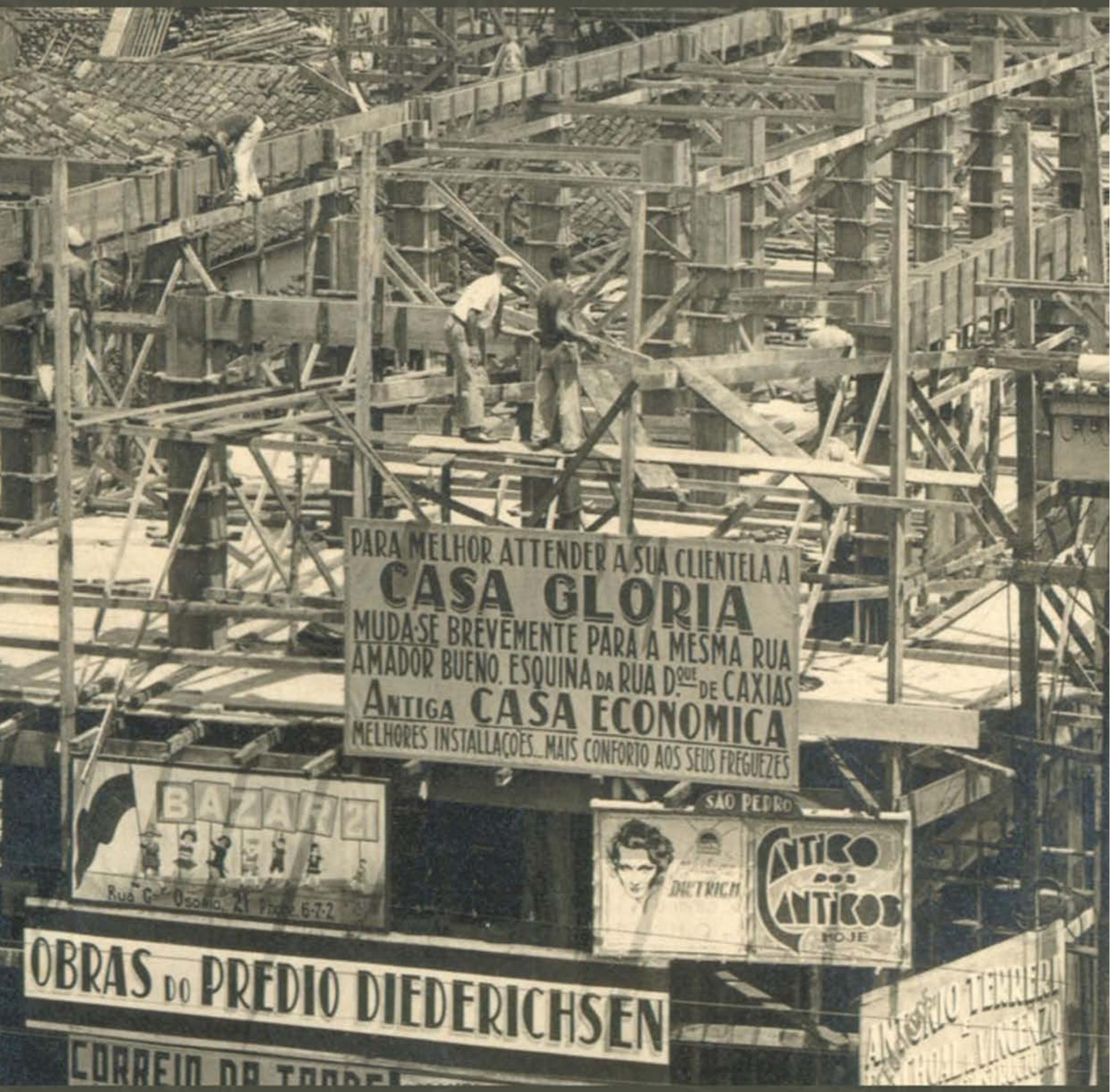

dissertação de mestrado

Daniel Deminice

São Carlos 




\title{
UNIVERSIDADE DE SÃO PAULO INSTITUTO DE ARQUITETURA E URBANISMO. \\ Programa de Pós-Graduação em Arquitetura e Urbanismo
}

\section{A arte de se construir cidades em meio à política local: Ribeirão Preto, 1890-1960.}

\author{
DANIEL DEMINICE
}

Dissertaçào apresentada ao Programa de Pós-Graduação em Arquitetura e Urbanismo do Instituto de Arquitetura e Urbanismo da Universidade de São Paulo (IAU-USP) como requisito para a obtenção do título de mestre.

Orientador: Prof. Dr. Carlos Roberto Monteiro de Andrade.

Financiamento:

Fundação de Amparo à Pesquisa do Estado de Sào Paulo. [13/02487-4]

Sào Carlos 
AUTORIZO A REPRODUÇÃO TOTAL OU PARCIAL DESTE TRABALHO, POR QUALQUER MEIO CONVENCIONAL OU ELETRÔNICO, PARA FINS DE ESTUDO E PESQUISA, DESDE QUE CITADA A FONTE.

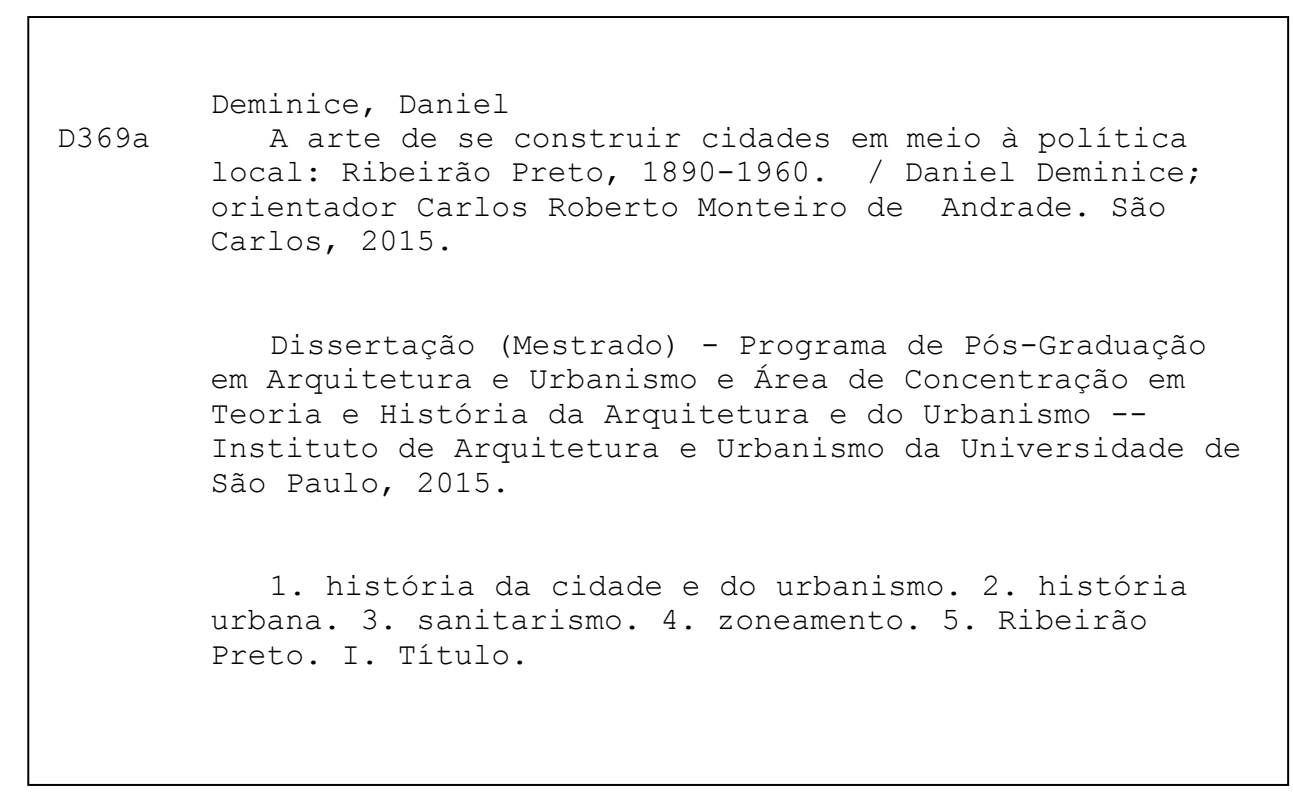






\section{FOLHA DE JULGAMENTO}

Candidato: Bacharel em História Daniel Deminice

Título da dissertação: "A arte de se construir cidades em meio à política local: Ribeirão Preto, 1890-1960".

Data da defesa: 13/05/2015

\section{Comissão Julgadora:}

Resultado:

Prof. Dr. Carlos Roberto Monteiro de Andrade (Orientador)

Aprovodo (Instituto de Arquitetura e Urbanismo - USP)

Prof. Dr. Paulo César Garcez Marins

(Museu Paulista - USP)

Prof. Dr. Rodrigo Santos de Faria

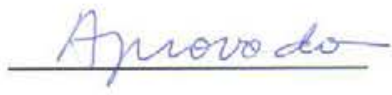

(Faculdade de Arquitetura e Urbanismo - UnB)

Coordenador e Presidente da Comissão de Pós-Graduação do Programa de PósGraduação em Arquitetura e Urbanismo: Prof. Dr. Márcio Minto Fabrício 



\section{Agradecimentos}

Sendo um leitor de textos de agradecimentos, como poderia ter reservado tão pouco tempo para escrever os meus? A poucas horas do depósito da dissertação, quase no calor da gráfica, os escrevo apressado. A memória enccurtada e a vista cansada do acúmulo de luz da tela do meu computador serão as desculpas pela injustiça de algum esquecimento. Para todos aqueles que não se sentirem retribuídos com essas poucas palavras, peço mais um pouco de compreensão. Esta pesquisa não teria sido possível sem a ajuda e o trabalho de muitas pessoas a quem desejo a oportunidade de lerem esse singelo agradecimento.

Em primeiro lugar, agradeço aos meus pais pela minha criação e pelo acolhimento nas horas mais complicadas e difíceis. Agradeço ao meu orientador, Mancha, pelas longas conversas de ensinamentos, mas principalmente pela amizade que acabamos construindo nesse breve período do mestrado. Não posso deixar de agradecer também aos outros professores do Instituto de Arquitetura e Urbanismo de São Carlos, com quem pude aprender não só através das disciplinas, mas em diversos momentos de convívio pelos corredores da escola - Sarah Feldman, Cibele Rizek, Rui Sardinha, Telma de Barros, Eulália Negrelos e Akemi Ino. Agradeço particularmente aos professores da qualificação, Paulo Cesar Garcez Marins e Sarah Feldman, pela banca que realizaram na véspera do carnaval de 2014 e, especialmente, pelo texto da arguição deixado pelo professor Paulo .Agradeço também ao Rodrigo dos Santos de Faria, que veio de longe a São Carlos para compor finalmente a banca de defesa junto ao Paulo.

Aos professores e companheiros de Grupo Urbis: Francisco Sales, Luciana Schenk, Elisângela, Maristela, Lucas, Rodrigo, Ana Carolina, Silvia, Fabrício e Leonardo. Também um abraço aos amigos de São Carlos que se tornaram mais próximos no mestrado, mas que já começam a se afastar em virtude do andamento da vida - à Milena, ao Arthur, à Clarissa, ao Claudio, ao Fausto, à Nana e, mais especialmente, ao José, que teve a paciência de manter a alegria durante o tempo que pudemos dividir moradia. Agradeço muito ao Rafael Carmargo, companheiro que nos recebeu em sua casa durante mais de dois anos: a sua forma de enxergar a vida, além de sua sabedoria sobre arquitetura é uma inspiração. Também em São Carlos agradeço ao Tiago e à Anais pela oportunidade do Canteiro Escola e, principalmente, ao Gilson e à Meire que nos receberam no assentamento Nova São Carlos para a construção da nova morada da família.

Em Ribeirão Preto agradeço bastante aos funcionários do Arquivo Público e Histórico da cidade, principalmente por toda a ajuda que eu recebi em meio ao momento difícil que o Arquivo atravessa já a bastante tempo. A eterna postergação da construção de sua nova sede gera problemas imensuráveis ao cuidado do acervo. Assim, agradeço ao Mauro, à Tânia, à Lúcia e ao Arthur pelo trabalho hercúleo de manter o Arquivo Histórico literalmente de pé. Sem esse apoio que me foi dado na consulta das fontes desse acervo não seria possível qualquer narrativa nessa dissertação. 
Ainda em Ribeirão Preto, agradeço à Paula e ao Nilton, pelas conversas sobre a pesquisa e por uma planta histórica sobre a cidade que me foi dada por eles. Também agradeço à Valéria Garcia pelas conversas em alguns encontros no Arquivo e por ter terminado sua tese a tempo de minha leitura ainda no mestrado. Em São Paulo agradeço pela estadia sempre garantida pelo Pedro Watanabe e pelo Bruno Cícero, meus amigos há bastante tempo.

Agradeço o trabalho de revisão antes da banca feito por Danilo Brich dos Santos, que além de revisor faz o papel de amigo há mais de uma década. Também pelo mesmo papel de amigo revisor, agradeço ao Tadeu Breda pelas últimas correções antes da entrega definitiva. Pela companhia e esforço de última hora, agradeço à Talita pelas leituras, pela realização da capa, pelo tratamento das imagens, pela preparação das plantas em A3, pela organização da impressão e por toda a diagramação do texto feita durante a última madrugada antes da entrega. Sem o carinho dela acredito que toda essa empreitada teria sido ainda mais penosa.

Por fim, agradeço a CAPES e a FAPESP pelo financiamento da pesquisa. 




\section{RESUMO}

A cidade de Ribeirão Preto durante a primeira metade do século XX foi construída em meio à atuação profissional de personagens de diferentes matizes. Entre relatórios técnicos, planos urbanos e discursos políticos, notamos que diferentes representações urbanas se tornaram motivo de polarizações político-partidárias na atividade institucional da Câmara Municipal. Isso nos levou a abordar a complicação desses interesses em dois momentos históricos da formação da cidade de Ribeirão Preto. Durante a Primeira República, frente aos discursos dos Intendentes Municipais e a atuação da Empresa de Água, colocamos em evidência as concepções urbanísticas de Saturnino de Brito no que tange a implantação da rede de abastecimento d'água e a crise desse recurso hídrico em 1912 na cidade. Num período subsequente, a partir dos anos 30, diante de uma ocupação mais abastada ao sul do município, procuramos contrapor as representações dessa ocupação ás diretrizes do Plano Diretor elaborado pelo urbanista José de Oliveira Reis em 1945. Ao final desses dois períodos, vimos a consolidação das vertentes de crescimento da cidade se definir entre o norte, como o território de fábricas e moradias populares, e o sul, como o espaço de bairros residenciais e serviços comerciais elitizados. Desse modo, o objetivo da pesquisa foi enquadrar a configuração urbana de Ribeirão Preto não apenas como um cenário material, mas como o resultado de interesses políticos, urbanísticos e financeiros.

Palavras-chaves: História das Cidades e do Urbanismo; Primeira República; Estado Novo. 



\section{AbSTRaCT}

During the first half of the twentieth century the city of Ribeirão Preto was built in the midst of the professional performance of characters of different shades. Among technical reports, urban plans and political speeches, we perceived that different urban representations were the cause of political polarizations in the institutional activity of the City Council. This led us to approach the aggravation of these interests in two historical moments in the Ribeirão Preto's city formation. Initially, during the First Republic, comparing the speeches of Municipal Managers and the Water Company's actions, which concerned the implementation of its supply network and the lack of water resource crisis, we put in evidence the urban conceptions of Saturnino de Brito, who even elaborated a report about the water management in the city. In a subsequent period, from the 30 s, regarding the wealthy occupation of the southern highlands of the municipality we contrapose representations of this occupation with elements of the Master Plan elaborated by urban planner José de Oliveira Reis in 1945. At the end of these two periods, we saw the consolidation of two aspect of the city's growth characterized in the north as the territory of factories and affordable housing, and in the south as the space of residential neighbourhoods and elitist commercial services. Thereby, the aim of this research was not only to portrait the material scenario of Ribeirao Preto's urban configuration, but also to portrait it as the result of political, urban and financial interests.

Key-words: Urban Plan and City History; First Republic; New State. 

$\begin{array}{ll}\text { INTRODUÇÃO } & 19\end{array}$

CAPÍTULO 1

1.1 Dois profissionais do urbanismo.

1.2 A política moderna brasileira. $\quad 40$

1.3 Plano de Conjunto contra o domínio patriarcal?

1.4 Plano Diretor politicamente neutro?

$\begin{array}{ll}\text { CAPÍTULO } 2 & 59\end{array}$

2.1 A ocupação da bacia hidrográfica do Ribeirão Preto. 61

2.2 A cidade entre rios.

2.3 A construção da rede de água e esgoto.

2.4 A política na cidade republicana.

2.5 As polêmicas em torno dos mananciais.

2.6 O monopólio sobre os recursos hídricos. 119

$\begin{array}{lr}\text { CAPÍTULO } 3 & 129\end{array}$

3.1 O crescimento do arrabalde da capital d'oeste. 131

3.2 A ocupação da parte alta da cidade. 140

3.3 A política na cidade após 1930.

3.4 Um projeto de Plano Diretor.

3.5 Os loteamentos residenciais da zona sul de Ribeirão Preto. 183

A ARTE DE SE CONSTRUIR CIDADES EM MEIO À POLÍTICA LOCAL 199

$\begin{array}{ll}\text { FONTES } & 209\end{array}$

REFERÊNCIAS BIBLIOGRÁFICAS

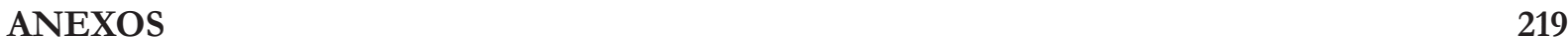



INTRODUÇÃO 

Ao iniciar uma pesquisa sobre a história de Ribeirão Preto se coloca a tarefa de produzir uma narrativa em que se evidencie um novo olhar sobre a cidade. Muito já foi escrito sobre o passado dessa cidade entre memorialistas, historiadores e arquitetos, desde seu processo de formação, notadamente pelo desenvolvimento econômico de seu período cafeeiro, até se chegar aos fatores que a dotaram de uma feição mais urbano-industrial na metade do século XX. Todavia, como diria Bernard Lepetit (2001): "o passado não se conserva, mas constitui o objeto de uma reconstrução sempre recomeçada"1. O ofício do historiador possui uma dimensão autoral no tratamento dos acontecimentos históricos que lhe dá um aspecto sempre de inacabado. Como mais uma vez diria Lepetit: "deus não refaz o mundo a cada dia, mas, de certa maneira, os historiadores o fazem"'.

Diante disso partimos da ideia de que ser humano em sua natureza possui uma curiosidade intrínseca sobre os acontecimentos passados, o que faz com que a História, dentro de um campo científico, possua menos um caráter lógico-dedutivo, estando mais assentada sobre um modelo epistemológico indiciário. Algo que se afirma nas ciências humanas ao final do século XIX com as transposições de métodos investigativos das ciências médicas. e faz com que o conhecimento histórico se consolide essencialmente como um conhecimento perspectivo, não tendo portanto uma dimensão absoluta. De forma invariável, mesmo em meio a correntes estruturalistas, sempre dependeremos do olhar do historiador ao lermos sobre os temas de reflexão que se constituíram no âmbito da história das cidades e do urbanismo.

Nesse sentido, qual seria o interesse particular dessa dissertação ao extrair outras representações de uma realidade esquecida ou não enfocada de Ribeirão Preto? Por quais motivos realizar novas interrogações sobre passado dessa cidade? Partimos de diversos temas que não são novos na historiografia das cidades brasileiras e que já foram estudados em diversas áreas do conhecimento. Contudo, para não nos perdemos no caminho, ou melhor, para que a cada desvio possamos nos reencontrar; temos como pano de fundo dessa pesquisa a forma urbana que a cidade de Ribeirão Preto adquiriu ao longo da primeira metade do século XX, sendo talvez o legado que mais se ressalta na sua atual configuração urbana.

Segundo Marcel Roncayolo (1988:10):

Las formas urbanas son el producto de la historia; en el término "ciudad", más que um concepto riguroso, se reconece la acumulacion de uma suma de experiências históricas. Em esse sentido, el fin de

1 LEPETIT, B. Arquitetura, Geografia, História: Usos de Escala. in: Salgueiro, H. A. Por uma nova história urbana, 2001. p. 223.

2 Idem, p.225. 
la ciudad podria ser sustituido por uma reflexión general sobre las formas espaciales y su relación com las sociedades.

A dissertação pretende abordar a história urbana de Ribeirão Preto no que diz respeito aos aspectos sociais e institucionais de sua construção material. Entretanto, procuramos investigar o desdobramento de tais arranjos institucionais no crescimento da cidade em dois momentos distintos no sentido de demonstrar episódios cruciais de sua configuração espacial. Portanto, num recorte de média duração, nos situamos nos decênios da primeira metade do século XX com as seguintes perguntas: quais teriam sido as implicações sanitárias na formação urbana de Ribeirão Preto em meio à política da Primeira República? E, em seguida, já ao final dos primeiros 50 anos do século XX, como se desdobra em Ribeirão Preto a elaboração e a tramitação do seu primeiro projeto de Plano Diretor já sob uma nova configuração política e institucional?

A cidade de Ribeirão Preto, acompanhando os episódios remontados por essa pesquisa, se tornou ao longo desse período profundamente marcada por uma fronteira social e material entre os seus lados norte e sul. O norte do município se consolida como o território de produção desde o ciclo cafeeiro. Situado numa região mais baixa da cidade os seus terrenos são ocupados por sitiantes que abasteciam a cidade rica. O lado sul, ao contrário, se revestiu como um cenário burguês numa região mais alta onde foram instalados tradicionalmente os equipamentos salubres da cidade moderna. Em suma, enquanto de um lado o território das chácaras que abasteciam o núcleo urbano se transforma no espaço de moradias populares e fábricas, de outro as glebas altas se tonaram, ao final da metade do século XX, o lugar de bairros mais abastados socialmente.

A demonstração desse processo de formação urbana, entretanto, não é inédita e já foi evidenciada por alguns autores entre os quais destacamos: Adriana C. Silva (2007), que a apresenta principalmente através da constatação de que os bairros que se originaram do Núcleo Colonial Antônio Prado receberam durante a Primeira República os equipamentos considerados insalubres segundo a ideologia higiênica. Mesmo antes desse período, aponta a autora, ainda durante o Império, esta região se consolida como território popular com a demarcação dos terrenos nacionais devolutos para abrigar o núcleo colonial de imigrantes.

Em meio à constituição de um território que abrigaria ricas fazendas, a criação do Núcleo Colonial em 1887 integra o projeto do Governo Imperial de fixar mão de obra estrangeira junto ao avanço da agricultura cafeeira. Ao final da escravidão, também com a intenção de modificar a aparência e o perfil dos trabalhadores da região, o incentivo à imigração de estrangeiros é iniciado em Ribeirão Preto. Todavia, diante do temor das epidemias, as medidas do urbanismo sanitário realizaram o afastamento dos focos de contaminação e doenças despachando para o território do Núcleo tudo aquilo que era indesejável à cidade burguesa.

Numa trajetória de pesquisa inversa, entre essas “duas cidades” separadas pelos leitos do córrego Retiro e Ribeirão Preto, Rodrigo Faria (2010) irá selecionar como objeto de pesquisa justamente a construção da cidade Entre Rios. O autor demostra como os discursos visuais da cidade viabilizaram a construção de um cenário urbano composto, basicamente, por palacetes, praças, teatros, calçadas e jardins.

Faltava apenas delimitar quais áreas da cidade seriam beneficiadas, para quem a cidade se modernizaria, e para quem o progresso continuaria somente um desejo, materializado no olhar bestializado com a divisão daquele ambiente urbano em "duas cidades": uma intra-rios, moderna, higiênica e embelęada, 
outra, além-rios, desprovida das melhorias que acompanhavam esse trinômio da cidade burguesa (FARIA: 2010: 51).

Na obra Ribeirão Preto, uma cidade em construção, o autor demonstra como aquele espaço da cidade absorve de forma privilegiada os melhoramentos e embelezamentos do ciclo urbanístico republicano. Tais melhoramentos urbanos irão coincidir com o traçado da tubulação da rede de água e esgoto definido no projeto de abastecimento da Comissão de Saneamento do Estado de São Paulo. Através de um saneamento restrito ao perímetro central de Ribeirão Preto desenhava-se um zoneamento social e urbano na cidade entre uma área protegida pelas águas dos rios, objeto de uma vida urbana ideal e outra, periférica, além das margens dos córregos, que seria ocupada por trabalhadores e fábricas.

No traçado estabelecido pelo projeto apresentado pela Comissão de Saneamento, é quase definida uma grande área central da cidade, como se no plano estivessem sendo traçados os limites considerados urbanos, ou o perimetro urbano da cidade. Para além dele, os mesmos problemas de falta de infraestrutura não foram considerados, e a população moradora desses localidades permaneceriam, portanto, sem as melhorias da área central (FARIA: 2010: 79)

Rodrigo Paziani (2004), em sua tese Construindo a Petit Paris, também irá demonstrar a divisão espacial da cidade, principalmente como consequência das ambiguidades da modernidade ribeirão-pretana. O autor se concentra nas intervenções urbanas capitaneadas pela Intendência Municipal do médico baiano Joaquim Macedo Bittencourt. A própria figura dessa personagem é significativa das contradições que irão moldar o espaço urbano ribeirão-pretano. O médico-prefeito, atuando como um "Fausto Caipira", emerge socialmente em meio aos progressos urbanos gerados pela riqueza do café. Dessa maneira ele irá pautar o discurso civilizador da modernização definindo como polos antagônicos a cidade-virtude - positiva, enaltecedora do progresso e da razão, e a cidade-vício - repleta de costumes e situações cotidianas tidas como arcaicas.

Para Bittencourt a afirmação da cidade-virtude passava por um gesto de civilizar e reformar o coração da cidade de seus moradores. Daí, as expectativas das elites ribeirão-pretanas em conceber a cidade civilizada segundo normas de condutas instituidas por lei. Ao mesmo tempo, equipar o centro com serviços urbanos ou belos prédios tornavam-se estratégias de ocultamente da barbárie e de controle do poder público contra a cidade-vício (PAZLANI: 2004: 180).

Karla Sanches (2003), em sua pesquisa sobre a construção dos Códigos de Posturas e de outras Leis sobre a regulamentação do uso e ocupação do solo urbano de Ribeirão Preto, também irá demonstrar como essa legislação urbanística antecessora das leis de zoneamento dos anos 1950 se acopla como um instrumento de planejamento urbano à determinação de interesses privados no crescimento da cidade. A legislação urbanística da Primeira República, e também a da Era Vargas, funcionou basicamente na medida dos interesses de grupos dominantes sobre os espaços da cidade, já que possuía uma dimensão de reequilibrio social bastante marginalizada. Através da análise dessa legislação, a autora demonstra como a criação da taxa de localização das indústrias situadas nas $1^{\mathrm{a}}$ e $2^{\mathrm{a}}$ Zonas - região central da cidade - evidencia a intenção da Câmara Municipal promover a locomoção das fábricas para a $3^{\text {a }}$ Zona de Ribeirão Preto - região norte. A isenção da taxa de localização industrial às fábricas da $3^{\mathrm{a}}$ Zona consolida àquele zoneamento social da cidade. Por fim, a adoção do Código de Obras Arthur Saboya, em 1933, consagra o zoneamento urbano de Ribeirão Preto segundo a tendência norte - sul.

Diante dessa historiografia local procuramos nos situar realçando essa fragmentação urbana 
adquirida em dois contextos históricos específicos da produção da cidade. Um primeiro que envolveu o tratamento das águas de abastecimento urbano, passando pela construção de sua rede de distribuição pela Empresa de Água e Esgotos de Ribeirão Preto. Nesse período, a atuação da Empresa no que concerne ao sistema de abastecimento acaba sendo contraposta pelos relatórios produzidos por engenheiros sanitaristas, sobretudo o de Saturnino de Brito que visita a cidade diante da polêmica sobre os mananciais em 1912. Já o segundo contexto histórico está relacionado à ocupação da parte alta da cidade, quando a despeito das delimitações do perímetro urbano definidos pelo projeto de Plano Diretor em 1945 há uma eclosão de loteamentos imobiliários. Essa distensão da cidade pelos loteamentos acaba contrariando as prescrições do urbanista José de Oliveira Reis, que através de uma nova proposição de zoneamento pretendia mudar a forma da cidade.

Para melhor situá-los procuramos analisar os dois períodos sob os dilemas políticos enfrentados pelos dois urbanistas que passaram pela cidade. Dessa forma, inevitavelmente o recorte temporal se estende ao longo de toda a primeira metade do século XX, ressaltando sobretudo os dilemas que envolveram os dois engenheiros nos seus respectivos contextos históricos. Todavia, para a historicidade da pesquisa não se tornar excessiva, a narrativa se circunscreve a partir desse parâmetro de particularidade, qual seja - a história urbana de Ribeirão Preto e o diálogo com as leituras e concepções urbanísticas de Saturnino de Brito e José de Oliveira Reis.

Os documentos produzidos pelos engenheiros foram: i) a elaboração por Saturnino de Brito de um relatório sobre o abastecimento de água de Ribeirão Preto, quando no bojo das obras de melhoramentos e embelezamentos realizadas durante a Primeira República se construiu o sistema de abastecimento d'água. E no segundo momento: ii) a elaboração do projeto de Plano Diretor em 1945, quando em meio ao boom de loteamentos imobiliários na década de 1940, o urbanista José de Oliveira Reis argumenta contra o crescimento desenfreado da cidade.

A baliza da narrativa parte da seguinte premissa: invariavelmente os planos urbanos, independente de suas concepções e matrizes urbanísticas, necessitam atravessar uma dimensão política e institucional para se concretizar em modificações materiais na cidade ou mesmo para se transformarem em leis de ordenamento urbano. Como diria Marcel Roncayolo (1988: 105):

El hecho politico está presente por todos lados en la ciudad. La ciudad ejerce funciones politicas o administrativas con respecto a un território más o menos vasto, participa em la organización del territorio, dirige además sus propios assuntos.

Perpassa, em ambos os recortes, tanto o que envolveu Saturnino de Brito no que toca às suas reformas de saneamento e higiene, quanto ao que envolveu José de Oliveira Reis no que se refere à especulação imobiliária, aquilo que Paulo Cesar Garcez Marins (1998) definiu como a tentativa de implantação nas cidades brasileiras da fragmentação do tecido urbano, ou melhor, um projeto de repartição dos espaços da cidade adequado aos padrões burgueses de controle das diferenças sociais. Os urbanistas, em alguns trechos dos planos, são contrários a esse desenvolvimento fragmentado da cidade, porém, muitas vezes são absorvidos pelos interesses políticos e econômicos locais. Desse modo, procuramos abordar uma face dos dilemas e entraves da absorção de um novo modelo urbano forjado como expressão de uma vontade reformista das elites brasileiras. Ao passarem a habitar as cidades durante a primeira metade do século 
XX, os grupos sociais dominantes irão tensionar a modificação dos cenários urbanos ao encontro de suas perspectivas ideológicas.

A imagem utilizada na capa da dissertação é representativa desse nódulo da história de Ribeirão Preto - a construção do edifício Diederichsen, na década 1930, localiza-se justamente entre os dois períodos recortados pela dissertação, podendo bem servir de marco divisório dos dois momentos destacados neste trabalho. O prédio é erguido no lote antes ocupado pelo casarão de Joaquim da Cunha Diniz Junqueira. Substitui, portanto, a antiga edificação feita nos moldes dos códigos de construção republicanos que servia ao influente político local para articular seus interesses no Diretório Municipal do Partido Republicano Paulista. O Edifício Diederichsen simboliza nesse sentido um movimento de mudança do imaginário político republicano para outro mais próximo ao mundo urbano industrial, marcando a transição da Primeira República para a Era Vargas.

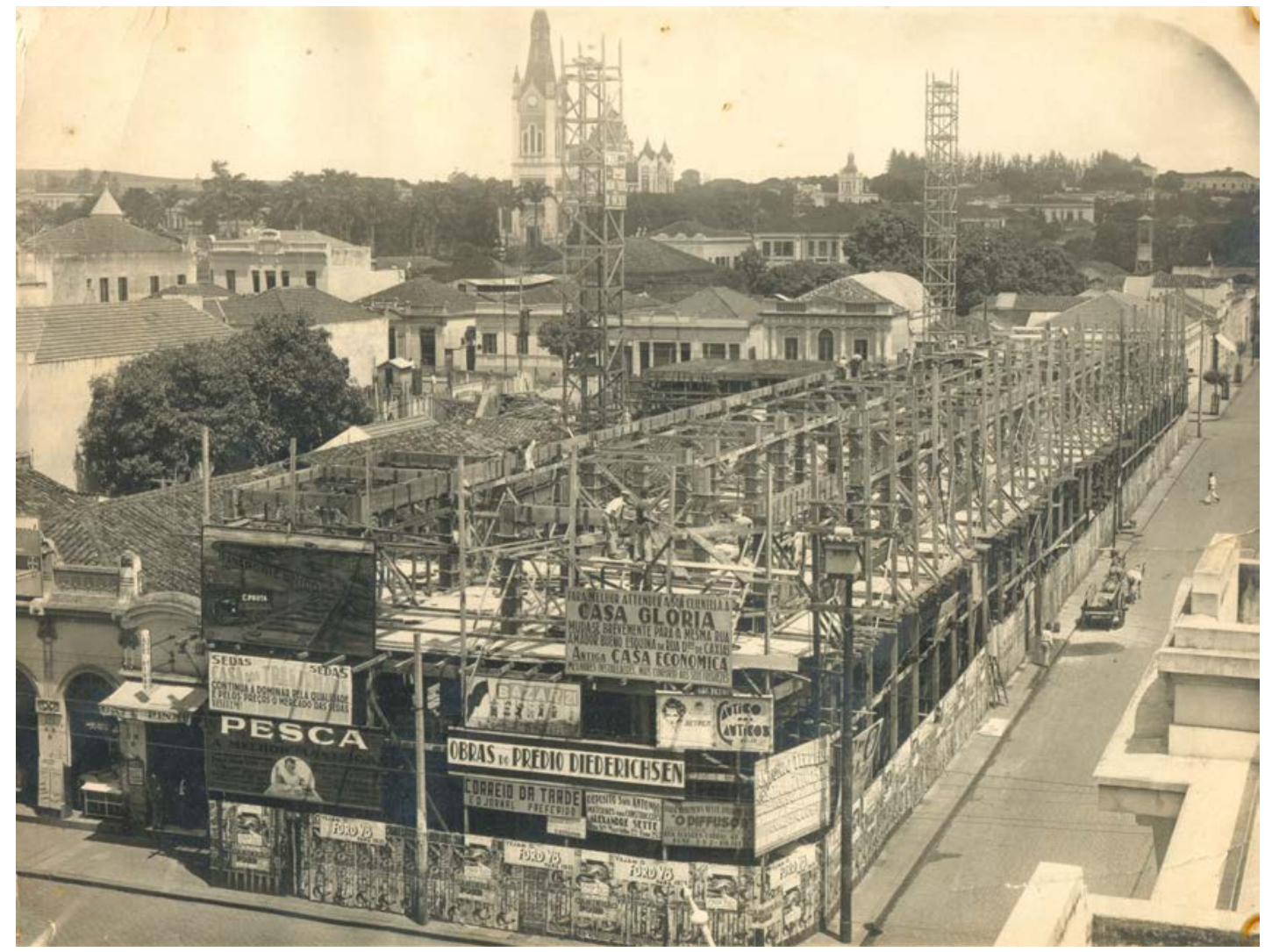

Figura 1: construído na década de 1930, o Edifício Diederichsen simboliza uma transição da cidade. Fonte: APHRP.

Erguido em concreto armado, o edifício é inaugurado em 1938 como o mais alto da cidade com seis pavimentos distribuídos segundo a adoção de um programa moderno de diferentes usos. Dessa maneira, os inúmeros cômodos do casarão de Joaquim Diniz da Cunha Junqueira são substituídos pelos apartamentos de classe média, pelas salas comerciais e ainda por um cinema e um hotel. O prédio representa portanto o início da mudança de um espaço que deixará de ser composto por palacetes e sobrados ao redor de um jardim afrancesado para ser um lugar de passagem, o centro comercial de uma cidade maior e mais fragmentada.

Tendo esse processo de transformação da cidade de Ribeirão Preto como o objeto de pesquisa, a pretensão é remontar os episódios históricos do período em questão a partir do conceito 
de história-problema. Suporte metodológico levantado por autores de História Urbana da terceira geração da Escola dos Annales ${ }^{3}$, que propõe em seus trabalhos uma articulação entre a produção ou recriação dos espaços urbanos e os processos de remodelações institucionais realizados pelos interesses do grupos sociais que habitam as cidades. Nessa linha estão as pesquisas descritas por Bernard Lepetit que demonstram os sentidos das instituições no que se refere às práticas de seus atores sociais e, consequentemente, as implicações no espaço urbano dessa atuação. Segundo tais trabalhos, a cidade dispõe de uma materialidade moldada por quem a ocupa, sendo redutora a abordagem que apenas realiza a descrição da transformação material separada da análise da atuação dos grupos urbanos para a compreensão de uma sociedade. O espaço urbano é um local de contraste e de disposição valorativa dos homens e suas coisas, não tendo a cidade uma natureza própria, mas sendo resultado do social. Assim, pensar a correspondência entre as instituições sociais e a organização material urbana é importante para entender a construção do desenho urbano e da configuração social de qualquer cidade.

Incorporamos a noção de que os atores históricos atualizam os seus sistemas de representações para nos debruçarmos sobre os objetos desta pesquisa com duas chaves de entendimento: Instituições e Espaços. i) Instituições: procurando entender os seus sentidos sociais, as aptidões que elas possuem para modelar a sociedade. ii) Espaço: a cidade não apenas como um cenário de acontecimentos sociais e econômicos, mas como uma construção da sociedade. ${ }^{4} \mathrm{~A}$ cidade de Ribeirão Preto foi moldada, nos dois momentos históricos recortados por essa pesquisa, por um arranjo de posições (institucionais e espaciais) relativamente ocupadas pelos seus moradores. Num primeiro momento, as obras de melhoramentos e embelezamentos constroem uma "outra" cidade "moderna" e, de certa maneira, determina os lugares de cada uma de suas classes sociais. No segundo, se aprofunda tal divisão no bojo do crescimento da cidade e da formação de seus bairros.

O conjunto dos recursos sociais disponíveis - posição espacial e apropriação institucional - molda um sistema urbano em Ribeirão Preto. Neste sentido, a presente dissertação, ao propor analisar o efeito de combinação - espaço e instituição - que não é necessariamente igualitário ou harmônico, mas apropriado pelo valor que possuí para imposição de um arranjo desigual, justificase por permitir uma investigação da história da cidade sob uma nova perspectiva.

Por um outro lado, a justificativa da dissertação também parte da premissa de que o estatuto da História, como sugeriu Edgar de Decca (1991), se inicia justamente com a sua escrita,

3 Ou pela historiografia que Bernard Lepetit descreve como uma espécie de História Imediata, que teria começado nos anos 1980 após o impacto do livro de Jean Claude Perrot, Genèse d'une ville moderne. Caen au XVIII siècle. Os autores apontados por ele como pertencentes a essa geração são: Simona Cerutti, que estudou a eclosão de alianças e a institucionalização de grupos urbanos oriundos das corporações de ofício em Turim do século XVII; A. Farge e J. Ravel, num trabalho sobre o processo de desafeição a Monarquia francesa; e, Bernard Lepetit, numa obra sobre a noção de sistema urbano, ver LEPETIT, B. A cidade moderna na França. Ensaio de História Imediata. in: SALGUEIRO, H. A. (org.) Por uma nova história urbana. EDUSP, São Paulo, 2001. Sobre a classificação dos historiadores da Escola dos Annales divididos em três gerações, ver Burke, Peter. A escola dos Annales (1929-1989). A revolução francesa da historiografia. $2^{\circ}$ Ed., Unesp: São Paulo, 1992. Uma discussão sobre a relatividade da possibilidade dessa categorização é feita em Lepetit, Bernard. Los Annales, hoy. Istapalapa 36, enero e junio de 1995.

4 "A cidade em si, palco e personagem, produto e produtor, origem e resultado." Lapa, José Roberto do Amaral. A cidade os cantos e os antros. Campinas, Ed. da Unicamp, 2008. 
dependendo portanto de todos os dilemas dessa narrativa. ${ }^{5}$ Assim, o próprio objeto de pesquisa deriva da demonstração do texto narrativo, ou seja, ele é aquilo que o historiador constrói em sua trama num referencial artificial de tempo.

Segundo Braudel (1992: 44):

Todo trabalho histórico decompõe o tempo passado e escolhe as suas realidades cronológicas segundo preferências e exclusões mais ou menos conscientes. (...) Desta forma, existe hoje, a par da narração (ou do "recitativo") tradicional, um recitativo da conjuntura que para estudar o divide em amplas seģões.

A narrativa, como um artifício laboratorial do historiador, acaba sendo marcada por escolhas e pela estrutura do próprio texto. A sua historicidade se forma na medida dessa construção. Diante do enquadramento narrativo, portanto, reforçamos um problema que não é novo na historiografia das cidades e do urbanismo - isto é, os projetos e planos urbanísticos dependem, principalmente, no caso brasileiro, da tramitação em esferas políticas e institucionais para se materializar na cidade. Frente às clivagens entre o discurso e a materialidade urbana, Argan (1992) diria que o que impede a formação de cidades modernas seria uma oposição entre duas tendências: uma conservadora a dos governantes - que enxerga os problemas em termos quantitativos, propondo soluções de compromissos ligados aos interesses da especulação imobiliária, e outra dos reformadores - a dos urbanistas - que enxergam os problemas em termos estruturais propondo soluções mais rigorosas.

De modo que:

A bistória do urbanismo é, portanto, a história do conflito entre uma ciência voltada para o interesse da comunidade e a aliança dos interesses e privilégios privados; uma história de programas irrealizados e de intervençöes parciais. Ainda boje se pede aos urbanistas que façam propostas e projetos, mas o poder de decisão permanece com os políticos ou os burocratas. (ARGAN: 1993: 186)

Dessa forma, procuramos costurar o diálogo entre duas peças ou planos urbanos como matrizes e discursos do pensamento urbanístico, e o seu trânsito pela Câmara Municipal de Ribeirão Preto enquanto esfera política-institucional de poder local. $\mathrm{O}$ circuito dessas ideias, debates e articulações políticas, resvala na construção de equipamentos urbanos - a rede de água e esgoto - e os espaços da cidade - os loteamentos residenciais da zona sul.

Outros trabalhos essenciais a esta pesquisa foram aqueles que abordaram os processos de urbanização desde cidades que acabaram se tornando metrópoles até cidades médias, como atualmente Ribeirão Preto. Mas principalmente cidades que estiveram vinculadas ao principal circuito econômico comercial da Primeira República. Assim, uma historiográfica sobre as cidades paulistas conectadas pelos trilhos das ferrovias serviu para levantar analogias entre cidade que atravessaram processos de modernização semelhantes.

Essa rede urbana formada pelo circuito da economia cafeeira remete novamente a noção

5 Depoimento feito ao grupo de arquitetos que se consolidava no primeiro Seminário de História da Cidade e do Urbanismo. Nele se assumia a importância do campo da história diante da reflexão sobre a cidade, o urbano e o urbanismo, ver DECCA, E. de. Estatuto da História. Espaço \& Debates. Cidade e História, n³4, 1991. E em PINHEIRO, E. P; GOMES. M. A. A. de. Retraçando percursos: o papel dos seminários de história e do urbanismo na constituição de um campo de estudos. In: PINHEIRO; E. P; GOMES. M. A. A. de. (org) A cidade como história. Os arquitetos e a historiografia da cidade e do urbanismo. Salvador, 2004. 
de sistema urbano levantada por Bernard Lepetit (2001) no que toca a ampliação dos transportes ferroviários e a transformação. Primeiro, de sua forma urbana, em que a cidade não se concebe mais sem a existência de um espaço que a circunda e de onde ela extrai a sua subsistência tanto material quanto humana. Segundo, a rede urbana ou à interdependência entre cidades conectadas pelos equipamentos que reforçam a estrutura de um território e, ao mesmo tempo, aceleram trocas, facilitam a difusão das inovações, uniformizam a área econômica e instauram outro funcionamento do espaço.

A abordagem se assentou, nesse sentido, sob duas entradas ou campos historiográficos específicos. O primeiro sobre as transformações urbanas da cidade de Ribeirão Preto e os personagens locais que atuaram politicamente nessa transformação, e o segundo sobre os urbanistas e o processo de institucionalização dessa profissão no Brasil. Dentro das contribuições historiográficas no âmbito dos Seminários de História da Cidade e do Urbanismo (SHCUs) levantamos alguns estudos sobre os dois momentos do urbanismo associados às trajetórias profissionais de Saturnino de Brito e José de Oliveira Reis.

A respeito da trajetória do engenheiro Saturnino de Brito utilizamos como baliza o trabalho de Carlos Roberto Monteiro de Andrade (1992) - A peste e o Plano: o urbanismo sanitarista do engenbeiro Saturnino de Brito, que aborda os projetos de saneamento e extensão realizados pelo engenheiro para dezenas de cidades brasileiras ao longo de todo o período da Primeira República. Antecipando a chegada do urbanismo moderno no Brasil por figuras como Le Corbusier, Andrade (1992) demonstra como Brito, desde a virada para o século XX vai deixando suas marcas na forma urbana de cidades como Vitória, Campinas, Santos, Recife e São Paulo.

Diversas cidades entre as quais, particularmente, nos chamou a atenção Campinas, em que Brito formula o seu sistema de saneamento baseado nos canais a céu aberto corrigindo tanto a drenagem urbana quanto a melhoria da captação de água numa cidade que crescia e vinha sendo assolada anualmente por epidemias de febre amarela. Notamos uma situação semelhante em Ribeirão Preto, porém, seus desdobramentos históricos acabam dando outra feição aos seus canais e ao seu sistema de abastecimento d'água.

Na obra de Andrade (1992) tomamos além do reconhecimento do diálogo entre os elementos da urbanística de Brito e o desenvolvimento urbano de Ribeirão Preto algo que perpassou suas concepções administrativas e políticas em todas as cidades para as quais organizou planos de reformas urbanas. Nessas localidades, Brito sempre advogou contra o domínio de oligarquias na gestão do planejamento urbano municipal, fazendo referência a uma legislação urbanística que assegurasse a integralidade dos planos dando o tom da crítica aos interesses clientelistas das administrações municipais brasileiras.

Já sobre a trajetória profissional de José de Oliveira Reis, utilizamos como referência o trabalho de Rodrigo Faria (2007), cincunscrito a um segundo período da história do urbanismo brasileiro. Persnogem da tese de Faria, o urbanista José de Oliveira Reis atua como funcionário da prefeitura do Rio de Janeiro entre 1933 e 1966, primeiro na chefia da Comissão do Plano da cidade 
e, posteriormente, na direção do seu Departamento de Urbanismo. Assim, sua formação ocorre junto ao processo de institucionalização do urbanismo nas administrações municipais brasileiras, sendo importante ao debate urbanístico no âmbito do Movimento Municipalista brasileiro.

Nosso enfoque, nesse caso, recai inicialmente em alguns comentários de Oliveira Reis enquanto historiógrafo da cidade do Rio de Janeiro, momento de de sua vida em que registra opiniões sobre gestão de Antônio Prado Junior como positiva a institucionalização do urbanismo. Em seguida, nos concentramos na confecção do Plano Diretor de Ribeirão Preto e nas polêmicas entre a Prefeitura Municipal da cidade e a Comissão Especial do Plano formada pelos vereadores de sua Câmara Municipal. Por fim, Oliveira Reis ainda deixa na cidade as suas concepções de planejamento urbano por meio da palestra que profere aos vereadores - "O Urbanismo e a sua influência no município".

Estes dois trabalhos pertencem a um grupo de arquitetos que constituíram por meio da pesquisa sobre a trajetória de profissionais o campo de estudos sobre formação do pensamento urbanístico no Brasil. Assim, estão na linha do que se consolidou como uma rede de pesquisa sobre o urbanismo brasileiro entre o período de 1895 a 1965․ Acompanhamos estes trabalhos sobre a modernização das cidades brasileiras no que concernem às ambiguidades e mazelas que as reformas urbanas geraram a partir de novas representações de cidade. Os Planos Urbanos modernos não dão conta de superar as diferenças sociais legadas pelas cidades do Brasil oitocentista, de modo que, no caso de Ribeirão Preto, apesar da cidade definir os seus vetores de crescimento principalmente durante a primeira metade do século XX, as duas peças urbanísticas que abordamos acompanharam, em certa medida, as novas configurações da desigualdade social urbana. Os dois urbanistas - Saturnino de Brito e José de Oliveira Reis - não dão conta de inverter a tendência de crescimento que acaba por fraturar a cidade de Ribeirão Preto em dois lados distintos.

\section{Fontes}

A pesquisa documental se debruçou sobre materiais referentes à história da cidade de Ribeirão Preto coletados principalmente no acervo do Arquivo Público e Histórico de Ribeirão Preto. Pesquisamos fontes produzidas pelos órgãos da municipalidade referentes aos desembargos de suas obras urbanas: as plantas e memoriais dos loteamentos residências na zona sul, os relatórios dos intendentes municipais, os balanços e pareceres referentes à construção das obras de saneamento da cidade, documentos dos fundos da Câmara Municipal e Intendência/Prefeitura Municipal.

Este material foi constituído pelo poder público face à demanda social de serviços urbanos, e a documentação se agrupa no tópico Desenvolvimento Urbano e Rural, arrolando documentos referentes à habitação, meio ambiente, obras particulares, obras públicas, uso e ocupação do solo. Também foi utilizado o tópico Serviços Municipais, que possui documentos sobre abastecimento,

6 Ver LEME, Maria Cristina da Silva. A formação do pensamento urbanístico no Brasil, 1895-1965. In Leme, M. C. da S. Urbanismo no Brasil (1895-1965). São Paulo: Studio Nobel; FAUUSP; FUPAM, 1999. 
água e esgotos, cemitérios, recursos energéticos e limpeza pública.

Os Relatórios dos intendentes/prefeitos apresentados à Câmara Municipal foram fontes gerais bastante utilizadas para compor a historicidade do que foi realizado na cidade durante a gestão de cada um dos administradores. A obrigatoriedade deste tipo de documento municipal surge com o advento republicano, o que permitiu o registro de informações básicas sobre o desenvolvimento material da cidade o que foi importante para o mapeamento que contemplou os objetivos da pesquisa. ${ }^{7}$ Nesse sentido, pesquisamos algumas Atas de sessões da Câmara Municipal pelo intuito de esmiuçar as nuances políticas dos episódios históricos abordados pela pesquisa.

As fontes referentes aos trabalhos em Ribeirão Preto da Comissão de Saneamento do Estado de São Paulo, da qual Saturnino de Brito foi integrante durante o final do século XIX, foram importantes para comparar as obras de saneamento da cidade aos modelos e tendências urbanísticas que vinham sendo realizadas por engenheiros sanitaristas contemporâneos a Brito. Esses relatórios de trabalhos da Comissão pertencem ao acervo do Arquivo do Estado de São Paulo, sendo constituídos por textos, plantas, mapas, desenhos e balanços referentes à história da cidade de Ribeirão Preto produzidos por atores sociais que transitaram pelo governo municipal, pela imprensa local, e pelo governo estadual.

Numa abordagem metodológica dessas fontes procuramos seguir a linha de autores que se concentraram sobre as problemáticas da História das Instituições. Com foco na história da cidade de Ribeirão Preto procuramos sondar através delas o sentido que as instituições municipais assumiram no que se refere às práticas de seus atores sociais e as implicações espaciais e urbanas dessa atuação. Algo que pressupôs o cruzamento do conteúdo bibliográfico com os materiais documentais levantados. Os resultados obtidos desta interseção serviram para compor uma narrativa a respeito das hipóteses da dissertação.

Em relação às inúmeras fontes iconográficas da pesquisa, partimos da obra de Boris Kossoy (2014) para tomar a fotografia como um resíduo do passado e, assim, uma fonte histórica também sujeita ao olhar do historiador. Mesmo diante de seu impacto visual, ela não substitui a realidade, sendo uma representação do passado. Procuramos abordar as imagens fotográficas numa condição semelhante a de outras fontes históricas, como uma segunda realidade, ou uma representação da realidade. A fotografia, assim como os textos, traz informações de um fragmento selecionado e organizado em virtude de intenções determinadas por um universo cultural, social e político.

A utilização da fotografia nas ciências históricas no inicio do século XX se fundamentava no paradigma de seu caráter de retratação exata da realidade, em que se presumia que as imagens seriam instrumentos que possibilitariam o registro real da história moderna. Todavia, a foto é em essência um inventário de informações de um determinado momento do passado, e seus conteúdos mostram assuntos congelados pelo instante fotográfico. Algo, aliás, que não impede em absoluto a procura de seus significados mais profundos de como se processam as manipulações em virtude das intenções por trás de sua criação. A comunicação, verbal ou não, ilude e confunde, devendo

7 AHPRP. Guia Arquivo Histórico de Ribeirão Preto. Ribeirão Preto (SP), 1996. 
sempre procurar perceber, numa atitude semelhante em relação às fontes textuais, o que está nas entrelinhas de cada imagem iconográfica:

A fotografia nos apresenta o visivel, mas nos remete ao imponderável dos fatos da vida histórica e social. (KOSSOY: 2014: 24)

No caso do recorte da dissertação, o advento da fotografia acompanha o grande desenvolvimento técnico da Revolução Industrial se situando no bojo de diversas transformações econômicas, sociais e culturais que as novas invenções da indústria vão imprimir a história moderna. Diante dessa situação, após Ribeirão Preto ser conectada aos trilhos da ferrovia, ligando-se portanto aos grandes centros Europeus onde ocorria uma grande inversão de capitais na produção de equipamentos e matérias fotossensíveis, a realidade da cidade será bastante retratada por imagens que, muitas vezes, reproduziam um discurso visual de uma nova urbe moderna e republicana.

A fotografia, nesse contexto, passa a possuir um papel fundamental enquanto possibilidade de informação e conhecimento. Podemos encontrar diversas imagens cuja representação da realidade se assemelha a ordem estabelecida pelos Códigos de Posturas, ou pelos discursos ufanistas dos intendentes municipais em relação ao progresso das obras urbanas e a transformação do antigo arraial numa cidade moderna. Contudo, diversas outras imagens retrataram as contradições daquela representação, mostrando outros usos de espaços privilegiados ou mesmo retratando a parte da cidade que deveria estar invisível ao cenário burguês.

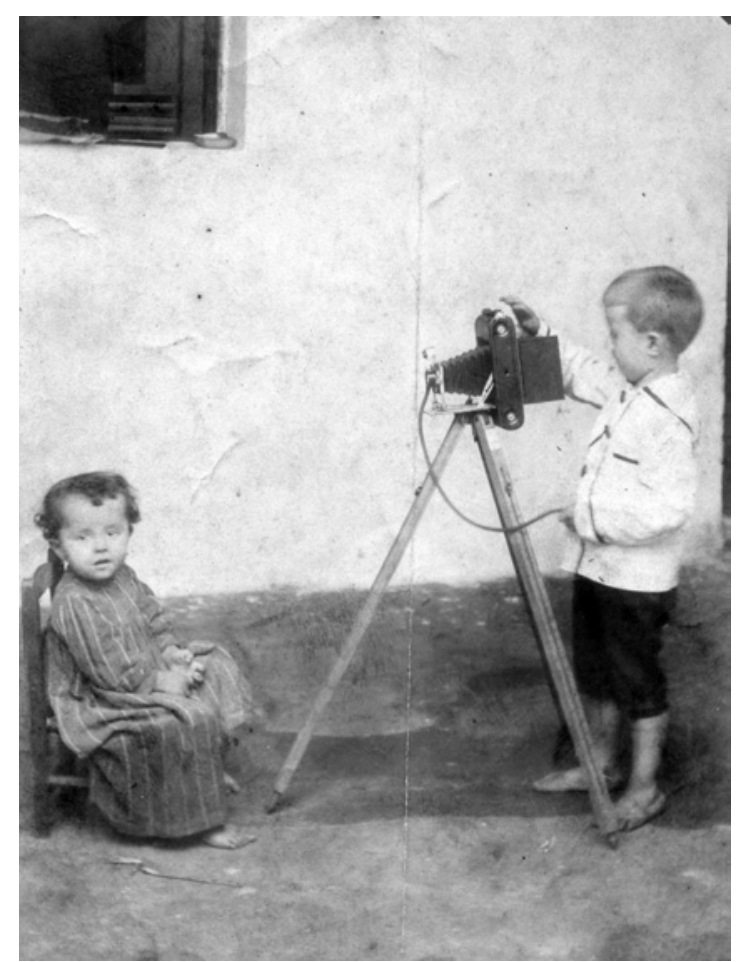

A expressão cultural dos povos exteriorizada através de seus costumes, habitação, monumentos, mitos e religiões, fatos sociais e politicos passou a ser gradativamente documentada pela Câmara. O registro das paisagens urbana e rural, a arquitetura das cidades, as obras de implantação das estradas de ferro, os conflitos armados e as expediçoes cientificas, a par dos convencionais retratos de estúdio - gênero que provocou a mais expressiva demanda que a fotografia conbeceu desde seu aparecimento e ao longo de toda a segunda metade do século XIX, são alguns dos temas solicitados aos fotógrafos do passado (KASSOY: 2014: 30)

Figura 2: crianças fotografadas em Ribeirão Preto. Fonte: APHRP.

\section{Capítulos}

No primeiro capítulo da dissertação procuramos situar brevemente os urbanistas em meio 
a política moderna brasileira durante a primeira metade do século XX. Para isso, partimos do problema levantado por Ângela de Castro Gomes (1998) sobre a dicotômica interpretação do dilema entre o público e o privado no Brasil. Segundo essa leitura, durante um período que vai desde o movimento municipalista dos anos de 1910 até a centralização tecnocrática dos anos de 1960, as instituições políticas brasileiras teriam balançado feito um pêndulo entre, de um lado o excesso de poder local e o domínio privado de oligarquias, e de outro, o abuso do poder público num arranjo de centralização estatal. Dessa maneira, procurando transpor essa divisão maniqueísta entre os dois polos sociais e institucionais, e partindo do pressuposto que ambos são permeados por vícios e virtudes, a intenção desse capítulo foi levantar alguns parâmetros de abordagem da penetração política de Saturnino de Brito e José de Oliveira Reis no sentido de escapar daquela dicotomia e averiguar o transito dos engenheiros em uma instituição municipal de poder.

Saturnino de Brito em sua trajetória profissional sempre preconizou nos seus planos urbanos uma posição centralizadora, com intervenção estatal contra o regime de laissez-faire característico do desenvolvimento das cidades brasileiras. Em seus relatórios aparecem críticas ao domínio de potentados locais que orbitavam as Câmaras Municipais em meio à ambígua presença de vereadores que eram ao mesmo tempo proprietários de terras, especuladores de terrenos e donos de empresas concessionárias de serviços urbanos. José de Oliveira Reis também enfrentará esse dilema ao longo de sua trajetória pela institucionalização do urbanismo nas administrações municipais brasileiras, tendo que lidar com a política local no âmbito, por exemplo, de Comissões de Plano de cidades.

No segundo capítulo abordamos a construção privilegiada da cidade intra-rios com as obras de melhoramentos e embelezamentos realizadas de forma prioritária no perímetro definido pelos canais do Retiro e Ribeirão Preto. A intenção foi ressaltar que a tubulação da rede d'água e esgoto também contribuiu para a consolidação desse espaço mais rico com a exclusividade do abastecimento doméstico ainda ao final do século XIX. A construção da rede também serve para a capitalização da Empresa de Água e Esgoto através do endividamento da Câmara Municipal, principalmente pela atuação de seu gerente Flávio de Mendonça Uchoa como procurador dos negócios da família Silva Prado em Ribeirão Preto.

Já nas primeiras décadas do século XX, todavia, se iniciam as crises de falta d'água, o que faz com que a Câmara Municipal instaure uma Comissão Especial entre os seus vereadores para tratar do assunto. Nesta ocasião Saturnino de Brito é convidado para elaborar o seu relatório sobre o abastecimento de água em Ribeirão Preto, deixando na cidade os elementos de sua teoria urbanística. O engenheiro é enfático quanto à possibilidade de se aumentar o volume de captação das águas de rios, o que permitiria a ampliação da rede de abastecimento para os bairros periféricos da cidade, como a Vila Tibério e o Barracão, desprivilegiados pelas obras de embelezamentos e melhoramentos mais circunscritas ao perímetro central.

Outro ponto essencial da urbanística de Brito apresentada na cidade foi a sua precursora visão ambientalista ao invocar a aplicação de Leis de Proteção de Mananciais. Legislação fundamental, segundo o engenheiro, para proteger os cursos d'água contra a atividade nociva, por exemplo, das 
grandes azendas de café que estabeleciam colônias de imigrantes nas margens de córregos, além de derrubar as suas matas ciliares para implantação de cafezais. Ao final, a despeito dos apontamentos de Brito, a administração dos serviços urbanos de águas, esgotos e energia se concentram em um monopólio exercido pala Empresa de Força e Luz de Ribeirão Preto. Algo que contrariava a concepção de Plano de Conjunto bastante defendida por Brito no que se refere à gestão urbana exercida pelo poder público.

O terceiro capítulo, por fim, remonta ao contexto histórico que envolve a passagem do urbanista José de Oliveira Reis por Ribeirão Preto. Portanto, nesse trecho se buscou levantar outros traços da ocupação da cidade na sua vertente sul, numa região mais alta em relação aos bairros operários desprivilegiados pelos construtores do município. Assim, ainda durante a Primeira República, este espaço situado entre a Praça XV de Novembro e a Avenida Nove de Julho é favorecido com a implantação de equipamentos salubres como grupos escolares, praças arborizadas e clubes de recreação, o que favorece a composição de uma região dotada de belos edifícios. Desse modo, quando José de Oliveira Reis é convidado pela Prefeitura Municipal para elaborar o seu Plano Diretor, já existia na década de 1940 uma oposição entre a zona norte, região baixa na vertente do Ribeirão Preto, ocupada por fábricas e moradias populares, e a zona sul, numa área mais alta, contrária aos ventos dominantes, que ia sendo progressivamente ocupada por famílias de classe alta.

Dessa maneira, procuramos abordar o diálogo do Plano Diretor de Oliveira Reis com o zoneamento social da cidade transparecido em leis, plantas e publicidade dos loteamentos na fronteira sul do município. O Plano procurou refrear o crescimento desorganizado da cidade propondo um zoneamento e o estabelecimento do limite da cidade, além disso ainda propunha uma ocupação mais harmônica dos leitos dos rios urbanos através da criação de parques lineares - os parkways. Todavia, a despeito das proposições do urbanista, se assiste na cidade o desenvolvimento de uma situação que agravou ainda mais as suas fronteiras sociais e o adensamento urbano em áreas de mananciais. 

Capítulo 1 



\subsection{Dois profissionais do urbanismo.}

Com o intuito de criar uma chave de entendimento que conecte os dois períodos de transformações urbanas do município de Ribeirão Preto recortados pela pesquisa. Sem perder de vista as particularidades históricas da cidade, procuramos situá-las através de uma abordagem historiográfica que abarcasse o dilema político das instituições brasileiras ao longo da primeira metade do século XX. Na linha de Marcus André B. C. de Melo (1993) essa abordagem pode ser feita tomando as ambiguidades da trajetória do municipalismo nesse período. Segundo o autor, o municipalismo se constituiu como uma das construções discursivo-programáticas mais antigas e resilientes da cultura política brasileira, adquirindo o status de "leito de procusto" de diferentes vertentes ideológicas nacionais. O municipalismo teria servido desde a crítica dos liberais à centralização imperial do Segundo Reinado, passando pela defesa por mais autonomia municipal durante a Primeira República, até chegar aos desdobramentos institucionais do Estado Novo e da redemocratização, quando a partir da criação de órgãos federais, como a ABM e o IBAM , o municipalismo se converte num instrumento de racionalização da moderna política no país.

O municipalismo, através da história brasileira, informou ideológica e pragmaticamente projetos fundamentais associados à modernização do país. De uma crítica à centralização política e à ausência de participação e representação, ele se associou à crítica autoritária-modernizante de cunho agrarista ao sistema sócio-político da República Velha que, no Estado Novo, enxergou no município o espaço plebiscitário e pré-político por excelência. Atingido o ange mobilizatório de sua trajetória durante a redemocratização do país na década de 40, o municipalismo se fissura em uma vertente política representada pela criação da $A B M$ e uma vertente tecnocrata associada ao IBAM. Na primeira dessas vertentes o municipalismo perde seu caráter militante e se transforma numa frente nacional de políticos provincianos. Na segunda, o municipalismo perde seu caráter militante e se transforma numa frente nacional de politicos provincianos. (MELO: 1993: 11).

Nesse sentido, como teria acontecido o movimento de institucionalização do urbanismo brasileiro nesse espectro dos dilemas entre a autonomia e a centralização das administrações municipais brasileiras? Nesse primeiro capítulo procuramos recortar algumas passagens históricas que envolveram os dois urbanistas escolhidos para o estudo no sentido de esclarecer suas posições no que toca a política nacional. Em outras palavras, qual foi o embasamento do republicanismo de Saturnino de Brito, expresso em cartas escritas a diferentes correspondentes? Algo que o fez pegar em armas para sustentar durante a Revolta da Armada a defesa do Governo de Floriano Peixoto na véspera da sucessão eleitoral? Do mesmo modo, o que teria alimentado o esforço de José de Oliveira Reis pela institucionalização do urbanismo brasileiro? Qual o sentido da elaboração de 
suas críticas e elogios aos prefeitos e interventores do Distrito Federal?

Como amplamente discutido na literatura especializada, a emergência do planejamento urbano enquanto campo de intervenção do Estado esteve, num primeiro momento, associada a intervenções urbanisticas de remodelação urbana e a ideologias estéticas e de bigiene em grandes cidades. Em um segundo momento, a estruturação desse campo de intervenção estatal está associada à questão da gestão urbana. De menor visibilidade, e talvez.por isso menos conhecida, a moderniżação da gestão constitui uma dimensão central da expansão da esfera pública - vale dižer, da construção do moderno Estado brasileiro. O projeto de modernização da gestão municipal tinha como paradigma histórico a reforma municipal americana da Progressive Era (1900-1912). O projeto de reforma de gestão nos EUA buscava isolar a burocracia dos governos locais da infuência das political machines. Entre suas principais inovaçoes está a criação de um executivo municipal técnico, o city manager - em lugar de um comitê de vereadores das machines. A reforma, portanto, buscava revolucionar a cultura politica americana do século XIX, dominada, como a brasileira, por forte clientelismo e patronagem. A reforma foi fundamental na construção da esfera pública e da "capacidade de Estado" nos EUA. O caso brasileiro se diferencia do americano, porque a reforma administrativa nos EUA teve mais sucesso nos niveis estadual e municipal do que no federal. O projeto do DASP, como assinalado, se restringiu, em larga medida, à área federal (MELO:1993: 10)

Ambos os engenheiros - Saturnino de Brito e José de Oliveira Reis - assumiram posições políticas que lidavam com esse moviemento pendular entre a cenralização fedral e o poder de oligarquias estaduais, como no caso do Partido Republicano Paulista, particularmente no apoio de Brito a candidatura de Prudente de Morais e, também no caso do Partido Democrático nos elogios de Oliveira Reis a família Prado. A sucessão presidencial de 1894 esteve ameaçada na ocasião, tanto por correntes que defendiam uma Ditadura Militar, quanto pela revolta monarquista da marinha que pretendia a restauração de Gabinetes desapossados com o advento da República. José de Oliveira Reis elogia Antônio Prado Junior pela contratação do urbanista Alfred Agache em 1928, durante a última gestão da Prefeitura do Distrito Federal nomeada por um presidente eleito pela máquina eleitoral da Política dos Governadores.

Os dois urbanistas, portanto, elaboraram suas propostas de intervenções urbanas diante de leituras conjecturais da situação política federal. Ambos procuraram estabelecer um planejamento urbano segundo suas concepções e ideologias políticas, o que possibilita tratar as suas peças urbanísticas como elementos para um enquadramento historiográfico do urbanismo. De acordo com Christian Topalov (1991), a possibilidade de se abordar o que se produziu em urbanismo numa perspectiva historiográfica parte da construção do contexto histórico dos urbanistas:

A cada época, os especialistas da cidade e do território podem, de fato, mobilizar sem risco uma terminologia de 'crise' para enunciar a urgência de uma 'questão urbana' (TOPALOV: 1991: 28)

Segundo Topalov (1991), a cidade já há um tempo se tornou objeto da ciência, o que não quer dizer que o espaço urbano tenha se desenvolvido tal e qual seus prognósticos científicos. Todavia, desde a segunda metade do século XVIII, para além de saberes parciais sobre sociedades urbanas, vem se desenvolvendo um instrumental científico que toma a cidade como um objeto global, ou como um sistema orgânico. Portanto, o City Survey inglês, ou urbanisme francês, além do urbanismo brasileiro, estariam marcados pela procura de meios para remediar uma desordem aparente aos urbanistas. A relação entre a apreensão do real e a projeção de sua transformação seria o elemento constitutivo da disciplina urbanística e justamente o que permite a constituição da historicidade de suas fronteiras e variáveis, ou do tempo e do espaço de seus paradigmas e 
instrumentos. Uma abordagem historiográfica dos planos urbanos permitiria uma identificação da aproximação entre ciência e ideologia, ou do lugar político e social dos urbanistas:

Um modelo de sociedade (...) não é arbitrário e não depende de uma pura história das ideias. Ele depende da história social de sua produção, de suas representações cientificas e, em particular, da história do próprio mundo da ciência em si e de suas relações com a sociedade. É com esta hipótese que retorno a "ciência da cidade" e que gostaria de ao mesmo tempo lembrar nossas origens, a fonte de todas as nossas alegrias e de todos os nossos problemas (TOPALOV: 1991: 30).

Os conceitos e a metodologia do planejamento urbano se constituíram como uma disciplina autônoma, e nesse percurso os fundadores do urbanismo se emanciparam de suas profissões de origem, as quais estavam subordinados por seus estatutos. Entretanto, essa emancipação não foi feita sem um desligamento estanque de suas formações originais, ou melhor, para esta nova disciplina não seria suficiente apenas uma legitimidade científica, mas também uma legitimidade social que será disputada pelos urbanistas numa aproximação a grupos dominantes ou dentro de instituições estatais. O urbanismo irá se afirmar dentro do escopo dos reformadores sociais que procuravam estabelecer uma ordem menos conflituosa e mais produtiva.

Como enquadrar, portanto, a relação entre lugar social, leituras de crise, planos de uma nova ordem espacial e o desdobramento histórico da cidade? O município de Ribeirão Preto se torna o laboratório para tais questões. Em poucas décadas a cidade sofreu grandes transformações sociais, econômicas e urbanas, partindo, ao final do século XIX, de uma economia de subsistência para a grande monocultura do café, e chegando ao meio do século XX a uma economia já bastante urbanizada e baseada num composto de indústria, comércio e serviços. Nesse período passariam pela cidade dois importantes personagens da história do urbanismo brasileiro. Quais as chaves de entendimento da política moderna brasileira que permitiria enxergar as leituras da cidade realizadas por aqueles dois urbanistas no momento em que enfrentaram os interesses de políticos locais?

Tomando como parâmetro Marcel Roncaylo (1988: 105):

la gestión urbana no depende exclusivamente de la autoridad municipal, sino que recibe de modo más o menos directo, coercitivo, impulsos del poder central, acaso sólo por médio de las leyes. La noción de política urbana reúne pues las opciones efectuadas por la autoridad local y las incitaciones y rechazos de las autoridades centrales, organizadas as veces estrategicamente.

Tal problemática, grosso modo, se associa ao nascimento do Estado Moderno num movimento de afirmação territorial e tutela burocrática sobre a cidade enquanto um corpo autônomo. O Estado nesse percurso não suprime em absoluto a organização municipal, mas a absorve como um elemento de sua capilaridade reduzindo o seu campo de ação através da regulamentação de suas normas de funcionamento. No Brasil, entretanto, existia a singularidade apontada por Victor Nunes Leal (2012) sobre o poder das oligarquias locais ainda como resquício do patriarcado sobre o qual se instaurou o novo arranjo institucional do Estado Republicano. Nesse movimento, as intituições políticas da Primeira República, num percurso já conhecido, arregimentaram o velho poder do latifúndio para constituir a representatividade e organizar a capilaridade do novo regime.

Chegamos, assim, ao ponto que nos parece nuclear para conceituação do "coronelismo": este sistema político é dominado por uma relação de compromisso entre o poder privado decadente e o poder público fortalecido.

O simples fato do compromisso presume certo gran de fraqueza de ambos os lados, também, 
portanto, do poser público. Mas, na Primeira República - quando o termo "coronelismo" se incorporou ao vocabulário corrente para designar as particularidades da nossa politica do interior -, o aparelhamento do Estado já se achava suficientemente desenvolvido, salvo em casos esporádicos, para conter qualquer rebeldia do poder privado. É preciso, pois, descobrir a espécie de debilidade que forçou o poder público a estabelecer o compromisso "coronelista” (LEAL: 2012: 252).

No âmbito da história do urbanismo, Roncayolo (1988) lembra um movimento de leis que procuraram organizar o poder municipal, criando um jogo institucional de novas responsabilidades e prerrogativas, como: a Poor Law, na Inglaterra, designando a figura de um executivo municipal, o Bürgmeister na Alemanha, criando um agente administrativo nomeado por um conselho, ou o manager nos EUA para governar as pequenas cidades. As instituições municipais tornam-se locos de diversas ações públicas geridas pelos Estados Nacionais e a sua função se multiplica acompanhando o aumento de responsabilidades relacionadas a serviços como água, gás, eletricidade, transportes, educação e medidas de controle e regulação sanitária.

Diante desse fenômeno, como teria ocorrido o trânsito político e institucional dos planos urbanos elaborados por Saturnino de Brito e José de Oliveira Reis para a Câmara Municipal de Ribeirão Preto? Como tais urbanistas circularam numa instituição local de poder frente ao dilema e as nuances da política moderna brasileira? Para abordar tais questões em vista da defesa pela centralização política de Saturnino de Brito e do trabalho institucional de José de Oliveira Reis, procuramos escapar da interpretação maniqueísta que justificou ao longo desse período ou o enfraquecimento do poder central, com o aumento da autonomia dos municípios, ou a atenuação do poder local, num movimento de centralização.

\subsection{A política moderna brasileira.}

Ângela de Castro Gomes (1998) define o dilema da política moderna brasileira retomando uma imagem dicotômica retirada do texto "Política e Letras", do crítico literário Alceu de Amoroso Lima, o Tristão de Athayde. Segundo esta imagem, ao longo da primeira metade do século XX, da Primeira República (1889-1930) à Ditadura Militar (1964), passando pelo Estado Novo (19371945) e pelo Período Democrático (1945-1964), o domínio das instituições políticas brasileiras teria balançado feito um pêndulo entre a autonomia municipal - domínio do poder privado - e a centralização federal - domínio do poder público.

Esse movimento institucional teria ocorrido, segundo a autora, em virtude de uma série de interpretações da realidade brasileira feitas numa chave dicotômica, opondo de maneira maniqueísta o bem público (poder central) do mal privado (poder local). Tais interpretações de ideólogos clássicos do $\mathrm{Brasil}^{8}$ embasaram aquela oscilação através de projeções da falsa solução pela eliminação de um dos dois pólos de poder. Essas interpretações dicotômicas teriam se reproduzido desde o municipalismo de Tavares Bastos, nos anos 10, até a defesa de uma centralização tecnocrata, nos anos 60, por Golbery de Couto e Silva.

8 Como, por exemplo, Oliveira Viana em Populações meridionais do Brasil. Brasília: Senado Federal, Conselho Editorial, 2005. 
A ideia de que os governos deslizam para artificialismos políticos teria justificado todas essas mudanças institucionais dos regimes políticos da primeira metade do século XX. O resultado na politica nacional foi eterno conflito entre duas forças sociais: o "cesarismo" e o "caudilhismo", ou melhor, a longa disputa na história política brasileira entre a centralização por esferas federais contra a autonomia municipal. Segundo Tristão de Athayde, estaria aí a dicotomia e o impasse da modernização política do país.

Durante a Primeira República este dilema esteve encarnado na figura de Rui Barbosa e Pinheiro Machado. Rui Barbosa, como a imagem do homem inteligente, respeitadíssimo, mas que nunca obteve sucesso eleitoral, sendo uma espécie de paradigma do republicanismo teórico, admirado porém sem maquina eleitoral. Já Pinheiro Machado era o signo dos compromissos de caudilhos em meio às oligarquias estaduais, um homem que fazia os presidentes, notado mais pelas exímias capacidades de articulador político do que por suas explanações teóricas, sendo o símbolo do domínio político local sob o qual a Política dos Governadores teria construído a sua capilaridade.

O Drama da República, conforme Alceu Amoroso Lima quer demonstrar, e numerosos outrospensadores seus contemporâneos e sucessores endossaram, era o de estar caracterizada por uma tensão, ao mesmo tempo constitutiva da politica nacional e desintegradoura de suas possibilidades de desenvolvimento nos marcos da modernidade ocidental. Ou seja, ela se situava na fronteira entre o público e o privado, sendo essa a sua principal marca e também o seu dilema, pois, como o texto magistralmente indica, o Brasil não era Rui ou Pinheiro, era Rui e Pinheiro (GOMES: 1998: 496).

A tragédia das instituições políticas brasileiras que a imagem remete constituiu o dilema da política nacional. Segundo Gomes (1998), essa situação se desdobra de outras formas e com outras faces ao longo de quase todo o século XX. Aquela leitura da realidade brasileira se constitui como o impasse de um processo de modernização que necessitava sempre ser disparado pela esfera estatal no sentido de atenuar o poder de oligarquias arraigadas ao domínio local.

O grande desafio a ser enfrentado pelas nacões coloniais e "atrasadas" como o Brasil, envolvia duas premissas. De um lado, o reconhecimento de um certo paradigma de política moderna, entendida como o mundo dos cidadãos racionais e dos procedimentos públicos impessoais, mundo existente de fato nos paises desenvolvidos. De outro lado, a necessidade de compreensão de uma realidade social que com ele se confrontava, pois se fundava em padrões de autoridade tradicionais - personalizada e emocional - que não podiam ser ignorados e menosprezados, sob a pena de total insucesso. (GOMES: 1998: 499)

$\mathrm{Na}$ raiz do diagnóstico estaria um conjunto de oposições: de um lado, o país representado pela sociedade rural exportadora, domínio descentralizado do poder patriarcal, clientelista e oligárquico, e de outro lado, um país otiundo de uma sociedade urbano-industrial, com raízes no poder centralizado do Estado, sob bases impessoais e racionais de uma burocracia técnica. Essa interpretação dualista da formação social brasileira seria a responsável pela avaliação dos males advindo da falta de poder público e sobra de poder privado, emperrando uma reflexão dialética em que ambos os lados estariam penetrados por vícios e virtudes.

As instituições políticas brasileiras não escaparam dessa ambiguidade e a modernização do país patinou na falsa solução da eliminação de um dos pólos. Na década 1930, durante o Estado Novo, sob a mesma leitura se promove uma inversão, contra o excesso de poder privado ataca-se o paradigma do Brasil liberal, e a arquitetura institucional de partidos e do parlamento são desmontados 
por um arranjo ideológico autoritário montado sobre a figura personalista de um antigo caudilho. A perversão da máquina oligárquica da Política dos Governadores durante a Primeira República teria levado ao ataque ao indivíduo cidadão, elemento da soberania do voto, num afloramento de correntes políticas e intelectuais que tomaram por base uma real impossibilidade de adaptação no Brasil do modelo de Estado Liberal.

Os ideais da autoridade racional-legal e da economia urbano-industrial são mantidos como signos de uma sociedade moderna, porém os instrumentos operacionais e as instituições políticas da materialização daquele projeto de modernização sofrem mudanças substanciais e a arquitetura liberal defendida por Rui Barbosa é colocada abaixo. A ideia de uma equidade do individuo cidadão, portador de voto e opinião, passa a ser contestada por uma suposição da desigualdade natural dos seres humanos que não poderiam ser tratados da mesma forma perante a lei. As críticas acentuavam a importância da criação e fortalecimento de instituições estatais - órgãos e políticas públicas como o mecanismo para o estabelecimento da modernidade no país.

Um dos mentores da proposta de um Estado autoritário e corporativo, Oliveira Vianna, publica em as Populações meridionais do Brasil as causas do "atraso" político do "Brasil real" como o domínio do poder privado. A sociedade brasileira formada pelo ruralismo e pelo escravismo teria gerado um padrão de sociabilidade centrado na família e na autoridade pessoal do grande proprietário. Esta herança do domínio rural - o seu espírito de clã - emperrava segundo Vianna o desenvolvimento moderno brasileiro, pois qualquer associação que escapasse a família era tolhida. A falta de autoridade estatal sobre esse ambiente não teria gerado o espírito corporativo característico do ambiente urbano, para enfrentar essas tendências de sociabilidades enraizadas na terra era importante o poder central, metropolitano ou nacional, que agisse pelo desenvolvimento e pela proteção dos cidadãos. Uma inversão do Absolutismo como o único meio de construção de um Estado Moderno orientado por procedimentos racionais e burocráticos.

Após os anos de 1930, encerrando a breve abertura da Constituição de 1934, tendo reprimido ambos os lados de movimentos radicais - do PCB à Ação Integralista - o grupo em torno de Getúlio Vargas amadurece, com o apoio de forças militares e o respaldo de concepções políticas e ideológicas, uma proposta de Estado autoritário e corporativo com base na personificação da figura política do chefe de Estado. A fórmula política dos ideólogos do Estado Novo, novamente numa chave dicotômica, possuía o intuito de combater os artificialismos políticos da Primeira República. A premissa era desmanchar a arquitetura institucional republicana baseada na separação de poderes com a criação de um Estado forte e "democrático" mediante a revitalização do sistema presidencial de governo. O Estado seria um órgão de coordenação, direção e iniciativa da vida política, funcionando como instrumento estratégico da lei, da justiça e do desenvolvimento econômico e social.

A nova democracia se fundaria numa negativa da sociedade baseada em dissensos e o Estado seria o organismo da unidade em diversos níveis institucionais, econômicos, sociais e políticos. Esse arranjo se assentaria em representações de bases diversas para a consolidação de um 
Estado Moderno e nacionalista, sua capilaridade estaria nas especializações técnicas, com a criação de órgãos, departamentos e institutos que possuiriam o objetivo de absorver demandas sociais. Tais repartições seriam os novos meandros de um Estado corporativo baseado em sindicatos, conselhos técnicos, autarquias e toda uma estrutura burocrática e profissional.

Projeto corporativo e fortalecimento do sistema presidencial de governo eram as duas pedras de toque de um ideal de modernização política brasileira que reinventaria as fronteiras da dicotomia entre público e privado, promovendo "combinatórias" sofisticadas e plenas de ambiguidades. A complexa dinâmica dessa proposta iria deitar raizes na "realidade nacional", conseguindo produzir simbolos e ideias que alcançaram um amplo compartilhamento junto à população e deixaram marcas profundas e duradouras na vida politica do país (GOMES: 1998: 518)

O urbanismo como um instrumento científico de controle das cidades entraria como uma das peças de estruturação de um Estado corporativo. A sua institucionalização em esferas da administração pública se intensifica na Era Vargas acompanhando uma nova realidade urbanoindustrial que demandava uma reconstrução de saberes e práticas urbanísticas nas cidades brasileiras. Se no complexo processo de mudanças históricas, ideias e eventos sociais estão mutuamente emaranhados, podemos afirmar que na década de 1930 o novo estágio da realidade urbano-industrial força a "reconstrução" de saberes e de práticas urbanisticas instaladas nas cidades brasileiras. Ao longo da década, as mudanças profundas no âmbito da economia, da política, da organização social, da administração pública, do desenvolvimento urbano terão um correspondente no campo do urbanismo (FELDMAN: 2010; 51)

Algo que já vinha sendo defendido por Saturnino de Brito em grande parte dos seus relatórios técnicos elaborados desde o início da Primeira República. A tônica dos argumentos políticos desse engenheiro sempre foi a de que as reformas sanitárias fossem realizadas sob a tutela de comissões estaduais de saneamento para que os planos não se fragmentassem sob ação perniciosa de oligarquias locais e fossem executados em seu conjunto abarcando a totalidade da cidade.

Não exatamente como advertia Saturnino de Brtio, entretanto, a reestruturação da administração pública realizada por Getúlio Vargas terá correspondência no âmbito do urbanismo. Assim, novas instituições são criadas nesse processo de reaparelhamento estatal como no caso das Comissões de Planos ou Departamento de Urbanismos vinculadas às administrações municipais, que irão envolver diversos profissionais num trabalho de assistência técnica, não só das capitais de estados, mas também dos municípios do interior do país.

Sarah Feldman (2005) exemplicafica esse movimento que se cristaliza no pensamento do professor da disciplina de urbanismo da Escola Politécnica de São Paulo, Luís Inácio de Anhaia Mello. Segundo a autora, desde os anos 30 a teoria administrativa brasileira possuía o modelo de organização norte americana, porém especificamente em 1938 ocorre um forte movimento de centralização do serviço público com a criação do Dasp - Departamento Administrativo do Serviço Público - que sob influência das Comissões de Eficência do gorverno Hoover, passaria por agências locais para operar também nos estados e municípios.

As ideias defendidas por Anhaia Mello se inscrevem nesse movimento mais amplo de modernização da administração pública no Brasil. Desde o final dos anos de 1920 já defendia a organzação americana para a gestão municipal, em geral, e para as questões de urbanismo, em particular, como veremos adiante. A ideia de desvincular as questões de urbanismo da política já está presente em seus textos do 
anos de 1920 e 1930, quando defende a Comissão do Plano como orgão por excelência para as questões de urbanismo. Mas os principios da organização do Departamento de Urbanismo contidos no DecretoLei 431 estão explicitados em dois textos escritos nos anos de 1940 (FELDMAN: 2005: 48)

Todavia, ao final do Estado Novo se assiste um novo movimento descentralizante promovido pela carta constitucional de 1946. A presença de um orgão federal em instâncias locais é inviabilizada pela campanha municipalista e aquele projeto modernizador será recoloccado sob a tutela do município. Dessa maneira, os primeiros orgão públicos particularmente pensados como o setor de urbanismo estarão sob a esfera das intituições municipais. Diante disso, Feldman (2005) destaca como característica desse início a não efetividade dos Planos Urbanos que acabaram marcados como "plano-discurso". Porém, com o passar dos anos e a consolidação cada vez maior das instituições de urbanismo se verá a penetração dessa disciplina em esferas da administração pública, o que não acontecerá sem tensões e conflitos sociais, particularmente, entre os profissionais urbanistas e grupos dominantes ou as camadas populares atingidas pelas reformas.

nas primeiras décadas do século, os planos refletiam as condições de liderança das elites, com o urbano, para executar obras de seu interesse, atendendo as partes da cidade que lhes interessavam, e atendendo às necessidades de abrirfrentes para os interesses imobiliários. Posteriormente, os planos, por abordarem 'mais problemas do que nossas elites sentiam, queriam e podiam resolver', passam a se configurar unicamente como discurso (FELDMAN, 2005: 23)

Nesse contexto nacional de inflexão do pensamento urbanístico, Rodrigo Faria (2007) pincela a trajetória de José de Oliveira Reis irá atravessar como funcionário do urbanismo no Rio de Janeiro justamente o período do pêndulo em que movimento de centralização getulista será desmanchado com a constituição de 1946. Oliveira Reis, portanto, dentro da disputa política pela construção institucional dos setores de urbanismo nas administrações municipais brasileiras, se torna um dos protagonistas no processo em que a disciplina deixa de ser um campo de formação complementar para se tornar um campo profissional singular.

Dessa maneira, segundo aquela abordagem levantada por Ângela de Castro Gomes (1998), qual teria sido o percurso de Saturnino de Brito e José de Oliveira Reis no drama da política moderna brasileira? Quais teriam sido os dilemas enfrentados no âmbito de uma administração municipal brasileira? Primeiro por Brito, ao ser contratado para incorporar os trabalhos da Comissão sobre Abastecimento d’Água da Câmara Municipal de Ribeirão Preto em 1912, e posteriormente por José de Oliveira Reis quando é convidado em 1945 para elaborar o Plano Diretor da cidade, além de colaborar com os trabalhos da Comissão Especial do Plano do município.

Christian Topalov (1991) aponta que quando o objeto e a prática desses profissionais do urbanismo abrangem a cidade como uma totalidade, a aplicação de seus Planos Urbanos de forma integral acaba em choque com interesses particulares sobre o domínio de uma territorialidade:

Mesmo que a maior parte deles seja prudente na delimitação de suas estratégias cognitivas, em função dos limites fixados pelas demandas de sua base social, eles são inevitavelmente conduridos a entrar em conflito com certos interesses em jogo, inclusive os econômicos - por exemplo, uma parte dos proprietários imobiliários rentistas ou as companbias de serviços urbanos (TOPALOV: 1991: 30).

Desse modo, quais seriam as vicissitudes desse processo de institucionalização do urbanismo frente à administração municipal de Ribeirão Preto como o lócus das ambiguidades do 
processo de modernização nacional? A relação entre estes novos especialistas do espaço urbano e a tutela institucional da cidade ocorreu numa oscilação entre a autonomia dos profissionais com uma posição crítica aos poderes locais instituídos e ao desenvolvimento desorganizado da cidade, e a apropriação pelos políticos locais de fragmentos dos planos e relatórios dos urbanistas, dotando decisões enviesadas pelos interesses oligárquicos com as etiquetas e carimbos de credibilidade que os nomes dos urbanistas conferiam.

\subsection{Plano de Conjunto contra o domínio patriarcal?}

No âmbito da defesa dos Planos de Conjunto, Saturnino de Brito sistematiza os aspectos políticos de seu urbanismo no segundo capitulo do livro Notes sur le tracé sanitaire de villes, cuja tradução seria Competência administrativa e técnica para organiżar e executar os planos de conjuntos - legislação necessária. Neste capítulo, Brito irá explicitar a preconização da intervenção estatal contra o regime de laissez-faire característico do desenvolvimento das cidades. Sob esse regime de liberalidade, segundo o urbanista, o crescimento da cidade era ditado pelos interesses particulares dos especuladores de terrenos e dos empreendedores imobiliários. As suas críticas visavam, portanto, atacar os interesses citadinos locais de proprietários de terras ou promotores imobiliários que gravitavam em torno das Câmaras Municipais do interior do país.

A posição de Brito além de claramente intervencionista, era também centralizadora e em certo sentido antidemocrática na medida em que as eleições eram dominadas pelos cacifes políticos locais. Naquele segundo capítulo de notes sur le tracé Sanitaire des Villes, o engenheiro chega a afirmar que "o administrador municipal eleito é sempre e em todo lugar um comandante que obedece aos desejos daqueles que ele é designado comandar: os grandes eleitores". (BRITO apud ANDRADE: 1992: 231). Ou seja, Brito se referia ao fato das eleições, durante a Primeira República, estarem determinadas pelo voto de cabresto, estabelecendo uma situação de compromisso entre os Intendentes/Prefeitos e a representação dos interesses de potentados locais pelos vereadores das Câmaras Municipais.

Desse modo, Brito expressa sua posição contrária à incompetência dos poderes locais para executar os Planos de Conjunto, o saneamento e a aplicação das leis que assegurassem a higiene pública das cidades. Precavido de que não bastaria a elaboração do Plano Urbanístico para a sua implementação, ele discorre sobre a legislação como um meio de garantir o desenvolvimento orgânico das cidades, neutralizando a má influência de oligarquias locais para assegurar o interesse coletivo e a segurança pública. A legislação deveria, assim:

a) Estabelecer um programa para os estudos dos planos de conjunto para a formação, a extensão e o saneamento (água potável, esgotos, transformação dos quarteirões insalubres, etc.) das cidades, e para sua realização prática;

b) Tonar obrigatório esses estudos e a execução progressiva dos planos aprovados:

c) Designar os poderes competentes para fazer realizar esses estudos, para os aprovar ou modificar e para executar os projetos, determinar os prazos para revisão dos planos e o caminho a seguir nesse caso; d) Garantir a execução dos projetos (extensão das cidades, água potável, esgotos, transformação dos quarteirões insalubres, etc.), conciliando os interesses dos proprietários e os interesses públicos e 
descartando as intervenções prejudiciais dos governados e dos governantes (BRITO: 1944: 72 apud ANDRADE: 1992: 232)

Muito dessas concepções sobre legislação urbana são formuladas durante os embates que Brito travava com os interesses locais, como por exemplo, ao realizar os seus trabalhos em Santos, por volta de 1905. Mais tarde, ele as sistematiza no Le Tracé, momento em que faz referência ao livro de M. Eug. Couturaud, Guide Pratique pour la Reconstruction, l'Extension, l'Aménageement et l'Embellissement des Villes, de onde extraí as diretrizes da Loi Cornudet, aprovada na França, no dia 1 de junho de 1915, e que passa a regulamentar os planos de ordenação, embelezamento e extensão das cidades francesas. Ao transcrever integralmente a lei, Brito procura demonstrar a sua filiação a tradição intervencionista e centralizadora do Estado francês no que tange a legislação urbanística.

A lei, regulamentando a marcha administrativa das expropriacõos do ponto de vista moderno saneamento, crescimento, embelezamento, etc. - deve estabelecer a fórmula prática e equitativa para conciliar o interesse publico (expropriação a longo prazo) e o interesse imediato dos proprietários, mas ela deve também afastar as perturbações provenientes da intervenção da politica local e dos especuladores de terrenos e de imóveis (BRITO: 1944: 87 apud ANDRADE: 1992: 234)

Durante a trajetória profissional de Saturnino de Brito irá aparecer em diversas palestras, relatórios e planos essa defesa pelos Planos de Conjunto contra o domínio patriarcal dos municípios. Seu discurso no Congresso de Prefeitos Municipais de Pernambuco em 1916 dirá o seguinte:

É de vantagem que os mais importantes serviços municipais sejam compreendidos em um programa geral, racionalmente organizado, de modo a se estabelecer a harmonia entre os elementos e a se garantir a continuidade na execução, independentemente das competiçoes politicas locais e dos interesses pessoais. O programa geral da administração municipal será completado pelos planos de conjunto relativos aos grupos de serviços distintos. (BRITO: 1944: 161)

Em virtude de seu positivismo, Brito preconizará a administração centralizada, principalmente sob o nível estatal. Essas posições políticas possuíam relação com os seus laços de parentesco, além de sua formação como engenheiro politécnico e a sua trajetória política e profissional pelo interior do país. Oriundo de uma oligarquia que procurara se modernizar, Brito nasceu em 1864 na Fazenda Velha, freguesia de São Gonçalo pertencente ao município de Campos no vale do Paraíba fluminense. O seu pai, que não chegou a concluir o curso de engenharia em Portugal, se tornara um próspero fazendeiro que ao final da década de 1880 enviara seu filho a Escola Politécnica do Rio de Janeiro, aonde, aos 17 anos, este iria escrever os seus primeiros flertes filosóficos com as obras de Montesquieu, Descartes e Augusto Comte.

Em a “Teoria Lógica da Assimilação" Brito demonstra o inicio de sua filiação ao Positivismo e a sua crença num movimento pela ordem como algo transformador da realidade social:

Já não são, as leis sociológicas, leis imutáveis em sua permanência constante com as leis cosmológicas, urge convergir todos os esforços para conseguir sobre o espirito público a unidade de pensamento, dar-lhe a força que faça a nova lei de ordem, para, desenvolvendo-a progredir moral, filosófica e politicamente (ALVARENGA: 1979: 25-27).

Após a formatura na Escola Politécnica, por influência na Corte do Conselheiro Tomás José Coelho de Almeida, que havia fundado o Colégio Militar no município de Campos, Saturnino de Brito parte para uma série de trabalhos entre 1888 a 1892 na construção de estradas ferroviárias em 
estados do Nordeste, passando pelo Ceará, Bahia, Sergipe, Pernambuco e Rio Grande do Norte. A partir de então Brito começa a escrever seus relatórios que ficaram conhecidos por extrapolarem os limites estritamente técnicos dos problemas urbanos e sociais que abordava.

No relatório sobre o prolongamento da Estrada de Ferro de Baturité se vê sua leitura do comportamento humano ao atravessar o Sertão do Cariri no Ceará:

É pobre a zona atravessada [e] sofrendo atrozmente em cada seca [se vê] trabalhadores tornados cada vez mais indolentes pela perda acumulada de esperanças (...). Penso mesmo que os resultados duplamente negativos decorrentes do desfavor com que são tratados por uma providência rancorosa e injusta, a qual atribuem a inconstância das estações, e os resultados surpreendentes ocasionados pela favor largamente dispensado nos bons invernos, tornaram o trabalhador cearense muito diferente do homem de lavoura do Sul, onde o trabalho é assíduo durante o curso completo do ano e onde pouco tempo sobra para efusões preguicosas (BRITO; 1944:206)

Ao voltar do Nordeste, Brito encerra suas atividades como engenheiro ferroviário e após um contrato com a Câmara Municipal de Piracicaba, onde residia o político constituinte paulista Prudente de Morais, inicia o levantamento topográfico da cidade para a instalação de uma rede de esgotos, inaugurando sua série de trabalhos referentes à engenharia sanitária. Entretanto, essa etapa é interrompida pelo seu alistamento em defesa ao governo de Marechal Floriano Peixoto, que estava sendo atacado durante o ano de 1893 por tentativas de restauração monarquistas de setores descontentes da Marinha que haviam perdido gabinetes de Estado com o advento do governo republicano. Brito irá servir como chefe de peça de artilharia em defesa da barra da Baía de Guanabara contra o fogo do encouraçado revoltoso Aquidaban.

Gomes (2002) descreve os primeiros anos da República como um período marcado por muitas disputas políticas, em que não se opunham apenas monarquistas e republicanos, como no caso da Revolta da Armada, mas também os próprios republicanos que se dividiam entre o novo desenho institucional e o funcionamento do regime.

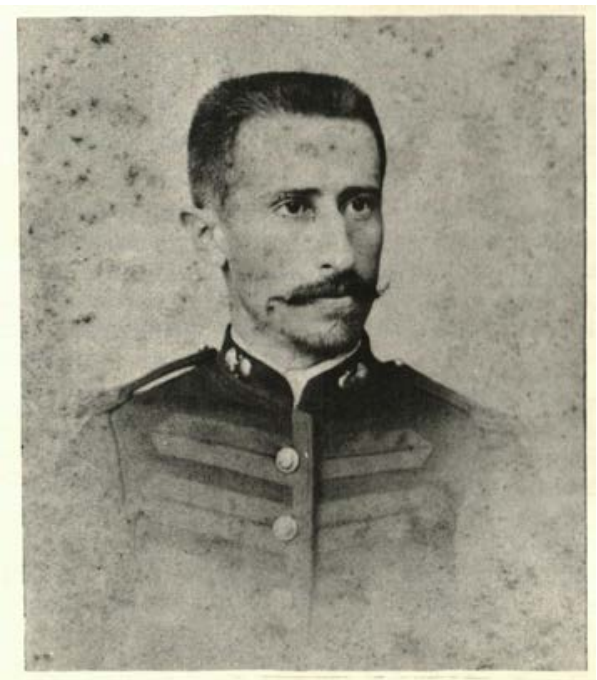

Saturnino de Brito como voluntário do Batalhão Benjamin Constant, na rebelião de 1893. Figura 3. Fonte: (ALVARENGA, 1979) Castro (2002) irá dizer que uma vez assentada à poeira do golpe militar de 1889, o Decreto no 1, que instituía um Governo Provisório, encarregava o governo de Marechal Deodoro das medidas políticas administrativas necessárias à conclusão da Assembleia Constituinte. A composição dos políticos da Assembleia dos Estados Unidos do Brasil iria aumentar as correntes que se arregimentavam em torno das proposições federalistas, aumentando a autonomia política das antigas províncias e municípios:

Com a nova designação Estados Unidos do Brasil, caía por terra uma longa experiência politicoinstitucional advinda do Império, cuja base era a crença na ação salvadora do poder central como agente da ordem e protetor da liberdade da população contra a ação dos poderes locais (...). Grupos políticos de diferentes regiões, notadamente do Centro-Sul, passaram a considerar o poder central monárquico o principal responsável pelo estrangulamento econômico e político do país. Consequentemente, viam nas proposições federalistas a fórmula ideal para se afastar daquele sócio dispendioso e autoritário 


\title{
(CASTRO: 2002: 35).
}

Os membros da Constituinte se dividiam, segundo Castro (2002), em três correntes. A primeira dos deputados ligados ao Governo Provisório, que tinham como principal porta-voz Rui Barbosa, e defendiam a existência de um poder central com importantes atribuições, sendo por isso denominada de "unionistas". Já o segundo grupo radicalizava a ideia de descentralização, restringindo o poder central em proveito da proeminência dos estados. O líder dessa bancada era o gaúcho Júlio de Castilhos, tendo ao seu redor diversos políticos positivistas que haviam integrado os movimentos abolicionistas e republicanos, também fervorosos defensores do Estado laico. Por fim, o terceiro grupo, que atuou na mediação entre os unionistas e os ultrafederalistas, possuía lideranças políticas regionais como Prudente de Morais, que presidia a Assembleia, sendo o grupo que acaba encaminhando os embates na confecção de um texto constitucional de composição, com destacada atuação desses parlamentares moderados do terceiro grupo que se reuniram em torno dos políticos paulistas.

No início de 1894 quando Saturnino de Brito dá baixa do combate contra a Revolta da Armada e se retira do Batalhão Benjamin Constant, ele deixa duas cartas em que se entreveem as suas orientações políticas e sociológicas naquele momento de consolidação da Primeira República. Na primeira carta, com um tom de posição pública, Brito alega que seu alistamento num dos batalhões patrióticos que se formaram em defesa do governo de Floriano Peixoto se fazia pela garantia da aplicação da nova Constituição Federal elaborada em 1891. A fim de consolidar o regime republicano, então com três anos de existência, Brito advoga pela formação de um governo civil presidido por Prudente de Moraes, um dos deputados republicanos paulistas que, junto a Campos Sales, lideraram a mediação dos embates entre os "unionistas" e os "ultrafederalistas" na Assembleia Constituinte.

\begin{abstract}
Todos sabem como o Sr. Prudente de Morais cooperou para que em um meio político tão heterogêneo se conseguisse a votação da nossa Constituição. Todos admiraram como em uma assembleia que lembrava a arca de Noé (expressão feliz de um velho e honrado patriota, o Sr. Teixeira de Mello), onde a extravagância dos nomes acentuava concretamente a extravagância das opiniões, todos admiraram como em tal meio a vontade calma, refletida e enérgica do Sr. Prudente de Moraes conseguiu o respeito e a obediência aos reclamos dos interesses da Pátria. Daí resultou que o nome do digno patriota surgisse como o único capaz de fazer frente à candidatura do General Deodoro. Receava-se então o predomínio da influência militar, quando o bábito de mando autoritário já estava servindo de bastidor aos ministros, permitindo que, enquanto gozassem da confianç suprema, eles e seus amigos a explorassem torpemente em proveito próprio (BRITO: 1944: 24)
\end{abstract}

Segundo José Murilo de Carvalho (1989), durante a proclamação da República, o Rio de Janeiro - de onde Brito escrevia suas cartas - havia se tornado a arena dos destinos nacionais em jogo: o cenário de greves, fechamentos de jornais e de uma revolta de quartel. Durante o governo de Floriano Peixoto, diante das clivagens e posicionamentos de diversas classes sociais, os presidentes militares, numa tentativa de tomar as rédeas da situação, promovem de maneira violenta deportações e encarceramentos de elementos que promoviam os conflitos, expulsando estrangeiros acusados de anarquismo, e encarcerando populares, como capoeiras, na Casa de Detenção. A campanha de Saturnino de Brito pela eleição presidencial do republicano paulista Prudente de Morais se fazia, 
portanto, pelo intuito de se assegurar uma transição política que respeitasse a Constituição Federal, mas que também garantisse que o poder do regime não se dispersasse pelas oligarquias locais:

\section{Eleição Presidencial \\ Carta dirigida a amigos e bons republicanos \\ Rio de Janeiro, 20 de fevereiro de 1894}

Entre os diversos candidatos que se apresentam ou que são apresentados, salienta-se o Sr. Prudente José de Moraes Barros. Atendendo a que o momento atual, quer nas trincheiras, quer nas urnas eleitorais, é de ação e não de discursos, permitimo-nos a liberdade de nos dispensarmos de quaisquer referenciais aos candidatos que são indicados por grupos em minoria, uns consultando simpatias individuais de chefes politicos das localidades, outros insinuando nomes com o fim claro de explorarem a tola ingenuidade de muitos eleitores e, assim, fazendo crer que existe no eleitorado grande divergência de sentimentos e de desejos. Tal divergência seria meramente fictícia e tanto maior se acusaria quanto maior o numero de candidatos, pois que o compadresco politiqueiro teria então objetivos vários a atender (BRITO: 1944: 22).

$\mathrm{Na}$ segunda carta de Saturnino de Brito, aparecem suas reflexões mais particulares, oriundas de sua correspondência com um amigo ou parente, em que expõe suas ideias sociais e políticas filiadas ao Positivismo. Se na primeira carta declara apoio à eleição de Prudente de Morais, nesta segunda ele demonstra ceticismo quanto ao sistema eleitoral. Tal incredulidade a respeito da democracia tem origem em sua crença na doutrina de Auguste Comte, segundo a qual o desenvolvimento ou a evolução política e social estariam previstas em etapas. Desse modo, transparece que o apoio de Brito a eleição presidencial era apenas conjectural, pois ele não era avesso à ideia da implantação de uma Ditadura Republicana como etapa necessária a um período de transição que conciliaria liberdade com autoridade. A partir desse raciocínio evolutivo, Brito se isenta da incoerência do fato dele próprio não ser um eleitor naquele momento da Revolta da Armada, mas ainda assim aconselhar os eleitores a votarem no candidato Prudente de Morais.

Em 1893, com a esquadra revoltosa ameaçando a Capital Federal, Brito considerava importante que todos os republicanos, dos democratas aos ditatorialistas, se reunissem em torno da defesa da Constituição Federal de 1891. A salvação do país estaria na salvaguarda da suprema lei, defendida neste momento por uma união desinteressada dos republicanos. A sua preocupação essencial, portanto, era assegurar o dispositivo constitucional da eleição presidencial posto em questão pela Revolta. Brito se eximia das ambiguidades mais profundas em se alinhar aos partidos políticos daquele momento, não se ocupando das eleições de deputados e senadores.

Assim poderás melhor ajuizar do que sou em política, não me prendendo a partidos e sim a princípios
e só tributando o men fraco apoio aos indivíduos para realização de atos que francamente interessem à
garantia da ordem material e da liberdade espiritual em nossa Pátria (...) o momento excepcional em
nossa vida politica, reclama a aplicação de esforços sinérgicos, tanto nos pontos de combate como nas
urnas para satisfacão do dispositivo constitucional em questão (...) ao Marechal Floriano ficará a glória
do patriotismo esclarecido com que se tem havido trabalhado para a consolidação da República sob um
governo civil (...) a seriedade do seu governo é incontestável e o último dos seus atos, deixando que as
eleiçóes corressem com a máxima liberdade, sem os costumados roubos de votos e trapaças degradantes,
muita honra faz a quem se constitui uma exceção. (BRITO: 1944: 24)

Nesse sentido, é possível vislumbrar que a fidelidade de Saturnino de Brito ao governo de Marechal Floriano Peixoto e a sua campanha por uma transição política respaldada pela Constituição se explica pelo receio de uma vitória da oposição heterogênea na eleição presidencial, 
o que significaria desvios na doutrina positiva e falta de ortodoxia política. O regime se dispersaria pelos rincões de poder oligarca sem a tutela de indivíduos rígidos em seus princípios, sem os homens retificados de espírito progressista e nacionalista que não tivessem ambições personalistas.

Brito desconsidera a possibilidade de uma política feita sob o voto das massas, provavelmente se referindo a anseios de trabalhadores socialistas e anarquistas presentes no Rio de Janeiro. Ademais, desconsidera também a possibilidade da política em meio às articulações partidárias, o que para ele significaria naquele momento a penetração dos interesses de potentados locais no governo federal.

O êxito da eleição presidencial foi acima da expectativa dos governistas e fez à miserável oposição a mais formal condenação (refiro-me à gente do trapo branco e a seus partidários que em terra covardemente se limitam ao apoio platônico e à guerra pela vil mentira) Agora dir-te-ei francamente qual a impressão que me causon o teu procedimento abstendo-te de votar, embora de acordo com o que disse minha carta política e com a indicação do nome do Sr. Prudente de Morais (...)

$1^{\circ}$ o sistema eleitoral se baseia sobre o poder concreto do número; as maiorias decidem a questão (já mostrei que isso de nada vale, mas agora, no argumentar, coloco-me sob o ponto de vista dos que preconizam o sistema).

$2^{\circ}$ os Estados que anteriormente e posteriormente aos dois dias em que tiveram lugar as eleiçoes, se achavam em estado de sitio, constituem minoria e essa é insignificante se atendermos a que em muitos Estados a suspensão de garantias constitucionais se reduzia às capitais; logo, a propaganda a favor de candidatos oposicionistas, poder-se-ia fazer abertamente pelos periódicos do interior que dão curso às infâmias e mentiras dos boateiros e transcrevem os boletins dos revoltosos;

$3^{\circ}$ a Constituição não previu o caso excepcional em que nos achamos e não diz. durante quantos dias antes da eleição é necessário que o país inteiro goze das liberdades constitucionais dos tempos normais; logo é legal, é constitucional, o ato do Governo suspendendo o estado de sítio para que fossem realizadas as eleições e durante o tempo mais que necessário para tal realização. Inconstitucional seria adiar, contrariando letra expressa, as eleiçoes, pois que o dia se acha fixado, não admitindo sobre pretexto algum prorrogação;

$4^{\circ}$ supondo que em questão de tal monta sirva de argumento o afastamento das urnas a que se acham condenados os presos políticos, lembrarei que em maior número são os governistas que não puderam votar por se acharem em seus postos de guerra ou em comissões resultantes da revolta. (ALVARENGA: 1979: 46)

O movimento republicano havia aglutinado intelectuais de diferentes matizes como os antigos militantes do movimento abolicionista, como José do Patrocínio e escritores como Olavo Bilac, além de um gama de outros pensadores. O apoio ao Governo Provisório se ancorava numa áurea de alianças políticas que se perderam com as sedições, além dos militares se arvorando ao poder. Tanto o governo de Deodoro da Fonseca quanto o de Floriano Peixoto são marcados pela ação moralista de autoridades públicas, como o chefe de polícia perseguindo populares, reprimindo jogos de apostas, o entrudo e a tudo o que representaria uma subversão da ordem moral. Assim, a grande popularidade no início da república esteve, ao contrário, com o Imperador e a Princesa Isabel, como se observou na festa no Paço Imperial pela ocasião do aniversário de D. Pedro II, com uma grande quantidade de negros e a presença de um príncipe Obá para saudar o Imperador.

Os apoios políticos de Saturnino de Brito possuíam, nesse sentindo, o mesmo objetivo dos republicanos que queriam enterrar a monarquia. Sob um regime político composto por homens de envergadura científica estaria garantida a atuação institucional de engenheiros sanitaristas em esferas estatais de poder. Porém, o fato de os republicanos não possuírem grande adesão social naquele momento era um problema central ao novo regime que necessitava da organização de um 
novo pacto de poder que substituísse o arranjo político imperial.

Ao longo de toda a primeira década da República se enfrentará essa crise institucional e política representada pelos motins, sedições e manifestações populares tanto na capital federal quanto em antigas províncias que aspiravam por maior autonomia como na Revolução Federalista. Logo, porém, os setores econômicos mais poderosos da nação, que lidavam com a exportação de café e pretendiam a manutenção de um país unido, se impuseram a tarefa de neutralizar o que vinha acontecendo na capital federal e em alguns estados separatistas. Esse grupo retira os militares do poder com a eleição de Prudente de Morais, o que diminui o peso da participação popular na política, além de iniciar um processo de cooptação de oligarquias estaduais.

Contrariando as intenções de Saturnino de Brito de neutralizar o poder dessas oligarquias locais através da centralização estatal, como por exemplo no fortalecimento das Comissões de Saneamento. Campos Sales, o segundo presidente civil da República irá compor um arranjo político nacional através da capilaridade do poder dos cacifes políticos nos municípios. Assim, o domínio local, tão criticado por Saturnino de Brito em seus relatórios, entra no arcabouço institucional do Estado Nacional através de uma estrutura de apoio dos Partidos Republicanos estaduais.

Após 1898, durante as primeiras décadas do século XX, se verá nos relatórios produzidos pelo engenheiro, como no caso do Abastecimento D'água de Ribeirão Preto, inúmeras críticas sobre o arranjo da Política dos Governadores elaborado por aqueles primeiros presidentes paulistas que Brito havia apoiado durante a Assembleia Constituinte. Ao longo de toda a República Velha, Saturnino de Brito irá se referir inúmeras vezes ao poder das oligarquias locais como nefasta ao desenvolvimento de Planos Urbanos que abrangessem a cidade como um todo.

\subsection{Plano Diretor politicamente neutro?}

José de Oliveira Reis, que irá elaborar uma peça urbanística para Ribeirão Preto, também teve que lidar com as nuances do poder político oligárquico, não só na esfera da Câmara Municipal da cidade, mas ao longo de toda a sua trajetória profissional pelas esferas institucionais do urbanismo brasileiro. A sua carreira se insere num outro contexto político e econômico, principalmente durante a Era Vargas, quando o país atravessava um período de desenvolvimento urbano e industrial sob um processo de centralização estatal. ${ }^{9}$ Vemos Oliveira Reis às voltas com as administrações municipais, adotando posturas semelhantes às de Anhaia Mello num movimento pela modernização da administração pública no país, principalmente por influência de teorias norte-americanas, ao defender a desvinculação das questões do urbanismo da política local.

De certo modo, há uma lógica no planejamento municipal condicionado a prescrição constitucional que estabelece a autonomia do município. E, ainda que assim não fosse, bastava à conceituação do município definida pela "Carta dos Municipios" que diz:

\footnotetext{
9 Ver RESENDE, V.; Ribeiro, F. de A. A arquitetura e o urbanismo modernos no Distrito Federal, escolha ou consequência na Era Vargas? Seminário DOCOMONO. (versão online, acessado em 19/12/2014: http://www. docomomo.org.br/seminario $\% 208 \% 20$ pdfs/004.pdf).
} 
"O município é o um grupo natural da sociedade, constituido por um conjunto de famílias e organiz̨ado como unidade política primária"

A ideia do planejamento de área inicia-se por essa "unidade política primaria" e se amplia por toda uma região. (REIS, 1955: 3)

Essa atuação ocorre no âmbito da defesa das Comissões de Plano da Cidade e dos Departamentos de Urbanismo como órgãos por excelência das questões de urbanismo, da mesma forma que propunham alguns autores norte-americanos. Era imprescindível aos órgãos de planejamento urbano, segundo os estadunidenses, uma total autonomia das instituições de poder do executivo e legislativo, constituindo o que Anhaia Mello chamava de o quarto poder da administração municipal. ${ }^{10}$ Nesse sentido, é possível enxergar na elaboração do projeto do Plano Diretor de Ribeirão Preto de 1945 e na palestra proferida por José de Oliveira Reis na Câmara Municipal da cidade, a visão de planejamento desse urbanista fundada no entendimento do que Feldman (2005) define através da leitura dos textos de Anhaia Mello:

"planejamento, como qualquer técnica, é politicamente neutro; há um processo, pois, que deve ser seguido por todos, para acertar". Está visão de planejamento que procura imprimir ao setor de urbanismo, que parte de soluções técnicas e racionais, divorciadas dos conflitos sociais, denota uma visão tecnocrática para resolução dos problemas urbanos. Ou seja, denota a crença de que um corpo de técnicos com validade universal, independentes dos sistemas politico e social local, se aplicadas corretamente, têm o poder de atender ao interesse público, mais que qualquer outro mecanismo. (FELDMAN: 2005: 49)

José de Oliveira Reis, apesar de egresso do curso de engenharia civil da Escola Politécnica do Rio de Janeiro, possuía, sem dúvida, contato com as publicações de Anhaia Mello, enquanto este era titular da cadeira de urbanismo na Politécnica de São Paulo desde a década final da Primeira República nos anos de 1920. Apesar de Anhaia Mello considerar o urbanismo como uma ciência técnica e portanto, politicamente neutra, as suas vinculações políticas tiveram um peso significativo para a penetração de suas ideias e concepções de organização no setor de urbanismo paulistano. Anhaia Mello pertencia ao Partido Democrático (PD), que havia sido fundado no ano de 1926, em São Paulo, pelo patriarca da família Prado e ex-prefeito dessa cidade, Antônio Prado.

O Partido Democrático agregava figuras da elite paulistana que pertenciam a campos profissionais mais ligados a burguesia liberal, possuindo assim o objetivo de quebrar a hegemonia do Partido Republicano Paulista (PRP), ainda bastante dominado por fazendeiros de oligarquias rurais. A partir dos anos de 1930, o PD se associa ao movimento de incorporação do planejamento como função de governo, tendo integrado a Aliança Liberal de apoio à candidatura de Getúlio Vargas contra o candidato do PRP, Júlio Prestes, que sairia vencedor das eleições presidenciais.

Desse modo, o trânsito político institucional de Anhaia Mello se dá durante a Era Vargas, como prefeito em 1931, ainda no Governo Provisório, e como secretário do estado de São Paulo, durante o Estado Novo. As suas ideias e concepções de urbanismo na administração municipal paulistana, consequentemente, são absorvidas em virtude da presença de Abrão Ribeiro, membro

10 Ver o primeiro capítulo do livro de FELDMAN, S. Planejamento e Zoneamento, São Paulo (1947-1972). São Paulo: Edusp/Fapesp, 2005. 
do PD, prefeito em 1945, e do arquiteto Christiano Stockler, também como prefeito em 1947, momento da criação do Departamento de Urbanismo. A proximidade de Jânio Quadros ao municipalismo também facilita, posteriormente, a penetração das propostas de Anhaia Mello em diversos momentos da administração municipal paulistana. ${ }^{11}$

Dessa forma, apesar da bandeira sobre os Planos Diretores politicamente neutros, os contatos políticos de Oliveira Reis, num movimento semelhante ao de Anhaia Mello, serão fundamentais para a sua carreira e a penetração de suas ideias no âmbito da administração pública. A formação de José de Oliveira Reis enquanto urbanista, segundo Rodrigo Faria (2007), também ocorrerá principalmente nesse percurso da institucionalização do urbanismo pelas administrações municipais brasileiras após a Primeira República. A sua trajetória profissional se inicia em 1931, durante a Era Vargas, ao ingressar como engenheiro na administração municipal por concurso público realizado na gestão de Pedro Ernesto. Essa gestão é decisiva para estruturação da Comissão do Plano da Cidade, instalada pelo prefeito Henrique Dodsworth, já durante o Estado Novo, e que será chefiada por José de Oliveira Reis.

Desse modo, durante um período de recrudescimento da autonomia municipal durante o Estado Novo com a nomeação pela esfera federal aos cargos de prefeitos, a relação entre José de Oliveira Reis e Henrique Dodsworth será crucial para a existência da Comissão do Plano da Cidade:

Relação de centralização ampliada no Rio de janeiro, por ser sede das duas instâncias administrativas públicas, a União e o Município, cuja resultante beneficiava a Comissão do Plano da Cidade na elaboração de um plano urbano e de obras para Capital Federal, que estava sob sua responsabilidade. O beneficio estava articulado justamente ao processo político de nomeação do prefeito, no caso Henrique Dodsworth, partidário e amparado do pelo Estado Novo, que legitimava e garantia a autonomia da Comissão do Plano da Cidade, sempre justificada no campo da técnica. Interessadamente definida como neutra, distanciada do campo político-partidário (FARIA: 2007: 161)

Ao longo desses anos, numa articulação entre a Comissão do Plano da Cidade e a Secretaria de Viação e Obras Públicas, representada por Edison Passos, Oliveira Reis consegue importantes encaminhamentos no campo administrativo para as realizações urbanísticas. Em 1941 organizará no Rio de Janeiro o I Congresso Brasileiro de Urbanismo, e depois ainda participa da transformação da Comissão do Plano da Cidade em Departamento de Urbanismo da Capital Federal em 1945, já na prefeitura de Filadelfo de Barros Azevedo. ${ }^{12}$

Neste ano, José de Oliveira Reis é convidado a elaborar o Plano Diretor de Ribeirão Preto, tendo ainda de voltar ao município em 1955, em virtude da criação na Câmara Municipal da cidade de sua Comissão Especial do Plano Diretor, ocasião em que profere a palestra "O urbanismo e sua influência no município". Assim, os posicionamentos políticos de Oliveira Reis são fundamentais para a sua trajetória profissional, o que indica o motivo de algumas de suas opiniões elaboradas

11 Ver Feldman. Op cit. p. 76.

12 Sobre a trajetória profissional de José de Oliveira Reis entre o urbanismo e a politica no Rio de Janeiro, principalmente, quando ocupou a chefia da Comissão do Plano da Cidade e o Departamento de Urbanismo durante a gestão do Interventor Henrique Dodsworth ver o primeiro e o segundo capítulo da tese de FARIA, R. S. de. José de Oliveira Reis, urbanista em construção: uma trajetória profissional no processo de institucionalização do urbanismo no Brasil (1926-1965/1966). Tese (doutorado). Unicamp. IFCH. Campinas. 2007. 
em rememoração a respeito dos anos finais da Primeira República. Nessa ocasião, Reis realça a importância da gestão municipal de Antonio Prado Junior para o urbanismo, principalmente em função de ter contratado o urbanista francês Alfred Agache para a elaboração do Plano de Remodelação, Extensão e Embelezamento do Rio de Janeiro. ${ }^{13}$

Apesar de sua filiação às concepções de Anhaia Mello a respeito do urbanismo como uma ciência técnica e politicamente neutra, o que José de Oliveira Reis na realidade realiza ao rememorar a evolução do urbanismo em cada uma das gestões administrativas do Rio de Janeiro é a construção de uma narrativa que evidencia os prefeitos que, segundo ele, contribuíram para a formação de uma "cultura urbanística". E, particularmente, aqueles que favoreceram a estruturação da Comissão do Plano da Cidade em torno da discussão sobre o Plano de Alfred Agache e posteriormente durante o Estado Novo na gestão do interventor federal. Dessa forma, numa linha evolutiva, Oliveira Reis aponta que a fermentação daquele debate se inicia na gestão de Antonio Prado Junior (1926-1930), e se reacenderá durante a prefeitura de Henrique Dodsworth (1937-1945) quando o urbanista se torna o chefe da Comissão do Plano da Cidade.

Assim, há o comentário de Oliveira Reis sobre o filho do conselheiro Antonio Prado, patriarca da família Prado e fundador do Partido Democrático em 1926:

Antônio Prado Junior, paulista, oriundo de tradicional família (...) foi o Prefeito do Distrito Federal escolbido pelo presidente Wasshington Luis Pereira de Sousa. Homem viajado, de bom gosto, prestigiado pelo Presidente, pode realizar uma Administracão dotada de bom senso e dinamismo. Uma de suas mais notáveis iniciativas foi a de entregar a Alfred Agache, o estudo do primeiro plano de Remodelação, Extensão e Embelezamento da Cidade, obra de um grupo de técnicos estrangeiros especializados. Desse esforço resultou o Plano Agache, cuja proję̧ão e importância até hoje são reconbecidos. O livro, dele resultante, representou o primeiro estudo sério dos problemas urbanísticos da cidade, visando orientar seu crescimento normal, sistematizando sua expansão natural, metodizando sua vida coletiva e organizando-a administrativamente para atender suas necessidades futuras. Efeito importante do Plano Agache foi o de alertar os engenheiros e arquitetos municipais e despertar interesse nos meios profissionais pelas questões de urbanismo, alargando-lhes a visão para além dos limites dos problemas de ordem local e atraindo para os mesmos a atenção dos municipes (REIS: 1965 apud FARIA: 2007: 17)

Nos elogios aos trabalhos realizados à gestão de Antônio Prado Junior transparece, portanto, a sua filiação aos políticos importantes para o processo de institucionalização do urbanismo na esfera das administrações municipais brasileiras. Ele próprio participa profissionalmente da criação das Diretorias de Obras Públicas, das Comissões de Plano da Cidade e do Departamento de Urbanismo do Distrito Federal. Todavia, seus comentários demonstram também as nuances e ambiguidade desse processo de institucionalização realizado em meio à política oligárquica do final da Primeira República. Oliveira Reis apoia um político de uma oligarquia dissidente da Política dos Governadores liderada pelo PRP, percebendo que a institucionalização do urbanismo integraria a plataforma de partidos políticos mais arraigados ao mundo urbano como no caso do Partido Democrático.

13 Estas rememorações são os seguintes trabalhos que estão citados na tese de doutorado de Rodrigo Faria (2007): “As administrações municipais e o desenvolvimento urbano" (1965); e "Os prefeitos do Rio de Janeiro como Capital da República de 1892 a 1960” (1977), ver FARIA, R. S. de. Op. Cit. 
O Plano do urbanista Alfred Agache seria então contratado pelo prefeito nomeado pelo último presidente eleito na esteira de poder da Política dos Governadores. Washington Luís havia nomeado Antônio Prado Junior como prefeito do Distrito Federal numa tentativa de reconciliação com o seu pai, já octogenário, em virtude das desavenças que o levara a fundar o reformista Partido Democrático. Antônio Prado Junior, por sua vez, como prefeito, de forma semelhante ao que seu pai havia feito em São Paulo, dirige sua atenção à modernização física e ao embelezamento urbano do Rio de Janeiro.

Dessa maneira, é curioso notar que o urbanista José de Oliveira Reis assim como Anhaia Mello se aproxima do Partido Democrático ao final da Primeira República, vendo-o como uma plataforma de modernização que escapasse da política oligárquica dos partidos republicanos. $\mathrm{O}$ manifesto do PD, escrito por Antônio Prado, mencionava a falta de partidos significativos e a consequente flutuação dos negócios nacionais. As fraudes eleitorais levaram alguns membros do Partido Democrático a comporem alianças com outras dissidências estaduais, como no caso do Partido Libertador no Rio Grande do Sul, que antecede a Aliança Liberal que leva Getúlio Vargas ao poder em $1930 .{ }^{14}$

Já os elogios a Washington Luís passavam pela posição deste político a favor do municipalismo na Assembleia Constituinte de 1905 e, posteriormente, ao longo de sua trajetória pelos Poderes Executivo e Legislativo. Apesar de ter nascido no estado fluminense, Washington Luís faz sua carreira política no estado de São Paulo, onde atua como deputado estadual, prefeito da capital, governador do estado e, após o seu mandato no senado, como presidente da República do PRP eleito com larga vantagem sobre seus opositores.

A nomeação de Antônio Prado Junior à prefeitura do Distrito Federal também possui relação com a aproximação de ambos durante suas trajetórias políticas pelo estado Paulista. Antônio Prado Junior era conhecido pela ousadia de ter viajado junto a Albert Santos Dumont no balão Lutéce pelos arredores de Paris. Ambas as famílias, Prado e Dumont, possuíam companhias de fazendas de café na região de Ribeirão Preto, cidade bastante próxima a Batatais, onde Washington Luís havia iniciado sua carreira como advogado. Algo curioso na relação entre Washington Luís e Antônio Prado Junior era a coincidência pelo entusiasmo aos veículos automotores e estradas de rodagem. Washington Luís foi ao longo de sua trajetória política um dos principais patrocinadores de congressos e associações pelo desenvolvimento da malha rodoviária paulista, posição que também era defendida Antônio Prado Junior em suas referências ao desenvolvimento dos Estados Unidos, o que por sua vez os aproximavam também de Anhaia Mello.

Antônio Prado Junior protagoniza a primeira travessia automobilística entre a capital paulista e a cidade de Santos com o veículo francês Motobloc. Em 1908, possivelmente, o futuro presidente da República o encontra na Grande Corrida realizada em São Paulo pelos integrantes do Automóvel Club da cidade. Na época, Washington Luís era Secretário de Justiça e Segurança Pública, o que o permitiu reivindicar a realização da corrida junto ao prefeito municipal Barão

14 Ver LEVI, D. A família Prado. 1977 p. 304. 
Raimundo Duprat. Os colegas do secretário realizavam as reuniões do Automóvel Club na casa de outro integrante da família, Martinico Prado, no antigo Largo do Rosário e devem ter sido calorosamente cumprimentados pelo prefeito e secretário no banquete de confraternização da primeira prova automobilística da América do Sul.

Segundo Faria (2007), as rememorações de José de Oliveira Reis a respeito da contração de Agache pelo prefeito Antônio Prado Junior compõem uma construção discursiva em relação à institucionalização do urbanismo na administração pública brasileira. Dessa forma, o urbanista reconstrói os personagens segundo a sua intenção de posicioná-los enquanto figuras políticas importantes para a consolidação daquela disciplina em esferas estatais:

Antônio Prado Junior, sem possuir qualquer título profissional, sem ser engenheiro, foi, entretanto, um dos maiores prefeitos da cidade do Rio de Janeiro, oriundo de tradicional família paulista, filho do velho e conceituado Conselheiro Antônio Prado era apenas dedicado à vida particular e social nos clubes esportivos de São Paulo. Homem viajado, de bom gosto, dinâmico, amigo pessoal do Presidente da República, este o foi buscar, como elemento de confianca, para dirigir os destinos da capital da república durante seu quadriênio. Foi uma feliz escolha, pois sem títulos e sem preconceitos técnicos, fez. uma administração dotada de bom senso e com uma invulgar disposição para o trabalbo. Prado Junior, pela atuação não desmereceu a confiança nele depositada pelo Presidente da República (...). Ao perído mais ou menos tranquilo, equilibrado da administração Alaor Prata, sucedeu a deoutro prefeito de características dinâmicas incansável trabalhador, revolvendo tudo, agitando problemas e deixando marcado, de modo indelével, a sua passagem pela prefeitura do Distrito Federal. (...) O Governo Municipal não deixa de ser um reflexo do governo federal. A austeridade e seriedade do governo Washington Luis, reproduzia-se na administração da prefeitura, através da atuação do prefeito Prado Junior, cuja personalidade marcante e austeridade no trato dos negócios publicados eram bem uma continuação do Presidente da Republica. . (REIS: 1965: 89 apud FARIA: 2007: 21)

Reis também era oriundo da região de Ribeirão Preto. Filho de um menos próspero produtor de café, conhecia os integrantes da tradicional família paulista em virtude da presença das celebres fazendas na região de Ribeirão Preto - São Martinho e Guatapará. Curiosos são os comentários positivos de Saturnino de Brito em relação aos progressos da administração de Antônio Prado no que se refere à continuidade das ações de reformas na prefeitura da cidade de São Paulo. No estudo que o engenheiro realiza sobre o abastecimento d'água da capital paulista, contemporâneo ao período do governo municipal do conselheiro, também aparecerá opiniões favoráveis à família Prado em virtude de sua dissidência a Política dos Governadores:

Na capital do Estado de S. Paulo o prefeito tem sido eleito, mas, por excepsão, o bom senso e o patriotismo tem escolbido, independentemente do Governo, durante quatriennios sucessivos, o sr. dr. Antonio Prado, homem superior, afastado da política. Por feliz acaso se tem tido competência do eleito e a continuidade na administração; o povo evitou o perigo do systema eleitoral, fazendo boa escolha, elle mesmo. (BRITO: 1912: 309)

Tanto Saturnino de Brito quanto José de Oliveira Reis se aproximam de Antônio Prado em função do seu papel como crítico aos partidos republicanos estaduais. Para o conselheiro do Partido Democrático os Partidos Republicanos seriam simples agrupamentos de políticos sem uma plataforma nacional e modernizante. Uma plataforma política que Getúlio Vargas tentará absorver após a morte de Antônio Prado, em 1929, quando aquele procurou fortificar o eixo Rio Grande do Sul - São Paulo através das ideias políticas cafeeiras que vinham sendo ignoradas pelos políticos do PRP. 
Nesse sentido, para ambos os engenheiros - Saturnino de Brito e José de Oliveira Reis - a condição de existência do urbanismo enquanto uma ciência autônoma dependia de sua independência da política praticada, principalmente no âmbito do poder das oligarquias estaduais da Primeira República. Segundo Darrell Levi (1977), durante os anos em que Antônio Prado fora prefeito de São Paulo, entre 1889-1910, se revelou o seu desinteresse pela política republicana, relutando em aceitar o novo jogo clientelístico das indicações do PRP, estando mais inclinado à restauração da estabilidade política monárquica:

O que Antônio Prado parecia querer era uma República que tendesse à suposta estabilidade da Monarquia. Em particular, achava o tempo de mandato do presidente muito curto: um novo presidente gastava o primeiro ano estabelecendo sua política; o segundo servia ao inicio de sua implementação; o terceiro era ocupado pela preparação para próxima eleição; e o quarto ano, presumivelmente, era ocupado com as eleições mesmas (LEVI: 1977: 297)

A prefeitura da cidade de São Paulo era um cargo menor que Antônio Prado ocupava procurando evitar as alianças políticas para candidaturas maiores. A sua gestão no município, todavia, significou a ambiguidade de uma figura do Antigo Regime liderar um governo progressista numa atmosfera de desenvolvimento material. As referências de Brito a Antônio Prado, e mesmo as de José de Oliveira Reis em relação a essa família, estão associadas à notoriedade que ele adquiriu ao levar para administração pública as técnicas comerciais que haviam conquistado nos seus prósperos negócios particulares.

Seu programa diário como prefeito consistia em rápidas visitas às obras municipais, ao curtume da Água Branca, à vidraria Santa Marina, ao Banco do Comércio e Indústria, e à Paulista. Um de seus primeiros projetos foi supervisionar a pavimentação das principais ruas da cidade. A 7 de maio de 1900, inaugurou pessoalmente a primeira linha de tróleis elétricos da cidade, dirigindo o primeiro carro do largo São Bento, no centro da cidade, até o fim da Alameda Barão de Limeira, onde ficava sua mansão, a chácara do Carvalho. Antonio também promoven o necessitado embelezamento dos parques e praças da cidade, e a praça da República permanece ainda hoje como um dos marcos de sua administração. (LEVI: 1977: 298)

As aproximações de Brito e Oliveira Reis aos prefeitos municipais da família Prado estavam vinculadas a distinções que os integrantes da família haviam recebido como uma elite modernizada de gestores eficientes e enérgicos. Eles acompanhavam, dessa forma, a opinião do próprio engenheiro da cidade de São Paulo, Victor da Silva Freire, que assim a expressa no caso da vigorosa repressão à greve na Cia. Paulista de Vias Férreas e Fluviais, em 1906, quando Antônio Prado foi elogiado por figuras do establishment paulistano pela firmeza contra a "anarquia" trabalhista. Assim, Brito e Oliveira Reis associam a um modelo administrativo desvinculado tanto da politicagem das oligarquias quanto das manifestações das massas, procurando estabelecer um estatuto científico e institucional "politicamente neutro" ao planejamento urbano.

Portanto, quais os ideais dos autores urbanistas ao realizarem os seus trabalhos no âmbito das cidades pelas quais passaram e, especificamente, quanto aos planos que elaboraram para Ribeirão Preto. ${ }^{15}$ ? Mas, quais seriam as clivagens ou diálogos, neste caso particular, entre os planos

15 Considerando que não existiu um plano especificamente elaborado por Saturnino de Brito para Ribeirão Preto, com exceção de um parecer emitido em 1912 sobre a situação da rede de água e esgoto da cidade. Brito integrou como engenheiro chefe o $2^{\circ}$ Distrito da Comissão de Saneamento do Estado de São Paulo, onde elaborou um plano para 
ou concepções urbanísticas e a história da cidade de Ribeirão Preto no período que abrange as duas elaborações?

cidade de Campinas, modelo no âmbito da Comissão e das cidades do interior paulista. A sua trajetória pelo interior paulista é fundamental para a elaboração de sua concepção sobre a necessidade de Planos de Conjuntos, inclusive, com o sistema de abastecimento de água e coleta de esgoto como um dos elementos centrais do que Brito considerava como o Conjunto das obras para a cidade. 
Capítulo 2 
A ARTE DE SE CONSTRUIR CIDADES EM MEIO À POLÍTICA LOCAL 


\subsection{A ocupaçáo da bacia hidrográfica do Ribeirão Preto.}

Com o objetivo de levantar alguns aspectos formação da cidade de Ribeirão Preto ao longo da segunda metade do século XIX, sobretudo, para colocá-los diante das polêmicas que envolveram Saturnino de Brito, é importante remontar ainda que de maneira breve o processo de ocupação do território do Nordeste Paulista onde a cidade está situada. Este é o momento da constituição das principais famílias que irão disputar a política republicana local, principalmente em torno da construção material da cidade.

Ao passarmos pela polêmica sobre a crise de falta d'água, quando o serviço já era administrado pela Empresa de Água e Esgotos, pertencente à família Prado, contrapomos a opinião de alguns engenheiros sanitaristas, como Saturnino de Brito, frente à gestão das águas que era praticada no município. O destaque à noção de Plano de Conjunto defendida pelo engenheiro ${ }^{16}$ se tornou importante para relativizar a formação do monopólio dos serviços urbanos realizado pela Empresa de Força e Luz de Ribeirão Preto. O crescimento urbano de Ribeirão Preto pode ser acompanhado, dessa forma, pela apropriação de seus recursos hídricos, contrapondo as particularidades históricas do tratamento e controle de suas águas frente ao nascimento e a consolidação da urbanística moderna.

A cidade de Ribeirão Preto está assentada em meio à pequena bacia hidrográfica do ribeirão Preto $^{17}$, que nasce numa área mais alta numa região que pertencia à antiga fazenda de café do agricultor positivista Luiz Pereira Barreto, cruzando toda a extensão da cidade até desaguar no rio Pardo, ao norte do município. A criação de freguesias e vilas nessa região bastante desabitada durante os séculos XVI e XVII ocorre, posteriormente, no mesmo rumo da trilha do Anhanguera, o bandeirante que havia aberto esse caminho às Minas Gerais:

Desde o ano de 1655, o território cortado pela trilha ligando a cidade de São Paulo às terras dos indios Goiazes pertenceu ao então município de Jundiaí. Em 1769, sua porção Norte passou para a jurisdição da recém-criada vila de Moji mirim. (...) Essa Antiga circunscrição administrativa,

16 BRITO, S. Le tracé sanitaire de la ville .Obras Completas. Rio de Janeiro: Imprensa Nacional, 1944.

17 O córrego Ribeirão Preto nasce no centro da cidade de Cravinhos, cerca de 800 metros acima do nível do mar, desce cortando o município de Ribeirão Preto, passando pela região central da cidade aproximadamente a 540 metros de altitude, e deságua no rio Pardo já na divisa com o município de Jardinópolis a 500 metros de altitude. A bacia do Ribeirão Preto é a principal bacia da cidade, porém outras duas cortam o município de Ribeirão Preto, a do córrego das Palmeiras e a do córrego do Esgoto. 
por sua vez, sofreu uma primeira fragmentação ao ser criada a vila de Franca, em 1823. O segundo desmembramento ocorreu apenas em 1841, quando da instalação da vila de Casa Branca. Desta, nasceu São Simão, datada historicamente de 1865. Historicamente, Ribeirão Preto pode ser considerado um município novo dentro da área descrita, pois foi desmembrado de São Simão em 1871. Esses municípios e os demais a que deram origem foram sendo criados à medida em que a ocupação se adensava (BACELLAR \& BROSCHI: 1999: 18).

A formação do arraial de onde se elevaria a freguesia de São Sebastião do Ribeirão Preto se inicia por volta de 1850, nesse território drenado pela bacia hidrográfica do ribeirão Preto, numa região que a princípio abrangia ainda outras pequenas bacias posteriormente desmembradas como territórios de novas cidades. A doação de terrenos ao Patrimônio Religioso da Igreja de modo a garantir a legitimidade do assentamento e da posse da terra dos fazendeiros do entorno é, inicialmente, o que desperta o desenvolvimento da cidade ao redor do largo da Matriz, no cume de uma região próxima à confluência do ribeirão Preto com o córrego do Retiro Saudoso ${ }^{18}$.

Ao mesmo tempo, a terra do santo que é a matriz da organização urbana transforma-se em elemento de comprovação utilizado amiúde nos litígios sobre posses rurais, principalmente nas fazendas da Barra do Retiro e do Retiro - ampla extensão territorial compartilhada porposseiros que engrossaram as levas mineiras sobre as bacias do Pardo e do Mogi-Guaçu, no inicio do século XIX (GARCIA, 2013:33)

As construções dos edifícios, inicialmente implantados na retícula organizada pela Fábrica da Matriz, irão ao longo do século XX se expandir em direção aos principais córregos que compõem a bacia hidrográfica da cidade - córrego Serraria, córrego Loureano, córrego do Tanquinho e o córrego das Palmeiras. Ao final do século XX, boa parte da extensão desses rios dentro do espaço urbano terá uma densa ocupação de suas várzeas e margens (MAPA 1).

Com a abolição do sistema de mercês realizado pela Coroa Imperial durante o processo de independência, em 1822, se intensifica a apropriação de terras através do apossamento de regiões muito extensas sob o domínio de poucas sesmarias. A ocupação desse território de Ribeirão Preto remonta, notadamente, ao processo de fixação de povoadores mineiros no Nordeste Paulista que regressavam da antiga frente de expansão valendo-se do apossamento de terras que haviam sido abertas pelas bandeiras no caminho de tropas de muares em direção às Minas Gerais e ao Goiás. ${ }^{19}$

A baixa densidade demográfica e a ausência quase completa de titulação permitiram aos entrantes mineiros a constituição de grandes propriedades rurais voltadas ao mercado interno de abastecimento. ${ }^{20}$ As demarcações das fazendas acompanhavam esse fluxo migratório vindo do interior do país, e chegam a ocupar, durante a primeira metade do século XIX, grande parte do território à margem direta do rio Pardo, se estendendo à montante do rio Preto no sentido do maciço de sua nascente.

18 Um trabalho que aborda a constituição e o processo de urbanização do Patrimônio Religioso de Ribeirão Preto demonstrando através de litígios judiciais a origem de um mercado de terras urbanas nesta cidade é GARCIA, V. E. Do Santo? Ou de quem ... Ribeirão Preto: gênese da cidade mercadoria. Tese de Doutorado. São Carlos:IAU/USP, 2013. 19 BACELLAR, C. de A. Uma rede fundiária em transição. in: BACELAR, C. de A. P. \& BRIOSCHI, L. R. (orgs) Na estrada do anhanguera: uma visão regional da história paulista. São Paulo: Humanitas, FFLCH/USP, 1999.

20 Uma ocupação do solo em grandes extensões de áreas ociosas que podiam ser cedidas a outros sem prejuízo econômico ao doador, sendo a situação fundiária geradora da figura dos homens livres, os agregados e compadres, ver FRANCO, M. S. de C. Homens livres na ordem escravocrata. 4.ed. Unesp, São Paulo, 1997. 
ESS'IIAD OD IDE S.PAUILO

degrafico e geologico do estado de são paulo

ENG: DR. ANNIBAL ALVES BASTOS

\section{$=$ BRASIL}

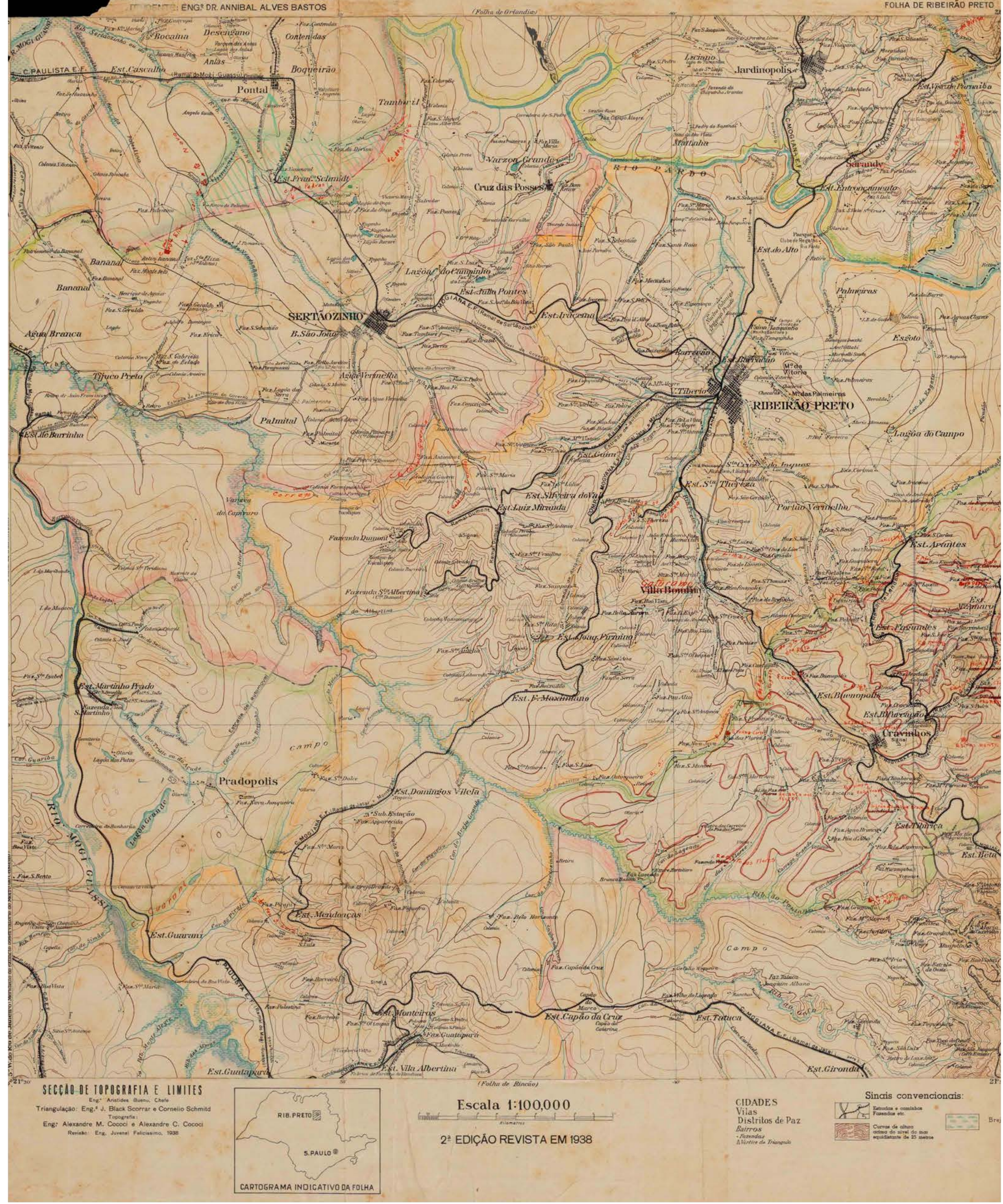

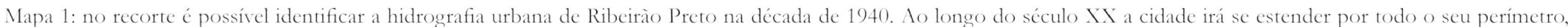


Aos posseiros era fundamental o aproveitamento das pequenas bacias hidrográficas como norteadoras dos limites de suas propriedades, definidas, principalmente, pelas linhas dos topos de morros e dos leitos de córregos. Além disso, o acesso aos cursos d'água era imprescindível para o funcionamento dessas fazendas de criação, podendo a falta d'água forçar a venda das terras e até mesmo a dissolução da fazenda.

Lucila Reis Brioschi (1999) aponta que, apesar dos campos que margeiam os vales do MogiGuaçu e o ribeirão da Onça serem conhecidos desde 1760, a ocupação da margem esquerda do rio Pardo ainda irá tardar em virtude da presença da densa cobertura vegetal - as grandes manchas de terra roxa e a boa oferta hídrica permitiram o desenvolvimento de formações florestais com árvores de grande porte e rica biodiversidade. Tais florestas eram um empecilho para criadores de gado e lavradores de roças de subsistência que ainda não possuíam recursos técnicos para a derrubada e conservação dos solos férteis.

Encontrando essa ocupação rala ao sul do rio Pardo, alguns descendentes dos paulistas povoadores do Caminho de Goiás e novos entrantes mineiros cruzaram esse rio e apossaram terras na sua margem esquerda, por volta de 1811. Entre eles encontrava-se Dias Campos português que chegou ao Sertão do rio Pardo depois de sua passagem pelas Minas Gerais, onde constituiu familia. Possuia terras na fazenda Boa Vista (atual Nuporanga) e fazenda Ilha (atual Jardinópolis) e foi o primeiro posseiro das terras que hoje formam o município de Ribeirão Preto. Por não ter registrado a posse, perdeu-a para os irmãos Mateus e Manoel José dos Reis. Mateus José dos Reis, descendente de antigos povoadores do Caminho do Goiás, em 1829 declarou possuir 120 cabeças de gado na margem do rio Pardo. Ele e seus filhos têm os nomes ligados à fundação da vila de Ribeirão Preto e as disputas que ocorreram por ocasião da doação do patrimônio para a devoção da capela de São Sebastião, em meados do século XIX (BRIOSCHI: 1999: 65).

Posteriormente, o ribeirão Preto aparece como a linha vertente da demarcação efetuada pelos herdeiros da fazenda Laureano na comarca de São Simão. Tudo quanto vertia no sentido do ribeirão pertenceria à fazenda, refletindo o esforço para inventariar pelos cartórios das vilas da região a demarcação da propriedade ${ }^{21}$. Não é mera coincidência que as demarcações dessas glebas dessem importâncias aos córregos, no fundo dos vales, e aos campos e cerrados, rumo à vertente. A necessidade de pastos naturais ditava o rumo da ocupação, e as gerações de herdeiros se arranchavam onde existisse a presença de água.

Algumas famílias foram mais bem sucedidas em evitar a desagregação territorial através dos casamentos consanguíneos, como no caso especial da família Junqueira, que após a conquista de enormes extensões de terras logrou por alianças matrimonias uma fragmentação dessas posses no interior de um círculo familiar fechado.

Talvez. o maior grupo familiar de origem mineira estabelecido na região tenha sido o Junqueira. Durante a segunda década do século XIX, seis casais de netos do patriarca constituiram a primeira geração da família no Nordeste de São Paulo (BRIOSCHI: 1999: 67)

A valorização do café no mercado internacional, porém, promove a especulação fundiária dessas terras apossadas, e essa dinâmica de ocupação muda, a partir da década 1870, com a

21 A corrida pelos registros de propriedades, após a Lei de Terras, integra o projeto de substituição da escravatura enquanto garantia das operações de créditos aos fazendeiros. Um aprofundamento da valorização da terra como mercadoria, além das mudanças da estrutura fundiária no Nordeste Paulista com a chegada do ciclo cafeeiro é visto em BACELLAR, C. de A. op. cit. pp. 93-105. 
subida de cafeicultores do vale do Paraíba, onde os solos se esgotavam. O Nordeste Paulista, numa conjuntura favorável a expansão de cafezais, será reocupado por outros tipos de fazendas associadas a um patamar técnico mais elevado no contexto internacional da Segunda Revolução Industrial. Dois empreendedores, o agrônomo Luís Pereira Barreto e Martinho Prado Junior, se tornam emblemáticos dessa dinâmica de ocupação em virtude das expedições pelo Interior Paulista que realizavam com a publicação dos resultados positivos das análises de terra coletada.

A presença dos mineiros e a sua preponderância na população do Nordeste Paulista durou enquanto o gado e a agricultura do excedente dominaram a economia regional. Com a introducão e expansão da cafeicultura, os paulistas novamente voltam ocupar a região, desta vez acompanhados por fluminenses originários do vale do Paraíba e pelos imigrantes europeus, dentre os quais destacaram-se os italianos (BRIOSCHI: 1999: 76)

O desenvolvimento ferroviário, partindo de Campinas rumo ao oeste da província, encurta o trajeto até o porto de Santos, até então feito em tropas de mula. Essa situação permite a ampliação do espaço agrário àquela lavoura de exportação sobre o maciço do ribeirão Preto, principal eixo de ocorrência de terras roxas. O relevo suave e as duas estações bem definidas de chuvas e secas, além da grande reserva de terras férteis, até então predominantemente cobertas pelas matas de maior porte e sob o domínio de títulos precários, atrai o capital cafeeiro num processo de concentração fundiária e formação de companhias agrícolas.

A aquisição de pequenas áreas de terra por compra possibilitou o ressurgimento das grandes propriedades, especialmente por parte daqueles que detinham capitais próprios on acesso aos de terceiros. Não raro, os recursos para compra originaram-se de estrangeiros, como no caso de Francisco Scbmidt, financiada pela casa importadora alemã Theodor Wille. O capital estrangeiro também adquiriu propriedade em Ribeirão Preto e região, a exemplo da Companbia Agrícola Fažnda Dumont e a São Paulo Coffe States pelos ingleses (MARCONDES; OLIVEIRA: 2013: 270).

No espigão que divide as bacias do rio Pardo e Mogi-Guaçu, onde nasce o ribeirão Preto, as duas correntes migratórias irão se encontrar provocando o choque entre povoadores mais antigos (caso da família Junqueira) e os mais novos (como a família Silva Prado). Os celebres relatos de Martinho Prado $\mathrm{Jr}^{22}$, nesse sentido, possuíam o objetivo de pressionar os antigos povoadores à venda de suas terras a fim de se refugiarem no sertão, num processo em que irá constituir a sua famosa fazenda Guatapará em 1877.

Todavia, apesar da entrada desses novos fazendeiros cafeicultores, os mineiros mantiveram uma preponderância numérica e, muitas vezes, a hegemonia econômica e política na sociedade local até o final do século XIX, ou ainda durante as primeiras décadas republicanas, como no caso de Joaquim Diniz Junqueira no Diretório Municipal do PRP em Ribeirão Preto. No processo de tomada desse espaço, os cafeicultores paulistas e fluminenses irão sempre apresentar uma visão sobre o arcaísmo das condições materiais e dos costumes desses povoadores mais antigos. Martinho Prado Jr, representante da modernização da sociedade paulista, comentava sempre o atraso em que

22 Os capítulos publicados no jornal A província de São Paulo, contando as proezas de sua viagem por uma paisagem vista diante da vertente do ribeirão Preto, em São Simão, serviram de chamariz para outros investidores na cafeicultura. Os antigos lavradores que não se mantiveram na terra acabaram cumprindo a tarefa da abertura de fazendas de café posteriormente absorvidas pelos agricultores com mais capital. Esses relatos são abordados em FARIA. R. dos S.. Ribeirão Preto, uma cidade em construção, 2010; e em BACELLAR, C. de A. op. cit. 


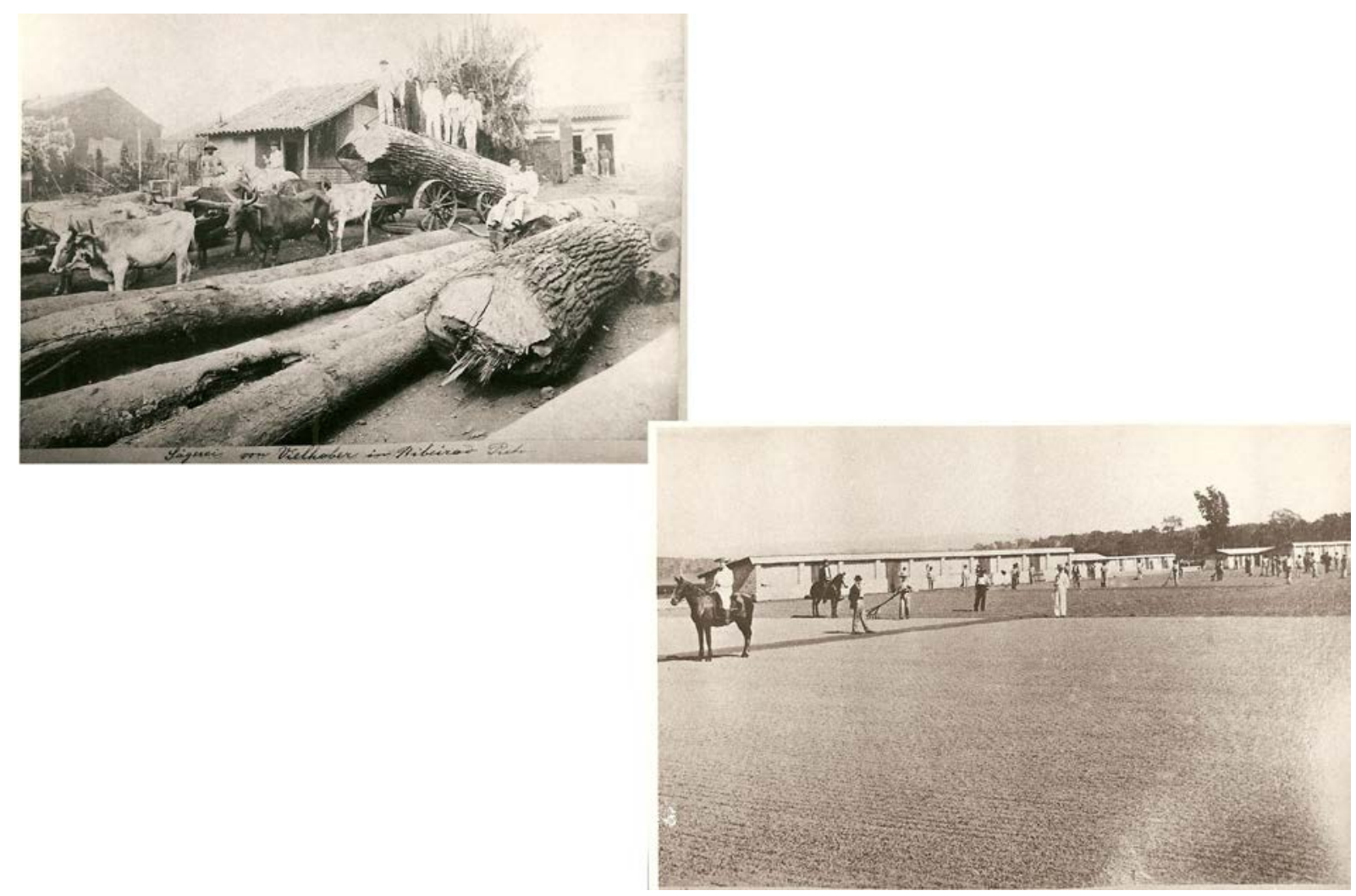

Figuras 4 e 5: A abertura das terras roxas cobertas por grandes matas e a formação de fazendas de café (ao lado). A imagem abaixo mostra os terreiros da celebre Fazenda Guatapará com os trabalhos de secagem sendo realizados sob a vigília de capatazes. A máquina fotográfica já realizava nesse momento a captação das transformações da região com o intuito de publica-las em jornais da capital. Fonte: APHRP.

viviam esses mineiros moradores das terras paulistas:

Seus recursos estão como que paralisados e muitos anos serão ainda precisos para que suas colheitas possam atingir um elevado algarismo. Tanto mais quanto os seus habitantes acham-se possuidos de extremado amos pelas terras incultas, possuem milhares de alqueires, não querem vendê-los, antes desejariam compras mais (PRADO JR apud BRIOSCHI: 1999: 88).

Sob o olhar dos cafeicultores, associados a uma nova etapa do processo de acumulação capitalista, os mineiros representavam o entrave à expansão de novas formas de produção de riquezas. Os novos fazendeiros de café se vinculavam a uma economia agrícola cada vez mais atrelada ao mundo urbano e industrial sem, entretanto, perderem os laços que emanavam da propriedade da terra agrícola e do mundo rural. Como aponta Garcia (2013), a expansão dessa frente pioneira pela região da Mogiana é possibilitada por uma organização jurídico-cartorial apta a assegurar os títulos de propriedades de grandes fazendas antes ocupadas por posseiros. Esse "negócio" de formação de fazendas novas deriva dos desdobramentos da legislação fundiária inaugurada pela lei de terras regulamentada em 1854 e organizada por decretos governamentais emitidos ao longo do século XIX.

A marcha para o oeste, segundo uma perspectiva seguida por Garcia (2013), além de ser motivada pelos lucros da exportação cafeeira durante a substituição do trabalho escravo, é realizada num processo de reapropriação territorial e valorização fundiária rural e urbana. As mudanças jurídicas de domínio geraram um lastro documental e hipotecário dando segurança a um mercado 
de crédito que não mais necessitava se assentar no escravo como capital de custeio. Marcondes e Oliveira (2013) demonstram esse movimento através de uma análise da substituição dos ativos deixados de herança nos inventários post-mortem, em que os escravos e as manufaturas importadas, como bens valiosos, dão lugar ao longo do tempo às propriedades de terras.

O mapa 2 apresenta o resultado dessa ocupação do Nordeste Paulista pelas fazendas de café durante a Primeira República. Uma região que ficou conhecida, após a chegada da linha ferroviária, como a zona da Alta Mogiana, sendo possível enxergar os ramais em direção às fazendas realizando o escoamento do café. A Estrada de Ferro Mogiana, fundada em 1872, partia de Campinas visando atender a toda essa região. Em 1875 ela já havia alcançado Mojimirim e Amparo, sendo inaugurada, em 1878, a linha até Casa Branca conforme o contrato com o governo da Província de São Paulo. Em 1880, a companhia garante a concessão para estender os trilhos até Ribeirão Preto, e o ramal entre São Simão e Ribeirão Preto é construído buscando se aproximar da margem direita do rio Mogi-Guaçu, onde se encontravam os maiores produtores de café, com destaque para os Silva Prado, Francisco Maximiano Junqueira, Companhia Dumont e Silveira do Val. Estes construíram, posteriormente, as estradas "cata-café", com 12 ramais recolhendo o produto até alguma estação da linha principal. Esse processo é descrito por Nestor Goulart Reis Filho (2000: 97) da seguinte forma:

A vantagem do sistema ferroviário e de navegação, convergindo para os grandes portos, terminou por reforçar extraordinariamente a polarização em torno dessas cidades, cuja população se expandiu com intensidade, promovendo novamente a estagnação das vilas litorâneas, junto aos pequenos portos. No caso do estado de São Paulo, como no de Minas Gerais, os entroncamentos ferroviários foram se estabelecer serra acima, promovendo a expansão da capital da provincia e de Campinas, em função do monopólio estabelecido pela São Paulo Railway.

Durante a Primeira República, essa frente de expansão altera profundamente a fisionomia do campo, quase apagando os traços da economia anterior. Apesar das oscilações do preço do café em virtude de superprodução, a lavoura cafeeira sofrerá interrupção apenas ao final da década de 1920, quando a crise mundial derruba o café brasileiro no mercado internacional. Todavia, os novos desbravadores não se restringiram apenas à agricultura, explorando também os novos serviços urbanos, como no caso da criação da Empresa de Águas e Esgotos de Ribeirão Preto, com a derivação dos negócios para empresas de serviços urbanos num período subsequente a consolidação das fazendas de café.

Se, por um lado, os fenômenos da industrialização e da urbanização nos centro hegemônicos europeus definiam os emblemas da modernidade - razão, progresso, velocidade - por outro, grandes massas de pessoas que se deslocavam às cidades-capitais do século XIX (Paris e Londres) enfrentavam as novas paisagens e as sensações de choque e aturdimento - multidão, solidão, pobreza, ilusão - que produziram um movimento dinâmico de homens pela Europa afora em busca de melhores condiçôes de vida.

De certa forma, o surgimento de cidades pelo interior paulista esteve marcado pela fúria Barbara desses homens e mulheres que vieram para regiões de plantio de café em busca de riquezas e sucesso pessoal (PAZLANI: 2004: 6)

No caso da Família Prado, é curioso notar que não os encontraremos posteriormente exercendo papéis de protagonismo político na Câmara Municipal. O poder da família na cidade é 
exercido praticamente apenas pela atuação de Flávio de Mendonça Uchoa à frente de seus negócios como um dos principais empresários locais. Essa marginalidade política dos Prado nos meandros do Diretório Municipal do PRP, ou na Câmara Municipal de Ribeirão Preto, é algo que remete ao que é apontado por Darrel Levi (1977) a respeito da sombra política que cobriu a família ao final da monarquia. Desse modo, veremos o desdobramento de um desses episódios associado à atuação da Empresa de Força e Luz de Ribeirão Preto. 


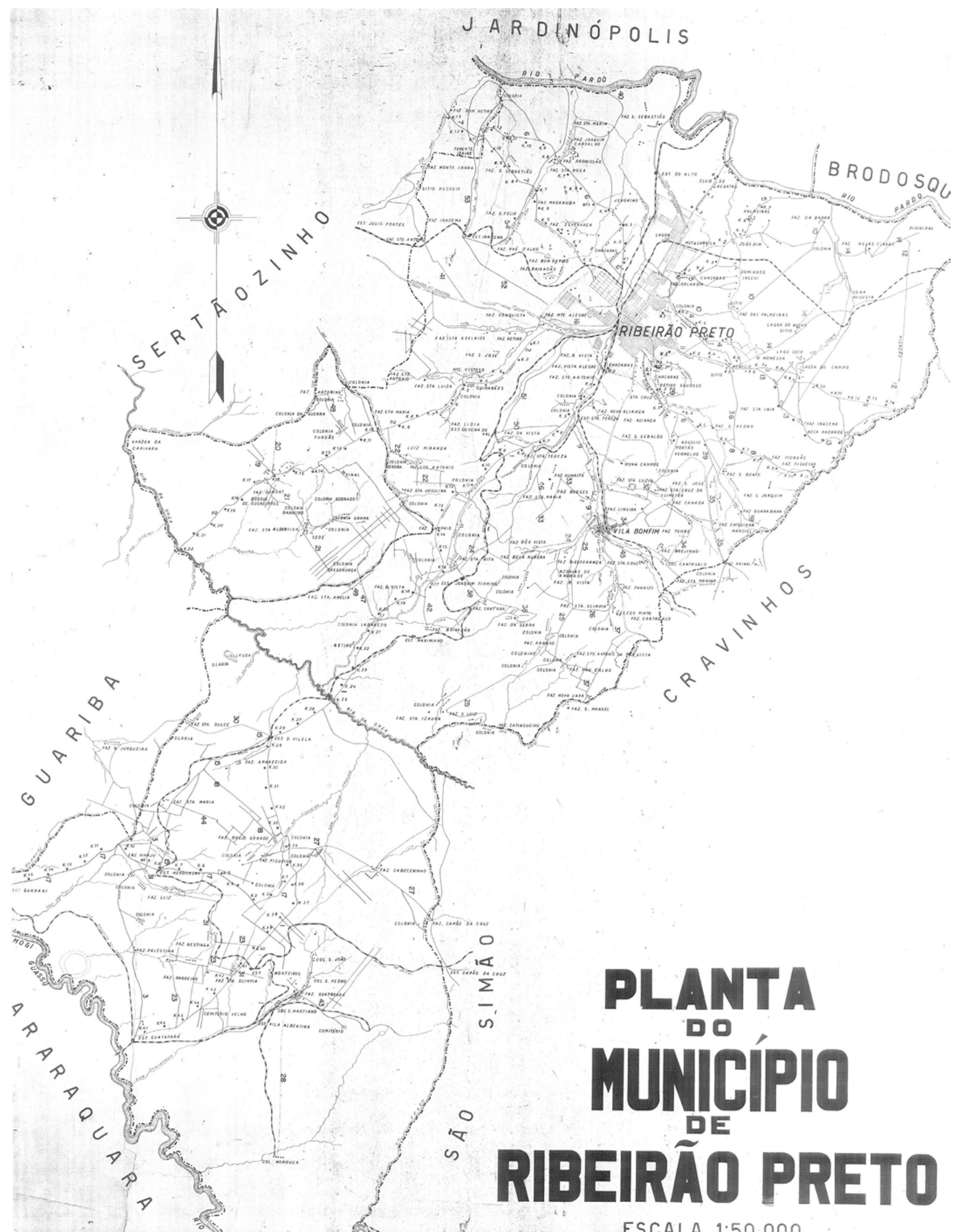

Mapa 2: Nessa representação mapográficâ, possivelmente, do final do final do ciclo cafeeiro, vemos como as fazendas do perímetro urbano foram já bastante repartidas em virtude da atuação dos especuladores de terras que irão futuramente explorar um negócio que se constitui com a repartição das glebas em loteamentos imobiliários. A zona norte do município já se encontrava bem mais estendida do que os outros lados da cidade. Fonte: APHRP. 


\subsection{A cidade entre rios.}

O encontro daquelas duas levas migratórias, marcada, inicialmente, por disputas em torno da terra, também se dará no âmbito dos terrenos e negócios estabelecidos no espaço urbano. Algo que pode ser observado nas disputas entre as Casas Comissárias - Penteado \& Dumont; Junqueira Cia. Exportadora e; Whitaker, Bonfim \& Cia - sobre o domínio do comércio de exportação do café. Mas se evidencia, sobretudo, nos conflitos pelo comando da política oligárquica de Ribeirão Preto, o que deu origem à formação de grupos políticos rivais na disputa pelo controle da máquina administrativa do município.

Garcia (2013) aponta como se aprofundam no espaço urbano as disputas e a corrida pela regulamentação do domínio jurídico para garantir crédito imobiliário, algo que acontece particularmente com os terrenos situados dentro cidade, tendo em vista que seria custoso aos credores dos fazendeiros insolventes assumirem as terras das propriedades rurais, já que o crédito se vinculava ao café enquanto uma mercadoria que garantia o rendimento. Assim, o crescimento urbano, tanto de infraestrutura e edificações quanto demográfico, com a chegada de uma massa de trabalhadores imigrantes, consolida o dispositivo de crédito na cidade através de um lastro hipotecário vinculado às propriedades na área urbana.

Isto ocorre num contexto de transformações históricas ligadas ao aumento da produção cafeeira na pauta de exportações brasileiras, o que culmina no domínio político e econômico do estado de São Paulo sobre o resto do país. A expansão das plantações de café sobre o território paulista promove também o nascimento de diversas cidades, que por estarem conectadas ao mercado europeu pelos trilhos das ferrovias incorporam também novos padrões de sociabilidade e de urbanização.

Paziani (2005) diria:

$\mathrm{Na}$ torrente de mudanças técnico-científicas globais e de reordenamento politico e institucional no país, as pequenas e achatadas vilas de Barretos, Franca, Araraquara, Mococa, entre outras, que, durante o Império, passaram quase incólumes pelo governo monárquico, viram-se integradas a uma sôfrega modernidade no decorrer da Primeira República, atreladas ao universo rural e agricola, representado pelos lucros e pelos espólios da expansão cafeeira (PAZLANI: 2005: 179).

A cidade de Ribeirão Preto se insere durante a Primeira República num quadro de relações mais amplo em virtude do processo de alargamento do sistema capitalista com o advento da Segunda Revolução Industrial. Esse fenômeno da globalização da economia capitalista, que ao longo do século XIX se consolida e se estende para diversas regiões do planeta, modifica de maneira profunda a sociabilidade desses lugares. O capitalismo dessa fase se torna internacional não apenas de forma econômica, mas também de forma cultural, alterando modos de vida. Nessa etapa do capitalismo se desenvolve, por exemplo, a eletricidade e os derivados do petróleo, possibilitando novos campos de exploração industrial, como os altos fornos, a metalurgia e as indústrias químicas, o que gera uma nova gama de produtos que mudaram bastante o cotidiano das pessoas.

O fluxo intenso de mudanças, atingindo todos os niveis da experiência social, que se concentrou de 
fins do século XIX até cerca de meados do XX. Estimuladas, sobretudo, por um novo dinamismo no contexto da economia internacional, essas mudanças irão afetar desde a ordem e as hierarquias sociais até as noções de tempo e espaço das pessoas, seus modos de perceber os objetos ao seu redor, de reagir aos estímulos luminosos, a maneira de organizar suas afeicões e de sentir a proximidade ou o alheamento de outros seres humano. (SEVCENKO: 1998: 7)

Nesse desenrolar surgiram, segundo Sevcenko (1998), os veículos automotores, os transatlânticos, os aviões, o telégrafo, o telefone, a iluminação elétrica, a fotografia, o cinema, a radiodifusão, os arranha-céus, o sistema metroviário e outra série de novos objetos. Tais transformações ocorreram de forma central entre as cidades da Europa e dos Estados Unidos, porém a marca da Revolução Científico-Tecnológica foi a expansão de uma unidade global do mercado capitalista. Assim, se a primeira industrialização modifica lugares com suas fábricas e máquinas, a segunda gera gigantescos complexos industriais espalhando ainda mais suas mercadorias pelo mundo.
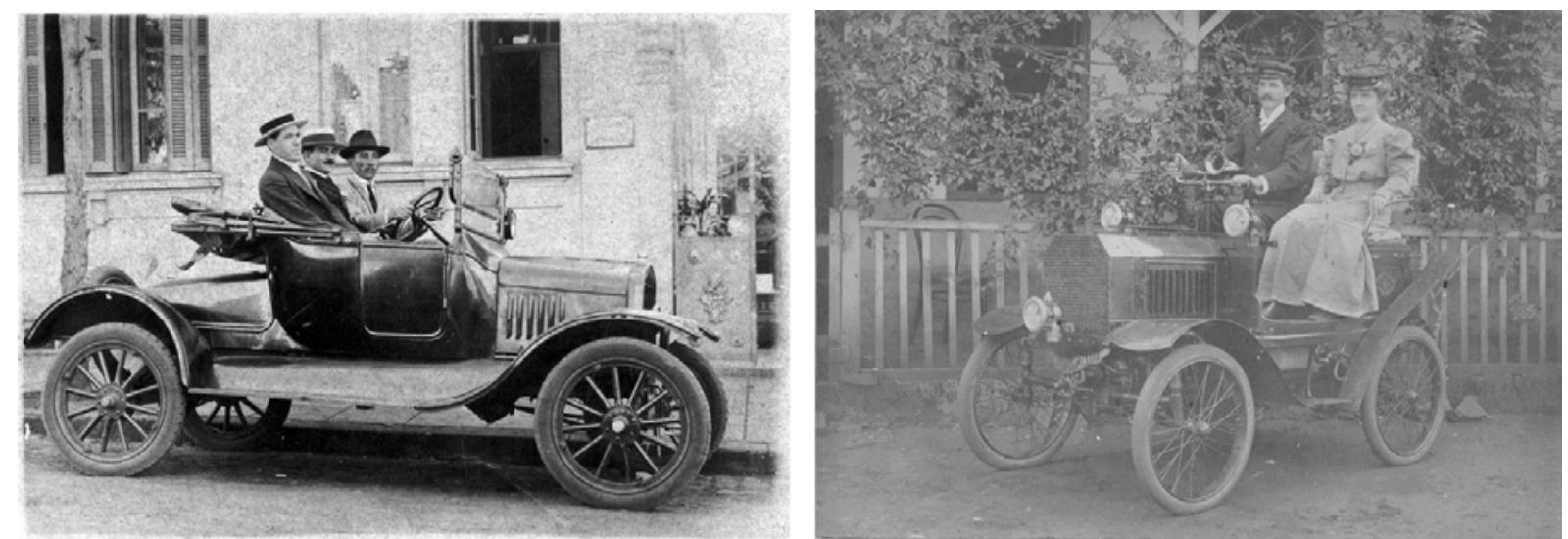

Figura 6 e 7: O automóvel movido à combustão interna, um dos novos inventos da $2^{\mathrm{a}}$ Revolução Industrial chega à Ribeirão Preto. Acima, possivelmente um Ford Model T, que nessa época ainda eram usados mais como símbolos de requinte e notabilidade do que propriamente como meios de transporte individual massificado. Fonte: APHRP.

Durante a Primeira República, portanto, se tem um aumento da construção de edifícios no interior do Patrimônio da Fábrica de Ribeirão Preto, algo que é acompanhado pelo seu crescimento populacional $^{23}$. A população do município salta de 5 mil habitantes em 1873 , para 70 mil em 1920. Contudo, em 1912 o território do município ainda era ocupado por 319 propriedades rurais, sendo os dois destinos dos imigrantes estrangeiros: as colônias das fazendas de café e os bairros suburbanos que se desenvolviam na zona norte da cidade.

Segundo Karla Sanches (2003), o crescimento demográfico do inicio do século XX em Ribeirão Preto chega a ultrapassar em alguns anos a taxa de 300\%, o que acelera o desenvolvimento urbano e ao mesmo tempo o controle pela Intendência Municipal das regras de edificações. Como a maioria dos investimentos urbanos são realizados na região central da cidade, a sua valorização

23 O vilarejo precário até 1889, ainda sem um espaço próprio para a Câmara Municipal, se transforma com os investimentos em obras de infraestrutura e, ao final do século XIX, o aglomerado de ruas mal calçadas recebe os primeiros edifícios como a Cadeia Pública, o Mercado Municipal e o Matadouro. Importante para o crescimento populacional é também a criação do Núcleo Colonial Senador Antonio Prado na zona norte da cidade, um empreendimento realizado pela Sociedade Promotora da Imigração junto ao Ministério da Agricultura por influencia da família Silva Prado. 


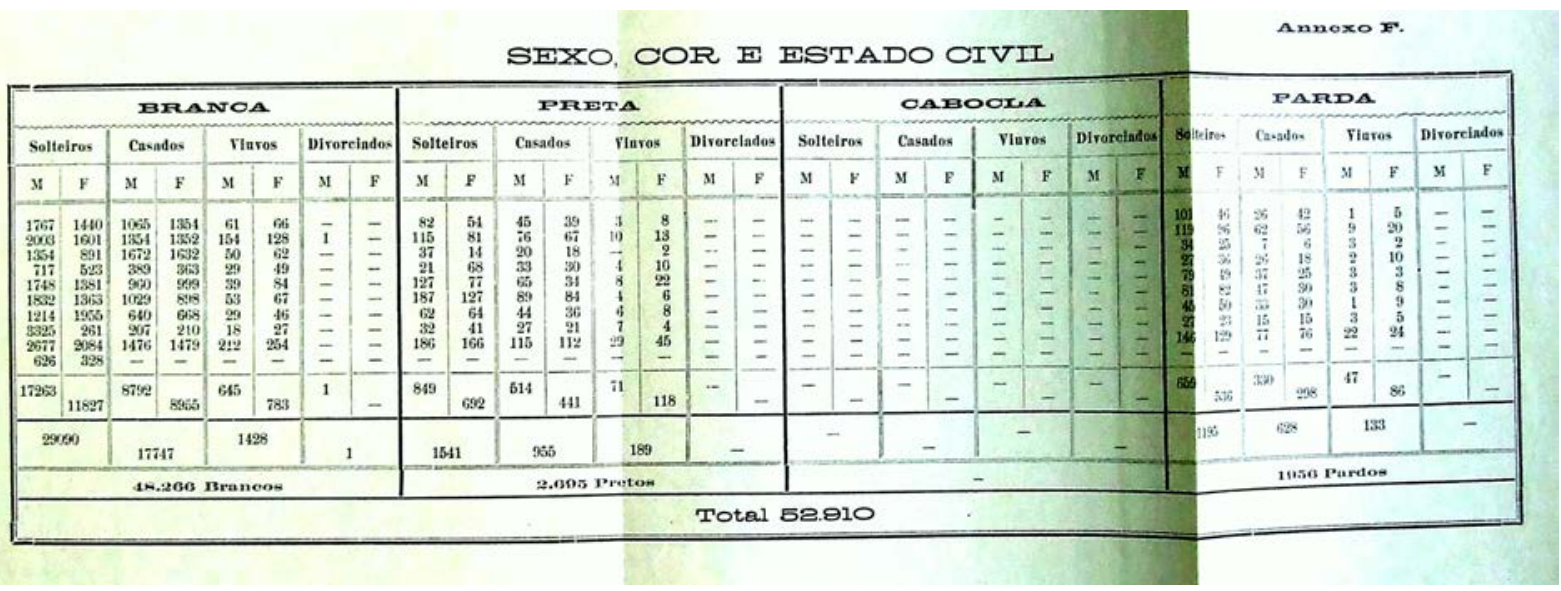

Figura 8: Dados demográficos apresentado no relatório do Intendente Municipal de 1903: a população do município de Ribeirão Preto era de 52.910 habitantes; 48.266 considerados Brancos; 2.695 Pretos; 1.956 pardos; o total de estrangeiros no município era de 33.199, sendo a maioria de imigrantes italianos 27.765. Fonte: APHRP.

é refletida, principalmente, na cobrança do Imposto Predial e de Viação. Segundo a autora, o vereador Francisco Schmidt, integrante da Comissão de Obras da Câmara, chega a estabelecer a multa de 30 mil réis aos proprietários de terrenos que não possuíssem muros e outras edificações de tijolos no interior de lotes do perímetro central da cidade. Com a utilização de novos materiais e técnicas construtivas nesse ambiente urbano de vias calçadas, iluminação e rede de águas e esgotos, o valor do Imposto Predial e de Viação contribui para a exclusão do perímetro central das casas de habitação operárias, fábricas e indústrias.

Segundo Rodrigo Faria (2010), o período de edificações realizadas durante a republica pode ser demarcado simbolicamente pela inauguração do Teatro Carlos Gomes, em 1895, e encerrado com a conclusão do Teatro D. Pedro II em 1930. Durante esse período se inauguram uma série de obras e posturas urbanas que privilegiaram o centro da cidade como alvo de uma transformação burguesa. Isto é reconhecido nas mudanças do antigo largo da Matriz, uma década após a contrução da estação ferroviária a antiga Igreja de taípa é demolida. Logo o largo deixa de ser um espaço cênico de uso sagrado, com toda sua popularidade em dias festivos, para se tornar um espaço de uso recreativo e comercial, mais restrito às classes privilegiadas. ${ }^{24}$

Num trecho do relatório do Intendente Municipal Joaquim Macedo Bittencourt, aparece o seguinte sobre essa região da cidade:

JARDINS PUBLICOS - Ribeirão Preto não tinha até 1911 um jardim público. Dava-se, é certo, este nome a uns amontoados de terra, na Praça 15 de Novembro, que se chamavam canteiros, dispostos sem arte e plantados de gramma que, por falta de trato e de água, raramente verdejava, apezar de manter sempre a municipalidade uma turma de trabalhadores encarregados da sua conservação.

Com esta mesma turma, um pouco angmentada, desmanchou-se na quase totalidade o que havia, fazendo-se um bonito Jardim, de taboleiros rasos, bem dispostos, plantados de grama, de flores e de pequenas árvores de ornamentação.

Num trecho deste jardim não se fez. alteração alguma: rebaixaram-se apenas os canteiros para melhor conservação da gramma e das plantas, ficando, porém, com o mesmo traçado e as mesmas grandes árvores que nelle tinham sido plantadas. Quis-se assim prestar uma justa homenagem ao ilustre cidadão que ofez, o Dr. Augusto Ribeiro de Loyola, talentoso advogado que aqui residiu muitos

24 FARIA, Rodrigo dos Santos. Ribeirão Preto, uma cidade em construção: o discurso da higiene, beleza e disciplina na modernização Entre Rios (1895-1930) (2010). 
annos, prestando sempre o seu concurso a tudo que dizia respeito ao progresso e ao engrandecimento deste municipio. (BITTENCOURT: 1920: 20)

Os usos populares das praças públicas, principalmente dessa praça central da cidade, ícone da busca da "modernidade", são restringidos nos Códigos de Posturas, o que expressa o desejo de segregar os incômodos gerados pelos populares. No titulo IV do Código de Posturas de 1902, que tratava dos costumes públicos, comodidade dos habitantes e dos divertimentos, se tem nos seus artigos 224 e 228 o seguinte:

Ninguém poderá estar nas ruas, praças e outros lugares públicos senão decentemente vestido sob pena de multa de $20 \$ 000$ e ser recolbido a prisão por 24 horas (...) é proibido gritar, salvo para pedir socorro, e bem assim fazer alarido, cantar pelas ruas ou lugares públicos e por qualquer modo perturbar o sossego público. Os infratores incorreram cada um na multa de $20 \$ 000$ e serão detidos por 24 horas, caso não obedeçam a intimação (CÓDIGO DE POSTURAS: 1902: 88-89)

Essa distinção de costumes e comportamentos estabelecida pelo Código de Posturas no espaço central da cidade também irá se ampliar para feição arquitetônica das casas a partir da criação da repartição de obras do município em 1911. Embora ainda não existisse um rigoroso zoneamento aprovado em lei pela Câmara Municipal, a fiscalização das plantas das obras públicas e particulares é realizada pelo engenheiro municipal Antonio Soares Romeo acompanhando a tendência de crescimento fragmentado entre os bairros populares e o centro da cidade. Os projetos que deveriam passar pela aprovação do engenheiro foram avaliados segundo uma divisão da cidade em circunscrições diferentes, estabelecendo para cada uma um padrão de casas obrigatórias que deveria guiar as construções dos empreiteiros.

\section{OBRAS PUBLICAS}

A Camara não tinha repartição de obras quando assumimos a direcção do município. Fora, annos antes, suprimido o cargo de engenheiro municipal e as obras que aqui se faziam, quer publicas quer particulares,não eram submettidas a devida fiscalisação, entregues aquellas a empreiteiros, nem sempre escruppulosos, e estas ao livre arbitrio dos proprietários, que raramente observavam as disposiç̃es do Código de Postura.

Coincidiu esta falta na administração pública com o grande desenvolvimento que tiveram os bairros Villa Tiberio e do Barracão, preferidos para residência dos operários e das classes menos favorecidas da sorte, onde foram construidas muitas casas, que alli ainda se encontram fora do alinhamento das ruas, baixas, sem ventilação e sem luz, as quaes só lenta e difficilmente poderão ser reconstruidas, por falta de recursos de seus donos.

No centro da cidade, embora não fosse tão grande o abuso, edificaram-se também prédios em más condições de hygiene, com material de péssima qualidade e sem architectura.

Se bem que, nesse tempo, a municipalidade não tivesse feito obras, não deixou todavia de soffrer as consequências da desorganização de tão importante serviço, pois que foram de todo perdida as não pequenas importâncias que despendeu em reparo dos prédios municipais (BITTENCOURT: 1920: 28-29)

Dessa forma, enquanto que se asseguraram os bons padrões arquitetônicos no centro da cidade através de reparos, demolições e reconstruções de edifícios com o acompanhamento do engenheiro municipal, as edificações nos bairros operários da Vila Tibério e do Barracão acabam permanecendo a cargo de seus proprietários, que possuíam menos recursos para efetivar tais reformas. A delimitação de vetores urbanos de expansão e crescimento chega a ser, segundo Karla Sanches (2003), alvo de um planejamento da Câmara Municipal, que a operava através de isenções 


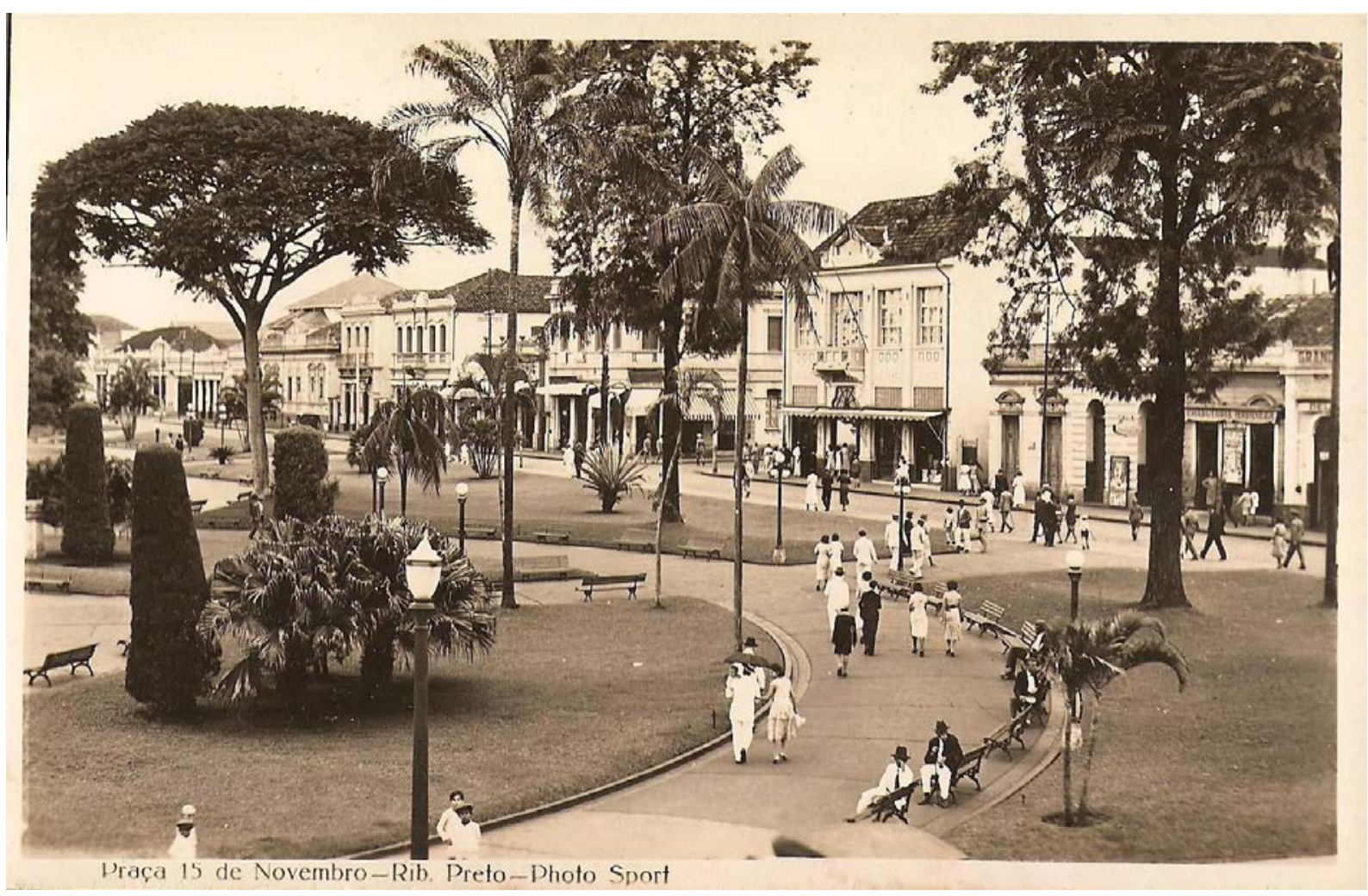

Figura 9: a Praça XV de Novembro, em primeiro plano, o espaço do antigo largo da Matriz, e ao fundo a fachada da rua General Osório, uma das ruas do quadrilátero central a receber a tubulação da rede de água e esgoto. Importante notar o efeito dos Códigos de Posturas sobre a forma de caminhar nesse ambiente privilegiado da cidade. Fonte: APHRP

de impostos no sentido de incentivar as construções em novas ruas abertas e terrenos particulares. A autora apresenta uma resolução que transparece esse zoneamento social na cidade, segundo o livro de registro da Câmara, o projeto de lei de Antonio Uchoa Filho estabelecia a isenção de impostos e quaisquer emolumentos no período de três anos para a construção de casas até o valor de 8 mil réis que se situassem nos bairros além dos ribeirões Preto e Retiro. O teto de 8 mil réis delimitava, portanto, o padrão das moradias que se constituiriam nessa região da cidade, que apesar de pequenas deveriam ainda remeter as plantas e o orçamento da obra para o engenheiro municipal, que avaliaria seus aspectos estéticos e harmoniosos.

Defini-se, portanto, uma politica urbana que, na consciência das suas intençöes claramente delimitadoras de uma cidade salubre, interna ao perímetro dos córregos, transfere para as áreas periféricas todo o ônus que esta urbanização sanitária produ₹: Nos mais afastados locais do Município, próximo ao Barracão dos Imigrantes e outras áreas, como aquelas delimitadas pelo Núcleo Colonial Antônio Prado, estariam sendo edificados equipamentos que não correspondiam aos desejos da burguesia cafeeira, responsável pela modernização da cidade. Representação do indesejável, tais construções e serviços urbanos deveriam localizar-se próximo àqueles cujo convivio social também era indesejável, e, mais que isso, um perigo. Assim, aos imigrantes e trabalhadores, pobres em geral, matadouros, hospitais e cemitérios. Ao nobre burguês urbanizado, teatros, palacetes, praças e vitrines (FARLA: 2010: 90).

Todavia, apesar das taxativas dos Códigos de Posturas no sentido de assegurar a limpeza e a higiene do espaço central da cidade, promovendo inclusive a incorporação de um imaginário referente à salubridade na cabeça de alguns cidadãos. Diversos hábitos antigos não são abandonados, mesmo sob toda a vigilância dos Inspetores de Polícia e em meio aos equipamentos de limpeza. Uma nota matinal no jornal $A$ cidade de um domingo do mês de junho de 1911 transparece esse 
embate entre antigos hábitos arraigados e os novos paradigmas de costumes aspirados por cidadãos que vislumbravam uma nova ordem condizente com os discursos de uma cidade republicana limpa e esterilizada.

A carta do leitor do jornal constrói a seguinte cena na rua General Osório:

\section{NOTAS ALEGRES}

Como um poste de luz electrica, fincado na esquina, permanecia, numa attitude curiosa um jovem, acompanhando com o olhar, toda a extensão da rua, num leve volver do corpo, assim como se usa militarmente dizer nos exercícios da Linha de Tiro: uma oitava á direita.

Ao vê-lo, fiquei curioso também; elle admirava-se do que via e do que eu ignorava, e eu tinha vontade, uma vontade doida de conbecer os seus pensamentos.

Por fim não resisti.

- O meu amigo admirava se de que?

- Si acha que eu me admiro de alguma cousa, vou dizer: Eram 5 horas da tarde, hontem quando estive neste mesmo ponto em que me vê. Lançava os olhares por toda esta rua (era a rua General Ozorio) e foi com grande revolta d'alma que presenciei o pouco zêlo que têm com a hygiene e a limpeza a publica estes proprietários de estabelecimentos commerciaes, (sem ao menos desconfiarem que existe na Câmara uma lei que proibe taes abusos), atirando para a rua, a qualquer hora, papéis, cascas de fructas, lixo, terra, tudo enfim que é imprestável em suas casas e em seus quintaes.

Hoje (ou nunca me dei ao trabalho de verificar ha mais tempo) como vê, para aqui vim, são 9 horas, pode ver no relógio, e daqui tenho apreciado este bello trabalbinho de atirar lixo á rua.

A carroça da limpeza publica acabou de passar ha bocadinho, foi atopetada, cheia até a boca. Pois não lhe digo mais nada, veja como está sujo alli para cima.

- É verdade, tem razão.

- Pois - continuou o meu amigo - acabei de crer que... - Está vendo aquella carrocinha? é da limpeza também, e passa, por aqui, duas ou três vezes por dia. Mas .... assim que acaba de passar, eis novamente a rua completamente suja, e uma rua como esta, meu amigo, de tão grande commercio e maior movimento, por onde passam gentis senhoras e cavalheiros de smarts, bellas crianças de vestidinhos brancos que demandam a escola, uma rua principal assim, que conta com a Casa Allemã e com a paulicéia (aparte o reclame) oh, é preciso ser mais cuidadoso, e a Câmara tendo as suas leis e os seus fiscaes, será fácil conseguir-se tal.

Fiquei satisfeito com o bello pensamento do jovem que deparei na esquina.

Realmente seria uma delicia para quem gosta do asseio, passar pela rua General Ozorio sem perigo de sujar o seu Walk-Ower, ou seu vestidinho branco e, o que é mais, estando seguro de que não corre risco de receber pelas ventas um punhado de cascas de bananas.

Tem razão o jovem, garanto que tem.

A. Jacques. (A CIDADE: 1911: 1)

A imagem da disposição e do funcionamento da Casa Confiança (Figura 10), um estabelecimento comercial de materiais de construção, munições e outros artigos, situado nas imediações da rua General Osório, ilustra os hábitos que haviam sido alvo do enobrecido cidadão preocupado em não sujar o seu Walk-Ower, ou mesmo o belo vestido branco de sua acompanhante de passeios dominicais. A presença de Joaquim Proença da Fonseca, proprietário da venda, ao lado de familiares e funcionários, além da companhia de animais domésticos, contrasta com a postura e as vestimentas das pessoas que circulavam entre os jardins da nova praça XV de Novembro.s

Assim, se vê antigos hábitos sendo impelidos pelos novos costumes impostos pelos Códigos de Posturas, e se estabelece em Ribeirão Preto um imaginário que a dividia entre uma cidade virtuosa e outra carregada de vícios: 
A cidade se modernizava. Os melhoramentos urbanos imprescindiveis para a acomodação de pessoas, como água, luz esgoto e calçamento foram implementados. O centro se tornava, para alguns visitantes, o cartão-postal de Ribeirão Preto, com sua praça, jardim e edifícios públicos. Porém, a mesma modernização que evocavaimagens virtuosas da promissora terra do Oeste, carregava consigo as sementes de outro emblema urbano: a cidade viciada (PAZIANI: 2005:191).

Esse movimento de transformação urbana não se restringia ao espaço central da cidade, promovendo na realidade uma separação entre duas regiões definidas pelos novos bulevares promenades construídos junto aos canais dos ribeirões Preto e Retiro Saudoso. A figura 12, cuja legenda do postal está incorreta, é uma fotografia do canal e avenida sobre rio Retiro, arborizado com suas margens retificadas. Os dois canais nos moldes de bulevares (Figuras 12 e 13) definem os limites da moderna cidade intra-rios. A Avenida do Café, ao longo do leito do rio Retiro, separava o centro da cidade do bairro Campos Elíseos, originário do antigo Núcleo Colonial Antônio Prado. O canal havia sido feito com as pedras de basalto das primeiras pedreiras da cidade, e possuía o seu vertedouro num molde típico dos canais projetados por Saturnino de Brito.

Porém, as obras dessa avenida e canal se estenderam ao longo de toda a Primeira República, construídas ao longo de diferentes gestões municipais e por diversos empreiteiros. No período da Intendência de Joaquim Gusmão, em 1897, sua construção se inicia numa aliança entre Arthur Diederichsen, fazendeiro e construtor, com o então líder político da Câmara Municipal, Francisco Schmidt, o que facilitaria o envolvimento também nas obras de calçamento e construção de pontes sobre os canais.

As obras de retificação e aterramento das várzeas desses rios centrais da cidade envolveram diversos engenheiros, custando centenas de contos ao tesouro da Câmara, além de serem realizadas mediante a cessão de terrenos às companhias e fábricas instaladas em suas margens. A realização do primeiro trecho do cais do ribeirão Preto é coordenada pelo engenheiro Samuel das Neves com o envolvimento de capital da Cia. Mogiana, interessada na posse dos terrenos nos arredores de sua Estação Central. ${ }^{25}$ Nelas é visível a semelhança com alguns sistemas de drenagens que utilizam os

\begin{tabular}{|c|c|c|c|}
\hline into & Construccóes & Reconstrucçóes & Aogmerios o reicrans \\
\hline & 118 & 4 & 18 \\
\hline $\begin{array}{l}1911 \\
1912\end{array}$ & $\begin{array}{l}118 \\
182\end{array}$ & 17 & $\begin{array}{l}18 \\
28\end{array}$ \\
\hline 1913 & 261 & 17 & 31 \\
\hline 9114 & 187 & 21 & 45 \\
\hline 1915 & 109 & 19 & 64 \\
\hline 1916 & 64 & 42 & 63 \\
\hline 1917 & 83 & 8 & 28 \\
\hline 1918 & 23 & 6 & 33 \\
\hline 1919 & 40 & 3 & 21 \\
\hline \multicolumn{2}{|c|}{ Total } & 137 & 339 \\
\hline
\end{tabular}

Figura 10: no relatório da gestão municiapl de 1920 aparecem os números de construções e reformas realizadas durante a década de 1910 em Ribeirão Preto. Fonte: APHRP.

25 Arthur Diederichsen se torna um celebre construtor de pontes sobre o Retiro Saudoso e rio Preto. 
rios como canais a céu aberto e suas vias marginais como vetores de expansão. Os fundos de vales dos rios transformados em avenidas bulevares acabam definindo o desenho urbano demarcado pelo perímetro mais antigo da cidade.

Em 1930, Joaquim Camillo de M. Mattos apresenta a continuidade das obras dessas avenidas:

$$
\text { AVENIDA DO CAFÉ }
$$

Continuam em grande actividade os trabalhos da construção da Avenida do Café e a canalisação dos córregos Ribeirão Preto e Retiro.

A Avenida do Café, que será em breve uma das mais bellas do Estado de São Paulo, já está com os aterros das ruas quase concluidos.

As pontes sobre os córregos do Retiro estão igualmente quase todas concluidas. As balaustradas adeantadissimas. Os canaes dos dois córregos, completamente ultimados, já recebem as águas. Diversas construçẽes estão iniciadas na Avenida do Café. A iniciativa particular em Ribeirão Preto cominha pari-passu com a do poder público. Breve novos construcçöes virão concorrer para o embellezamento da nossa cidade. (MATTOS: 1930: 120)

Já a ocupação ao norte da cidade, numa região mais baixa do território do município, esteve associada à configuração espacial do Núcleo Colonial Antônio Prado, que surgiu do desmembramento de várias glebas da Fazenda Ribeirão Preto Abaixo, pertencente a Vicente José dos Reis. Em 1886, por meio do confisco do Governo Imperial, segundo a lei de terras 1850, aquelas glebas foram transformadas em "terrenos nacionais", e a criação do núcleo permitiu absorção do fluxo migratório e a valorização das terras da zona da Mogiana. Entre 1886 e 1894, o núcleo foi o único, entre as quinze colônias fundadas pelo Império no Estado de São Paulo, que se situava numa área recém aberta pelo café. Visto que a Mogiana já realizava o transporte do produto ao porto de Santos, o Governo Imperial autoriza o estabelecimento de núcleos coloniais nos principais distritos agrícolas próximos à estrada de ferro.

O núcleo foi implantado pelo Governo Imperial numa região baixa do território do município, numa área compreendida pela várzea do ribeirão Preto que possuía baixo valor comercial. Os seus limites faziam fronteira com barreiras naturais dos dois rios perimetrais ao centro e com a ferrovia que cortava a cidade. Os requerentes de lotes na área mais urbanizada deveriam possuir uma profissão urbana de artífice, além de demonstrarem pecúlio para a constituição de oficina ou estabelecimento comercial. A sede do núcleo era a única área que possuía equipamentos urbanos, como o Barracão e uma estação de trem funcionando como hospedaria e administração. Neste Barracão desembarcaram os imigrantes que vinham para Ribeirão Preto realizar o requerimento de seus lotes, ou então se encaminhar às fazendas de café.

Com a entrada do núcleo na malha urbana, a

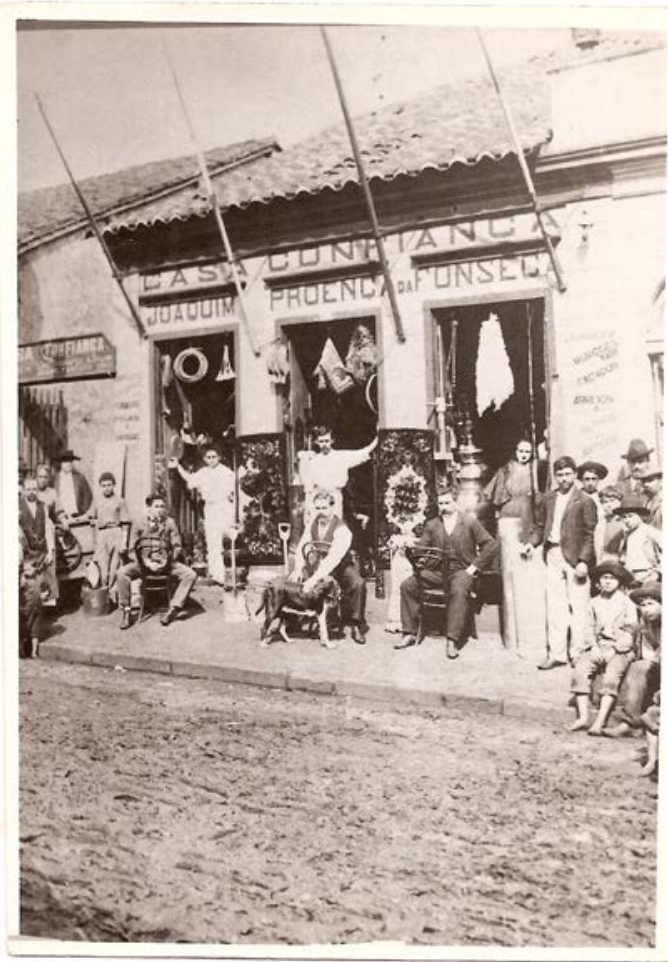

Figura 11: Casa Confiança. Fonte APHRP. 

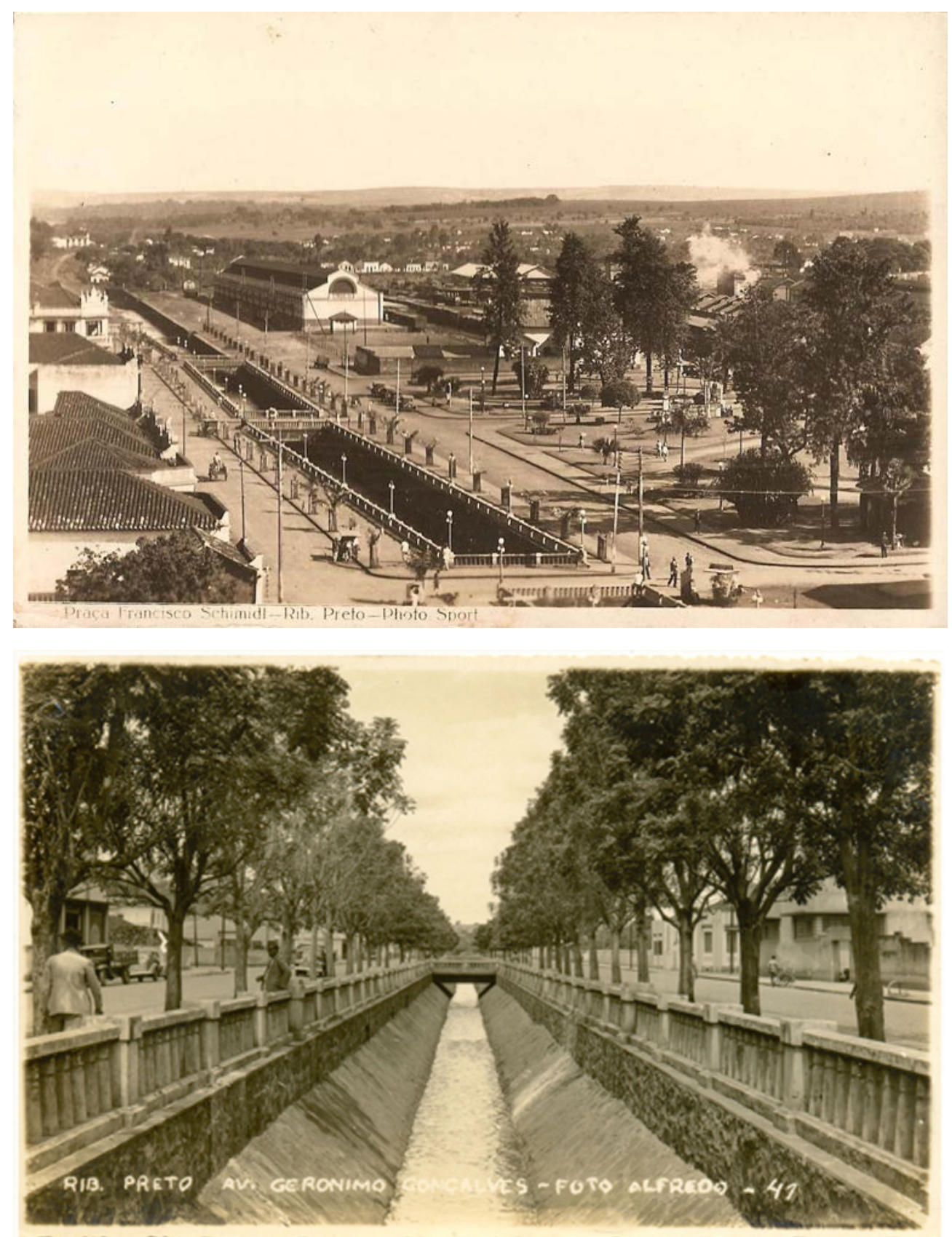

Figura 12 e 13: As duas avenidas construídas sobre os leitos dos rios que passam circundar o centro de Ribeirão Preto. Fonte: APHRP.

cidade de Ribeirão Preto ganha o seguinte desenho:

Surgia, assim, uma cidade pobre, gerada pelos meios de produção da cidade rica, confinada espacialmente dentro do valorizado núcleo original da cidade (simbolo de abastança e prosperidade do município) e as fazendas da zona rural circundante que, na época dispunham de todo o conforto, acabando por se transformar em sedes das grandes empresas agricolas do café. (VALAD ÃO, 1997, p.62)

A construção da cidade moderna é entendida, dessa forma, por um movimento contraditório de criação de um ambiente propício ao cotidiano burguês em oposição aos espaços e ao cotidiano dos bairros populares. A cidade que esteve fora do limite dos rios foi continuamente evitada na ordem das melhorias que orientaram a modernização, com os seus moradores sendo abafados pelos valores burgueses, sobretudo, pelas ações disciplinares de fábricas, da filantropia e 
da polícia.
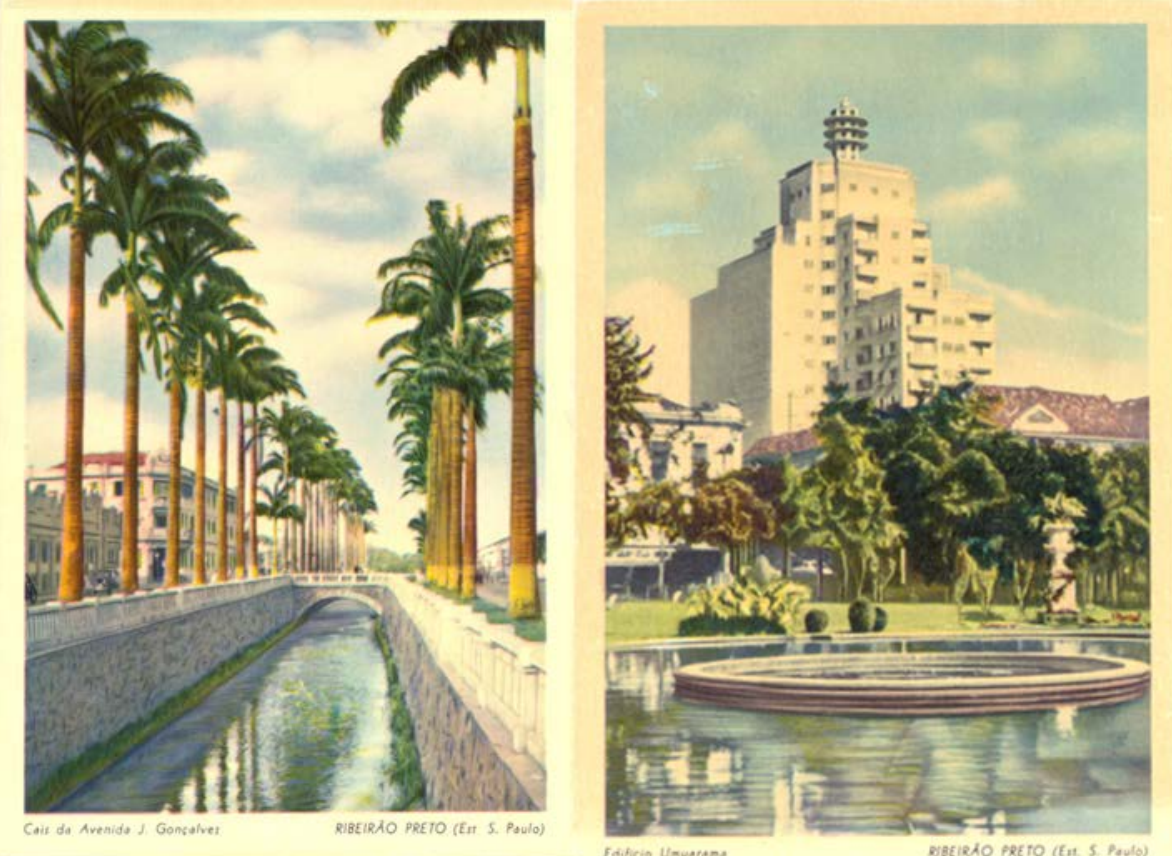

Figura 14 e 15: Os cartões postais se tornam populares no início do século XX pela capacidade que possuíam de comunicar uma representação privilegiada das localidades retratadas. Assim, vemos dois postais da cidade Ribeirão Preto retratando de modo idílico paisagens construídas ao longo da Primeira República. Primeiro o Cais da Avenida J. Gonçalves, vista à montante do rio Preto, com o seu canal retificado junto à linha de palmeiras imperiais e as balaustradas ao estilo das promenades tropicais que eram construídas em diversas cidades em vias da modernização (hoje, porém, bastante modificado e carcomido por reformas). E, segundo a fonte luminosa da praça XV de novembro, local da fundação da cidade, alvo de profundas modificações no sentido de transformar o antigo largo da Matriz considerado pelos Intendentes republicanos como arcaico e colonial. Fonte: APHRP.

\subsection{A construção da rede de água e esgoto.}

Diante de uma crise sanitária que se abateu sobre a vida da população de Ribeirão Preto os prefeitos municipais iniciaram uma serie de ações para aplacar as moléstias que se espalhavam pela cidade. Entre essas medidas de controle sanitário se destacaram aquelas relacionadas a transformação do ambiente urbano da cidade, mas sobretuto a construção da rede de água e esgoto. Na abertura do relatório de Joaquim da Silva Gusmão, apresentado aos vereadores em sessão pública de 1897, aparece sua preocupação paisagística:

\section{Ilustres Cidadãos}

Durante o tempo em que por vossa complacência fui intendente (...) conclui embora imperfeitamente a canalização do Córrego do Retiro, auxiliado (...) pelo zeloso administrador de obras (...) estabeleci o serviço de bigiene e desinfecção municipal, anexando-lhe o de limpeza pública (...) tratei de aproveitar um bábil arboricultor que se encarregasse da (...) educação das mudas de eucaliptos remetidas pelo Governo do Estado; consegui com a influência política do ilustre presidente da edilidade, sementes de arvores que melhor se prestarão para a arborização das ruas e praças onde se fará parques para recreio da população (...). Como vedes duas cousas principalmente ocuparam sempre meu espirito: o saneamento e a hygienne desta cidade, serviços uns bens comescados, outros em véspera de conclusão e outros com esperancas de serem executados.

Saúde e Fraternidade aos Ilustres Cidadãos Tenente Coronel Presidente e mais vereadores.

O Intendente 
No trecho se nota que Joaquim Gusmão se dirigia apenas à população que fazia uso das praças para o recreio, sem referência àqueles que as utilizavam para comércio, mais comum entre ambulantes e agricultores das chácaras do subúrbio da cidade. Porém, apesar dos resquícios de um tratamento nobiliárquico, se ressalta a sua preocupação com a arborização da cidade e a canalização do córrego Retiro, utilizando as mudas de eucaliptos oriundas da aliança política de Francisco Schmidt, então líder político na Câmara Municipal, com governador do estado Peixoto Gomide ${ }^{26}$.

Em meio ainda ao paternalismo, ou aos novos formalismos liberais, se tem outras concepções de paisagem urbana. As boas intenções de Joaquim Gusmão em dar à cidade um novo plano de ruas e praças arborizadas recaem, inevitavelmente, no ambíguo processo de modernização da cidade. A sua preocupação em relação à educação das plantas e ao bom arejamento de espaços remete às teorias que embasaram algumas reformas urbanas do final do século XIX, como no caso dos trabalhos do ainda jovem engenheiro Saturnino de Brito, chefe do segundo distrito da Comissão de Saneamento do Estado de São Paulo.

Como integrante da Comissão, Brito critica a feição mórbida das cidades do Interior Paulista, ainda sem sistemas eficientes de drenagem e abastecimento d'água, propondo Planos Gerais de Saneamento. O município de Campinas, na ocasião, passara por três surtos epidêmicos consecutivos, entre 1890 e 1896, fazendo com que Brito elaborasse as correções no seu sistema de drenagem e abastecimento de água que, além de contribuírem contra as epidemias, redefiniram a forma da cidade, com os canais a céu aberto e avenidas arborizadas dotando esses caminhos de áreas verdes.

Nesse momento, o engenheiro estava envolto na Teoria dos Meios, buscando compreender o nível de reciprocidade entre os seres vivos e o meio físico. Para ele, esse entendimento era o cerne dos problemas sanitários, ou seja, entender a cidade como um organismo coletivo de homens, onde o restabelecimento da saúde dos indivíduos estaria no âmbito de um saneamento urbano educativo. ${ }^{27}$ Segundo Lapa (2008), porém, a cidade de Campinas, no contexto das intervenções de Saturnino de Brito, atravessava um período de transição entre uma sociedade escravocrata para outra liberal baseada no trabalho livre. Desse modo, o confronto entre esta simultaneidade transparecia as aspirações burguesas de camuflar a cidade senhorial. Os planos urbanos de Brito não escapariam, assim, àquela ambiguidade da instrumentalização paternalista da técnica e da beleza urbana. As reformas efetuadas pelo engenheiro também serviriam ao objetivo burguês de transformar o antigo cenário da cidade.

Em Ribeirão Preto, após a visita dos engenheiros da Comissão de Saneamento e do Serviço Sanitário do Estado, se iniciam as ações sanitárias que irão perdurar ao longo das três primeiras

26 WALKER, T. W.; BARBOSA, A. de S. Dos coronéis a metrópole, fios e tramas da sociedade e da política em Ribeirão Preto no século XX. Palavra Mágica: Ribeirão Preto, 2000.

27 ANDRADE, Carlos R.M. de. Projetos e obras do Eng. Saturnino de Brito para Campinas em fins do século XIX. Oculum Ensaios. Revista de Arquitetura e Urbanismo. n.2 (2002), Campinas. 
décadas do século XX. O objetivo era desmanchar tudo aquilo que era apontado como insalubre através de medidas de vigilância com a criação dos órgãos de Inspeção Sanitária e Serviço de Higiene, que passam a realizar as visitações domésticas à população.

\section{Hygiene Publica}

Alguns casos de febre amarella e muitos outros de variola que se deram ter se iam propagado pela cidade se não fosse o esforço, zelo e dedicação do digno Delegado de Hygiene Dr. Francisco Augusto Cesar, a quem se deve também a mais perfeita e completa fiscalisação domiciliária (...) onde é grande a aglomeração de pessoas procedentes de diversos pontos atacados por moléstias epidémicas e contagiosas. O aparecimento da variola nas fazendas (...) foi occazionado pela chegada de immigrantes vindos para aquellas sem a necessária observação na hospedaria de São Paulo. A vacinação aqui foi feita com a máxima regularidade. (CAMARA MUNICIPAL, 1902:12)

Sidney Chalhoub (1996), pesquisando os papéis da Junta Central de Higiene do Rio de Janeiro, dá pistas das concepções dos sujeitos por trás dessas ações sanitárias ao final do século XIX. O autor remonta à formação daquilo que ele chama de Ideologia da Higiene, propagada como uma administração competente e técnica da insalubridade, ocultando o sentido classista da associação entre os cortiços e a febre amarela. Imaginário que fundamentou a eliminação dos cortiços e o afastamento das "classes perigosas" do centro do Rio de Janeiro e de diversas cidades brasileiras.

A febre amarela era considerada um flagelo de imigrantes, por isso ela foi priorizada pelos cientistas da higiene em detrimento, por exemplo, da tuberculose, que acometia de forma grave a população negra do Rio de Janeiro. As políticas de intervenções, segundo Chalhoub (1996), obedeciam ao mal confessado objetivo de tornar o ambiente urbano salubre a um determinado setor da população. Ao combater doenças hostis à população branca, restava esperar que a miscigenação promovesse a eliminação da herança africana da sociedade brasileira.

O episódio, em 1893, do combate ao cortiço Cabeça de Porco é um exemplo paradigmático. Após diversas intimações de despejo da Intendência Municipal de Barata Ribeiro, a desocupação do cortiço é cumprida mediante toda uma empreitada liderada pelos médicos e engenheiros municipais. ${ }^{28} \mathrm{O}$ destino dos moradores foi a subida ao Morro da Providência, que mais tarde ainda receberia os soldados egressos da campanha de Canudos. O episódio marcou o fim da era dos cortiços no Rio de Janeiro para a entrada no século das favelas.

Em Ribeirão Preto, Karla Sanches (2003) aponta que os Códigos de Posturas do município, elaborados durante a Primeira República, eram muito influenciados pelo Código Sanitário do Estado de São Paulo, possuindo uma forte influência higienista. Esses Códigos apresentavam diretrizes e regulamentações com o seguinte teor:

O capitulo III, tratando sobre fabricas e oficinas, vedava a instalação, dentro do quadro central da cidade, de fabricas de sabão, óleos, velas de sebo, curtumes, máquinas de beneficiar café, arroz on milho, depósitos de sal em grande quantidade e outros estabelecimentos que, pelas matérias primas, seus produtos e combustiveis empregados, exalassem vapores que pudessem ser nocivos à atmosfera, prejudicassem a salubridade ou incomodassem a vizinhança (SANCHES: 2003: 197).

28 Ver em Chalhoub, S. op. cit. 
Os Códigos de Posturas de Ribeirão Preto irão proibir a construção de estalagens e cortiços, além de regulamentar a construção de vilas operárias, que só poderiam ser levantadas em grupos de duas, com uma habitação por família, sendo necessária uma sèria de cômodos para evitar a promiscuidade. Ademais, o Código de 1921, seguindo o Código Sanitário do Estado de São Paulo, no capítulo sobre "habitações das classes pobres", definia que as vilas operárias deveriam ser construídas fora da aglomeração urbana.

ART. 103 Nas construcções e casas para habitação de familia de operários, fora do perimetro urbano da $1^{\circ}$ e $2^{\circ}$ zonas, serão observadas as prescipcóes seguintes: a) A altura minima das paredes, contada do pavimento até o frechal, será de 3 metros. O pavimento poderá ser de madeira ou ladrilhado. No primeiro caso ficará pelo menos 50 centímetros acima da superficie do solo, que deverá ser cimentado ou ladrilhado, sendo o porão convenientemente ventilado. (...)

ART. 104 Quando forem construídas varias casas unidas, as paredes divisórias terão a espessura minima de 30 centimetros e irão até o telhado, sendo os respectivos terrenos separados internamente por cercas ou muros. Deverão ser providas de instalação sanitária consistente em encanamento e distribuição de água e latrina com ligação conveniente a rede de exgottos.

ART. 105 Não se comprehende como cortiço as habitações de familias pobres com mais de um repartimento, cosinha e exgotto em separado, observadas as prescriçôes de bygiene e asseio dos regulamentos sanitários. (...)

$\mathbb{S u ́ n i c o ~ - ~ e ́ ~ e x p r e s s a m e n t e ~ p r o b i b i d a ~ a ~ c o n s t r u c ̧ a ̃ o ~ d e ~ e s t a l a g e n s ~ o u ~ c o r t i c ̧ o s ~ ( C O ́ D I G O ~ D E ~}$ POSTURAS: 1921:45-46)

Chega-se assim à discussão sobre o nascimento da medicina social de Michel Foucault (1979), sendo algo que teria nascido na França, em fins do século XVIII, frente ao fenômeno da urbanização. Paris, a grande cidade francesa, não possuía ainda uma unidade territorial, mas um emaranhado de territórios heterogêneos e poderes rivais. A unificação do poder urbano se colocava então com a necessidade de tornar a cidade um corpo homogêneo. Os motivos dessa demanda eram desde a indústria nascente, que faz do espaço urbano não só um lugar de mercado, mas também de produção, até o aparecimento de uma população operária pobre, aumentando de maneira drástica as tensões políticas.

As relações citadinas não estariam mais, a partir de então, em pé de equivalência, mas, cada vez mais, numa espécie de oposição entre ricos e pobres, o que leva ao desenvolvimento do medo e da angústia frente às cidades. As medidas tomadas para esse enfrentamento procuravam reestabelecer intervenções médicas da quarentena. Ou seja, um plano de urgência, que existia desde a Idade Média, aplicado em momentos de Peste, dispondo de diretrizes como a interrupção do movimento na cidade e a manutenção das pessoas em suas casas sob a vigilância de inspetores de bairros. Foucault (1979) chama esse processo de esquadrinhamento do espaço urbano.

Assim, surgem estudos sobre a posição das fontes e dos esgotos urbanos para evitar o despejo de águas pútridas em mananciais puros, como no caso do $1^{\circ}$ plano hidrográfico de Paris de 1742, que descrevia os lugares para dragagem de água que não tinham sido atingidos por esgotos, além organizar uma polícia da vida fluvial.

A medicina urbana não é verdadeiramente uma medicina dos homens, corpos e organismos, mas uma medicina das coisas: ar, água, decomposições, fermentos; uma medicina das condições de vida e meio de existência. Esta medicina das coisas já delineia, sem empregar ainda a palavra, a noção de meio que os naturalistas do final do século XV III, como Cuvier, desenvolverão [...] com ela aparece, 
pouco antes da Revolução Francesa, uma noção que terá uma importância considerável para a medicina social; a noção de salubridade [...] Salubridade é a base material e social capaz, de assegurar a melhor saúde possivel dos indivíduos. É é correlativamente a ela que aparece a noção de higiene pública, técnica de controle e de modificação dos elementos materiais do meio que são suscetiveis de favorecer ou, ao contrario, prejudicar a saúde [...] A bigiene publica - no sec. XIX noção essencial da medicina social francesa - é o controle político-cientifico deste meio (FOUCAULT: 1979: 93).

No relatório do Intendente Municipal Dr. Manoel Aureliano Gusmão transparece esse tipo de controle do território urbano de Ribeirão Preto, como na inquietação demonstrada contra o adensamento de casas coletivas. A cidade se tornara o destino de inúmeros estrangeiros, sendo esses cortiços e pensões opções de moradia de imigrantes que não se dirigiam às colônias de fazendas ou aos lotes rurais do Núcleo Colonial Antonio Prado. O rápido crescimento populacional e urbano criaram possibilidades de trabalhos na região central, como no comércio de ambulantes ou mesmo nas obras de melhoramentos contra epidemias:

O serviço sanitário, a cargo do intelligente e zeloso delegado de bygiene Dr. Ponciano Cabral (...) tem sido executado de modo irreprehensivel, fasendo-se, com a precisa regularidade, as visitas domiciliares (principalmente as casas de habitação collectiva e de grande accumulação de gente (...) a limpeza das ruas e praças, a remoção diária do lixo e também das águas servidas, na parte da cidade onde ainda não chegou a rede de exgottos (CAMARA MUNICIPAL, 1903:14).

No relatório da gestão municipal de 1897 é apresentado um déficit de gastos de mais de dois contos de réis em relação à receita da Câmara em virtude da anormalidade da vida sanitária da cidade. Algo que leva à aprovação pelos vereadores das resoluções de $n^{\circ} 03, n^{\circ} 04$ e n 05 , dando à Intendência Municipal as prerrogativas das ações sanitárias:

Devido à anormalidade que infelizmente se deu na vida sanitária deste Município, tornando-se de ingente necessidade o desequilíbrio das verbas rubricadas no orçamento vigente, como bem reconheceu esta Câmara Municipal votando as resoluções $n^{\circ}$ 3, 4 e 5, armando essa Intendência de meios de ação para poder cercear a população deste município de verdadeiras garantias sanitárias contra a invasão da febre amarela que então ameaçou esta Cidade. [...] quanto espinhoso cargo de Intendente Municipal, continuastes as obras de saneamento dos córregos, rasgando, retificando e alargando seus leitos, aterrando suas margens e saneando os extensos pantanaes que circundam esta Cidade, por meio de valletas e drenos que encaminham para os referidos córregos as águas estagnadas. (CAMARA MUNICIPAL, 1897:9).

A regulamentação desses serviços de higiene se insere num processo de racionalização enfatizado pelo regime republicano com a criação de repartições de controle social num consórcio entre poder municipal e estadual. ${ }^{29}$ Termos referentes ao progresso e à salubridade tornam-se centrais nos discursos dos Intendentes Municipais, surgindo uma nova linguagem associada à reconstrução da cidade. Ademais, em virtude da onerosa construção da rede de água e esgoto, a Câmara Municipal acaba bastante endividada.

Karla Sanches (2003) aponta que até 1898 as Comissões de Obras e Posturas eram as únicas repartições públicas responsáveis pelo ordenamento dos melhoramentos urbanos de Ribeirão Preto. Porém, em 1899, com o intuito de aumentar a estrutura da administração dos serviços urbanos, o Decreto Municipal no 32 cria a Repartição de Obras, Águas e Esgotos, composta por um engenheiro chefe, dois auxiliares oficiais, um guarda, um feitor, três pedreiros e nove trabalhadores.

29 Ver o capítulo Higiene \& Saúde Pública de LAPA, J.R do A. Cidade, os cantos e os andros. pp.183-215. 
O Código de Posturas de 1902 passa, então, a estabelecer o seguinte:

\section{Aguas e Esgotos}

Art.95 - Todos os prédios terão conveniente canalização de água, de modo a disporem de suficiente quantidade deste liquido para todos os misteres.

Art. 96 - em todos os prédios serão convenientemente instaladas as latrinas que forem necessárias, a juízo dos proprietários, devendo ser todas ligadas à rede geral de esgotos da cidade.

Art.97 - Em tudo quanto disser respeito ao serviço de canalização de água, instalação de latrinas e expedição de águas servidas, observar-se-á o disposto no regulamento já votado pela Câmara para a Repartição de Agua e Esgoto (lei n.6).

As latrinas deverão ser construídas conforme o código sanitário do estado. (Código de Posturas, 1902)

Entretanto, na construção da rede de água e esgotos, é possível perceber uma mesma tendência segregacionista da localização dos melhoramentos urbanos. A rede de abastecimento d'água é implantada de forma prioritária na região central da cidade, estando mais associada ao imaginário da rede como algo essencial ao ambiente urbano moderno, necessária para por fim ao acúmulo de fossas e à estagnação de águas geradas pela falta de um sistema de escoamento. A construção da rede encontrava obstáculos na falta de recursos financeiros, levando a Câmara Municipal a contrair empréstimos para aplicar na sua construção. O contrato com o Governo do Estado é contemporâneo ao pedido de edificação do Teatro Carlos Gomes, realizado pelos mesmos vereadores Schmidt e Diederichsen, num esforço conjunto para solucionar a questão das águas. A vida ao redor da praça XV poderia então ser desfrutada no flanar entre vitrines que ofereciam produtos importados, ou no interior dos sobrados e palacetes já com os equipamentos hidráulicos instalados.

Em 1895, as condições sanitárias e de infraestrutura na cidade são analisadas pela Comissão de Saneamento do Estado de São Paulo, que aponta as obras em construção: o calçamento das ruas e sarjetas para o escoamento de águas fluviais, a limpeza e drenagem de terrenos marginais ao ribeirão que banha a cidade, a organização de serviços de remoção de lixo das ruas e casas, além do esgotamento das águas servidas. O traçado da canalização de abastecimento de água apresentado pela Comissão de Saneamento define o perímetro da realização da maioria desses melhoramentos urbanos ao discriminar as ruas que receberiam a tubulação da rede:

O encanamento mestre, de 0.5 de diâmetro, da rede de distribuição partira do reservatório percorrendo a rua Ruy Barbosa até o seu cruz̧amento com a Saldanba Marinho, onde ficarão assentados os tubos de 0,12 até a rua do Comercio. Esta rua terá também para seu abastecimento, encanamento de 0,12 até a rua 7 de Setembro, bem como esta rua e a Barão do Amazonas no trecho comprehendido entre as Ruy Barbosa e Commercio. A rua Américo Brasiliense será servida por canalização de 0,10 desde a rua 7 de setembro até a E.F. Mogyana. Nas ruas Lfayete e General Ozorio serão estabelecidos tubos de 0,76 (appud FARIA, 2010:79).

A rede passaria pelas principais ruas do centro cidade, formando o contorno do seu quadrilátero: a rua Ruy Barbosa, onde se encontra o reservatório, numa porção mais alta em relação à Praça XV e aos córregos; a rua Saldanha Marinho, paralela ao cais do ribeirão Preto, endereço de hotéis que serviam à Estação de Trens; a rua do Comércio, de ocupação mais antiga, contigua ao córrego do retiro e, por fim, a rua 7 de Setembro, que fecha o contorno estabelecido pela rede de abastecimento d'água. No meio dessa quadrícula passará a tubulação da rua General Osório, 


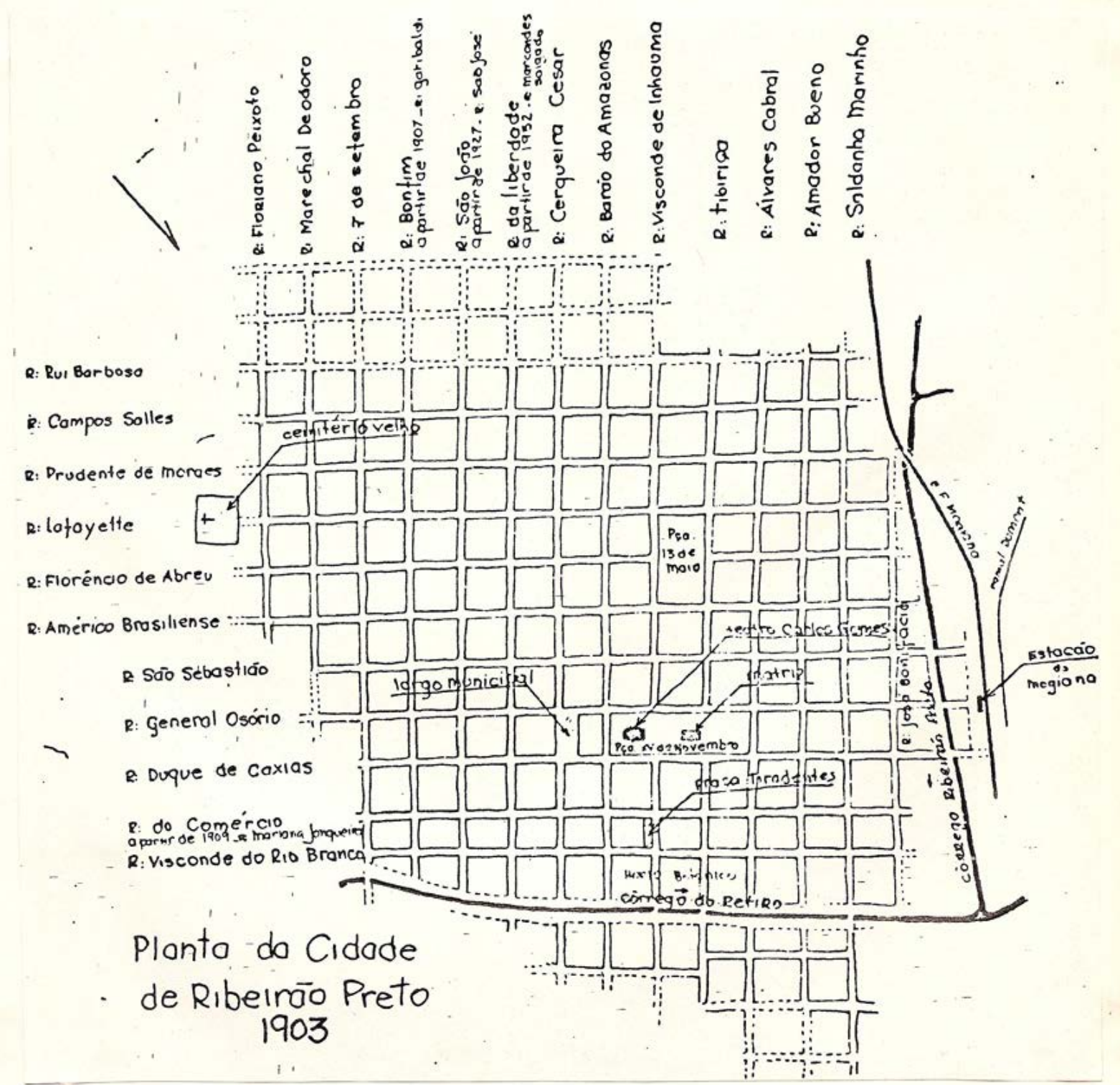

Mapa 3: Nele é possível identificar a quadrícula formada pela rede de abastecimento de água (ruas: Ruy Barbosa; Saldanha marinho; rua do Comércio e Sete de Setembro), além de identificar a rua General Osório cortando o centro no sentido da Estação . Fonte APHRP.

endereço de lojas importadoras, bancos e casas comissárias, atravessando toda a fachada da praça XV em direção a Estação Ferroviária.

Para além desse perímetro urbano, pouco se estabelece como programa de infraestrutura de abastecimento d'água e esgotamento sanitário. No inicio do século XX, a rede quase não se expande ao outro lado da cidade, ficando mais restrita aos limites estabelecidos pelos córregos, apesar das previsões da Comissão de Saneamento em 1897:

Abastecimento d'água - Duas passagens sobre o córrego do Retiro foram construidas (...) com o rápido desenvolvimento da cidade e o augmento progressivo das novas edificaçoes, a turma, encarregada da conservação e de fazer novas ligações, será sempre ocupada, e conviria antes de fazer-se a medição final dos trabalhos, que estão a cargo do empreiteiro engenheiro Augusto Ramos, assentar por conta da construção, mais uma linha de tubos de 3" com alguns ramais para servir o arrabalde do Barracão, o qual em futuro próximo poderá tornar-se um bairro importante da cidade, pela superfície que ocupa, e que é quase equivalente a da cidade propriamente dita. (CSESP, 1897:53). 
Entretanto, a extensão da rede de água e esgoto para o bairro Barracão (antigo Núcleo Colonial) não aparece nos discursos dos Intendentes Municipais, mais preocupados com a construção de outros espaços da cidade. Essa política urbana delimita, portanto, os espaços salubres internos ao perímetro dos córregos, transferindo para as áreas periféricas todo o ônus que esta urbanização sanitária produzia. No relatório do Intendente Municipal de 1909 vemos uma polêmica envolvendo a municipalidade e a Empresa de Água a respeito da ampliação da rede de esgoto para a Vila Tibério, algo que estava preestabelecido no contrato de arrendamento do serviço. O ofício do Prefeito Municipal J. P. da Veiga Miranda diria:

Approveitando a opportunidade, lembro a V.S. a necessidade inadiável de que a Empreza dê cumprimento as seguinte disposições contractuaes:

Clausula H-estabelecer a rede de exgottos a Villa Tibério, cujas ruas já tem 10 predios em cada 100 metros (VEIGA MIRANDA: 1909: 61)

O prolongamento, entretanto, é adiado nessa ocasião em virtude da ausência, segundo o gerente da empresa, de uma planta cadastral da cidade, não deixando claro, em sua resposta, se esse prolongamento seria financeiramente interessante para a Empresa.

Clausula H: installar a rede de exgotos em Villa Tibério nos trechos de ruas que tiverem prédios em cada 100 metros: a existência de uma plannta cadastral da cidade muito facilitaria a esta administração o cumprimento dessa clausula, pois outro não é o seu fim senão promover o desenvolvimento da renda da Empreza, com aproveitameito público (VEIGA MIRANDA: 1909: 63)

No relatório do Intendente de 1902, Joaquim Alfredo da Siqueira, se tem o processo do arrendamento do serviço de águas e esgotos a Empresa, momento em Flávio de Mendonça Uchoa, como gerente dos negócios da Família Prado, cria a Cia. Água e Esgoto. Após firmar compromissos financeiros com o Governo do Estado, o Intendente Alfredo Siqueira não finaliza a rede de água e esgoto, fazendo então a abertura de um edital de concorrência para a realização das obras. Um contrato é firmado com Manuel P. Monteiro Tapajós que, em 1894, havia sido engenheiro ajudante nas Cidades do Interior pela Comissão de Saneamento do Estado de São Paulo. Porém, como também não a conclui, propõe, e a Câmara Municipal aceita, que o contrato fosse transferido ao engenheiro Flávio de M. Uchôa.

A criação da Cia. Água e Esgotos de Ribeirão Preto passa, portanto, pelos laços pessoais que os engenheiros, prefeitos e vereadores haviam constituído ao longo de suas trajetórias na cidade. O relatório de Joaquim Alfredo da Siqueira expõe os compromissos, concessões e as dívidas do município:

(...) esta Câmara ao ser empossada assumia o compromisso de divida passiva no valor de 96 contos de réis (...) Não constava do balanço de 1898 a divida que esta Câmara tem com Governo do Estado, em virtude do fornecimento de parte do material para a rede de esgotos e o serviço completo de abastecimento d'água. Para a liquidação dessa divida tem a Câmara o pražo de 50 anos devendo os pagamentos começarem em 1904 (...)

\section{Rede de Esgotos}

Nos últimos mezes de 1898 tendo o Governo do Estado fornecido a esta municipalidade, os canos necessários para a inauguração de uma rede de exgottos (...) a Câmara deu se pressa por convocar por edital concorrentes (...) e visando a necessidade publica contractar no mês de Margo de 1899 com 
o ilustre Dr. Manuel Tapajós o serviço da rede de exgottos sem orçamento prévio de valor total da obra (...) estando a terminar-se o prazo (...) o Dr. Manuel Tapajós, não podendo por motivos (...) de força maior levá-lo a efeito, propôs e a Câmara aceitou que o contrato fosse transferido em idênticas condições ao distinto engenheiro Dr. Flávio de Mendonça Uchoa, concluidos (...) os trabalhos necessários a instalação da rede de esgoto ascendendo a 525 contos a importância total do que deve ser pago ao Dr. Flávio Uchoa pelos cofres da municipalidade (CAMARA MUNICIPAL, 1902:7).

A propalada boa administração municipal na realidade encobria uma função institucional que a Câmara Municipal assume se endividando ao capitalizar empresas privadas. Isso se dá pela circulação dos mesmos agentes entre esferas públicas e privadas como: o Governo do Estado, a Comissão de Saneamento, a Cia. Mechanica, a Cia. Mogyana de Estradas de Ferro e, por fim, a Empresa de Água e Exgotto de Ribeirão Preto. Em 1903, o Intendente Municipal, Manuel Aureliano Gusmão apresenta nas Finanças da Câmara Municipal o pagamento de mais de trezentos contos de réis ao engenheiro local Flávio de M. Uchôa. Esta dívida consumia boa parte da receita anual do Município, que girava em torno de quinhentos contos de réis. Entretanto, a execução de outras obras para completar a drenagem e o saneamento da cidade é anunciada com entusiasmo pelo Intendente em exercício no ano de 1905:

\section{Melhoramentos e Obras}

Apesar do muito que já fizeram as passadas administraçoes no sentido de melhorar as condições de salubridade e comodidade de nossa cidade tão justamente reputada a Capital do Oeste, todavia, nela muito bá que se fazer ainda. Cidade Nova, nascida como por encanto das matas ubérrimas do Estado de São Paulo, pelo esforço dos denodados lavradores paulistas (...) a nossa cidade não oferece ainda aos seus habitantes as desejáveis condições de asseio e embellezamento a que tem direito (...) embellezala por meio de obras de reconbecida commodidade publica deve ser d'ora avante o escopo de uma bem intencionada administração municipal, já que temos a ventura de possuir funcionando com regularidade um bom serviço de iluminação e de abastecimento de água e exgotos. (CAMARA MUNICIPAL, 1905:4).

Os serviços de iluminação e abastecimento de água e esgoto, apesar da "bem intencionada administração municipal", eram geridos por empresas privadas, numa fragmentação da gerência dos aparelhos urbanos que contrariava a noção administrativa dos Planos de Conjunto de Saturnino de Brito. A criação da Empresa de Água e Exgottos de Ribeirão Preto exemplifica o funcionamento ambíguo das administrações locais da República Velha.

Em meio aos novos serviços urbanos, aos interesses políticos na Câmara Municipal e à produção material da cidade, o arrendamento da rede de água e esgoto é feito ao mesmo engenheiro de sua construção. O contrato de 35 anos com a municipalidade é absorvido por uma Sociedade Anônima sediada em São Paulo, fazendo dos papéis da Empresa de Água e Exgottos parte de seus negócios na cidade.

Logo, o abastecimento de água passa a ser feito com mudanças na sua antiga tabela de preços, apontando diferenças bastante elevadas.

Como se vê (...) a diferença entre as taxas antigas $e$ as atuais é bastante elevada, ficando a população relativamente muito sobrecarregada com as modernas contribuições: Isso fazia crer que o novo systema de cobrança das taxas de água e exgottos levantaria clamores gerais.

Tal, porem, felizmente não sucedeu, e um ou outro incidente havido foi prudentemente resolvido pela Prefeitura, efficazmente auxiliada pelo Dr. Theodomiro Uchoa, gerente da empresa, tendo-se procurado nessas ocasiões alliar os interesses do publico aos dos empresários. (CAMMARA MUNICIPAL, 
1905:14).

Essa elevação das taxa de água acaba sendo alvo de reclamações da população à municipalidade, que repassa os termos do antigo contrato à Empresa:

Finalmente torna-se preciso, para os effeitos do art. 40, a apresentação a Câmara dos balanços e contas da Empreza que deverá redusir as taxas de águas e exgotos desde que as suas rendas excedem a porcentagem alli determinada. (VEIGA MIRANDA: 1909: 61)

Algo que é veementemente recusado pelo diretor da Empresa:

Ora, o capital da Empreza sendo de 1.426:866\$522 rs. fácil é ver que muito longe ainda está a situação da Empreza de permitir a reducção de taxas. Com effeito, de accordo com o art. 40 do seu contracto, só quando auferir a Empreza uma renda liquida de 12\%, além de 3\% para fundo de reserva e mais 3\% para obras novas, poderá ter logar a reducção de Taxas a que V.Ex. se refere; entretanto mesmo a renda bruta da Empresa pouco excede 10\%, o que fazprever que nem a $8 \%$ attingirá a renda liquida (VEIGA MIRANDA: 1909: 63)

A ambiguidade entre interesses públicos e privados está no cerne do que toca ao arrendamento da rede de água e esgoto em Ribeirão Preto. A sua construção passou tanto pelos desejos e interesses da elite local de dotar o centro da cidade com aquele moderno equipamento, quanto pela necessidade de prover a salubridade urbana. Nos discursos dos Intendentes Municipais existe um emaranhado de referências a novas ideologias, práticas e técnicas modernas: uma névoa no ambiente político e social da Primeira República no momento da chegada dos profissionais engenheiros na cidade. Alguns destes profissionais atuaram a contrapelo daquelas estruturas herdadas do Império. Outros, porém, se associaram às relações de apadrinhamento com os potentados locais.

\subsection{A política na cidade republicana.}

As ambiguidades da Cãmara Municipal em relação a Empresa de Água tinham origem na política praticada durante a Primeira República. Uma política dominada pelas oligarquias rurais num jogo de apoio à autoridade central em troca de poderes nas instanciais de governos estaduais e locais. Os eleitores, nessa situação, mesmo com o fim do voto censitário, permaneciam pequenos, girando em torno de $4 \%$ da população, sendo bastante manipulados pelos caciques políticos locais. Os partidos nacionais do Segundo Reinado - Liberal e Conservador - desapareceram sem que, no entanto, fossem substituídos por um único Partido Republicano que abrangesse o país inteiro. As classes urbanas, apesar de crescentes, eram mantidas fora da política.

Em suma, Darrel Levi (1977: 277) define essa transição da Monarquia à República da seguinte forma:

As diferenças primarias entre o Império e a Primeira República não eram, assim, de ideologia (exceto em um senso retórico muito abusado) nem de sufrágio, mas de estrutura. Em lugar do poder moderador, surgin a "politica dos governadores", reuniōes de chefes politicos estaduais e o presidente titular, para determinar a sucessão presidencial. O coronelismo tomou o lugar dos partidos imperiais como meio - embora muito impreciso - de integrar localidades e regiöes dentro da estrutura política nacional. A característica principal da Primeira República foi a descentralização, baseada na amplamente apoiada demanda pelos direitos dos estados, que havia solapado o Império. Ao contrário da liderança imperial, os chefes da Primeira República deram reconbecimento político à mudança na 
vida econômica brasileira causada pelo desenvolvimento da economia do café, no centro-sul do Brasil. Com apenas três excepções, no período de 1894 a 1930, os presidentes do Brasil eram ou de São Paulo, ou de Minas Gerais, e a politica geralmente favorecia as necessidades dos interesses do café.

Tal arranjo político e econômico se estruturara por volta de 1894 ao final dos governos dos generais militares, quando se inicia a consolidação dessa ordem republicana a partir da presidência de Prudente de Morais. A ruptura dessa coalizão das oligarquias estaduais no comando da política nacional só ocorrerá ao final dos governos de Arthur Bernardes e Washington Luis na década de 1920. A Primeira República nesse final passa a ser assediada por classes urbanas, como os tenentes, e um grupo de fazendeiros se afasta dos presidentes em virtude do abandono das políticas cafeeiras.

Ribeirão Preto, nesse contexto, sofre basicamente dois influxos: a expansão da economia capitalista sobre as suas terras com a chegada de famílias poderosas para plantar café e, mais tarde, diante da Política dos Governadores, uma pressão sobre a elite política local pela nomeação das candidaturas aos cargos eletivos republicanos. Este segundo influxo será, posteriormente, uma das razões do início das clivagens no Diretório Municipal do PRP, ou mesmo entre os vereadores da Câmara. Algo que se inicia após o final do governo de Floriano Peixoto e início dos governos civis dos paulistas Prudente de Morais (1894-1898) e Campos Sales (1898-1902).

A tônica política na Câmara Municipal irá se resumir a divisão entre lideranças de dois grupos rivais que disputavam por maior poder e influência. Entretanto, não haverá uma oposição ideológica sistemática que representasse antagonismos políticos de classe. Em conjunturas desfavoráveis, em que se ameaçavam rupturas mais drásticas, os fazendeiros construíam consensos entre as lideranças da política local pela manutenção da ordem. Isto pode ser visto, por exemplo, em uma notícia do Jornal A Cidade:

\section{A GREVE}

\section{A LIGA DOS PATRÕES}

No domingo à tarde foi distribuído pela cidade um boletim com o título "Liga dos Patrões", convidando-se os proprietários para uma reunião, onde se deviam tratar dos meios de terminar a parêde dos operários, que, ha cerca de dois mezes, vem perturbando o trabalho e a economia do município.

A "Associação Commercial", comprehendendo, mais calmamente, que por outros modos podia intervir para o restabelecimento do trabalho entre nós, de modo a ficarem satisfeitos patrões e operários, resolveu chamar a si a questão, e envidar todos os esforços para esse fim.

Com semelhante propósito a directoria dirigiu-se hontem aos srs. dr. Enéas da Silva, nosso director e socio honorário daquella corporação e dr. Augusto de loyolla, e lhes expoz os planos do seu nobre commettimento.

A' noite devia a Directoria da Associação ter conferenciado com os grevistas mais influentes entre os operários, os seus chefes, afim de deliberarem um acordo.

Caso, porem, o accordo razoável para ambas as partes, não seja possivel, a Associação envidará outros meios, não sendo de exthranhar que a idéia da "Liga dos Patrões" seja esposada pela Associação, mesmo que para isso se torne necessaria uma modificação dos seus estatutos. (A CIDADE: 1909: 1)

A década de 1910 seria marcada por inúmeras greves, não só de colonos das fazendas de café, mas de diversos outros segmentos de trabalhadores urbanos, como os cocheiros, que reclamavam a organização de um estacionamento para os seus carros ao redor da Praça Francisco Schmidt. Como diria o jornal, a previsão era "acabar com a balburdia, a desordem que alli se formava na 
chegada do trem." "30. Porém, a greve com manifestações e piquetes dos cocheiros pelas ruas da cidade, que intimavam os companheiros para a paralisação do trabalho, termina em desavenças pela atitude de um fura-greve, como noticía o jornal:

O facto é que o cocheiro Lazaro Fragoso, do carro n. 31, não solidario com a greve foi a estação esperar passageiros, tendo por isso exasperados os companheiros provocando-se por isso um conflicto que, graças a intervenção rapida e energica da polícia não teve consequencias serias.

Reunidos na estação intimaram áquelle cocheiro que não trabalhasse e como esse a isso se recusasse impediram que os passageiros tomassem lugar no seu carro.

Lazaro resistin e isto baston para que os paradistas atirassem de cima da boléa por sobre as rodas e o esbofeteassem.

A polícia interviu então, sendo estabelecida a ordem e tendo sido intimados a comparecer á policia todos os grevistas.

A' tarde o carro de Lazaro continuou funccionando, guardado por um praça de policia.

Ao que sabemos e como é justo e natural, a Prefeitura absolutamente não transijirá.

A policia garantirá também plenamente todos os cocheiros que quiserem trabalhar. (A CIDADE: 1911: 1-2)

Em 1912, o jornal publica os rumores sobre outra greve que estouraria nos dias 9 e 10 do mês de maio, realizada pelos leiteiros da cidade. A greve ocorreria em virtude dos últimos lançamentos do Imposto de Indústria e Profissões, sendo noticiada no jornal A Cidade num tom conservador: "como a época é de gréves, um meio ha para a desforra, pelo menos. É fazerem greve também os freguezes na occasião do pagamento do consumo mensal de leite", e ainda sobre o pagamento do imposto o jornal se posiciona, "O melhor, mais certo e criterioso épagar o imposto que é justo e equitativo, e deixar as greves, porque com gréves não se revogam leis e nem se faz adminisração’’31.

Os pedreiros da cidade também chegam a se declarar em greve contra os empreiteiros pelo aumento dos salários das jornadas de trabalho. Em virtude da grande quantidade de obras urbanas realizadas no período, o poder de barganha dessa classe não era desprezível, e o jornal $A$ Cidade publica uma nota a respeito de uma conquista dessa categoria.

\section{GREVE DOS PEDREIROS}

\section{BOLETIM - ATTITUDE PACIFICA - REUNLÃO}

Hontem os pedreiros desta cidade declararam-se em gréve geral contra os empreiteiros, reclamando o augmento de salario e quinzenal.

Os empreiteiros Lourenço Malesan, Vicente Lorenzi e Antônio Gaetano já cederam nos pedidos dos grévistas. Hoje, na séde da liga, haverá uma reunião de todos os pedreiros e serventes.

Foi distribuido hontem por uma commissão de grévistas o seguinte boletim:

"A greve geral hoje proclamada continuará até que todos os empreiteiros se decidam a reconhecer nossos direitos.

Com os empreiteiros Lourenco Malesan, Vicente Lorenzi e Antonio Gaetano, podem os companheiros trabalhar, porque esses tres empreiteiros, accederam aos nossos justos pedidos.

Amanhã, ás 7 horas da manhã, haverá reunião no séde da Liga, para a qual são convidados todos os Pedreiros e Serventes.

Viva a greve dos pedreiros! (A CIDADE: 1911: 2)

Por ocasião da quantidade de trabalhadores agrícolas associados à produção de café, nesses primeiros anos da década de 1910, seriam eles que mais conturbariam a ordem local e o andamento

30 A Cidade. Anno VII, sexta-feira, 31 de março de 1911.

31 A Cidade. Anno VII, sexta-feira, 31 de março de 1911. 


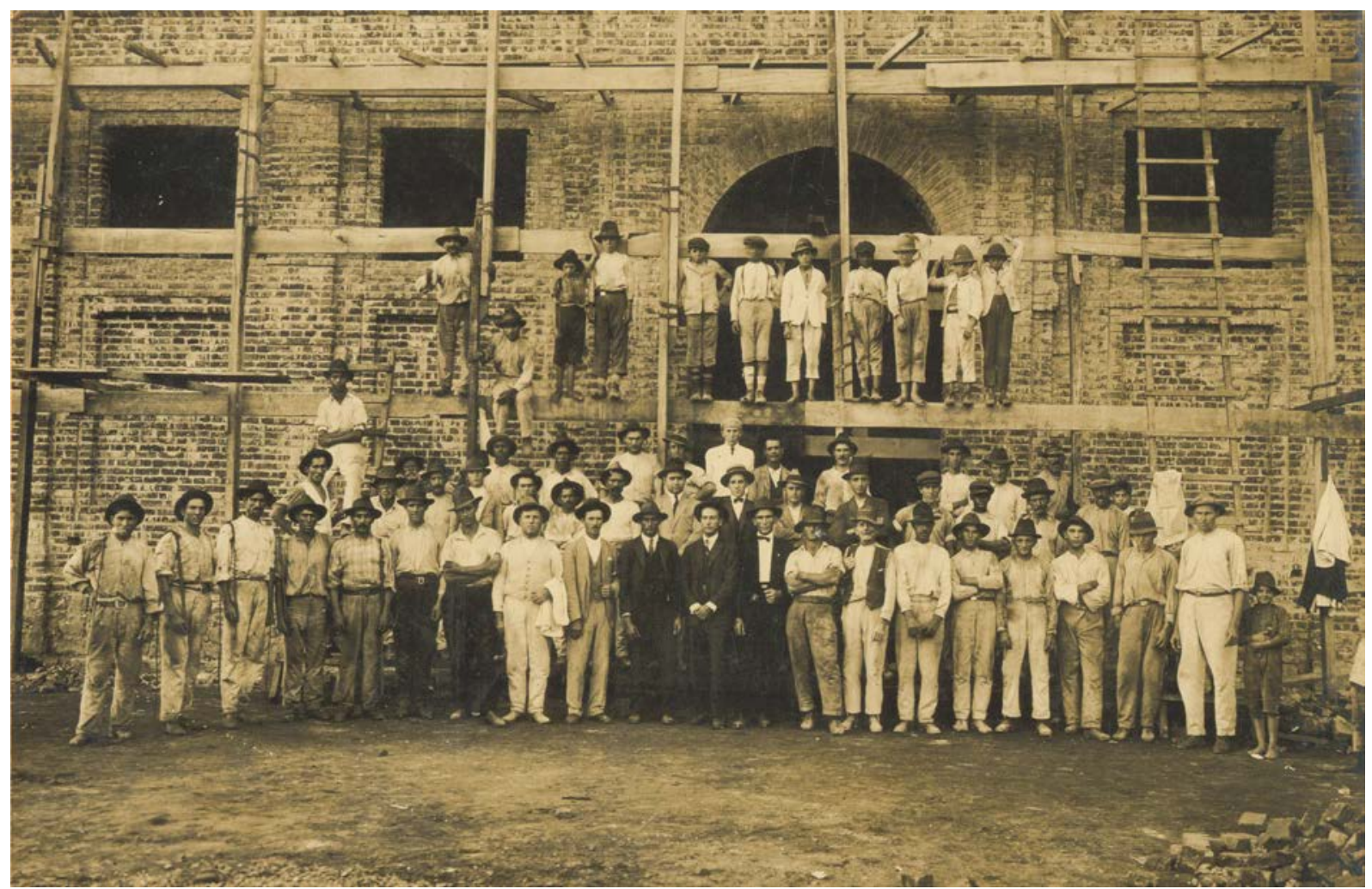

Figura 17: trabalhadores na construção de um edifício em Ribeirão Preto. Na parte superior da fotografia é possível notar uma grande quantidade de crianças. APHRP.

dos lucros dos cafeicultores. Ao longo de 1912, os colonos realizam cerca de sete greves em diferentes fazendas de café até, por fim, o coronel Francisco Schmidt convocar uma reunião entre os fazendeiros da região de Ribeirão Preto para acertar um acordo entre os produtores a respeito das retaliações aos colonos grevistas.

\section{REUNIÃO DE FAZENDEIROS}

Sobre a reunião de fazendeiros que noticiamos na nossa penultima edição, estamos informados que muitos outros municipios circunvisinhos se declararam de pleno accordo com as deliberacões tomadas na referida reunião. Assim, não contractarão colonos que, sem motivo justificado abandonem agora os patrões com quem tinham contractos firmados e em pleno vigor, nem tão pouco transigirão, fazendo concessões de qualquer natureza alem das condiçōes que se acham estabelecidas nos respectivos contractos, que serão respeitados fielmente por parte dos agricultores.

Sabemos que o cel. Schmidt tem recebido grande numero de cartas e cartões de muitos fazendeiros da zona, alem das visitas pessoaes de muitos centros, que todos lhe asseguram inteira solidariedade na justa resistencia que esta offerecendo ás descabidas exigencias dos colonos (A CIDADE: 1913: 1).

A primeira notícia sobre essa jornada de greves dos colonos publicada pelo jornal $A$ Cidade havia saído na edição de maio de 1912. A nota se referia a um motim de colonos das fazendas "Monte Alegre" e "Iracema" de propriedade do cel. Francisco Schmidt. Na greve se reuniam em torno de 120 famílias que reivindicavam o pagamento de 700 reis por alqueire de café colhido, visto que os trabalhadores tinham conseguido um aumento de 100 réis num acordo com Schmidt, que havia contratado as famílias por 500 réis o alqueire de café colhido. Os colonos das fazendas "Monte Alegre" e "Iracema" ameaçavam ainda levantar manifestações em outras fazendas, ao que o Jornal, no sentido de não dar voz aos colonos, se posiciona: "Este levante vai ser facilmente abafado, 
estamos certos, como já o foram as greves de Guatapará, S. Martinho e Dumont ${ }^{\prime \prime 32}$.

Apesar desses indícios de fissuras na ordem oligárquica republicana, os fazenderos detinham o poder hegêmonico no território em que se situava o município. Na década de 1890 se intensificara na cidade uma série de obras no espaço urbano, lugar cada vez mais expressivo para realizações de impacto simbólico e material. Apesar de em Ribeirão Preto muitos símbolos da modernidade terem chegado às sedes das fazendas, como a iluminação elétrica, o telefone e os jardins, existia uma tendência de valorização do espaço urbano, principalmente depois que a cidade é conectada à rede ferroviária com a instalação da rotunda da Cia. Mogiana. Diante desse cenário, os fazendeiros e os Intendentes Municipais irão se movimentar frente às novas demandas para a construção da cidade.

Isso será realizada, ainda que de maneira circunstancial, em meio a clivagens políticas que acompanhavam as articulações em níveis federais e estaduais, mas que orbitam no âmbito do município de Ribeirão Preto entre dois grupos rivais. Essa rivalidade surgira em meio ao forte movimento de homens de diferentes origens que se estabeleceram na região como oportunos bacharéis, mineiros criadores de gado, cafeicultores e imigrantes de diversos países. Ribeirão Preto havia chego a uma posição importante durante a Primeira República, tanto num cenário nacional quanto internacional. Assim, entre 1890 a 1920, as transformações de sua urbe seriam realizadas sob o seguinte contexto:

Liderada pelos coronéis Francisco Schmidt e Joaquim da Cunba Dinir. Junqueira - chefes politicos do município e membros de uma elite endinheirada e bandeirante, que não distinguia limites entre o público e o privado ou entre o urbano e o rural - para quem seus interesses privados eram defendidos por um corpo de doutores pelos jornais e pela Câmara Municipal, a cidade de Ribeirão Preto, ou melhor, o seu centro, foi rapidamente beneficiado com as primeiras redes de água e esgotos e de iluminação elétrica (1898-1900), calcamento e sarjetamento de ruas e a construção de edifícios como o Teatro Carlos Gomes, de 1897 (o segundo maior do país, a época) e o Palácio Rio Branco, de 1917 (sede da Câmara e Prefeitura) (PAZIANI, 2005, 180).

Esse quadro político de posições tendo a Câmara Municipal como palco das disputas, tiveram, de um lado, Joaquim da Cunha Diniz Junqueira, descendente de uma leva de portugueses que se fixaram ao sul de Minas Gerais no século XVIII, e, do outro, Francisco Schmidt, imigrante alemão que chega ao Brasil ainda criança na metade do século XIX, mas que consegue enriquecer através do comércio e da aquisição de fazendas.

Junto a Junqueira se alinhavam Augusto Ribeiro Loyola, advogado, autor do primeiro ajardinamento da Praça XV, Joaquim Macedo Bittencourt, médico, lente do Ginásio do Estado e futuro Intendente Municipal durante toda a década de 1910, e João Pedro da Veiga Miranda, politécnico, também lente do Ginásio do Estado e Intendente Municipal numa gestão antecessora a de Bittencourt. Já com Schmidt se alinhavam os advogados Fábio de Sá Barreto e Eduardo Leite Ribeiro, que irão desempenhar a função de Interventores Municipais durante a Era Vargas, quando se extingue as eleições para o executivo entre os vereadores da Câmara Municipal.

Ambos, Junqueira e Schimdt, pertenciam ao Partido Republicano Paulista, e essa oposição entre os dois acompanhava a polarização política em nível estadual e nacional. Assim, desde 1901, 
quando Campo Sales passou a liderar o grupo conhecido como "oligarquia", ao passo que Prudente de Morais articulara o grupo dos "dissidentes", surge um movimento descontente com a política federal que procurou destituir Campos Sales da presidência do mesmo modo que haviam retirado Bernardino de Campos do governo estadual.

Essa oposição adivinha de descontentamentos com a política agrícola, incapaz, segundo o grupo dos dissidentes, de conter a queda do preço do café, o que leva os políticos em torno de Prudente de Morais a organizarem os Congressos Agrícolas em Campinas e, em seguida, em Ribeirão Preto, quando cogitaram romper com o PRP e criar o Partido da Lavoura.

Nesse momento, a oposição em Ribeirão Preto elege em 1904 um vereador à Câmara Municipal, Fábio de Sá Barreto, que mais tarde seria o interventor de Getúlio no município. Sá Barreto era sobrinho do positivista Luiz Pereira Barreto, um dos entusiastas da implantação da agricultura científica na região. Porém, a situação na política local dirigida por Junqueira seguia as orientações da Comissão Central do PRP no apoio ao governo de Jorge Tibiriçá, precursor de Bernardino de Campos nas eleições de 1904 e 1908. Tal polarização se acirra em Ribeirão Preto no ano de 1909, quando a Comissão Central do PRP lança a candidatura de Rui Barbosa para presidência da República, o que desencadeia na cidade uma campanha civilista contraria à candidatura militar de Marechal Hermes Fonseca. Tal fato promove a dissidência de João Pedro da Veiga Miranda, admirador de Rui Barbosa, dos quadros dirigidos por Junqueira, que a revelia da Comissão Central apoiara a candidatura de Hermes da Fonseca.

O apoio de Junqueira a Hermes da Fonseca vinha de sua lealdade ao General Francisco Glicério, um tradicional militarista opositor do civilismo. Rui Barbosa, por sua vez, se opunha aos militares desde o governo de Floriano Peixoto, tendo sua reeleição para o Senado em 1896 provocado a ira de parlamentares da bancada militar. Após a Revolta da Armada e dos governos militares do início da Primeira República, os presidentes civis Prudente de Morais e Campos Sales, ao construir a Política dos Governadores, tinham o objetivo de abafar a influência dos militares, principalmente após a tentativa de assassinato de Prudente de Morais por nacionalistas jacobinos. O General Francisco Glicério se opunha a esse movimento dos presidentes paulistas ao apoiar Hermes da Fonseca, sobrinho do Marechal Deodoro, na eleição de $1910 .^{33}$

Em 1909, J. P. da Veiga Miranda, que desde 1908 ocupava o cargo de Intendente Municipal, tendo sido eleito na Câmara pelos partidários de Junqueira, renuncia ao seu posto de Intendente e ao seu mandato de vereador. Adeptos da campanha civilista e partidários de Schmidt na Comissão Central do PRP incumbem J. P. da Veiga Miranda de articular um novo Diretor local do Partido Republicano Paulista para escapar da hegemonia e dos desmandos de Junqueira, que nunca havia ocupado cargo eletivo, sendo sempre representado na Câmara Municipal por seus aliados ou parentes, como Manuel Maximiano Junqueira.

Em 1911, Schmidt e J. P. da Veiga Miranda são empossados como vereadores na Câmara

33 Ver BACKES, A. Fundamentos da ordem republicana: repensando o pacto de Campos Sales. Porto Alegre: UFRS, 2004. 
Municipal e recebidos como opositores pelo Intendente Municipal Joaquim Macedo Bittencourt. A situação política local se punha em desacordo com a situação estadual, e os vereadores articulados por Junqueira compunham a maioria na Câmara desde os governos estaduais de Jorge Tibiriça. Mesmo à revelia da situação estadual, o grupo de Junqueira se via bem amparado pela esfera federal em virtude de seu apoio a Hermes da Fonseca, que havia governado o país de 1910 a 1914.

Em um trecho do relatório de Intendência de Joaquim Macedo Bittencourt se vê o seguinte sobre essa situação política:

Devem ainda ser bem lembrados de todos as condiçẽes em que assumimos o governo do município em janeiro de 1911. A candidatura do Marechal Hermes e sua eleição, no anno anterior, tinham agitado a nação numa lucta memorável; a campanha civilista, guiada pelo gênio de Ruy Barbosa e pelo governo do Estado de S. Paulo, despertara tremenda reacção contra essa candidatura, que a muitos se affigurava uma tentativa de implantação do regimen militarista no Brasil; e, neste município, cujo chefe político de maior prestigio, seguindo a orientação de preclaro político republicano, já hoje fallecido, se declarara contra a politica paulista e a favor da candidatura marechalicia, a lucta assumiu taes proporções que, pela exacerbação dos ânimos e violência dos ataques, parecia ter creado incompatibilidades éódios que jamais se apagariam.

Foi numa athmosphera política assim tão carregada que, em outubro de 1910, se feriu o pleito eleitoral para constituição da Câmara, pleito renbidissimo, em que os dois partidos lançaram mão de todos os seus recursos, levando as urnas extraordinário numero de eleitores, e do qual resultou serem eleitos 7 vereadores de um e 3 do outro partido, vereadores estes que, em sua maioria, fireram até hoje parte desta illustre Câmara. (BITTENCOURT: 1920: 7-8)

Em 1910, surge em São Paulo o Partido Republicano Conservador com o intuito de abrir espaço para o hermismo no estado. Porém, em 1911, a Convenção estadual do PRP lança a candidatura de Rodrigues Alves e provoca novamente a adesão de Junqueira à situação estadual. Assim, no governo estadual de Rodrigues Alves, Junqueira retoma sua posição de aliança com a situação estadual, o que retira a força dos oposicionistas locais em torno de Schmidt. A década de 1910, marcada pela gestão do Intendente Municipal Joaquim Macedo Bittencourt, é completamente hegemonizada pela situação construída em torno de Junqueira, com quatro gestões subsequentes praticamente sem oposição. Tal contexto só começa a ser quebrado em 1916, no momento do lançamento das Ligas de Defesa Nacional pelo poeta Olavo Bilac.

Bilac era sempre convidado pelo vereador oposicionista Renato Jardim para visitar e discursar na cidade. Jardim era outro dissidente do grupo de Junqueira que mais tarde figurará ao lado de Monteiro Lobato entre os intelectuais do Partido Democrático. Todavia, este foi o período do governo estadual de Altino Arantes, político oriundo da cidade de Batatais, casado com uma das filhas de Junqueira. Embora se difundisse as ideias nacionalistas de Jardim e o seu apelo pelas visitas de Olavo Bilac com apoio na Câmara de J. P. da Veiga Miranda. Somente em 1926 a oposição ganha mais força em torno do Partido Democrático, que logo após de ter sido criado pelo Conselheiro Antonio Prado na cidade de São Paulo passa a realizar comícios no município de Ribeirão Preto para fortalecer o movimento de afiliação local.

Em 14 de julho de 1926 é criado o Partido Democrático de Ribeirão Preto com direito a apresentação de desfile e banda na praça central da cidade. A plataforma do PD nesse momento era pelo voto secreto e pela organização de partidos que estivessem fora do jogo eleitoral da Primeira 
República. Todavia, Thomas W. Walker (2000: 73) define o desempenho do Partido Democrático de Ribeirão Preto da seguinte forma:

Trabalhando dentro de um sistema basicamente não democrático, o Partido democrático local não foi exatamente um sucesso como força eleitoral. Ele e organizaçoes afins de outros municípios conseguiram eleger alguns democratas para cargos legislativos estaduais e federais. Mas na importante disputa local de 30 de outubro de 1928, foi incapaz. de obter cadeira na Câmara, recebendo apenas 14,46\% do total de votos apurados. Ainda assim, o Partido Democrático foi importante por institucionalizar a oposição ao sistema não democrático, servindo como base de treinamento para a nova elite que assumiria, após 1930, algum papel na política; e por colocar na defensiva o antigo PRP.

Nesse mesmo ano de 1926, um grupo de imigrantes italianos cria o Partido Fascista e, ao longo de 1927, o jornal A Cidade irá publicar regularmente artigos favoráveis às políticas de Mussolini. Mais tarde, os integralistas, com a fundação da AIB local, irão alugar o Teatro Carlos, já decadente ao final dos anos 30, para organizar os comícios dos "camisas verdes", além de passeatas pelas ruas da cidade com a participação, em algumas ocasiões, de Plínio Salgado. Já a classe trabalhadora do município se encontrava numa posição mais fraca na organização de partidos políticos, e com a inexistência de um Partido Comunista local chegaram a organizar algumas agremiações como o Centro Operário, em 1913, a Sociedade Operária Italiana e, ao final da década de 1920, a mais forte delas, a União Geral dos Trabalhadores.

Nesse contexto político e social da Primeira República, portanto, Saturnino de Brito irá desembarcar em 1912 para tratar da crise d'água que acometia o município de Ribeirão Preto.

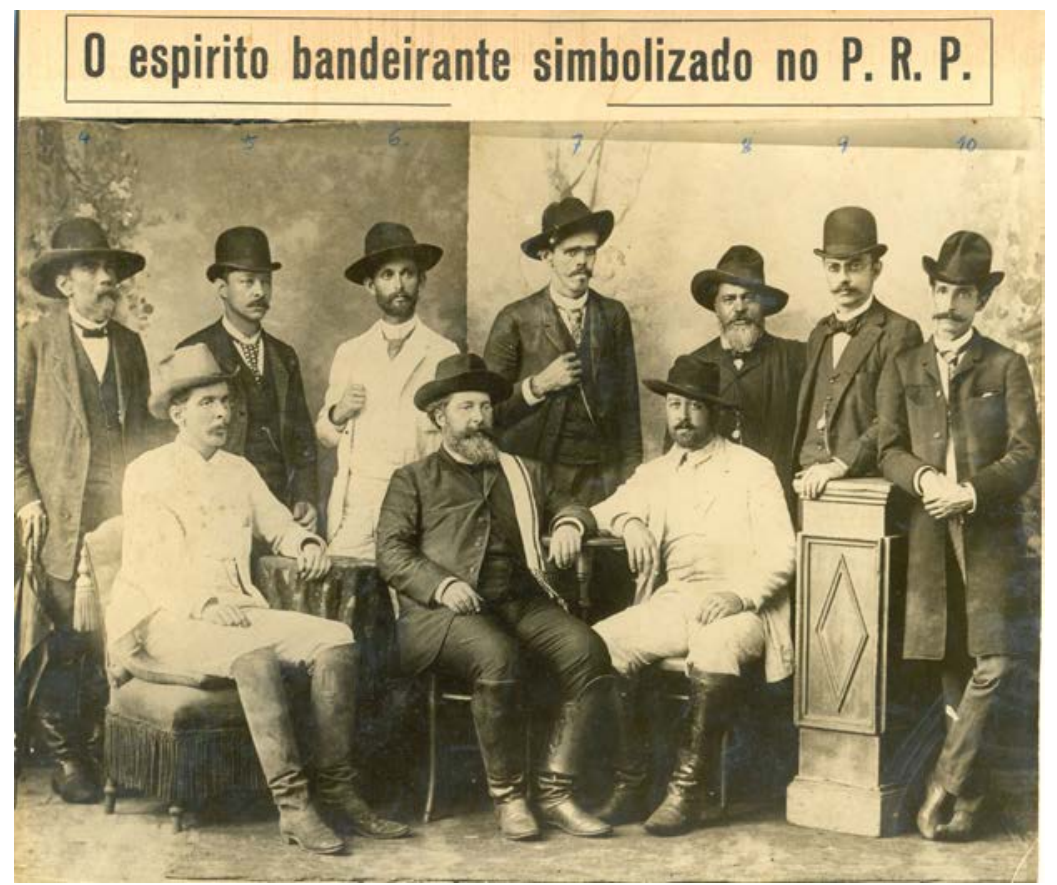

Figura 16: a incorporação da simbologia dos desbravadores do sertão de Ribeirão Preto pelo PRP local. Fonte: APHRP. 


\subsection{As polêmicas em torno dos mananciais.}

Ribeirão Preto havia agrega, como vimos, os poderes políticos necessários para angariar auxílio financeiro e, ainda restrito ao espaço do centro da cidade, inaugurar o abastecimento de água seguido da rede de esgotos ainda ao final do século XIX. Todavia, logo o serviço é arrendado à Empresa de Águas e Esgotos de Ribeirão Preto, sendo um dos investimentos da família Silva Prado na região. Entretanto, já em janeiro de 1903 se iniciam as crises de falta d'água, principalmente ao final da estação chuvosa, quando o volume dos mananciais diminui. Assim, surgem as primeiras críticas aos serviços prestados pela Empresa, que irão perdurar ao longo das primeiras décadas do século XX.

Na seção de reclamações da edição do Jornal $A$ Cidade do primeiro domingo de janeiro de 1909, surge o seguinte texto a respeito das implicações da falta d'água e das epidemias na cidade:

É certo que nestes últimos mezes tem peorado de um modo assustador o estado sanitário de nossa bela cidade, repetidos casos de febre, todas de mau carácter, estão levando aos seios das familias as mais tristes aprehensões e, a já não poucas, o luto e a desolação. Ribeirão Preto, que ainda ha pouco tempo era apontado na Europa, em conferencias que faria em diversas cidades do velho mundo, um bom amigo do Brasil, o sr. Casabona, como uma das mais saudáveis cidade do mundo, está, em assumpto de salubridade, voltando aos tempos, de que ainda perdura a triste lembrança, em que o paludismo e as celebres febres paulistas dizimavam a sua população.

Impressionado como é natural, com esta afflictiva situação e, ainda mais, com persp (sic) Cidade de 29 de Dezembro, aponta como causa do mau estado sanitário actual a falta d'água para lavagem dos esgottos e pede providências aos poderes competentes.

Ninguém ignora o quanto concorre para a insalubridade de uma cidade uma rede de esgottos sem a imprescindivel abundancia d'água, e por isso, estou de inteiro accordo com o reclamante em que providencias devem ser tomadas, energicas e promptas, para melhoramento deste serviço. (A CIDADE: 1909: 1)

Diante das aclamações públicas contra o serviço d'água prestado pela Empresa da família Prado, no mesmo ano o então prefeito municipal J. P. da Veiga Miranda, pouco antes de romper o alinhamento com a situação política capitaneado por Joaquim D. da C. Junqueira, apresenta uma moção ao gerente da Empresa de Água, Flávio de Mendonça Uchoa:

Tem chegado a esta Prefeitura constantes reclamaçoes contra a falta d'água, precisando algumas dellas uma circunstância sobre a qual desejo informações por parte dessa Empreza: queixam-se os moradores de algumas ruas da cidade, servidas pelo reservatório Schmidt, de que, após as 9 horas da noite não tem uma gotta d'água nos seus encanamentos

Comprehendo que a grande estiagem que atravessamos haja determinado o empobrecimento dos mananciais. Assim acontecendo é mister que a Empreża, como medida de previdência, procure dispor desde já de maior volume d'água, na proporção da clausula II do contracto, sem precisar valer-se do expediente de privar d'água durante a noite, alguns prédios, recurso esse de que não cogita o contracto e em extremo nocivo a bigiene. (VEIGA MIRANDA: 1909: 61)

Ficava exposto que o município atravessava uma crise de abastecimento d'água. Diante dessa situação, em 1912, é formada uma Comissão Especial pela Câmara Municipal com intuito de se avaliar a qualidade dos serviços prestados pela Empresa de Águas e Esgotos de Ribeirão Preto. 
Os membros da Comissão eram três renomados representantes da elite de ribeirãopretana - os vereadores Manuel Maximiano Junqueira, que já havia presidido a Câmara Municipal diversas vezes, Renato Jardim, antigo lente de geografia do Ginásio do Estado, J.P da Veiga Miranda, engenheiro politécnico, também lente de italiano no Ginásio do Estado, e, por fim, João A. Meira Junior, líder da Comissão e advogado da Cia. Cervejaria Paulista.

$\mathrm{Na}$ Câmara Municipal, as posições políticas acompanhavam aquelas polarizações entre Joaquim da Cunha Diniz Junqueira e Francisco Schmidt. ${ }^{34} \mathrm{Na}$ situação estavam Joaquim Macedo Bittencourt, Intendente Municipal durante toda a década de 1910, João A. Meira Junior e Manuel Maximiano Junqueira, que, ao final dos trabalhos, irão decidir pelos interesses da Empresa. Já na oposição se alinhavam os outros integrantes da Comissão Especial, João Pedro da Veiga Miranda e Renato Jardim, que haviam rompido a aliança com Junqueira, sendo os principais críticos do serviço d'água, chegando a propor a encampação do abastecimento pela municipalidade.

O parecer de J. P. da Veiga Miranda, como membro da Comissão Especial sobre a questão das águas, é iniciado se opondo à gestão do prefeito Macedo Bittencourt com o apontamento da necessidade de a municipalidade traçar um plano eficaz para resolver o problema da má qualidade das águas distribuídas em Ribeirão Preto. Tudo ao custo de não se obstruir o futuro da cidade:

Devemos declarar, antes de tudo, que entendemos ser occasião de a municipalidade traçar um plano efficaz relativamente a esse grave problema e decisivamente executá-lo. A custa, embora, dos maiores sacrificios devemos assegurar o futuro de Ribeirão Preto cujo engrandecimento e progresso se vêm entravado unicamente pelas más condições da sua água. Município rico, privilegiado pela sua posição no centro de uma zona cada vez. mais prospera, o seu largo futuro compensará tudo o que se fizer em prol da sua cidade. A Câmara Municipal não se deve impressionar com a perspectiva de algumas centenas de contos a despender, desde que desse dispêndio resulte assegurar-se o bem estar, a saúde e a vida dos nossos concidadãos (MIRANDA, 1912:1).

Desde a última década do século XIX a Câmara Municipal vinha realizando obras de combate às epidemias urbanas, como a drenagem de várzeas e a construção de canais dos rios centrais. Tais obras, bastante onerosas ao orçamento municipal, eram sempre realizadas mediante a contração de empréstimos. O próprio vereador J. P. da Veiga Miranda, quando prefeito municipal, havia realizado viagens com este fim, demonstrando na realidade que praticava uma oposição circunstancial quanto a uma "boa" condução dos negócios municipais geridos por Macedo Bittencourt:

Em duas ou três viagens feitas a Capital, entabolei negociações com diversos capitalistas abrindo concorrência pública para um empréstimo (...) [eis] nos editais publicados no Correio Paulistano: "De ordem do Sr. Dr. J.P. da Veiga Miranda, Prefeito Municipal de Ribeirão Preto, declaro que fica aberta concorrência pública para um empréstimo de 400:000\$000 (...) destinado à encampação do Mercado e a consolidação da divida futuante da municipalidade"

(MIRANDA, 1909:12).

Boa parte dessa dívida flutuante do município havia sido contraída pelo fornecimento

\footnotetext{
34 Ver CUNHA, Marcos Vinicius da. O velho estadão. Educação e poder nos anos de ouro do Ginásio Otoniel Mota. Ribeirão Preto: Palavra Mágica, 2000; WALKER, T. W.; BARBOSA, A. de S. Dos coronéis a metrópole, fios e tramas da sociedade e da política em Ribeirão Preto no século XX. Palavra Mágica: Ribeirão Preto, 2000; e PAZIANI, Rodrigo Ribeiro. Construindo a petit paris: Joaquim Macedo Bittencourt e a belle époque em Ribeirão Preto (1911-1920). FHDSS/Unesp, 2004, Franca. (tese de doutorado em história).
} 
de materiais junto ao Governo do Estado para a construção da rede de água por meio de um financiamento de 60 contos de réis. Além disso, o município havia contratado fretes realizados pelas Cia. Inglesa, Cia Paulista e Cia. Mogyana, numa ordem de mais de 400 contos de réis. J. P. da Veiga Miranda ainda absorve outro empréstimo junto ao próprio diretor da Empresa de Água, Flávio Uchoa, na ocasião do calçamento a macadame das ruas da cidade.

\section{Empréstimo de 1.000 contos}

Já foi inteiramente emitido o empréstimo de 1.000 contos autorisado em 1905 pela Câmara Municipal, para o serviço de macadamisação da cidade.

As emissões foram feitas pela forma seguinte, em letra ao portados do valor de cem mil réis, juro de 10 por cento, pago semestralmente:

- 5.000 letras entregues, conforme clausulado contrato do calcamento, ao empreiteiro Dr. Flavio Uchôa. (VEIGA MIRANDA: 1909: 16)

Assim, o que as oposições encobrem é uma função institucional que a Câmara Municipal vinha assumindo no seu endividamento pelo intuito de capitalizar empresas privadas, o que só era possível através da circulação dos mesmos agentes entre esferas públicas e privadas do município. Mais uma vez, enquanto Intendente Municipal aliado aos partidários da situação Junqueirista, J. P. da Veiga Miranda irá demonstrar suas amistosas relações com o gerente da companhia d'água numa das preocupações mais recorrentes entre os prefeitos municipais no que se refere ao abastecimento dos tanques de irrigação de praças e ruas do centro da cidade.

Jardins e Arborisação - A grande secca que atravessamos durante o anno tornou sensivel a insuficiência da água de que dispomos para irrigação dos jardins públicos. Segundo o art. $2^{\circ}$ letra D do contrato é a Empreza obrigada a fornecer 4000 litros d'água diariamente para a irrigação de cada jardim. Ora é uma quantidade verdadeiramente irrisória que sido, porém, sempre excedida graças a gentileza do gerente da Empreza.

As obras com os tanques do Jardim da Prasa Rio Branco importaram em 436\$420. O do Jardim da Praşa 13 de maio deve ser executado este ano, conforme verba já consignada no orçamento. A arborisação foi convenientemente cuidada, sendo completada a arborisação da Rua Americo Brasiliense e replantadas as das ruas Saldanba Marinho, Lafayette, Florencio de Abreu e Liberdade, além de uma ou outra muda substituida em diversos pontos. (VEIGA MIRANDA: 1909:40)

Para o prefeito municipal da década 1910, Joaquim Macedo Bittencourt, a falta d'água também irá afetar o cotidiano das pessoas que frequentavam o bairro comercial da cidade, principalmente em vista da dificuldade de se manter os serviços de irrigação de ruas e calçadas para baixar o pó, algo essencial ao projeto de modernização do centro de Ribeirão Preto.

IRRIGAÇÃO DAS RUAS - O pó é o thema obrigatório das acusaçôes que se fazem ás administrações municipais de Ribeirão Preto e, durante muito tempo ainda, estas hão de sofrê-las, porque diversos factores concorrem para tornar difficílima, senão impossivel, a solução do problema da sua extinção.

A natureza do calçamento, as muitas ruas ainda não calçadas e a grande extensão de terrenos occupados por quintaes, de onde o vento levanta densas nuvens de pó nas ruas calcadas e, principalmente, no bairro commercial, onde causa tão grandes prejuízos aos commerciantes; mas, mesmo para isso, havia a difficuldade de falta d'água, pois que os reservatórios de abastecimento público não supportavam as enormes sangrias que exige o serviço de irrigação.

Para remover este obstáculo, fez-se uma canalização especial captando-se a água do córrego do Retiro e elevando-se, por meio da bomba electrica, até a rua Ruy Barbosa, de onde é distribuida para irrigação das ruas e dos jardins. Assim, se poude fazer diariamente este serviço, que só era interrompido 
quando se dava qualquer desarranjo na bomba. (BITTENCOURT: 1920: 44)

Em 1912, já como integrante da Comissão, o problema para o vereador, agora na oposição, iria um pouco além. J. P. da Veiga Miranda apresenta o abastecimento d'água de Ribeirão Preto realizado com 2.900.000 litros de "água de fonte"; e 2.400.000 de "água dos rios" - rio Pardo e ribeirão Preto, sendo estas últimas o motivo de reclamações da população. Contrariando a Empresa de Água e Esgoto e a Prefeitura Municipal, o vereador alega que, mesmo com o maior otimismo, as águas distribuídas naquele ano eram medíocres, com uma quantidade excessiva de matéria orgânica e produtos em suspensão.

A Empresa, que havia distribuído água suja à população, alegava que em outras épocas do ano a quantidade de tais substâncias diminuía, mas que no tempo das chuvas as "águas de rio" eram um grande lamaçal, sendo difícil abastecer a cidade somente com as águas cristalinas das cabeceiras dos mananciais. A Empresa se comprometia a corrigir este defeito com a construção de filtros, além de um tratamento pelo alumen e a cal, porém pedia em troca uma concessão para que se reduzisse o volume de água para a cota de 100 litros por habitante, o que equivalia à cota de mil litros de água para cada casa.

J. P. da Veiga Miranda, entretanto, argumenta que a proposta não devia ser aceita em virtude de se almejar para o município uma cota semelhante à de Berlim (113 litros), Londres (149 litros) e Paris, considerada um modelo para o vereador com o fornecimento de 272 litros de água por habitante. Para o vereador, aceitar a proposta da Empresa era equiparar-se ao abastecimento razoável de cidades como Bruxellas (71 litros por habitantes), Bremem (85 litros), Aix-la-Chapelle (76 litros) e Konigsberg (65 litros).

O ousado vereador dizia da tribuna da Câmara que a redução da cota por habitante provocaria o recrudescimento do clamor popular e agravaria ainda mais as condições de salubridade dessa população:

Realmente, bem sabemos que em muitas cidades não chega a tanto o volume por cabeça: Bruxellas tem 71 litros por habitante; Bremen tem 85; Aix-la-Chapelle 76 e Kinigsberg 65. Mas Berlin tem 113; Hamburgo 189, Londres 149 e Paris 272. Logo não é uma base, é um minimo, o volume de 100 litros por cabeça.

Redu₹ir, porém, a esse mínimo o serviço em Ribeirão Preto será provocar o recrudescimento do clamor popular e agravar as más condiçoes de salubridade a que já fomos conduzidos (VEIGA MIRANDA: 1912: 3).

Saturnino de Brito, que tinha adquirido fama como engenheiro sanitarista, é convidado pela Prefeitura Municipal da "Capital d'Oeste” para realizar o seu parecer. Em 1912, Brito já havia realizados trabalhos sobre o abastecimento d'água de cidades como Campinas (1896), São Paulo (1905) e Recife (1911). Logo, sobre a questão do volume d'água distribuído, ele aponta que a cidade de Ribeirão Preto possuía três mil casas em seu núcleo urbano com uma população de 18 mil habitantes, e que a Empresa distribuía água em 2.400 casas com uma pena d'água de 1.500 litros diários para 2.140 casas e outra de dois mil litros para 260 casas. Nota-se, portanto, um desequilíbrio entre o volume das duas penas, demonstrando um abastecimento desigual dentro do 


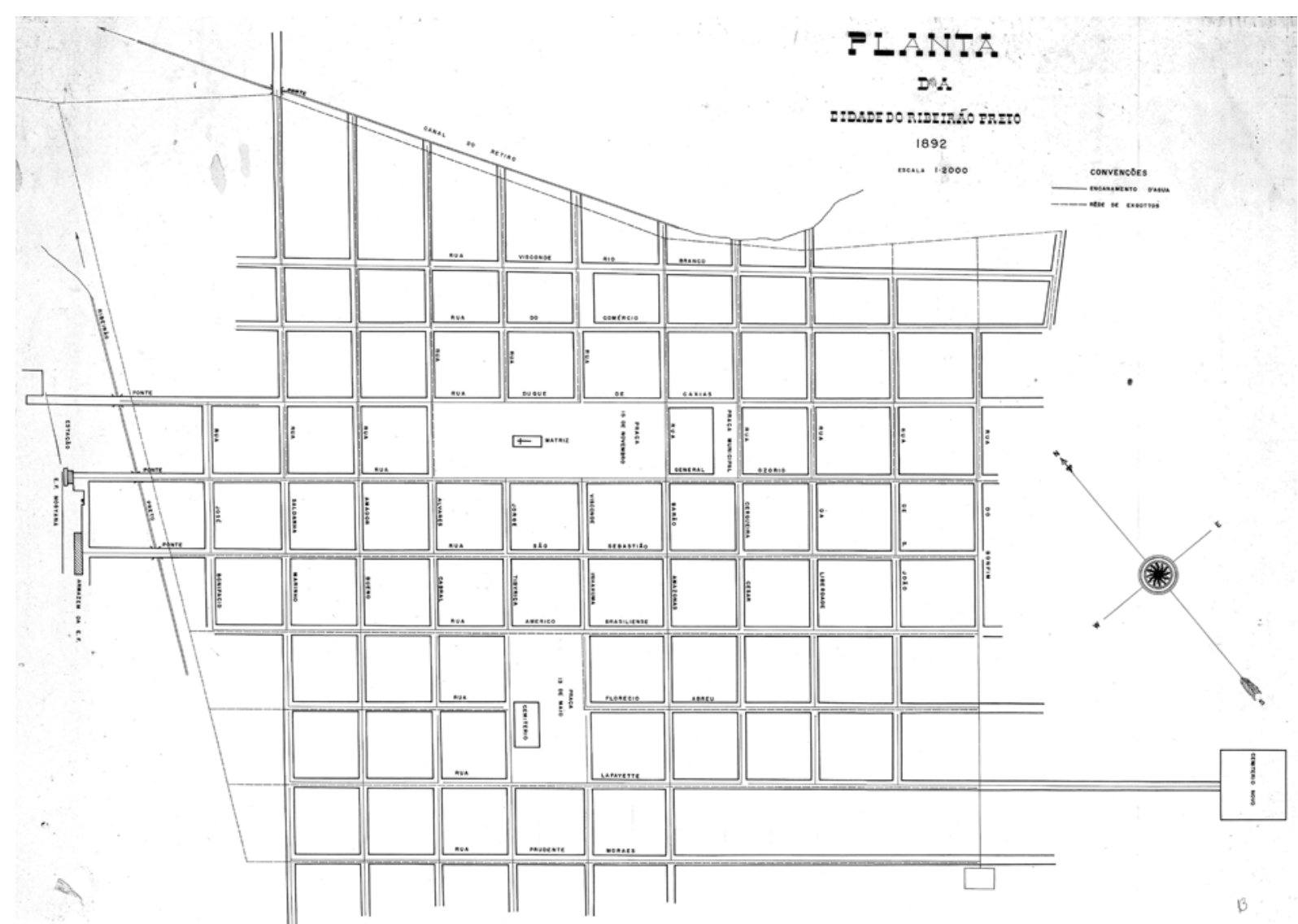

Mapa 4: planta da rede com as tubulações saindo do reservatório Schmidt na extremidade da Rua Prudente de Moraes ao sul na região mais alta do centro. Pela gravidade, a tubulação de esgoto realizava a coleta de águas servidas e as escoava na vertente do rio Preto ao norte da cidade. Desse modo, a rede irá contribuir para a consolidação da formação socioespacial da cidade - fabricas e operários a jusante do rio Preto; loteamentos-jardins a montante do mesmo rio numa área mais arejada. Nos relatórios de Saturnino de Brito sobre o abastecimento d'água é recorrente o conhecimento de que as águas disponíveis pela adução por gravidade são mais baratas em relação às águas caras distribuídas por elevação mecânica. Em qualquer cidade, portanto, a construção de urbanidade em terrenos mais altos exige maiores dispêndios de recursos públicos. Fonte: APHRP.

núcleo urbano da cidade de Ribeirão Preto.

O engenheiro faz uma previsão de abastecimento para 20 mil habitantes, avaliando ser necessário, para todos os serviços, público e privado, $4 \mathrm{mil} \mathrm{m}^{3}$ diários de água, com 200 litros por habitante, deixando margem para a previsão de desperdícios. No seu estudo A Água em São Paulo, escrito para o Governo do Estado, em 1905, Brito inicia esclarecendo o seguinte a respeito do volume d’água a ser distribuído:

Comecemos lembrando que não se deve confundir a quota básica da distribuição à cidade com a quota essencial a cada individuo ou a cada casa: se bem que aquela seja referida ao "babitante" não se conclui que a este caiba o consumo próprio que lhe é atribuido para as suas necessidades diretas e para as indiretas (a lavagem de esgotos, a irrigação e as fontes dos jardins públicos, os serviços industriais, as perdas irremediáveis, e os usos extraordinários, públicos ou particulares). (BRITO: 1944: 25)

Ou seja, em seus projetos de abastecimento, o engenheiro distinguia uma a) quota essencial para cada domicilio; e outra b) quota básica para o serviço da cidade, determinando um caudal de uma "pena" d'água de 1.200 litros diários, o que poderia fornecer entre 100 a 300 litros por habitante, dependendo do grau de adensamento dos moradores por casa. O seu coeficiente padrão era: 


$$
\begin{gathered}
Q=\text { pena d'água }=1.200 \text { litros }=172 \text { litros por habitante. } \\
N^{o} \text { de habitantes }=7
\end{gathered}
$$

Todavia, esta era a cota que Brito estabelecia para o consumo humano, sem considerar os outros usos relativos ao funcionamento de qualquer cidade, como a irrigação de jardins, lavagens de ruas e esgotos e o consumo industrial, sendo o mais volumoso.

Nem todos pensam assim, e, atordoados pelo entusiasmo da gritaria coletiva a exigir o "precioso líquido", os engenheiros das águas vão somando aos produtos das penas pelo numero de prédios os volumes arbitrados para os outros misteres. Não queremos concluir que sejam suficientes os 172 litros para a satisfaça de todos os serviços em uma cidade como o Rio de Janeiro atual, embora possamos afirmar, com as melhores autoridades, que a mesma quota básica - correspondente à pena, excessiva para atender a todas as necessidades de uma cidade como Campos, bastando 100 litros, ou 130 no máximo, convenientemente distribuidos (BRITO: 1944: 26)

Ribeirão Peto não possuía uma densidade populacional equivalente ao do Rio de Janeiro que, segundo Sevcenko (1998), contabilizva quase um milhão de habitantes no começo do século XX, com a grande maioria de negros remanescentes da escravidão ou de libertos que para lá haviam migrado após a abolição. Ligada às atividades portuárias, essa população se concentrava nos cortiços que se formaram nos antigos casarões próximos ao Morro da Providência e ao Morro do Livramento. A alta densidade das habitações aliada à pobreza e a outras formas de convívio dessa população, era o alvo das autoridades municipais que representavam tais cortiços como uma ameaça à ordem, à segurança e à moralidade públicas.

A capital, na ocasião, se tornara o principal porto de exportação e importação do país. Além disso, era objeto do desejo de fazer dela a vitrine da República recém-proclamada. Entretanto, o Rio de Janeiro, muito em virtude de um precário abastecimento d'água, era acometido por diversas epidemias de malária, tuberculose, além da varíola e da febre amarela que grassavam todos os verões. Dessa maneira, a convivência adensada tornou-se uma questão primordial de saúde pública, e dispersar aquela população entra na pauta dos políticos da capital federal com os planos de reformas urbanas - a modernização do porto; o saneamento da cidade e a reurbanização.

Sobre a polêmica densidade do Rio de Janeiro, Brito declara:

No Rio de Janeiro foi demitido um ilustre diretor da Estatística pelo fato de ter apresentado um resultado que não excedia 500.000 babitantes. Não lhe valeram todos os argumentos relativos à proporcionalidade de nascimentos, óbitos, casamentos, etc. (...) reconhecendo assim, quão perigoso é procurar a verdade em semelhante assunto, não hesitei, entretanto, provar o relatório ao Sr. Ministro da Indústria, pelos dados relativos ao serviço de águas e esgotos, que a populaşão da Capital da República não poderia exceder então 500.000. Ulteriormente o ilustre Sr. Hilario de Gouveia, ocupando posição oficial como nosso representante em um Congresso estrangeiro, provocou a mesma questão, mostrando que se a população fosse de 700.000 a 1.000.000 de babitantes, conforme por "sentimento" arbitram alguns "estatísticos", a cidade não precisaria de serviço algum saneador, porquanto, pelos quadros demográficos, seria uma das cidades mais salubres do mundo! (BRITO: 1944: 31)

Diante da ironia do ilustre corresponde brasileiro, o fato é que a densidade da Capital Federal se tornara uma questão de Estado, e não era conveniente apresentar os dados populacionais reais do Rio de Janeiro durante os conturbados anos iniciais da transformação da cidade. Frente às revoltas contra as visitações domésticas, a vacina obrigatória, os desmontes de habitações coletivas e o afastamento das classes populares do centro do Rio de Janeiro, os técnicos manipulavam os 
dados de acordo com as suas projeções futuras da cidade.

Para realizar os cálculos das cotas de distribuição por domicilio dos seus relatórios, Brito estabelece a base de 7 habitantes por prédio, argumentado que parecia ser esse número, segundo suas ideias aproximadas, a média da densidade das cidades brasileiras. Todavia, ele alega o seguinte sobre a situação dos edifícios da cidade de São Paulo:

Temos 22. 026 de um só pavimento e 1.923 de dois ou mais; embora se queira figurar a dormida em "beliches" ou "prateleiras" para certos albergues italianos, não é licito pretender que a densidade exceda a que se observa nas cidades europeias (Manchester, com 106. 000 casas, não representa mais do que 6 habitantes porprédios (BRITO: 1944: 32)

Brito condenava as diversas habitações coletivas no entorno do centro de São Paulo, construídas na direção das várzeas dos rios Tamanduateí e Tietê, cada vez mais ao leste da cidade em bairros, como o Bexiga, o Brás e a Mooca, que passam a abrigar os trabalhadores das fábricas de tecidos, gás etc. Tomando por base as cidades norte-americanas, com exceção de Nova Iorque, ele apresenta o quadro de densidades que deveria ser considerado como referência a se alcançar nas cidades brasileiras, o que fortalecia o argumento do desmonte de moradias coletivas em suas regiões centrais.

\begin{tabular}{|c|c|c|c|}
\hline CIDADES NORTE-AMERICANAS & POPULAÇÃOO & $\begin{array}{c}\text { PESSOAS } \\
\text { POR } \\
\text { FAMILIA }\end{array}$ & $\begin{array}{c}\text { PESSOAS } \\
\text { POR } \\
\text { HABITAÇÃO }\end{array}$ \\
\hline New York...... & 1.206 .299 & 4.96 & 16.37 \\
\hline New Orleans.... & 216.090 & 4.77 & 5.95 \\
\hline Providencie........ & 104.857 & 4.52 & 7.41 \\
\hline Kansas City......... & 55.785 & 5.97 & 6.48 \\
\hline Nashville........... & 43.350 & 5.10 & 6.13 \\
\hline Denver............ & 35.629 & 5.99 & 6.75 \\
\hline Harrisburg ............. & 30.762 & 4.78 & 5.16 \\
\hline Erie .................. & 27.737 & 5.24 & 5.66 \\
\hline Des Moines.............. & 22.408 & 5.14 & 5.37 \\
\hline Sacramento.......... & 21.420 & 4.51 & 5.07 \\
\hline Springfield............. & 19.743 & 5.04 & 5.60 \\
\hline
\end{tabular}

Figura 18: Tabela de densidade das cidades norte-americanas. Fonte: BRITO: 1944: 32.

Ribeirão Preto, então com 60 mil habitantes, incluindo a população das fazendas, possuía a média de 9 habitantes por casa no seu núcleo urbano. Assim, não se chegava a uma situação tão convulsiva como a do Rio de Janeiro ou à densidade demográfica de Nova Iorque. Entretanto, o município também havia efetivado o seu ciclo de reformas urbanas no quadrilátero central da cidade, com a remoção de habitações coletivas e as restrições estabelecidas para edificações pelos Códigos de Posturas. Isso fez com que Ribeirão Preto, após esse período de transformações, possuísse no perímetro da rede de abastecimento d'água um adensamento semelhante ao da cidade de Campos, 
no estado do Rio de Janeiro, fazendo com que Suturnino de Brito estabelecesse a mesma cota de abastecimento por casa para a cidade.

Para a cidade de São Paulo, que possuía na ocasião do estudo de Brito uma população em torno de 350.000 habitantes, ocupando por volta de 26.000 prédios, apesar de uma taxa de crescimento de três mil casas anuais, cinco vezes superior ao Rio de Janeiro, se emparelhando às cidades de madeiras dos yankees, como Chicago, com mais de 10 casas por dia. No caso paulistano feitas de pedra, tijolo e argamassa, Brito estabelecia o seguinte:

Claro fica que para S. Paulo a base será tomada como de serviço de uma grande cidade.

O Sr. Dr. Francisco Bicalho, com a autoridade que todos the reconhecem, estabelece as seguintes quotas parcelares para o uso domiciliário, a par das quais colocamos outras de distribuição mais liberal: Litros

Para bebida

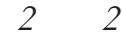

Para o preparo de alimentos ............................................................... 6

Para a lavagem dos utensilios ............................................................ 29

Para ablucôes no dia ........................................................................ 5

Para banbo de chuva on quente ………………………………......... $10 \quad 30$

Para lavagem de roupas ………………......................................... $10 \quad 15$

Para limpeza do water closet .......................................................... 99

Para eventuais e perdas ................................................................... 6

Total, litros

O engenheiro definia, que para a distribuição doméstica da cidade de São Paulo, 60 litros seria suficiente, sendo a de 100 litros liberalmente concedida. Para uma casa, portanto, a quota de 420 litros por dia daria conta de uma distribuição suficiente e econômica, sendo a quota de 700 litros no caso de uma distribuição liberal. Porém, para ele seria forçoso reconhecer que a base antiga de 1.200 litros seria exagerada em virtude de não existir a garantia da distribuição deste volume diário em qualquer cidade que adotasse a regulamentação pelas "penas d'água". Ou seja, as diárias reclamações sobre o abastecimento em diversas cidades eram uma evidência de vazamentos ou desperdícios, de modo que, para o engenheiro, seria raro o caso da absoluta falta d'água. $\mathrm{O}$ mal geralmente era reconhecido na má distribuição.

Além dessa distribuição doméstica, para compor a cota básica de distribuição d'água para todos os serviços que afetam uma cidade, Brito estabelece o padrão de 220 litros diários por habitante, e ressalva, no caso de São Paulo, que não se deveria exagerar na cota de distribuição em razão do seu crescimento industrial, pois a tomada de água direta do rio Tietê seria uma opção econômica e essencial. Algo semelhante ao que ele propõe para Ribeirão Preto no caso das fábricas tomarem água direta dos rios de seu perímetro central, o que acontecerá, principalmente, no curso do ribeirão Preto pela zona norte do município.

Dessa maneira, se entrevê nos sistemas de abastecimento d'água uma leitura da divisão sócio-espacial das cidades em que são implantados. No caso de São Paulo, sendo algo que se reproduz em Ribeirão Preto, se vê a seguinte leitura topográfica e social de Satunino de Brito ao descriminar as zonas de distribuição: 
a) Zona Altissima: - 200 litros por habitante e por dia; nestas zonas predominam as casas nobres; se bem que o consumo para irrigação de jardins particulares seja maior, é de notar que os serviços públicos e industriais não existem em proporção a realizarem consumo apreciável; a água virá da caixa da Avenida, por elevação mecânica, e o consumo imoderado não pode ser admitido.

b) Zona Alta: - 250 litros por habitante e por dia; está quase nas mesmas condições da primeira (...) Presentemente a estatistica deficiente que nos foi possivel obter atribui a estas duas zonas um serviço a cerca de 4.600 casas ou seja a 30.000 habitantes: a caixa fornece a 2.749 prédios e a linha de 12" a 1.877. Assim, na melhor hipótese, - quando a água seja abundante e supondo que as sangrias existentes hajam desaparecido, - teremos por habitante e por dia cerca de 250 litros.

c) Zona Média: - 300 litros diários por habitantes; abrange a parte da cidade de maior vida social e onde maiores são os serviços públicos; para aí aflui a população durante as horas diurnas. Atualmente não abastece mais de 15.100 casas ou a 105.700 habitantes; temos, portanto, apenas a quota de 236 litros, inferior à base proposta.

d) Zona Baixa: - 200 litros diários por habitante; esta é a zona marginal aos cursos d'água (o Tietê e o Tamanduateí); nela habitam os proletários, principalmente italianos, e de preferência a indústria ai se estabelece, podendo, portanto, suprir-se d'água nos cursos próximos ou no lençol d'água da ampla várzea. . Será a zona de maior amplitude, a mais populosa, por onde a cidade se desenvolverá sem limites. Nesse porvir, quando o consumo seja tão abundante que se torne por demais oneroso a distribuição d'água pura ou purificada, poderá o governo favorecer a iniciativa particular de tomada das águas brutas dos cursos para os serviços inferiores (lavagem de esgotos, industrias, irrigaçôes, etc), duplicando ai o sistema de distribuição, um para cada serviço. (BRITO: 1944: 29)

Os estudos para o abastecimento d'água de cada uma das zonas da cidade de São Paulo permite a identificação de sua distribuição sócio-espacial. As elevações de altitude dos bairros e regiões distinguem a tônica da ocupação urbana. As zonas Altas e Altíssimas, demarcadas ao longo da Avenida Paulista e do bairro Higienópolis, já eram ocupadas em 1905 por moradias de classes mais abastadas, compondo uma faixa limítrofe aos terrenos que futuramente foram adquiridos pela Cia. City, onde serão implantados os bairros-jardins. Na zona Média vemos o antigo centro da colina entre os vales do Tamanduateí e Anhangabaú, onde a cidade foi fundada. Já nas zonas baixas ao longo das várzeas do rio Tietê, no sentido leste, vão surgindo os bairros populares do Pari, Belenzinho e Mooca, para os quais Brito sugere a capitação de água direta das várzeas.

Segundo o vereador J. P. da Veiga Miranda, o modelo de abastecimento d'água que deveria ser seguido em Ribeirão Preto, era o seguinte:

O que caracteriza o serviço de águas de Paris e coloca a grande capital numa situação favorável sob todos os pontos de vista é a divisão daquele serviço em duas partes inteiramente distinctas e separadas, o serviço público e o serviço particular. Foi o eng. Beldrand quem elaborou esse projecto e se esforçou por vê-lo realisado.

O serviço público compreende as vias públicas, os jardins, as indústrias, as cavalarias, a irrigação, lavagens de pateos e toda a rede de esgotos. Nas suas canalizações especiais correm as águas de Ourcq, do Sena, do Marne e dos poços artesianos, águas que foram afastadas do consumo bumano como nocivas a saúde.

O serviço particular é alimentado pelas águas de fonte, de quatro grandes aduçöes trazidas por aquedutos fechados a reservatórios cobertos, de sorte que não há possibilidade de contaminação em marcha do ponto de onde emergem até a torneira do consumidor.

Dos 275.210 .800 metros cúbicos de água recebidos pelos parisienses em 1910 do relatório do Conselho Municipal de Paris, 66 milhões são de água de fonte e 215 milhões de água de rio. Isso dá a média de 275 litros por habitante por dia, sendo 92 de água potável e 180 de água de serviço publico (MIRANDA, 1912:5)

O vereador acreditava ser possível a construção do sistema parisiense, sendo, todavia, 


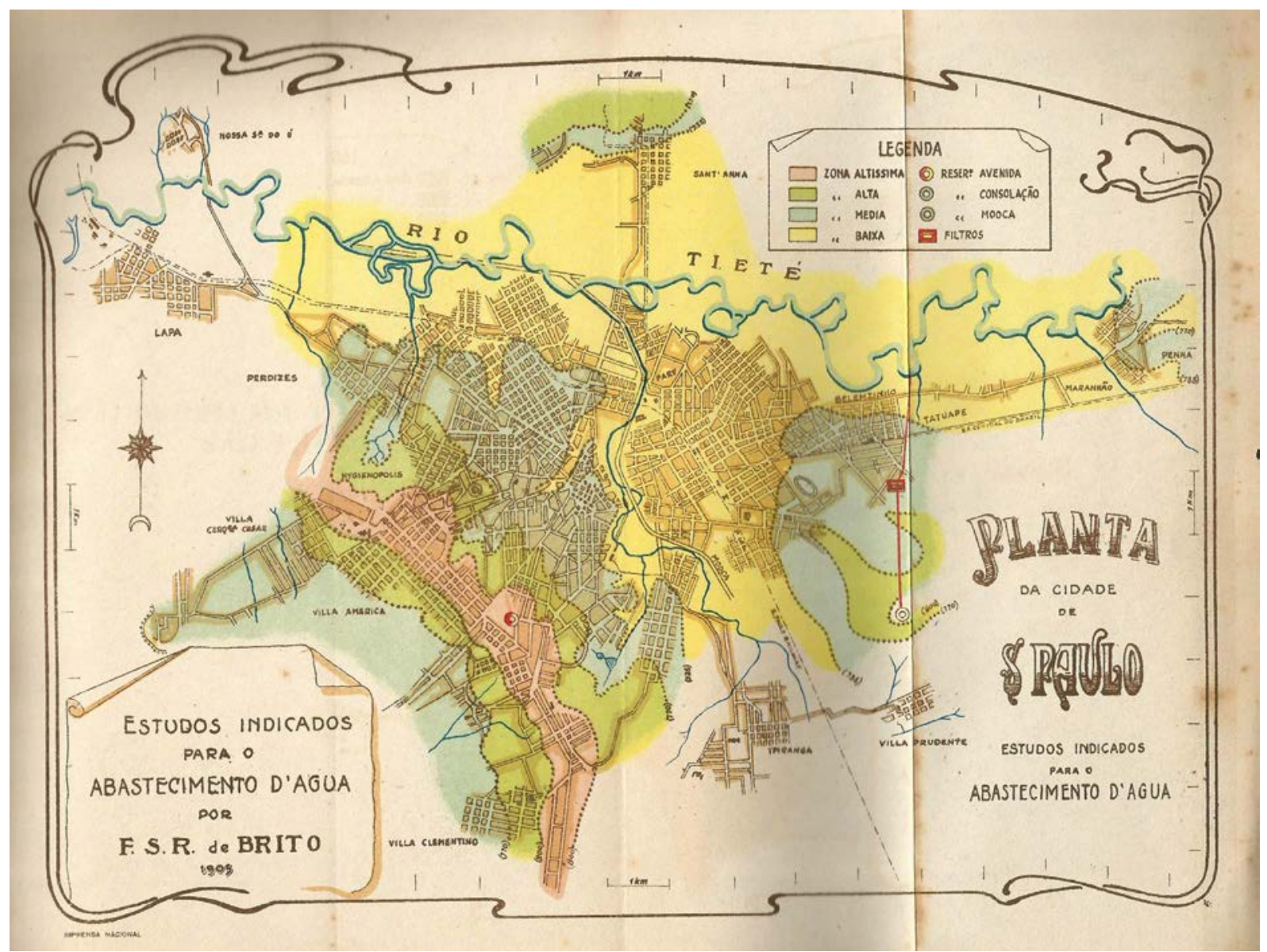

Mapa 5: A partir dos estudos indicados para o abastecimento d’água de Saturnino de Brito é possível identificar a distribuição sócioespacial da cidade de São Paulo divida pelas elevações de altitude de cada região. Fonte: BRITO: 1944: 91.

imprescindível a utilização das águas de rios para o serviço público de irrigação de jardins e lavagem de ruas, e das águas de fontes para a distribuição doméstica. Diante da impossibilidade da adoção do modelo de Paris pela Empresa de Água de Ribeirão Preto, o vereador sugeria a recisão do contrato seguida da encampação da Companhia particular pela municipalidade:

Ora, se nos virmos deante da grave situação determinada pela absoluta impotabilidade da água do Rio Pardo recorrer ao systhema de Paris?

As despesas serão grandes naturalmente. Diante de tal argumento, porém, não se deve deter a ação da municipalidade. Se há alguma causa que justifique o arrojo dos grandes dispêndios é a saúde publica.

Ademais a duplicação do servico não precisaria ser feita de uma só vez. Proceder-se-ia gradativamente, de acordo com augmento da cidade. Dos 2.900 .000 litros que provém dos mananciais de fonte se destacariam, por exemplo, 900.000 para certa parte da cidade. Nessa parte se duplicaria o serviço, abduzindo água de rio para o serviço de exgottos etc, gênero de "serviço público" de Paris. Os dois milhöes restantes serviriam ao resto da cidade pelo systhema vigente. (...)

Caso a Câmara não possa chegar a acordo com a Empresa para execução desse serviço, entendemos que se deverá ir até a encampação ou, se for o caso, a rescisão do contrato (MIRANDA, 1912:7).

Flavio de Mendonça Uchoa, gerente da Empresa de Águas e Esgoto, respondendo às críticas do vereador, alegava que quando o abastecimento d'água era mantido pela Câmara Municipal, até 1903, também havia se chegado a uma situação aflitiva na redução do abastecimento, tendo sido 
orçadas, naquela ocasião, em 728 contos de réis as obras necessárias para aumentá-lo. A Câmara, entretanto, como não suportaria tão elevada despesa, havia decidido por unanimidade acerca do arrendamento do serviço, exigindo nos editais de concorrência a entrada de 300 contos de réis, capital que somente a Empresa apresentou para arrematar o contrato de arrendamento.

A Empresa, segundo o seu diretor, havia concluído as obras determinadas, além de haver aumentado o volume de água distribuída diariamente, passando-se cinco anos sem anormalidade nas relações entre público, Empresa e Câmara. Porém, em fins de 1908, temendo a seca acentuada, a Empresa submeteu a água do ribeirão Preto a experiências a fim de se averiguar a sua potabilidade e realizar o abastecimento da cidade com essa água. Contudo, em vésperas de se inaugurar as instalações que filtrariam 2 milhões de litros d'águas do ribeirão Preto, uma mudança de orientação da Câmara exigiu o abandono do ribeirão, possivelmente em virtude da já acentuada ocupação urbana de sua margens. O município passa a exigir da Empresa a realização da captação das águas do rio Pardo.

Após atrasos em função de processos de isenção de impostos na alfândega referente ao material adquirido, a Empresa constrói os filtros lentos de areia para a purificação das águas do rio Pardo. Mesmo com o engenheiro Arthur Motta, diretor da Repartição de Água e Esgotos da Capital, tendo alegado a necessidade de ampliação dos filtros d'água, pois os filtros lentos não seriam suficientes para realizar a clarificação da água a ser distribuída pela Empresa, a Companhia passou a utilizar as águas do rio Pardo para completar o volume dos reservatórios da cidade sem ampliar os filtros de purificação em virtude de ser algo excessivo ao seu orçamento.

Saturnino de Brito, numa carta ao prefeito de Campinas por ocasião de uma visita à cidade para qual ele havia estabelecido recomendações para os serviços da Companhia Campineira de Águas e Esgotos, na qualidade de Chefe do $2^{\circ}$ Distrito da antiga Comissão de Saneamento do Estado, escreve o seguinte:

Muitos acharão insuficiente a quota de 500 litros e não lhes faltarão argumentos. Entretanto, observemos que uma casa de baixo valor locativo é geralmente pequena e não deve comportar mais de 5 babitante, para que não resulte inconveniente, no ponto de vista higiênico, de acordo, aliás, com as prescrições dos regulamentos sanitários em vigor; teremos, então a quota liberal de 100 litros por habitante, para o pobre. Mesmo que, contra o regulamento sanitário, um casebre seja babitado por 7 pessoas, teremos 71 litros por dia e por habitante, exclusivamente para os usos domésticos. Ora, ninguém dirá que isto seja insuficiente.

Com efeito, se para uma casa rica ou burguesa forem bastantes, ao conforto e higiene, 100 litros por pessoa, bastarão ao pobre cerca de 60 litros. Porque o consumo é maior na casa em que se tome, para cada banho, um volume superior ao suficiente; o numero de utensilios de cozinha e copa, a lavar diariamente, é muito maior, principalmente quando se faça "a francesa" o serviço de mesa; etc. etc. Ora, o que é preciso na família brasileira pobre ou rica, é que a água chegue para os banhos (antigamente estes eram tomados em bacias, e as familias não eram menos asseadas que hoje); é que a louca seja toda bem lavada; - o asseio não depende de encher banheiros e do número de pratos servidos em cada refeição.

Assim sendo, me parece justo dar ao pobre o volume bastante e a um preço de unidade menor. Atendendo ao maior consumo nas casas maiores, sejam aumentadas as respectivas quotas e aumentando sejam também o preço de unidade, para uma justa compensação nos serviços prestados a pobres e ricos (BRITO: 1944: 124) 
Em Ribeirão Preto, segundo Brito, a Empresa de Água possuía $2.500 \mathrm{~m}^{3}$ de água de fonte na estiagem, faltando-lhe apenas 1.500 litros para suprir a previsão da demanda de $4 \mathrm{mil} \mathrm{m}^{3}$ para atender o serviço com uma previsão do desenvolvimento futuro da cidade. Como a rede ainda se restringia apenas às casas, palacetes e sobrados de seu perímetro central, Brito estabelece um total de 6 mil $\mathrm{m}^{3}$ para sobrar água, tanto para a ampliação da distribuição para os bairros periféricos, como a Vila Tibério, o Barracão e o Campos Elíseos, quanto para se aumentar a cota de volume por habitante. Desse modo, faltaria tomar $3.500 \mathrm{~m}^{3}$ do rio Pardo, que possuía grande caudal e disponibilidade para somar aos outros mananciais durante a estiagem, o que recai mais uma vez na necessidade dos melhoramentos dos filtros pela Empresa de Água.

Em seu Relatório sobre o Abastecimento d'água em Ribeirão Preto, Brito critica a Empresa por ter distribuído águas de forte coloração para completar o volume deficiente de seus antigos mananciais, e relata o que vem propagando há anos quanto à exploração dos serviços de águas urbanas, ou seja, a difícil e delicada tarefa dos poderes públicos conciliarem os interesses sanitários com os interesses financeiros das empresas que exploram os serviços de saneamento. Em todos os países do mundo, as Empresas, segundo Brito, não poderiam bem servir sem a obtenção dos capitais empregados com a correspondente remuneração, sejam bem ou mal administrados:

Neste assumpto se torna difficil e delicadíssimo a acção dos poderes públicos das cidades para conciliarem os interesses sanitários e os das emprezas que exploram os serviços, as quaes praticamente, em todos os paizes do mundo, não poderão bem servir se não obtiverem para os capitais empregados a correspondente remuneração, sejam bem ou mal administradas. Só o poder público, colhendo vantagens indiretas dos beneficios prestados, reavendo verbas aonde perde em outras, é praticamente capaz de um sacrificio monetário para fazer o necessário ao saneamento das cidades. Não convém, nesta ordem do serviço, dividir as responsabilidades para acudir convenientemente as necessidades públicas: é preferivel que se reclame contra as administraçoes das municipalidades do que das empresas, porquanto se poderá com mais justica julgar do fundamento das reclamações e o próprio público poderá com maior facilidade corrigir o mal se quiser intervir com melhor critério politico na gestão dos negócios municipais (BRITO, 1912:2).

Em Recife, o Governo do Estado, através da sua Comissão de Saneamento, da qual Brito era integrante, havia encampado o sistema de abastecimento d'água que pertencia à Companhia do Beberibe, uma empresa formada por capitais locais e que possuía a concessão do serviço desde 1837. Na ocasião da encampação, o abastecimento da capital do Estado de Pernambuco se encontrava em situação bastante delicada com uma população de 217.000 habitantes distribuídos pelos 21.388 prédios e mais de 16.347 “mucambos" dentro do perímetro urbano, além de 17.783 prédios e 12.025 “mucambos” nos arrabaldes e subúrbios mais próximos de Recife. ${ }^{35}$

Este Relatório não foi concluido e publicado; portanto terão os politiqueiros de má fé e de má conducta mais uma ocasião de faz̧erem juízo errado de minhas intenções, porque não lhes convenha a boa interpretação da verdade. Pouco importa, porém, o dizer dos satélites dos governos; bastará que se saiba não ter o novo Governo aceitado o pedido de demissão que lhe submeti e ter revalidado as condições de liberdade de administração que o Governo anterior estabeleceu em 1909, na exemplar organisação da Commissão de Saneamento de Recife.

Diz̧ia eu, em princípios de 1911, no Relatório que será publicado opportunamente:

35 Ver BRITO, S. O saneamento das cidades do Brasil no centenário da independência - 1922. Obras Completas. Rio de janeiro: Imprensa nacional. 1944. p. 214. 
"Precisamos principalmente de propaganda, do estimulo e do espírito de justiça na dedicação à santa causa da saúde pública, de modo que ao se trabalhar por ella se conte com o apoio geral, e se não tenha opposição systemática a tudo e a todos, por mera politicagem ou por mesquinho interesse.

O inconveniente daquella expressão em terra de tantos extremos, não nos demove de a dizer. Ainda uma vez sirva de consolo (?) generalisarmos o mal, o apontado também existente e persistente para além do oceano, para terras da plena luz occidental. Por mais de uma vez. temos annotado e repetido as queixas e os conselhos de vários autores contra a nefasta influencia da política em questao de administração e de bygiene. Citemos agora o que acabamos de ler em um fascículoda revista $L$ 'E $A U$, de Paris $\left(n^{\circ} 2,15\right.$ de fevereiro de 1911). O titulo do artigo é expressivo: - Influência nefasta da política sobre a bygiene pública. Mostra o autor que a Allemanha está mais adiantada que a França, justamente porque lá o prefeito tem plena autoridade, plena consciência das suas funcçôes, e no exercício destas é respeitado pelos próprios adversárrios politicos. (REVISTA DE ENGENHARIA: 1912: 308)

A decisão pela estatização da Cia. do Beberibe teria sido influenciada por Saturnino de Brito, sempre contrário à gestão dos serviços de saneamento por empresas particulares, principalmente, em virtude de defender a abundância do abastecimento d'água para não comprometer o funcionamento dos esgotos, algo que fugia dos cálculos financeiros de qualquer empresa particular. Em Ribeirão Preto, Brito enfatiza a leitura de seu artigo publicado no número 11 da Revista de Engenharia do dia 10 de abril de 1912:

Em vários livros, relatórios e artigos Venho dirigindo um appello aos nossos engenheiros, para que não façam desta questão vital um assumpto de especulação mercantilista; para que não tirem destas obras o ganho proveniente da inconsciência na ambição ou na solvência menos escrupulosa de contractos não remunerados por deficiência de preço, por incapacidade de fiscalização ou por inépcia dos próprios empreiteiros na direcção dos trabalhos. Venho chamando a attenção dos nossos administradores para a responsabilidadee que lhes cabe em fazerem contractos para "saneamento", entregando aos azares de uma concorrência os estudos, a construção e a "exploração industrial dos serviços, ou uma só ou duas destas tres secções distinctas na phase evolutiva dos trabalhos. (REVISTA DE ENGENHARIA: 1912: 307)

Brito recomenda aos vereadores municipais a leitura do mesmo artigo em que havia exposto a situação política no contexto da estatização da Cia. do Beberibe. Mais à frente em seu artigo, o engenheiro irá escrever sobre suas concepções políticas e, consequentemente, a estrutura institucional que as administrações municipais brasileiras deveriam possuir:

Mas, o prefeito em Allemanha, o "bourgmaitre", não é eleito, é escolbido; em França o "Maire" é eleito. Prefeito eleito não é administrador, é creatura dos eleitores e adversário dos seus contrários em politica. É, o articulista pela vã politica". De um lado, elle aponta o prefeito eleito como "um prisioneiro do seu partido, em proveito do qual elle governa e administra, contra os seus inimigos políticos", "contra todos que não partilham cegamente suas doutrinas philosophicas". De outro lado, citando e apoiando as justas observaçôes de Aug. Rey, o celebre architecto-bygienista, sobre o mesmo assumpto, elle mostra quanto a acção benéfica do prefeito eleito fica prejudicada pela opposição política; para se ter ideia disto, diz que basta ler nas folhas locaes as violentas polêmicas a que dão lugar os menores actos de gestão municipal, transbordando, sem nenhuma continência, o ódio dos partidos; assim se terá ideia das difficuldades que encontra o prefeito, o mais consciencioso, para cumprir o seu dever sem fraqueza e sem parti-pris. Venha uma reviravolta de opinião ao curso de quatro annos, o partido contrario se installará na Prefeitura e com elle o espiritto de oposição; tratará de destruir o que fez. de bom e de justo. Este regimen pode pois se resumir em três termos: - incompetência, arbitrariedade, instabilidade. Um só destes vícios bastaria a condennar o systema, entretanto, elle subsiste. (REVISTA DE ENGENHARIA: 1912: 308)

O diretor da Empresa de Água e Esgoto de Ribeirão Preto contra argumenta a respeito da falta d'água alegando que ela ocorria em virtude da seca que afligia o município, mas também em 
razão do desperdício praticado pela população, algo que seria resolvido, segundo os argumentos de Flávio de Mendonça Uchoa, com a construção de caixas domiciliárias de abastecimento d'água. Com os hidômetros, o gerente aleva que regularizaria as cobranças das taxas do serviço, evitando o desperdício da população, além de contribuir com o aumento da renda da Empresa:

Os filtros no regime em que trabalham, $2 \mathrm{~m}^{3}$ por $1 \mathrm{~m}^{2}$, dão em 16 horas de serviço 2.400 .000 litros que addicionados ao volumes fornecidos pelos mananciais Schimidt-1.500.000 litros, Jardim, P.Vicente e S. Gertrudes - 1.400.000. Eleva-se a mais de $5.000 .000 \mathrm{em} 24$ horas o volume actualmente distribuido.

A cidade tem cerca de 2.400 casas abastecidas de água das quais 2.140 tocam 1.500 litros por casa ou 3.200.000 litros: admittindo-se ainda uma media absurda de 9 habitantes por casa teríamos uma populaşão de 21.600 habitantes que com 200 litros per capita exigiria 4.300 .000 para o algarismo das necessidades. A empresa fornece um excesso de $20 \%$ além do que é obrigada e, portanto, não deveria haver falta d'água. Quando em qualquer localidade o povo contrai o babito do desperdício d'água a própria administração pública se confessa impotente para corrigi-lo. (UCHÔA, 1912:3)

O diretor omite que havia sido distribuída pela Empresa água de forte coloração, e lamenta o abandono da captação do rio Pardo após a grande soma de capital investido sem, entretanto, discutir o melhoramento dos filtros propostos tanto pelo engenheiro da Repartição de Águas do Estado, Arthur Motta, quanto por Saturnino de Brito. Os melhores filtros permitiriam o abastecimento da cidade somente com as águas do rio Pardo, deixando os 2 milhões e 400 mil litros diários fornecidos pelos mananciais de "águas de fonte" - Schimidt (1 milhão e 500 mil litros); Jardim; Padre Vicente e S. Gertrudes (1 milhão e 400 mil litros) - para uma distribuição com sobra de água ou para a ampliação da rede para o restante da cidade.

O engenheiro civel Hyppolito G. Pujol Jr ${ }^{36}$ também apresenta à Câmara Municipal um memorial em resposta ao parecer do engenheiro francês $H$. Chabal, que havia criticado o seu projeto elaborado segundo as prescrições do engeheiro Arthur Motta e do prefeito Joaquim Macedo Bittencourt para o tratamento das águas do Rio Pardo pela Empresa de Água de Ribeirão Preto. O francês, gerente da Sociedade Puech Chabal \& Comp., discordava das formas dos dispositivos de tratamento propostos por Pujol Junior, alegando serem construtivamente mais caras do que as habitualmente realizadas pelo seu escritório. O engenheiro civil brasileiro, entretanto, discordava:

Passemos a examinar em detalhes essa critica, nem sempre razoável, refutando o modo de pensar do especialista citado, nos pontos em que se refere à economia da construção e a propriedade das formas adotadas - assumpto para o qual falece, evidentemente, a necessária competência ao engenheiro francês, que desconhece necessariamente as condições econômicas da construção no nosso país, mostrando, além disso, desconhecer inteiramente (a obstinada ignorância do francês de tudo que se passa fora da França) a larga aplicação que tem sido na Alemanha, na America do Norte, na Inglaterra etc. (PUJOL JR, 1913:1)

As polêmicas entre ambos os engenheiros giravam em torno do formato circular das bacias filtrantes projetadas Pujol Junior, que, segundo estudos da Sociedade Puech-Chabal, gerariam dificuldades para lavagem das camadas de areia e pedra usadas na filtragem. A forma circular dos

36 O mesmo engenheiro que em 1927 ganhará o concurso para a construção do conjunto arquitetônico do Quarteirão Paulista, sendo contratado por João Alves Meira Jr, presidente da Cia. Cervejaria Paulista, para realizar as modificações na fachada dos edifícios lindeiros a Praça XV de Novembro, ver SUNEGA, R. A. Quarteirão Paulista: um conjunto harmônico de edifícios monumentais. Ribeirão Preto: Fundação Instituto do Livro, 2011. 
filtros também impossibilitaria a instalação de comportas fabricadas e patenteadas pela empresa francesa. O engenheiro brasileiro, entretanto, alegava que seria possível garantir a limpeza dos filtros sem abandonar a forma circular ou aumentar o custo da obra, sendo o único ponto critico do projeto a dificuldade de limpeza dos pré-filtros. Essa manutenção exigiria o trabalho de um homem curvado, não escapando, portanto, da necessidade de trabalho braçal para a realização da limpeza dos filtros.

Porém, segundo o engenheiro, a impossibilidade de mecanização completa do sistema de filtragem das águas não seria uma exclusividade brasileira, também na França se exigia o trabalho braçal de limpeza. A visita das câmaras inferiores de filtragem no seu projeto, em contrapartida, se faria com dimensões mais humanas, acessíveis às descidas dos operários para a retirada do lodo.

Onde, portanto, a dificuldade de limpeza que acarreta a disposição por nós adotada, na qual as dimensões que acabamos de enumerar garantem - repetimo-lo - uma visitabilidade muito superior a da maioria dos projetos Puech-Chabal.(PUJOL JR, 1913:3)

Quanto ao que o engenheiro francês $H$. Chabal alegava a respeito da dificuldade de instalação das comportas especiais de fabricação de sua companhia, Pujol Junior é enfático:

É mesmo quase certo que isso se dê, pois, ao organizar o nosso projeto, não tivemos absolutamente intenção de aplicar tais aparelhos especiais, que são de patente da firma francesa, de sua fabricação exclusiva. Ninguém pretenderá que o que o engenheiro francês chama pomposamente de aparelhos especiais (simples comportas de comunicação e reguladores de nivel) constitua um material insubstituivel O mais modesto mecânico e a mais simples oficina de fundição se encarregarão de fornecer excelentes aparelhos, ou melhor, magnificas comportas adaptadas sob medida aos espaços disponiveis no nosso projeto. (PUJOL JR, 1913:4)

O ponto essencial da crítica do engenheiro francês $\mathrm{H}$. Chabal ao projeto de tratamento das águas do rio Pardo de H. Pujol Junior se referia à adoção, segundo as prescrições da Prefeitura Municipal, das mesmas áreas de superfícies filtrantes utilizadas pela Compagnie des Eaux de la Banlieue de Paris para filtrar as águas do rio Senna. Para Chabal isso era um erro devido à natureza das duas águas serem bastante diferentes. A alegação, entretanto, segundo Pujol Junior, advinha de um interesse do engenheiro francês pela sinalização da Empresa de Água de Ribeirão Preto encomendar a organização de um novo projeto junto à sua companhia.

Pujol Junior rebate a critica da seguinte forma:

Em primeiro lugar, em inúmeros projetos da firma Puech-Chabal, que temos sob os olbos, organizados para cidades as mais diversamente situadas na Europa, encontramos, sem poder deixar de sorrir, as superfícies filtrante calculadas quase na mesma relação constante com o volume de águas a filtrar... Será, o que nos enche de espanto, que todos os rios da Europa - o Elba, o Senna, o Rhodano, o Durance, o Loire e tantos outros, oferecem a firma Puech-Chabal, com uma amabilidade que nos encanta, a mais perfeita uniformidade na natureza das águas (PUJOL JR, 1913:6)

A decisão, que, segundo Pujol Junior, não prejudicava a filtragem das águas do rio Pardo, havia partido da Prefeitura Municipal diante de um parecer emitido por Arthur Motta, em 1902, para a captação de 6 mil $\mathrm{m}^{3}$ diários daquele rio. Assim, os cálculos do projeto da superfície dos filtros do engenheiro brasileiro seguia o que diretor da Repartição de Água e Esgotos do Estado de São Paulo havia estipulado. 
da identidade aproximada das águas do rio Pardo e do Senna (...) E, depois, sem nenhum intuito de lisonjear, preferimos nos manter nesta questão ao lado do Sr. dr. Arthur Motta, cuja a competência e cuja experiência nestes assuntos já lhe fizeram a reputação que todos conbecem e que não precisamos encarecer. Preferimos isso, sinceramente, a seguir supersticiosamente o conselho interessado do engenheiro francês, a quem a Empresa de Ribeirão Preto acenou com a possibilidade de, senão com a encomenda, da organização de um novo projeto. Isso parecerá certamente uma enormidade aos nossos patrícios, que entendem ser indiscutivel, sem exame de espécie alguma, a competência e a autoridade dos remotos profissionais, cujos trabalhos nos chegam com prestigio de uma data de Paris e de um nome arrevezado. (PUJOL JR, 1913:8)

Já o vereador J. P da Veiga Miranda prosseguia com os seus discursos da tribuna da Câmara alegando que a hipótese de se abandonar as águas do rio Pardo seria um crime imperdoável por somente existirem na cidade duas fontes que não reduziam de volume durante a seca - "as águas do rio Pardo e as águas do rio Preto". Como o ribeirão Preto já havia sido abandonado como fonte de água de distribuição em função da ocupação urbana de suas várzeas, restava apenas a opção de realizar os melhoramentos dos filtros d'águas do rio Pardo.

O abastecimento numa cota mais baixa favorecia a Empresa de Água, que poderia desprezar a construção dos tais filtros necessários para purificação das "águas de rio", bastando-lhe para o abastecimento dos 2.400 prédios da região central apenas as "águas de fontes” provenientes de antigos mananciais no interior de fazendas e chácaras: Schmidt, Jardim, Padre Vicente e Santa Gertrudes. Desse modo, estariam dispensados os 135 mil réis diários gastos para filtrar as águas dos rios com alumínio e cal.

O mapa 6 representa Ribeirão Preto na década de 1920, com a cidade cortada de sul a norte pelo ribeirão Preto. Esta era a cidade que atravessa a crise de falta d'água, nesse período ela já havia se expandido bastante para além de seu perímetro central onde se restringia a rede de água. Marcado pela confluência das avenidas Jerônimo Gonçalves e Francisco Junqueira, no mapa é possível enxergar o bairro República, a sudoeste, próximo ao ribeirão Preto e à linha da Cia. Mogiana, numa região baixa ocupada pelos funcionários da ferrovia e pelos operários das indústrias locais, que tiveram suas moradias muito afetadas pelas enchentes dos rios canalizados. Outros vetores de expansão da cidade eram ao leste, com a Vila Paulista, e ao norte, nos Campos Elíseos e no Ipiranga, que se originaram do antigo núcleo colonial de imigrantes e foram ocupados por moradias populares e indústrias.

Voltando à polêmica sobre o melhoramento dos filtros d'água. Na realidade, outra preocupação do diretor seria os gastos para realizar as desapropriações ao longo das margens do rio Pardo, que eram necessárias para garantir a qualidade das águas desse manancial:

As desapropriaçoes para o rio Pardo viria a custar cerca de 400 contos e depois de gasto esse capital colossal teríamos a certeza que nos anos de seca não o veríamos reduzido ao mínimo de se tornar insuficiente? Na época de calor [outubro à janeiro] quando mais se consome água é quando menos as fontes fornecem e infelizmente as nossas observaçöes mostram que o nivel dágua cada vez, baixa mais, indicio de baver menor armazenamento, fato este que todos os fazendeiros conbecem (UCHOA A, 1912:4)

Brito, em seu relatório, aborda esse assunto enfatizando a necessidade das desapropriações ao escrever sobre os pequenos mananciais, as chamadas "águas de fonte", tidas como de primeira 


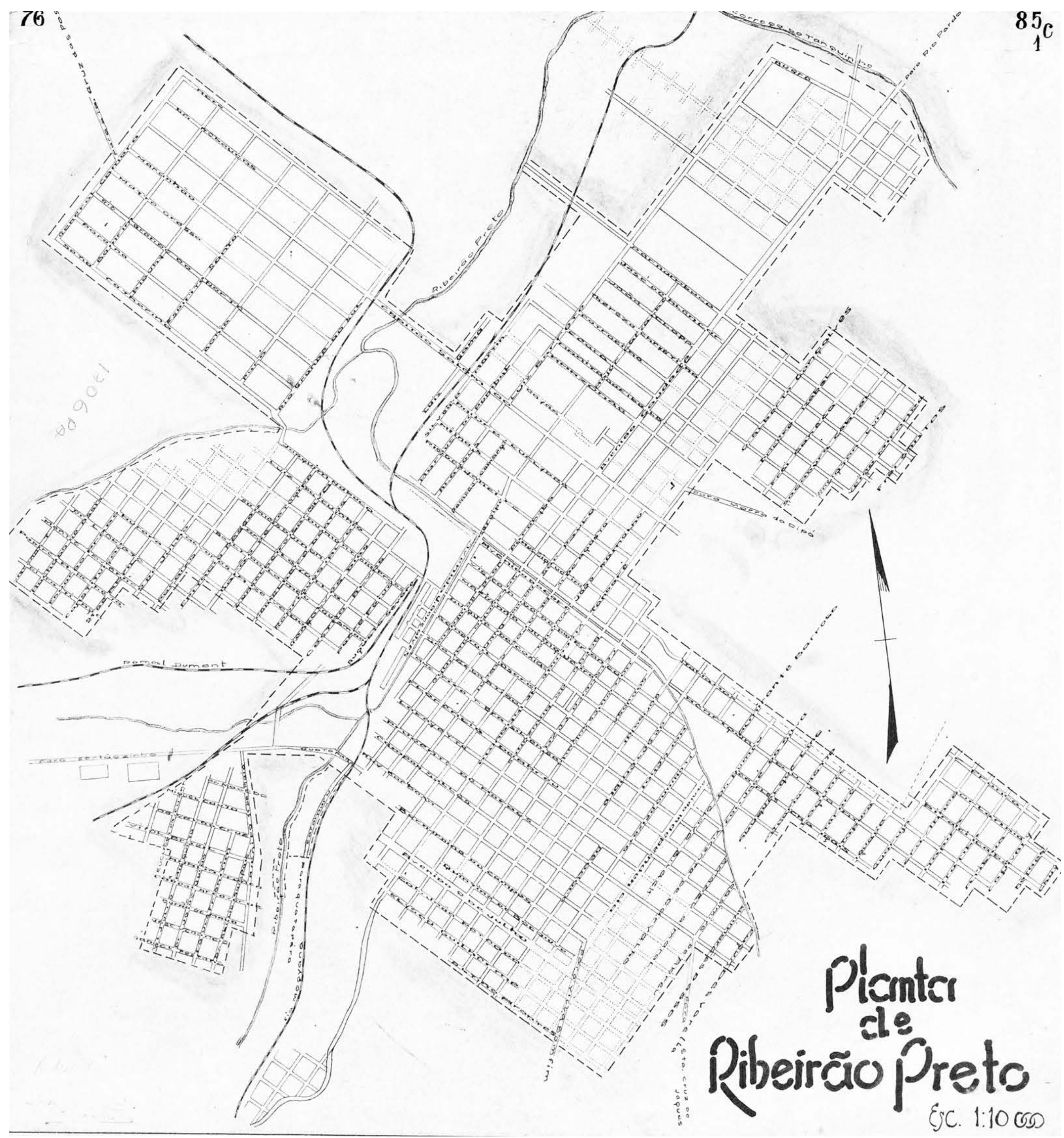


qualidade por toda população do município. O engenheiro dizia que a prefeitura não poderia dormir em descanso e se descuidar de uma fiscalização garantidora da pureza dessas águas, uma vez que elas poderiam ser maculadas em sua origem por habitações nos locais de captação. Este era o caso das águas do rio Pardo, poluídas, segundo Brito, pela quantidade excessiva de fazendas de café e colônias de imigrantes estabelecidos nas margens dos seus afluentes, o que aumentava muito a quantidade de matéria orgânica das águas. Para impedir a degradação da qualidade das águas pela lavoura de café, Brito estabelece:

Esta situação indica dupla medida, uma preventiva, outra corretiva, ambas de competência do Estado: $1^{a}$ a lei de proteção dos cursos d'água, para a necessidade da qual apelamos no estudo sobre o Abastecimento d'água de São Paulo. $2^{a}$ o saneamento agrícola das margens do rio Pardo e seus afluentes drenando estas superficies, certamente ubérrimas, e as cultivando. E possivel que este serviço de drenagem e de cultura seja indicado para os lavradores japoneses, procurando garantir-lhes a vida durante a fase de trabalho saneador. Para o Estado há o grande proveito industrial de desenvolver outras culturas, garantidoras dos acidentes depreciadores da sua grande lavoura de café (BRITO, 1912:8)

Na cidade Campinas, numa região que também havia sido ocupada por fazendas de café durante a segunda metade do século XIX, Brito, ao elaborar o seu projeto de regulamentação para os serviços de águas, também estabelece uma lei de proteção aos cursos d'água e aos mananciais, para que não fossem poluídos tanto pela ocupação urbana quanto pela atividade produtiva das fazendas de café. A realização de lavagens dos grãos e a ocupação das colônias de trabalhadores sempre nas margens de rios e açudes, além das enormes plantações deste produto de exportação, faziam com que a presença das fazendas de café fosse bem mais prejudiciais aos cursos d'água do que outras culturas agrícolas voltadas a alimentação e subsistência.

Em Campinas, Brito estabelecia o seguinte:

Art. 1. Nas propriedades em qualquer tempo adquiridas pela Companbia para garantir a pureza das águas dos pequenos mananciais será impedida a habitacão, mesmo a dos guardas do serviço, nas áreas vertentes para ditos mananciais a montante das respectivas represas de tomada; serão demolidas as casas existentes nessas áreas e impedida a permanência de animais domésticos.

Art. 2. Nas propriedades particulares existentes nos terrenos vertentes para os mesmos pequenos mananciais, à montante da represa correspondente, será proibida a contaminação das águas por despejos nocivos, provenientes dos moradores, das indústrias, de estábulos, pocilgas, estrumeiras, lavadouros de café etc ; outrossim, será proibido o uso de adubos e ingredientes nocivos em condiçoes destinados à alimentação potável, a juirzo das autoridades sanitárias do Estado.

Parágrafo único. A Câmara Municipal providenciará junto do Governo do Estado para que the sejam assegurados os meios legais para tornar efetiva a proteção dos cursos na propriedade particular. (BRITO: 1944: 129).

Essas demandas por leis de proteção dos cursos d'água, com as desapropriações de terrenos marginais aos mananciais, estão no cerne de uma visão ambientalista da teoria urbanística do engenheiro Satunino de Brito. O engenheiro é um dos pioneiros na defesa pela implantação de políticas com esse cunho, como, por exemplo, no caso de suas proposições de reflorestamentos de áreas desmatadas em processos de aberturas de fazendas de café em Ribeirão Preto.

A excessiva turbidez das águas que a Empresa havia distribuído na cidade tinha origem 
na drenagem dos afluentes do rio Pardo pelas estradas e carreiros dos cafezais. As chuvas nas plantações de café carregavam argila e poeira fina, promovendo a desagregação do terreno, formando "barrocas" ou "mossorocas", fenômenos que deveriam ser corrigidos através do desvio de águas ou pela arborização. Brito propõe a desapropriação dos terrenos das fazendas de café que eram marginais aos mananciais de captação d'água para que fossem reflorestados e habitados por colonos que cultivassem outras culturas agrícolas para amenizar a degradação das grandes monoculturas cafeeiras.

Sobre essa visão ambientalista de Brito, Andrade (1992: 222) alega o seguinte:

Há ainda um aspecto da teoria de Brito que precisa ser destacado - a sua visão ambientalista. Ainda que ambigua, como vimos em sua posição em relação à poluição dos cursos d'água por esgotos urbanos, ela está presente na sua preocupação com a preservação de mananciais, através da conservação das matas. Por outro lado, convicto de que a causa da insalubridade urbana localizava-se em águas estagnadas, defenderá o aterro de mangues, pântanos e brejos, o que, em geral, se faz̧ia por meio da terra obtida do desmonte de morros. Para se garantir uma ventilaşão urbana adequada o relevo poderia ser alterado e o fundo do vale era bastante redefinido com a retificação e canalização dos rios, levando à destruição do ecossistema varžeano, embora em seu projeto de melhoramentos para o Tietê, em São Paulo, tenha sido preservado.

A proteção da várzea do rio Tietê no projeto de Brito associava, portanto, a posição sobre o abastecimento urbano com águas de rios. Notamos também que essa visão ambientalista em relação à proteção dos mananciais advinha de sua interlocução com os engenheiros sanitaristas francesas, como no caso de profícua relação com o Dr Imbeaux, que irá condecorar Brito em 1916 como membro de honra da Exposição de Cidades Reconstruídas, sendo convidando a escrever o livro Notes sur le tracé sanitaire de villes. Sobre esse engenheiro francês, Brito retira as seguintes sugestões para a proteção das águas:

O melhor modo para realizar esta proteção consiste na aquisição por inteiro das bacias que alimentam as fontes, poços, drenagens, e mantê-las desertas ou cobertas de bosque. Quando não for possivel esse alvitre, épreciso manter o respeito às águas por meio de regulamentos severos, pelos esgotos normais e depuração de todos os despejos (sewage) e águas nocivas na região interessada. Se semelhante proteção não puder ser realizada com segurança, a água deve ser rigorosamente filtrada ou esterilizada antes de ser entregue ao consumo (BRITO: 1944: 40).

Por último, a fim de não descartar o aproveitamento das "águas de rio", Brito cita no seu relatório os estudos feitos para purificação do canal de abastecimento da cidade de Marselha. As análises comprovariam a possibilidade de captação de águas impuras, tendo sido retirado do canal, antes de se levarem as águas ao abastecimento, uma infinidade de cadáveres de animais, além de alguns defuntos humanos. A aplicação da Lei de Proteção de cursos d'água francesa, além de um processo de purificação enérgico contra a matéria orgânica proveniente das numerosas aglomerações humanas ribeirinhas (usinas, lavadeiras etc), havia possibilitado em Marselha a rejeição das "águas de fonte", assumindo-se o processo de purificação das águas de seu canal urbano:

Depois de vários estudos, ficou rejeitado o alvitre de procurar "água de fonte" e aceito o de purificar aquelas águas, comparadas às quais são puríssimas as do rio Preto e as do rio Pardo. Submeta-se o tratamento a um concurso no qual a questão principal é a esterilização e não simplesmente a clarificação de que precisamos para as águas do rio Pardo (BRITO, 1912;10).

Nessa perspectiva, as águas do ribeirão Preto e do rio Pardo, segundo Saturnino de Brito, 
podiam ser consideradas puríssimas em relação às do canal de Marselha. Essa decisão pela captação de águas de rios acompanhava o que ele havia proposto para o abastecimento da zona baixa da cidade de São Paulo, que em virtude da grande demanda e dos sacrifícios para provimento dessa região em virtude da diminuição dos mananciais da Serra da Mantiqueira em época de estiagem, Brito sugere o seu abastecimento sob o seguinte lema: "as águas altas para as zonas altas, as águas baixas, especialmente as de rio, para a zona baixa". Este era o caso do bairro do Brás, para o qual sugere a tomada de águas do rio Tietê.

Todavia, o engenheiro ressalva o imprescindível tratamento purificador para estes casos, sendo algo que não foi feito em São Paulo, gerando acaloradas discussões de opinião pública quanto ao Governo adotar o abastecimento da zona baixa e média da cidade pelo rio Tietê.

Com efeito, atualmente a opinião pública apresentava contra a utilização das águas do tiete a má construção de uma galeria filtrante, sem as precisas condições de semelhante recurso. A galeria, deixando de satisfazer com a quantidade d'água precisa, se rompeu e as bombas dai por diante tomam a água do rio, pura como está, e a injetam na rede do Bra‡. São distribuidos cerca de 4 milhões de litros de águas turvas, com o afanoso trabalho de seis bombas que, pelo ruido das engrenagens, dão ideia do valor de uma instalação tão primitiva em uma cidade tão progressista. É verdade que, por um destes desmentidos que a pratica faz às previsões dos higienistas doutrinários e rigoristas, a água do Tiete, sem filtração alguma, turva como corre, colbida na margem a menos conveniente, a jusante da povoação da Penha, junto da fábrica de sabão, etc, etc, etc - não colabora para que seja maior a mortalidade do bairro baixo, - aquele em que se aglomera a população menos asseiada, em que as edificaçoes são menos "sanitárias" e em que o terreno, baixo e úmido, por si deveria concorrer para a depressão mórbida na constituição médica regional. É o que se colbe do que disse o eminente diretor do serviço sanitário, o Sr. Emilio Ribas, sobre a salubridade do Braz e sobre o abastecimento pelo Tietê, convenientemente tratado.

Em Ribeirão Preto, Brito irá avaliar como positiva a iniciativa da Empresa de captar as águas do rio Preto em função da falta d'água. Porém, apesar das análises dessa água ter sido favorável, sinalizando pela possibilidade de um tratamento purificador, as condições do curso do ribeirão Preto geravam muita desconfiança na opinião pública e na Câmara Municipal. Além disso, o processo adotado pela Empresa não havia amenizado as desconfianças do público quanto às águas que corriam às suas vistas, recebendo contaminações, e deixando-os incrédulos sobre os êxitos na purificação. Brito alega que ao menos as indústrias de maior consumo não deveriam captar água de distribuição, estabelecendo um preço proibitivo a isto tendo em vista a facilidade delas realizarem a própria captação no ribeirão Preto. Transparece, dessa forma, uma divisão sócio espacial do município semelhante àquela de São Paulo, ou seja, entre zonas altas e zonas baixas, o abastecimento d'água de fábricas e indústrias na zona norte da cidade seria realizado pelo caudal do ribeirão Preto com águas in natura.

Por fim, o líder da Comissão Especial das Águas, o vereador João Alves de Meira Junior, também presidente da Câmara Municipal, e aliado político de Junqueira, promove a conciliação entre a Administração Municipal e a Empresa de Água da família Silva Prado. Essa conciliação demostra mais uma vez os arranjos apenas conjecturais dos grupos políticos instalados na Câmara Municipal, tendo em vista que nesse caso se vê os políticos aliados de uma família de entrantes mineiros se conciliarem com a Empresa da principal família de migrantes do Vale do Paraíba. O acordo contrariava diversas críticas e propostas apresentadas nos pareceres tanto do vereador J. P. 
da Veiga Miranda quanto nos relatórios dos engenheiros contratados pela Câmara Municipal. João Alves de Meira Junior dizia o seguinte em seu relatório:

Ao assumirmos o governo municipal encontramos a Empresa de Àgua e Exgottos com a concessão para abastecer a cidade com água do rio Pardo. Mandando proceder ao exame dos trabalhos de captação e filtros da mesma água e a analise desta, não consentimos na sua distribuição a população sem as obras complementares que nos foram indicadas pelos drs. Artbur Motta, Saturnino de Brito e H. Pujol Junior.

Não querendo, porém, desde logo a Empresa se submeter a essas obras, estudamos com ela a melhor forma de fazer cessar a falta d'água de que toda a população se queixava. Foi então averiguado que a água das nascentes era suficiente ao abastecimento da cidade, estando o defeito no regime de pennas, o qual foi substituído pelo regime dos hidrômetros, fixando uma taxa mensal mínima e o limite de 45 mil litros para cada babitação. E, assim, ficou resolvido o problema, pois que há muitos annos a populção não sente falta d'água, apesar de actualmente ser maior a zona servida pela Empreza, visto que, então, Villa Tibério não tinha água nem exgottos.

A água do rio Pardo foi banida da rede geral. (MEIRA JUNIOR: 1920: 16-17).

O desfecho da crise do abastecimento d'água de 1912 na cidade de Ribeirão Preto foi, portanto, o abandono da captação e filtragem das águas tanto do ribeirão Preto quanto do rio Pardo, uma vez que ficou decidida a suficiência das águas de nascentes em proveito dos interesses da Empresa e dos proprietários dos mananciais de "água pura" - Fazenda Schmidt; Jardim e chácara do Padre Vicente. O problema da falta d'água, segundo as autoridades municipais, era decidido pelo desperdício praticado pela população atendida pelo regime de penas, o que seria corrigido com a instalação das caixas domiciliárias como havia sido proposto pela Empresa, em detrimento da ampliação da rede de abastecimento e com o aumento das taxa de água a população.

Nesse ponto, os argumentos de Saturnino de Brito em relação à instalação dos hidrômetros são apropriados e distorcidos pela Empresa e pelos vereadores. Contra o desperdício de água, Brito havia proposto uma captação excedente, que seria necessária em função do sistema de penas, sem caixa domiciliária, estando a população acostumada a um franco desperdício, mas que também favoreceria a expansão da rede. Brito é enfático, alega que pouco importa ser a Empresa a concessionária do serviço, a economia de água era algo a que se devia empenhar a administração municipal, cortando serviços não remunerados e abusos no consumo, pois o gasto d'água inutilmente causaria prejuízos ao próprio público. A situação de desperdício era inconveniente nas aduções por gravidade, e muito mais onerosa nas aduções mecânicas, como no caso das águas do rio Pardo. Segundo o engenheiro, não cuidar da regularização do consumo pesaria sobre a municipalidade no futuro quando os serviços estivessem estendidos e retornassem à administração do município. Desse modo, o que Brito propunha não era exatamente o que foi realizado pela Comissão das Águas da Câmara Municipal em aliança com a Empresa de Água da família Prado. Sob o argumento de se evitar o desperdício, os trabalhos são encerrados com o abandonado da construção de filtros para a captação das águas dos rios, além do aumento das taxas de água sem ampliar a rede de abastecimento. 

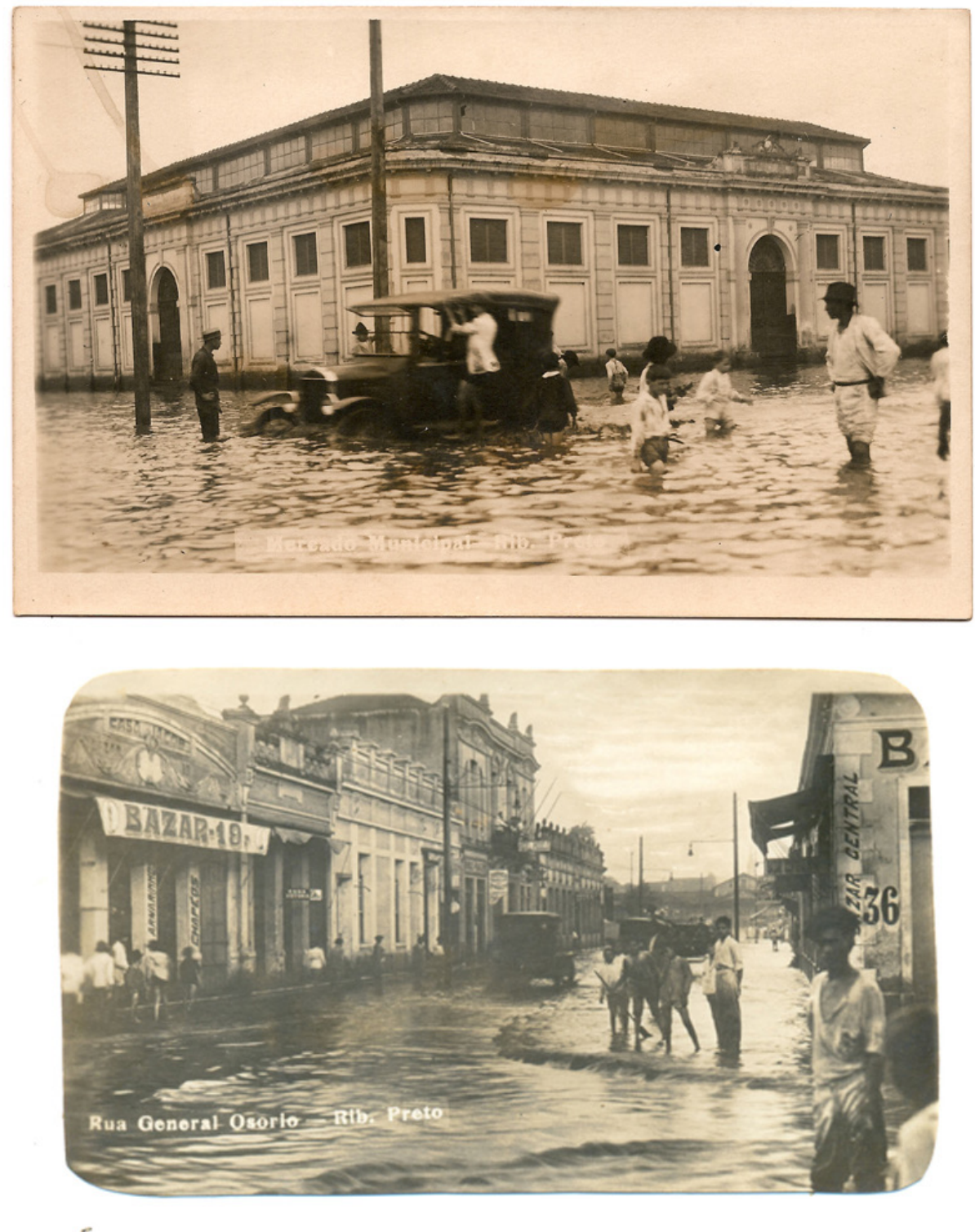

Figura 19 e 20: A ambiguidade da tentativa de controle das águas na cidade de Ribeirão Preto. O Mercado Municipal durante a enchente de 1927 que havia sido o objeto do empréstimo realizado por J. P da Veiga Miranda para a sua encampação. Abaixo a Rua General Osório no sentido da Estação. Os alagamentos passam a se tornar recorrentes após as obras de canalização e drenagem dos rios sem que essa água fosse incorporada ao abastecimento do município. Fonte: APHRP.

\subsection{O monopólio sobre os recursos hídricos.}

O desenrolar da década de 1910, após o desdobramento da polêmica sobre os mananciais da cidade, é acompanhado pela consolidação da força institucional da Empresa de Força e Luz de Ribeirão Preto. Essa Empresa, ao absorver a Empresa de Água e Esgotos, irá atuar no sentido da formação de um monopólio sobre os recursos hídricos, não só da cidade, mas de mananciais abundantes para o abastecimento d'água, e também de corredeiras com potencial energético existentes num vasto território do Nordeste Paulista. Assim, a Sociedade Anônima, Empresa de Força e Luz de Ribeirão Preto, através da compra de concessões que pertenciam a outros 
engenheiros locais, adquire os contratos dos serviços de eletricidade, iluminação, abastecimento d'água e coleta de esgotos de inúmeras Câmaras Municipais de cidades do Interior Paulista.

Essa Empresa já existia desde 1898 sob a direção de Rufino Augusto de Almeida, porém ela passa a ser propriedade de um grupo de empresários de São Paulo, que mantinham sede na capital, e Flavio de Mendonça Uchoa, como o procurador e administrador na cidade de Ribeirão Preto. O repasse do contrato celebrado com Rufino A. de Almeida é realizado durante a gestão de J.P. da Veiga Miranda, como Prefeito Municipal, em 1909. Segundo Lima (2004), no momento da aquisição da Empresa de Força e Luz pelo grupo de acionistas da família Silva Prado, já se distribuía energia através de uma modesta Usina Hidrelétrica montada no centro da cidade, utilizando as pequenas corredeiras do ribeirão Preto.

Essa criação de queda correspondia, em grande estiagem, a menos de 100 cavalos. Basta dizerer que a cidade, por esse tempo, já contava com cerca de 1800 casas, para revelas a insuficiência da primeira instalação em relação ao serviço de iluminação pública e particular (...) Decorridos dois anos, como se não fosse possivel obter nas proximidades novos recursos hidráulicos reforçou-se a usina Electra com mais uma unidade geradora (CAPRI apud LIMA: 2004: 51)

Em virtude do crescimento da cidade e a demanda gerada pelas fazendas de café, a capacidade desta usina torna-se limitada, o que faz com os acionistas paulistanos vislumbrem uma oportunidade de ampliação dos negócios, promovendo a fusão dos serviços de Água e Luz sob a mesma administração de Flávio de Mendonça Uchoa. Na abertura do livro de estatutos e contratos da Empresa de Força e Luz, é possível ver as cláusulas do contrato estabelecido com a Câmara Municipal, o que transparece os objetivos da criação da Empresa ao se tornar uma Sociedade Anônima:

\author{
ESTATUTOS \\ da \\ Empresa Força e Luz de Ribeirão Preto \\ 23 de Abril de 1912 \\ $A R T 1^{\circ}$
}

A sociedade em Commandita por açôes - Empresa Força e Luz de Ribeirão Preto - sob a firma de "Rufino A. de Almeida e Comp." Fica transformada em sociedade anonyma, sob a denominação de Empresa Força e Luz de Ribeirão Preto.

ART $2^{\circ}$

Esta sociedade tem por fim:

a) Montar e explorar o serviço de iluminação electrica de Ribeirão Preto, de acordo com o contracto entre a Câmara Municipal dessa cidade e o engenheiro Rufino A. de Almeida:

b) Montar e explorar uma fábrica de carbureto de cal, aproveitando os elementos das instalações electrica de Ribeirão Preto, ou de qualquer outra que venha a montar:

c) Obter contratos e privilégios nos municípios vizinhos para exploração de força e luz e serviço de água e esgoto (EMPRESA DE FORÇA E LUZ: 1912: 5)

Numa outra passagem do seu livro de estatuto, referente à transcrição da ata de uma assembleia geral dos acionistas da Empresa, é possível identificar os seus integrantes. Entre eles se destacam o presidente da diretoria, Plínio da Silva Prado, e os demais representantes de todo o capital social: Joaquim Mendonça Filho, Luiz Alves de Almeida, Caio Prado, Luiz Rudge Ramos, 
Francisco Rodrigues Lavras, Renato Ramos e Pedro Luiz Pereira de Sousa. Na ocasião da reunião realizada no dia 26 de abril de 1910 na cidade São Paulo, os acionistas votavam pela elevação de capital, como pode ser observado mais à frente no livro de estatutos e contratos da Empresa:

\section{EMPRESTIMO DE 1.200:000\$000 EM DEBENTURES}

(20 de agosto de 1910)

PRESTAMISTA: William Fox Rule, representante dos debenturistas. MUTU ÁRIA: Emppresa Força e Luz de Ribeirão Preto. $2^{\circ}$ Tabelião da Capital certidão liv. 234, fl.31

Escriptura de empréstimo com emissão de debêntures.

Saibam quantos esta publica escriptura virem, que no anno do nascimento de Nosso Senhor Jesus Christo de mil novecentos e dez, aos vinte dias do mez de agosto, nesta cidade de São Paulo, capital do Estado do mesmo nome, da Republica dos Estados Unidos do Brasil, em meu cartório, perante mim tabelião interino, compareceram partes entre si justas e contractadas, a saber: como outorgante devedora a Empresa Força e Luz de Ribeirão Preto, sociedade anonyma com sede nesta capital, neste acto representada por seu director presidente Dr. Plinio da Silva Prado, e como outorgado credor William Fox Rule, corretor official desta praça, como representante dos portadores das obrigacões preferenciais (debêntures), ambos meus conhecidos e das testemunhas adiante nomeadas e assignada, do que dou fé. (EMPRESA DE FORÇA E LUZ: 1912: 167)

Outro empréstimo realizado desta vez entre capitalistas franceses pode ser observado no seguinte contrato:

\section{EMPRESTIMO DE TRES MILHOES DE FRANCOS}

$\left(1^{\circ}\right.$ de maio de 1912)

Prestamista - Société Financiére et Commerciale Franco Brésilienne.

Mutuária - Empresa de Força e Luz de Ribeirão Preto.

$2^{\circ}$ Tabeliao da Capital Certidão Liv. n. ${ }^{\circ}$ 260, fl 62v.

Escriptura de divida, bypotheca, penhor e fiança. (EMPRESA DE FORÇA E LUZ: 1912: 175)

A garantia de pagamento de tais empréstimos, incluindo os juros e amortizações, além das eventuais multas aplicadas ao contratado, estava escriturada na forma de hipotecas e penhor dos inúmeros bens de raiz possuídos pela Empresa de Força e Luz de Ribeirão Preto. Como pode ser conferido a seguir:

a) A cachoeira da "Fervura" com as suas respectivas faixas de terras, a margem esquerda e a margem direita do rio Sapucaby-Mirim, situadas na freguezia de Nossa Senhora do Carmo, município e comarca de Ituverava, e na freguezia de S. Joaquim, municipio e comarca de Nupuranga (...) Fica comprhendida neste immovel a barragem já terminada no Rio Sapucaby para prduçãoo de uma força equivalente a cinco mil cavallos, todo o canal numa extensao de mil e durentos metros, a casa destina a usina geradora, as casas para o pessoal e os materiais já depositados;

b) A cachoeira dos "Dourados "(com uma força aproveitável de cerca de dois mil cavallos) e suas respectivas faixas de terras, a sua margem esquerda e a sua margem direita do rio Sapucaby (...)

c) Um terreno em Ribeirão Preto,situado a rua do Commercio $n^{\circ} 36$, com cento e trinta e dois palmos de frente e treze de fundos, confrontando com a rua Visconde do Rio Branco, onde mede cento e trinta e dois palmos, com a rua Alvares Cabral e com o terreno em que está edificado o Frontao, na freguezia, município e comarca de Ribeirão Preto, terreno esse em que se acha construida a casa para o escriptorio central da Empresa e a respectiva sub-estação no Ribeirão Preto (...)

d) Um terreno sobre o qual foi construida a sub-estação de Cravinhos (...)

e) Um terreno sobre o qual foi construida a subestação de Villa-Bonfim (...) (EMPRESA DE FORÇA E LUZ: 1912: 178) 
Diversos outros terrenos e privilégios de exploração de contratos entram como o penhor da capitalização realizada pela Empresa através de empréstimos entre bancos ingleses e franceses. Logo, a absorção dos contratos e privilégios nos municípios vizinhos passa a ocorrer contemporaneamente à conclusão das obras da Usina Hidrelétrica de Sapucahy-Mirim, a 69 quilômetros de Ribeirão Preto, próximo a São Joaquim da Barra, aumentando a capacidade energética da Empresa, tornando-a uma das mais importantes do país.

No livro da Empresa, podemos conferir a absorção dos contratos das seguintes cidades do Interior Paulista: Município de Ribeirão Preto (concessão para o fornecimento de Força e Luz, além da Concessão do Serviço de Água e Esgoto); Município de Cravinhos (Concessão para o fornecimento de Luz Elétrica; além da Concessão dos Serviços de Água e Esgoto); Município de Nuporanga (Concessão primitiva de electro-via, além do Privilégio para fornecimento de Força e Luz); Município de Jardinópolis (Concessão para exploração dee eletricidade em todos os seus usos e aplicações); Districto de Brodowski (concessão para Água, força e luz); Município de Sertãozinho (Concessão para Iluminação Pública e Particular).

Sobre a constituição desse monopólio sobre os recursos hídricos do Interior Paulista, Lima (2004) faz a seguinte citação:

Os estudos preliminares a que se procedeu dentro de um circulo de 100 kilometros de raio demonstraram que a solução mais conveniente consistia na utilização das quedas do rio SapucabyMirim, a 69 kilômetros de Ribeirão Preto, quedas estas que foram adquiridas pela Empreza. Sommam ellas 10.000 cavallos em dois pontos do curso do rio, distanciados de cerca de 18 kilometros.

Dada à importância das obras, a Câmara Municipal, vendo que se tratava de uma questão de interesse geral para o município, pronptificou-se a cercear de garantias e capital necessário a sua execução.

De tal sorte refundida em novos moldes foi alargando o campo de ação pelos municípios vizinhos, jápela obtenção de concessões novas, já pela compra de contractos existentes, ou de empresas anteriormente organizadas e em exploração.

Sua zona priviligiada, de extensão superior a dois mil e duzentos kilometros quadrados, comprehende hoje seis municípios limitrophes, que são os seguintes: Ribeirão Preto, Cravinhos, Sertãozinho, Jardinópolis, Brodowski e Orlândia.

Nella se acham comprehendidas mais de 250 fazendas de café cuja producão annual é superior a seis milhões de arrobas, ou um milhão e quinhentas mil saccas, isto é, cerca da metade de toda a produção da zona servidda pela Estrada de Ferro Mogyana. (CAPRI: 1913: 299 apud LIMA: 2004: 57)

A zona de mais de dois mil e duzentos quilômetros quadrados compreendia, justamente, aquele território do Nordeste Paulista que Martinho da Silva Prado desbravara ao final do século XIX, junto a Luis Pereira Barreto, frente aos antigos povoadores mineiros que haviam dominado a Câmara Municipal de Ribeirão Preto.

Para receber e distribuir a energia gerada pela nova usina do rio Sapucahy-Mirim, foram construídas diversas subestações em Salles de Oliveira, Jardinópolis, Bonfim Paulista, Guatapará, Sertãozinho e Cravinhos. Estas edificações foram realizadas segundo projeto modelo feito por Victor Dubugras, sendo repetido pela Empresa naquelas diversas cidades. A relação desse arquiteto com família Prado vinha de 1897 quando Dubugras elaborara um projeto de restauro para um 
edifício de Arthur Prado na rua Vergueiro, em São Paulo. Em 1902, Dubugras também irá realizar os projetos de residências de Flávio de Mendonça Uchoa, em São Paulo, e a casa-sede da Fazenda São Martinho, em Ribeirão Preto. Tal contato entre a família e o arquiteto advinha da presença de Flávio de Mendonça Uchoa e Victor Dubugras no Departamento de Obras Públicas do Estado de São Paulo.

Dubugras irá projetar o escritório central da Empresa de Força e Luz, em 1909, numa quadra central na cidade de Ribeirão Preto. Edifício, inclusive, que entra como penhor naquele processo de capitalização realizado por Plínio da Silva Prado:

a Empreza, há cerca de três annos adquiriu em situação bem central, isto é entre as ruas do Commercio, Alvares Cabral, Tibiriçá e Visconde do Rio Branco, um vasto terreno medindo $7560 \mathrm{~m}^{2}$ onde implantou as construcões acima referidas [escritório central, almoxarifado, oficinas, depósitos e casa de empregados] (CAPRI: 1913: 319 apud LIMA: 2004: 53)

O Almanach Ilustrado de 1911, uma revista bilíngue (português/francês) organizada por Martinho Prado Junior com o intuito de divulgar o progresso de Ribeirão Preto ao país e à Europa, inicia o tópico sobre a Cia. de Força e Luz, assim:

O Estado de São Paulo, rico em iniciativas de primeira ordem, conta no município de Ribeirão Preto, em pleno funcionamento, uma das mais poderosas empresas particulares, destinada a um belíssimo e grandioso futuro. É a Companbia "Força e Luz" organizada e dirigida technicamente pelo ativíssimo e competente engenheiro brasileiro, Dr. Flavio Uchôa, um dos mais completos espiritos yankee (Almanach Ilustrado, 1911:113).

Nesse momento, a Empresa de Força e Luz já fornecia energia elétrica para diversas fazendas realizarem o trabalho de beneficiamento do café, além de prover a iluminação pública daqueles municípios da região. O Almanach Ilustrado ainda apresenta o seu capital de cinco mil contos de réis, sendo um dos maiores acionistas o Dr. Plínio Prado, diretor da casa de exportação de café Prado Chaves \& Cia.

Já o Almanach O Brasil Illustrado de 1922, também elaborado para exaltar os feitos do Estado de São Paulo no que se referia ao comércio, a indústria e a agricultura, apresenta a Empresa de Força e Luz como uma das grandes iniciativas da cidade de Ribeirão Preto e do Estado de São Paulo, ao lado do Theatro Municipal de Ramos de Azevedo e da Estação da Luz da São Paulo Railway. O Almanach editado sob homenagem ao presidente da República Epitácio Pessoa, estampava também em suas paginas iniciais os proeminentes políticos do estado, como o governador Altino Arantes. Antes de elencar as iniciativas da Empresa, o Almanach dá um panorama da composição dos municípios do Estado:

O Estado de S. Paulo é dividido em 174 municípios, nos quaes são distribuídas cidades e aldeias - Capital do Estado é S. Paulo. sabe-se que é uma das mais bellas e modernas cidades da America do Sul, cuja população se avalia hoje em meio milhão de habitantes. A segunda é Santos, principal porto do Estado e cidade muito commerciante de cerca de 100.000 habitantes. Campinas, com cerca de 50.000 habitantes, centro de vastas culturas de café. Ribeirão Preto, centro das maiores culturas de café do Estado, onde se acham as mais vastas e modernas Dazendas, com cerca de 40.000 habitantes, a maior parte dos quaes são italianos.outras cidades são Jundiaby, Rio Claro, S. Carlos, Jabú, Piracicaba, Sorocaba, esta com boas fabricas de tecidos, Cananéia, e Iguape, importantes pelas vastas plantações de arroz, sendo estas duas portos de cabotagem marítima. (O BRASIL ILUSTRADO: 1922: 10) 


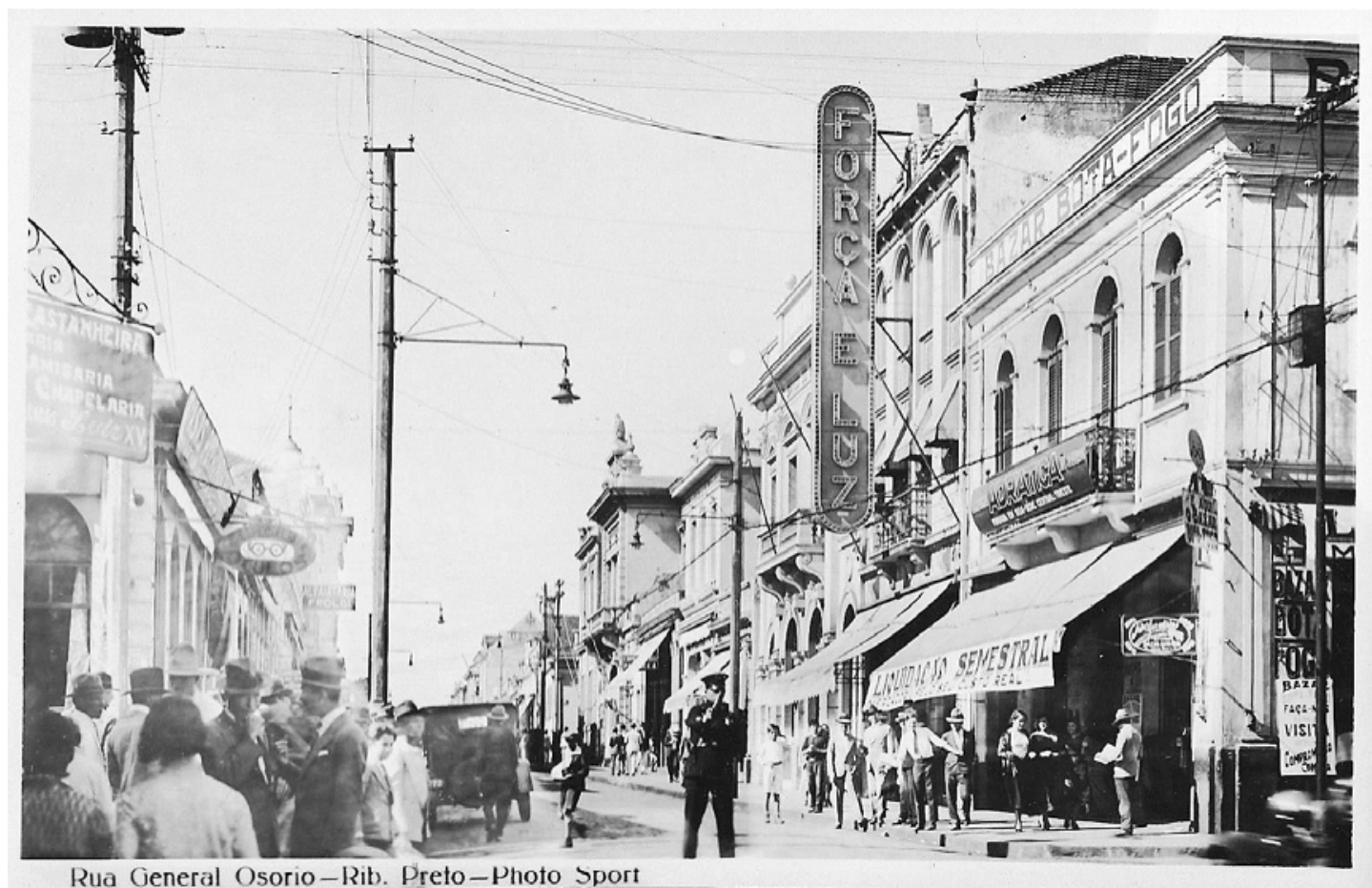

Figura 21: Um dos edifícios da Empresa de Força e Luz de Ribeirão Preto modificando a paisagem noturna do centro da cidade ao instalar o seu outdoor luminoso, além dos postes iluminação ao longo da rua General Osório. Fonte: APHRP.

Dessa maneira, a Empresa de Força e Luz se consolida na região de Ribeirão Preto como mais um dos negócios da família Silva Prado no bojo da expansão cafeeira paulista. As articulações políticas e institucionais da Empresa ao longo das primeiras décadas do século XX possibilitaram que a família Prado, através de seu procurador Flavio de Mendonça Uchoa, agregasse progressivamente os diversos contratos de concessão de serviços urbanos relacionados aos recursos hídricos da região.

A relação de parentesco entre Flavio Uchoa e os Silva Prado remonta a um processo de constituição de alianças familiares no sentido do que Darrel Levi (1977) definiu pelo conceito de família de elite modernizante. Ou seja, através das suas alianças familiares os integrantes dos Silva Prado procuraram se diferenciar do modelo patriarcal da família brasileira fundiária. A família extensiva dos Prado, no período de 1840 a 1930, se constitui de uma linha de primos ricos e influentes da cidade - proprietários de fazendas rurais, mas com sua base na cidade de São Paulo. Desse modo, em virtude das preocupações políticas, econômicas e culturais dessa linhagem da família, ocorre o enfraquecimento da solidariedade familiar com ramos de primos mais pobres do interior que possuíam status mais obscuros. Assim, os Prado mais influentes irão reconstituir seus laços de parentesco com famílias de status e interesses semelhantes, ou com figuras de classes profissionais que representavam a avant garde do progresso e da modernização social.

A própria trajetória do engenheiro Flávio Uchoa demonstra esse processo - nascido em Estância, no estado de Sergipe, após formar-se na Escola Politécnica do Rio de Janeiro, inicia sua carreira na construção de Estradas de Ferro no Rio Grande do Sul, início profissional semelhante ao de Saturnino de Brito no Nordeste. Em seguida, Uchoa vai chefiar a Segunda Divisão de Águas 
e Esgotos de São Paulo, onde possivelmente estabelece contatos com importantes engenheiros e políticos, como Victor Dubugras. Todavia, Flávio de Mendonça Uchoa interrompe essa atuação como engenheiro ao casar-se com Evangelina da Silva Prado, filha do conselheiro Antônio da Silva Prado, se mudando para Ribeirão Preto no intuito de assumir a direção da Fazenda Guatapará, que pertencia a Martinho da Silva Prado. Uchoa só irá voltar a atuar em trabalhos que envolvessem a engenharia urbana quando se torna procurador dos negócios da família na cidade de Ribeirão Preto.

Um pequeno trecho escrito por Afonso Arinos em 1905 transparece um pouco da simbologia de ter o engenheiro Flávio de Mendonça Uchoa como um integrante da família Prado:

Atravessamos, dentro de pouco, o Rio Mogi-Guaçu, por uma ponte magnificamente construida pelo empreiteiro deste trecho da Estrada, o engenheiro Flavio Uchoa, e logo desfilávamos em terras da Faženda de São Martinho, que começam a 14 quilômetros aquém da estação de Martinho Prado e terminam 22 quilômetros além. Todo este tracto de terra que margeia o Mogi-Guacu impressiona pela exuberância de suas matas. Ai notam-se ainda os vestígios da luta recente entre o bomem e a natureza bruta; a terra foi conquistada a pouco e não perdeu ainda o seu aspecto selvagem (Afonso Arinos em 1905 Apud ROSSINI \& OLIVEIRA: 1999: 24)

Flávio Uchoa irá, durante a Primeira República, se constituir como um empresário associado à modernização e implantação de infraestrutura na cidade, como no caso da criação da Cia. Eletro Metalúrgica de Ribeirão Preto, que se tornou nos anos 20 uma importante produtora de aço no Brasil. Mesmo antes, em 1905, Uchoa havia assumido as obras de calçamento e arborização da cidade, além da instalação de guias e passeios. Mais tarde, passa a ser diretor da Empresa Força e Luz de Ribeirão Preto, que havia sido adquirida por seu cunhado Plínio da Silva Prado.

A criação da Empresa de Força e Luz de Ribeirão Preto ainda se associava ao momento de abertura de capitais e criação de sociedades acionistas durante a Primeira República, sendo também o período de nascimento de diversas empresas municipais de serviços urbanos. Segundo Freire e Castro (2002), a União passou a dividir diversas atribuições político-administrativas com os governos estaduais, inclusive no que se refere aos recursos financeiros, possibilitando que as instituições políticos-administrativas brasileiras, tanto federais como municipais, se tornassem grande tomadoras de empréstimos. Essa foi a condição da consolidação da Empresa ao se capitalizar e absorver os contratos de serviços urbanos dos municípios da região.

Todavia, em 1926, a Empresa de Força e Luz de Ribeirão Preto é vendida ao grupo canadense-americano Eletric Bond \& Share para que Flávio Uchoa se capitalizasse para compra de equipamentos para Cia. Electro-Metalurgica. Porém, a falta de apoio financeiro e escassez de matéria-prima impugna esse projeto industrial no bojo da crise de 1929. Os serviços de águas e esgotos ainda permanecem sob a gestão de Uchoa até 1955, quando é rompido o contrato de concessão e a prefeitura passa a gerenciar o serviço.

Os mapas 7 e 8 demonstram, por fim, a mudança da cidade durante esse primeiro contexto de transformações urbanas recortado pela dissertação. Nas representações mapográficas se nota esse ciclo de mudanças realizadas durante a Primeira República, em que se insere a atuação da Empresa de Águas e Esgotos, posteriormente, Empresa de Força e Luz. Assim, se vê a alteração 
do antigo Patrimônio da Fábrica da Matriz, sem calçamento e eletrificação, com os rios ainda não retificados e as várzeas sem drenagem, para a cidade da década 1920, iluminada, com uma grande quantidade de edifícios eletrificados e conectados à rede de águas e esgotos. Os rios já retificados, com as avenidas de fundo de vale, e as várzeas drenadas formam o que seria a primeira perimetral da cidade. 

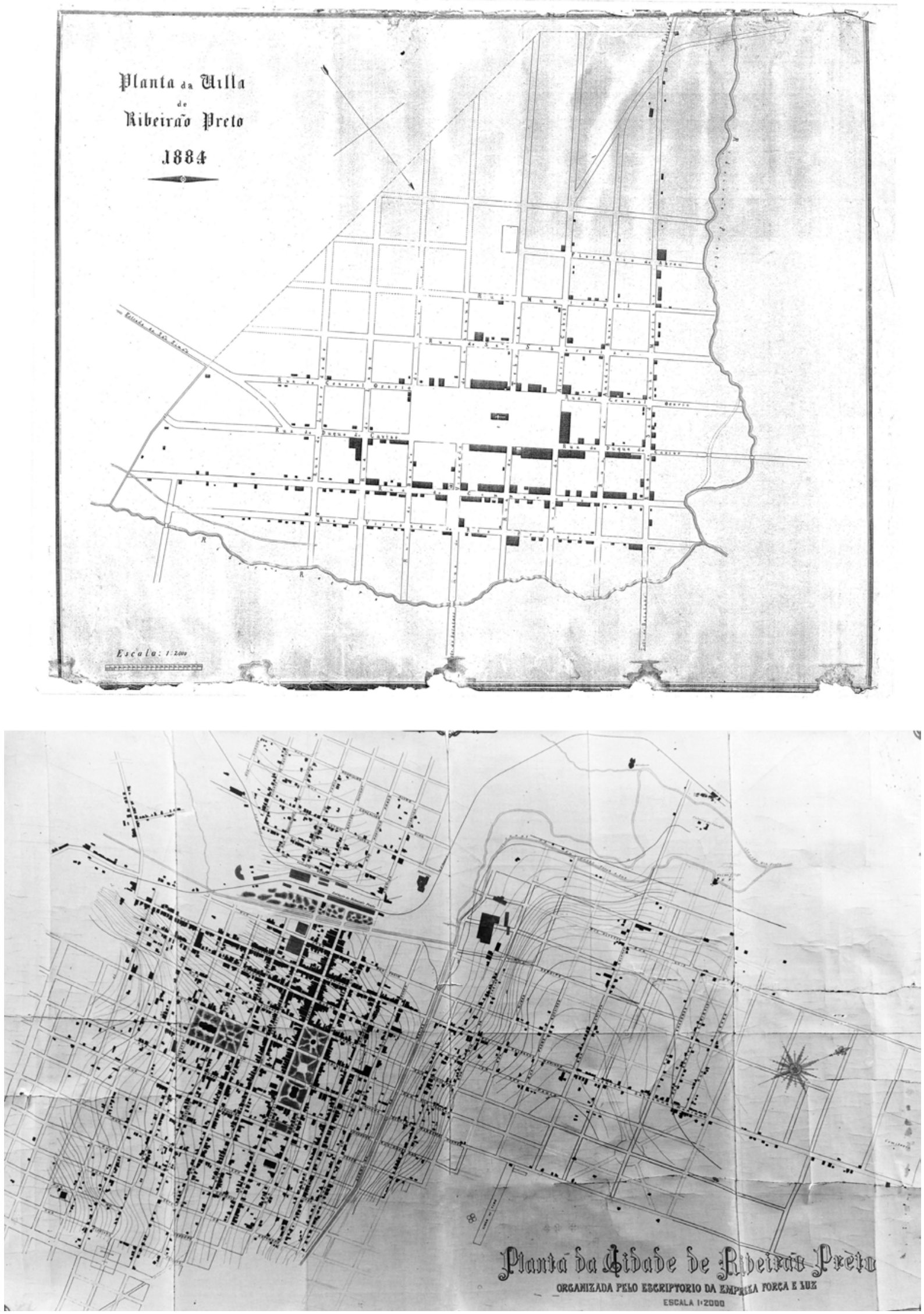

Mapas 7 e 8. Fonte: APHRP. 

Capítulo 3 



\subsection{O crescimento do arrabalde da capital d'oeste.}

As transformações econômicas, sociais e políticas ocorridas na região de Ribeirão Preto a partir da década de 1930 promoveram a perda da dianteira da economia agrícola, fazendo com que ao longo da década de 1940 se definisse uma subordinação à dinâmica industrial que se emanava da grande São Paulo. Um dos reflexos desse processo se torna visível no espaço central de Ribeirão Preto que se insere a partir de então num ciclo de verticalização e adensamento. Além disso o município irá se expandir com a criação de novos bairros acompanhando o aumento populacional.

A expansão do perímetro urbano de Ribeirão Preto se realiza pelo loteamento das glebas das fazendas que circundavam as fronteiras de seu antigo Patrimônio Religioso. Esse crescimento deslancha, principalmente, ao longo da primeira metade do século XX, quando a cidade recebe um enorme fluxo migratório em virtude de sua posição privilegiada na economia de exportação do café. Como aponta Garcia (2013), apesar da existência de um precoce mercado de terras urbanas - , realizado através do acúmulo de terrenos dentro do Patrimônio Religioso vendidos pelos foreiros - só durante a Primeira República, sob a gestão dos Intendentes Municipais, é que se inicia a repartição das glebas periféricas para transformá-las em loteamentos de ocupação urbana.

Segundo Garcia (2013) a primeira medida urbanizadora da Câmara Municipal, ainda ao final do século XIX, teria se realizado em torno da retificação do Ribeirão Preto e da construção de seu traçado viário. De modo que a instalação do prédio da Estação Ferroviária determina, a partir de 1885, esse eixo de expansão do núcleo urbano em direção às planícies do vale do ribeirão Preto que ainda possuía do outro lado de suas margens grande disponibilidade de glebas para serem loteadas. Como o domínio sobre o solo dessa região estava livre da autoridade da Fábrica Paroquial, instituição que exercia o controle sobre os terrenos do patrimônio eclesiástico, o loteamento das glebas do perímetro urbano vai progressivamente se tornando um negócio para os especuladores de terras.

No final do século XIX se apresenta no Brasil uma tendência cada vez mais latente de crescimento das cidades:

Nos fundos documentais públicos e, especialmente, nos municipais que tinham a ver diretamente com a terra urbana, desponta o termo "loteamento" mais para o fim do século XIX e se torna corriqueiro no inicio do atual.(MARX: 1991::108) 


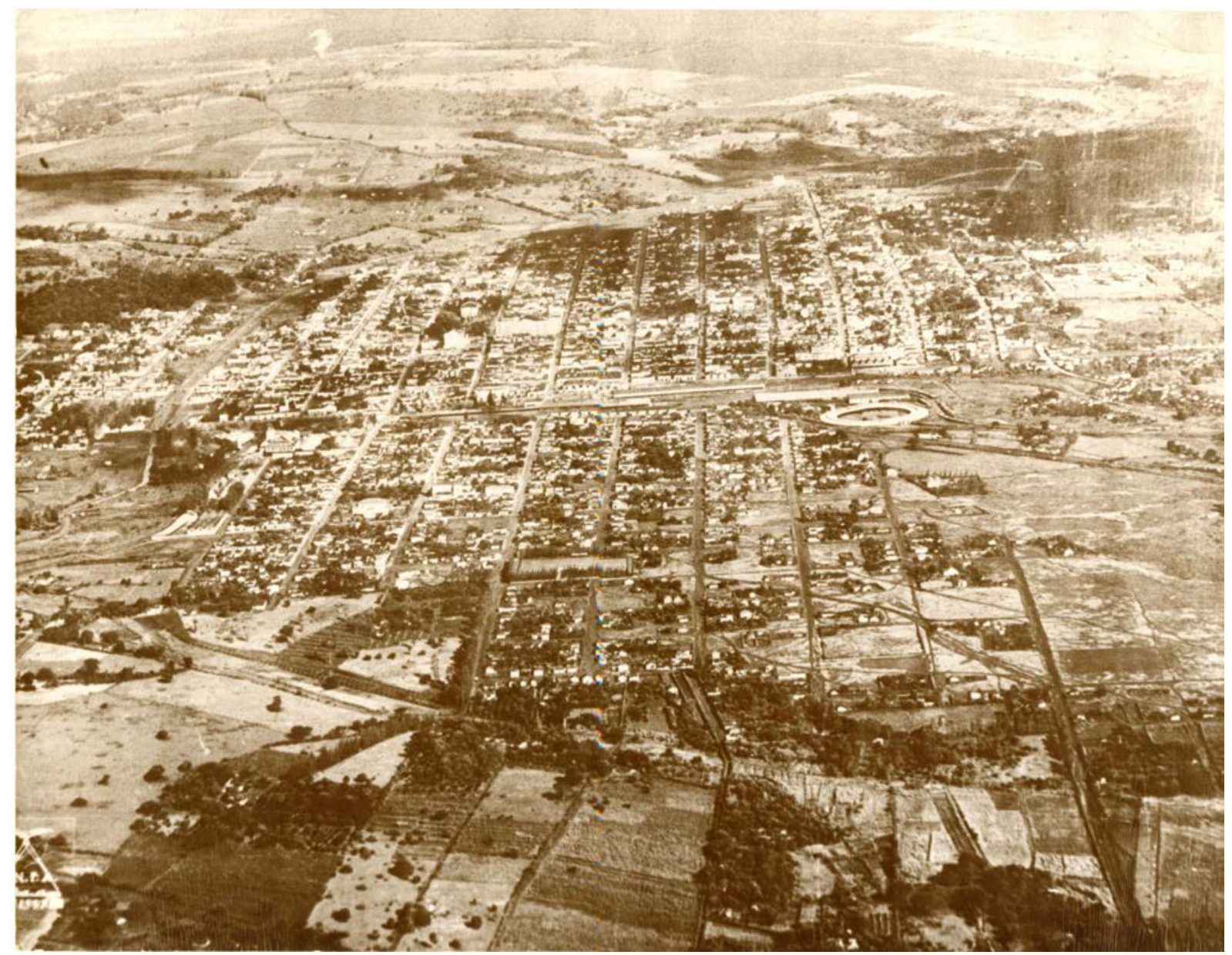

Figura 22: Uma fotografia área da cidade de Ribeirão Preto na década de 1930. Em primeiro plano se vê a Vila Tibério, um dos primeiros loteamento a expandir a retícula do centro da cidade. $\mathrm{Na}$ imagem é possível perceber como as glebas da área sul no canto direito da fotografia se encontravam numa posição mais elevada em relação a cidade, além de ainda se encontrar nos anos 30 pouco ocupada. Assim, essa região se tornará ideal para abrigar os loteamentos da classe alta durante a década de 1940. Fonte: APHRP.

Este é o período da formação e desenvolvimento dos primeiros bairros em Ribeirão Preto que extrapolaram os limites do Patrimônio da Fábrica. Valéria Valadão (1997) aponta que, a partir das duas últimas décadas do século XIX, o núcleo urbano não se suporta mais apenas nos limites do centro $^{37} \mathrm{e}$, em meio às novas demandas por habitação com o crescimento demográfico da cidade, o mercado imobiliário torna-se uma melhor opção para girar e acumular capital em detrimento da imobilização do solo pelas fazendas agrícolas:

Assinalou o ano de 1900 (...) o inicio do periodo dos especuladores. Da especulação participavam os fazendeiros, seja comprando grilos, seja vendendo suas próprias terras (...). Era preferivel lotear um dominio, cujos titulos não ofereciam plena garantia ou que sempre estava exposto ao ataque de um audacioso falsário (MONBEIG, 1984, p.146).

Bacellar (1999) demonstra que, durante o ciclo cafeeiro, o progressivo aumento das safras gerando a desvalorização do preço do café teve um reflexo direto no mercado de terras de Ribeirão Preto. Após a euforia dos primeiros anos da República, os valores pagos pela terra caem e, apesar

37 A área que nos anos 30 será definida pelo perímetro circunscrito pelas avenidas Jerônimo Gonçalves; Francisco Junqueira; Independência e Nove de Julho. 
de ligeiras recuperações circunstanciais, se mantêm numa tendência de declínio ao longo das crises desse período. Essas flutuações do preço da terra geraram as brechas para a atuação de especuladores imobiliários na ocasião da instauração de processos sucessórios com a morte de chefes familiares proprietários de terras. A hora da repartição das heranças se constituirá no momento ideal para incorporação de propriedades pelos loteadores de glebas do perímetro urbano.

Para ilustrar esse movimento, Bacellar (1999) cita a atuação do futuro loteador do bairro Vila Tibério, que constitui sua gleba em duas etapas distintas, entre 1882 e 1897, sempre adquirindo terras de dois filhos e três netos de Luiz Antônio de Sousa Diniz, então proprietário da fazenda Bananal. Tibério Augusto Garcia de Sene, antes de fundar o bairro, ainda incorpora terras da vizinha fazenda Sertãozinho, reunindo, ao final do século XIX, uma enorme reserva de terra nos limites do núcleo urbano num período em que os loteamentos ainda eram uma tímida opção de negócio.

José Teodoro da Costa, por exemplo, adquiriu um lote da fazenda Tamanduá no ano de 1890, pagando 3:000\$000. Cinco anos mais tarde, vendeu-o por 20:000\$000, numa impressionante valorização. Em caso semelhante, José Evangelista da Silva adquiriu dois quinhões no ano de 1879, avaliados respectivamente em 550\$000 e 690\$000 e revendeu-0s, juntos, por 3:000\$000 em 1881. $O$ pequeno intervalo entre estas compras e vendas e a valorização obtida permite supor que a terra adquirida veio a receber melhorias, provavelmente o plantio de cafezais ou, pelo menos, a derrubada de matas. O interessante é que tanto José Teodoro da Costa quanto João Evangelista da Silva não se tornaram conhecidos enquanto cafeicultores, confirmando que atuavam enquanto autênticos formadores de fazendas, personagens bastante citados na bibliografia (BACELLAR: 1999: 114)

Esse mercado de terras que precede a expansão propriamente urbana é realizado por figuras marginais ao grande ciclo agroexportador de café. Algo que irá perdurar na medida do desenvolvimento urbano, pois não se encontram os grandes fazendeiros nessas transações miúdas de terras do perímetro do Patrimônio da Fábrica da Matriz. A expansão da cidade de Ribeirão Preto se associa, dessa maneira, à economia cafeeira, principalmente, após a instalação na cidade da ferrovia da Cia. Mogiana, em 1885, quando se assiste a uma explosão demográfica e a população triplica durante a década de 1890.

Esse fenômeno cria as condições necessárias para se extrair renda da terra por meio da transformação das fazendas ou terrenos nacionais em loteamentos imobiliários. Nesse início, a expansão se dá através de dois tipos: os loteamentos oficiais e os particulares. Ou seja, antes dos especuladores, uma primeira ocupação da periferia ocorre com um loteamento oficial implantado

Alta Mojiana: população total - 1874-1934 (BACELAR: 1998:153)

\begin{tabular}{lrrrrr}
\hline Município & $\mathbf{1 8 7 4}$ & $\mathbf{1 8 8 6}$ & $\mathbf{1 9 0 0}$ & $\mathbf{1 9 2 0}$ & $\mathbf{1 9 3 4}$ \\
\hline Batatais & 13.464 & 19.915 & 19.164 & 21.816 & 24.772 \\
Franca & 21.419 & 10.040 & 15.491 & 44.308 & 60.237 \\
Ribeirão Preto & 5.552 & 10.420 & 59.195 & 68.838 & 81.565 \\
Sertãozinho & - & - & 10.940 & 30.522 & 31.039 \\
Estado de SP & - & 1.221 .380 & 2.279 .608 & 4.592 .188 & 6.450 .931 \\
\hline
\end{tabular}


nas terras devolutas do entorno do núcleo urbano, um empreendimento que possuía o objetivo de assentar colonos europeus como parte da política imperial de imigração. No Brasil foram criadas 14 colônias pelo Governo Imperial, entre 1827 a 1889. Em Ribeirão Preto, o "Núcleo Colonial Senador Antônio Prado", integra essa política sendo um projeto do patriarca Antônio Prado na região em que os integrantes de sua família vinham adquirindo terras e construindo fazendas.

A elaboração do projeto da Colônia se inicia, em 1886, após a instalação definitiva da estação da Cia. Mogiana e, também, da realização do mapeamento dos “Terrenos Nacionais" da Vila de São Sebastião de Ribeirão Preto. Em 1887, a área do núcleo começa a ser retalhada em lotes, sendo que, no ano seguinte, no momento da inauguração do "Núcleo Colonial Antônio Prado", os lotes passam a ser vendidos a 1.250 francos. Essa organização em lotes rurais serve de início ao abastecimento de alimentos à cidade, que em meio à monocultura do café se tornam as únicas terras disponibilizadas à agricultura alimentar. A sua subsequente ocupação urbana com a instalação do Cemitério da Saudade e o prolongamento de ruas centrais até os seus terrenos faz com que essa inserção na malha urbana incentive os sitiantes à subdivisão de suas propriedades em quadras e lotes destinados à venda.

Da colônia de imigrantes se originariam, principalmente, os bairros do Barracão e dos Campos Elíseos como uns dos mais populosos da cidade. ${ }^{38} \mathrm{O}$ nome do bairro Barracão advinha do antigo edifício de hospedaria dos imigrantes que chegavam a Ribeirão Preto para assumirem os seus lotes na colônia. Ao longo do século XX, com a fusão do bairro Barracão a um loteamento realizado por uma indústria de refrigerantes chamada Ipiranga, em 1953, essa região se tornará uma das mais populosas chegando a possuir na década de 1990 por volta de 150 mil habitantes. Outra parte deste grande arrabalde recebeu o nome de Campos Elíseos, que receberia no futuro as indústrias de linhas e tecidos da família Matarazzo, o que fez com que a sua população aumentasse a quase 60 mil habitantes. Essa região recebe as instalações de diversas fábricas, sendo esse tipo de ocupação o que dita a valorização de suas propriedades e terrenos que possuíam grandes faixas de terras legadas pelo desenho do antigo Núcleo Colonial, terrenos ideais, portanto, para implantação das indústrias.

O segundo tipo de expansão - os loteamentos particulares - surgem em Ribeirão Preto na medida do interesse de cada proprietário de antigas chácaras, sítios e fazendas pelo melhor rendimento monetário através da venda da terra do perímetro urbano. O retalhamento das propriedades rurais, seguindo, na maioria das vezes, o sistema ortogonal de ruas e lotes, com a reprodução do traçado do centro da cidade, leva à proeminência econômica dos loteamentos como empreendimentos voltados à acumulação de capital:

O loteamento passava a ser um grande negócio. Tal prática deu inicio ao processo de especulação sobre o valor do solo urbano nas transaçôes de compra e venda e ainda possibilitou de forma fácil a aquisição de riquezas pelos seus agentes - os loteadores (VALAD $\tilde{A O}, 1997$, p.58)

38 Para um aprofundamento da história desses bairros ver SILVA, A. C. da. Expansão urbana e formação dos territórios de pobreza em Ribeirão Preto: os bairros surgidos a partir do Núcleo Colonial Antônio Prado (1887). São Carlos: UFSCar, 2008. 


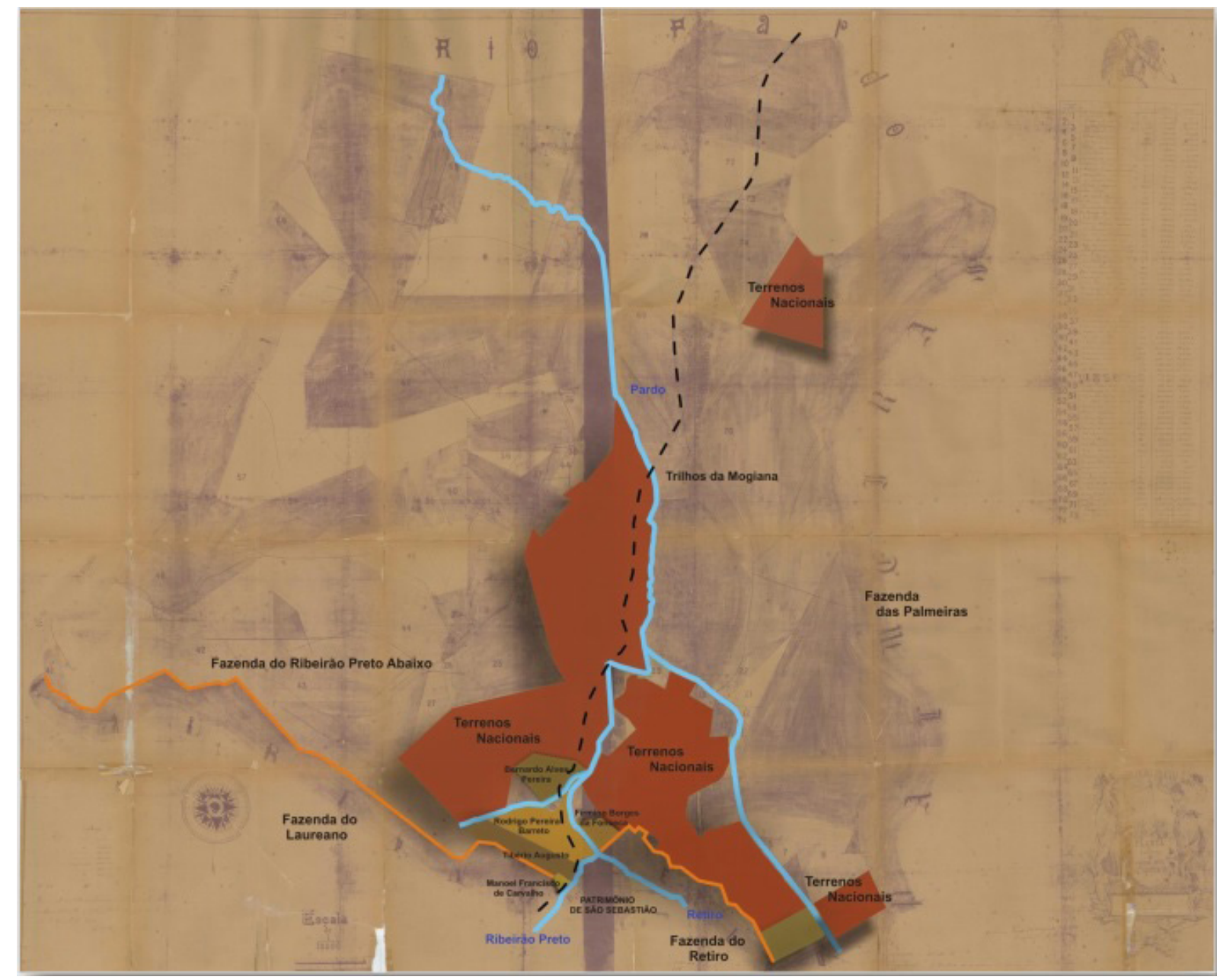

Mapa 9: As glebas da Fazenda do Ribeirão Preto Abaixo, sendo o território a montante do ribeirão Preto, numa região mais baixa onde foi implantado o Núcleo Colonial. Fonte: Garcia: 2013: 300.

Os dois bairros mais antigos da cidade ainda se encaixam de maneira incipiente nessa lógica dos loteamentos enquanto empreendimentos imobiliários. O bairro República, o primeiro a expandir o núcleo urbano da Fábrica da Matriz, foi ocupado praticamente de forma espontânea pelas turmas de trabalhadores da instalação da primitiva estação da Cia. Mogiana. Ele se localizava na parte baixa da cidade e, posteriormente, se uniria aos bairros Vila Virginia e Vila Tibério. O segundo bairro mais antigo de Ribeirão Preto, Santa Cruz, foi implantado na mesma década de 1890, quando José Theodoro Jacques adquire algumas glebas de terras da Fazenda do Retiro, no caminho para São Simão, e, após a formação de sua chácara e de uma olaria, ergue a Capela em devoção a São João Batista. Após José Jacques realizar uma doação de terras aos seus colonos, eles passariam a construir ao redor da chácara as suas residências até que, em 1892, com a doação da capela do bairro à Igreja Católica, as autoridades eclesiásticas demarcam essa região como o largo de Santa Cruz do José Jacques.

A Vila Tibério, um dos bairros mais tradicionais da cidade, também surge ainda ao final do século XIX, quando o latifundiário João Franco de Moraes Otavio reparte suas terras entre seus herdeiros, e Tibério Augusto Garcia de Senna, genro do latifundiário, adquire com capital próprio outra porção de terra confinante aos limites do Patrimônio Religioso. Tibério Augusto, valendo-se 
de sua profissão de agrimensor, inaugura o loteamento vendendo os terrenos no valor de 50 mil réis. Entretanto, logo o crescimento da cidade o permite vender os lotes a 200 mil reis através do parcelamento de hipotecas em 10 ou 12 anos.

Essa valorização da Vila Tibério ocorre, principalmente, em virtude de sua proximidade com o centro e a Estação Mogiana. O bairro também é ocupado pelos funcionários da ferrovia e imigrantes italianos que abandonam a lavoura de café em busca de trabalhos mais atrativos na cidade. Muitos destes imigrantes irão se tornar os operários das indústrias de bebidas instaladas na Avenida Jerônimo Gonçalves, como a Cia. Cervejaria Antártica (1911) e a Cia. Cervejaria Paulista (1914), o que irá caracterizar a Vila Tibério como um bairro operário desde a década de 1910.

Apesar de ser um dos bairros mais antigos da cidade, o desenvolvimento da Vila Tibério acontecerá, principalmente, após a década de 1960, quando as linhas dos trens da Cia. Mogiana são deslocadas para a periferia da cidade e a população do bairro cresce até atingir por volta de 60 mil habitantes na década de 1990. Os trilhos da ferrovia estabeleciam uma fronteira física entre a Vila Tibério e o centro de Ribeirão Preto que vinha atravessando um processo de modernização mais acentuado. O memorialista Rubem Cione (1997) aponta o seguinte sobre a Vila Tibério:

\section{A VILA HOSPEDOU OS IMPERADORES}

Antigos moradores de Vila Tibério, comoo motorista Socura, não esquecem a história ligada ao prédio da Fundação Antonio e Helena Zerrener. Armando Scoura dir. que naquele casarão, exatamente nos dias 25 e 26 de novembro de 1880, Eduardo Prado e Martinico Prado, hospedaram Dom Pedro II e senhora. O Imperador e Imperetriz passaram por Ribeirão Preto rumo a Franca, onde foram a "fim de entregar o título de barão de Franca a um dos grandes cafeicultores da região, assim como o coronel Francisco Schmidt em Ribeirão Preto. (CIONE: 1997: 555)

Nos anos de 1920, numa região contígua à Vila Tibério, encostada no antigo bairro da República, em meio às chácaras, Álvaro Lima irá negociar com Lindolfo Nogueira a compra da Chácara Paraíso por 50 mil reis. Cinco anos depois, com a aprovação do projeto na Prefeitura Municipal, ele abre o loteamento seguindo o mesmo padrão de traçados anteriores por ser o método mais fácil e menos oneroso. Além do início da venda dos lotes, Álvaro Lima faz doações de áreas para a implantação de escolas e igrejas no bairro, reivindicando também a ampliação da rede de água e esgoto que, entretanto, demorará a chegar à região. A incorporação dos quarteirões do antigo bairro da República consolida a Vila Virginia também como um bairro de operários e imigrantes destacados da lavoura nas primeiras décadas do século XX.

Sobre a transação, o memorialista Cione (1997) escreve o seguinte:

Havia falecido naquela parte da localidade, região baldia e que então se afigurava distante e pouco atraente, o sr. Lindolfo Faria Nogueira, deixando como bem imóvel, uma área de doze alqueires de terra inculta, propriedade que adquirira muitos anos passados, a preço infimo, segundo os padrões do tempo. As terras, processadas a herança, foram a praça em agosto de 1923, verificando-se uma proposta para aquisição de oito alqueires, por parte do sr. Álvaro Lima, cidadão ativo e esclarecido, que teve a visão do valor futuro da localidade. E a gleba foi arrematada, à falta de mais licitantes, pela importância de quarenta e cinco cruzeiros novos ...

$O$ adquirente, homem de negócios que para negócio fez. a aquisição em foco, loteou a metade das terras, obtendo com isso, cento e oitenta lotes que foram vendidos em pouco tempo, mercê de boa propaganda, de par com o espirito progressista do povo. As construções, dentro em pouco, foram surgindo, marcando a região com a presença fixa do homem em seus lares (CIONE: 1997: 562) 
Álvaro Lima havia comprado as terras com capital que adquirira através de sua profissão de caixeiro viajante, o nome da Vila de Virginia era uma homenagem a sua esposa que teria a iniciativa da fundação de um grupo escolar no bairro, além de propor a doação do terreno para construção da Igreja Santa Maria Goreti, como havia solicitado o Bispo D. Luis do Amaral Mousinho. A construção do asfaltamento do bairro, além da conexão as redes de energia elétrica e de água e esgoto dependeriam dos inúmeros encaminhamentos dessas demandas pelo loteador Álvaro de Lima.

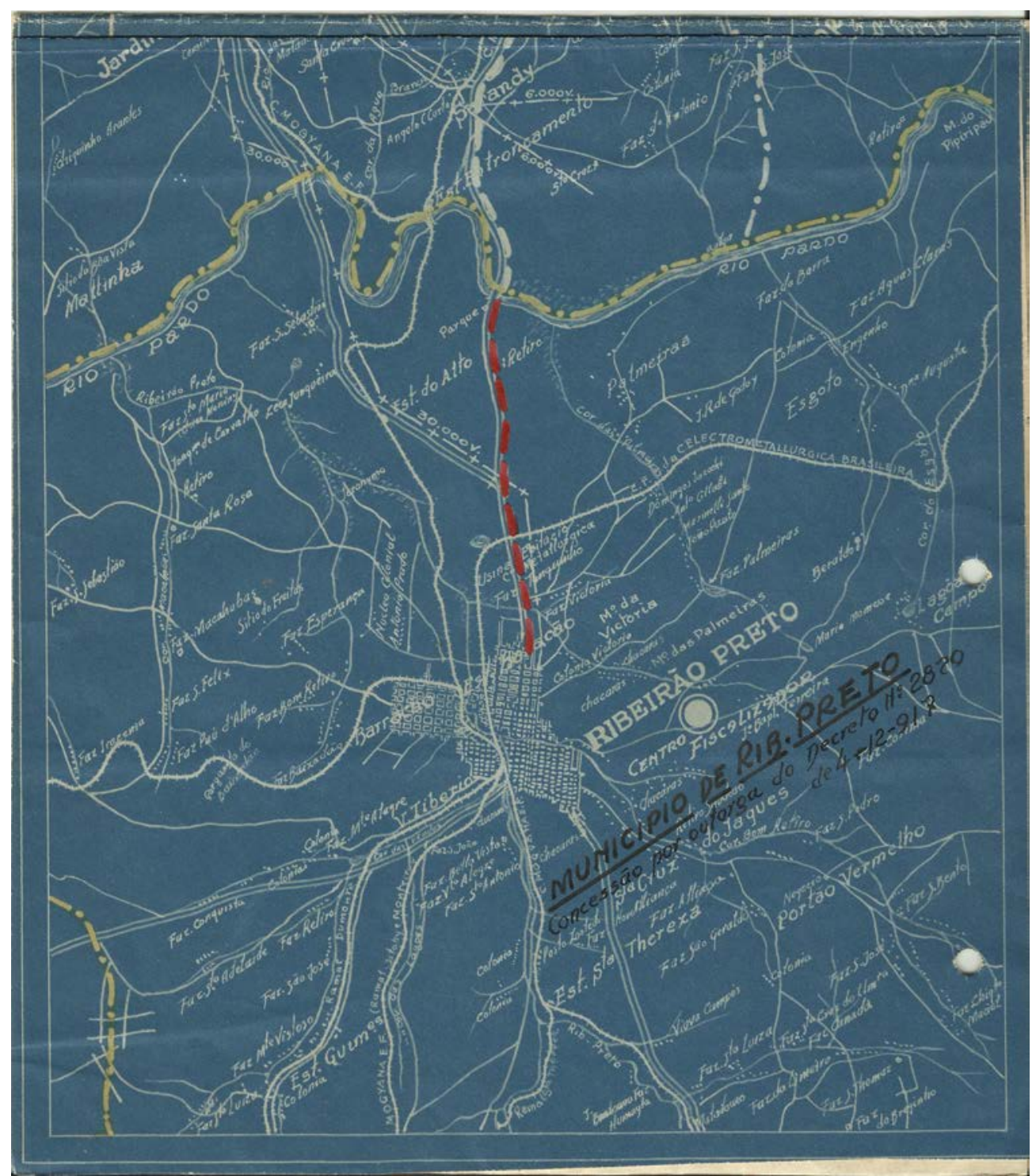

Mapa 10: As fazendas do perímetro urbano de Ribeirão Preto. Fonte: APHRP.

Karla Sanches (2003) aponta que a década de 1920 é um período em que a terra será bastante parcelada pela venda de terrenos em lotes. A atuação da Comissão de Obras no reconhecimento do retalhamento das áreas confirma o crescimento da cidade, tanto pela autorização da construção de bairros além do perímetro dos córregos centrais, quanto pela aprovação da abertura de ruas e avenidas. A construção de novos loteamentos de vilas e casas operárias é realizada, principalmente, pela iniciativa privada, que era incentivada pela Câmara Municipal através da isenção do Imposto 
Predial. Essa atuação liberal da Comissão de Obras Públicas através das isenções confirma o surgimento da figura do loteador, ou seja, um empreendedor que irá retalhar glebas de terra para vender suas parcelas desenhando a cidade.

No ano de 1924, a Lei Municipal no 302 definirá no seu Art. $2^{\circ}$ o seguinte:

Os proprietários de terrenos anexos ao perímetro urbano, que pretenderem dividi-lo em lotes abrindo a sua custa ruas e praşas para formarem vilas e povoaçöes, deverão sujeitar as respectivas plantas e planos a aprovação da Câmara, cedendo a está os terrenos a serem ocupados pelas ruas e praças (...). Aprovadas a planta e a proposta mediante parecer do engenheiro municipal, a Câmara autorizará o prefeito a conceder a licença, uma vez observada às posturas e regulamentos municipais, e a aceitar a doação dos terrenos necessários para ruas e praças que forem abertas à custa dos mesmos proprietários. A Câmara não aprovará projetos de formação de vilas ou povoações quando se tratar de terrenos situados a mais de $300 \mathrm{~m}$ dos limites extremos do perímetro urbano. $\left(3^{\circ}\right.$ Livro de Registro de Leis de Ribeirão Preto: Lei 302, p.1 apud SANCHES: 2003:180)

No relatório do prefeito municipal referente ao exercício de 1923, se vê num tom bastante ufanista o crescimento urbano da cidade:

É com máxima satisfacção que podemos confirmar neste relatório os lisonjeiros prognósticos que se vem realizando, de anno para anno, com relação ao progressivo desenvolvimento de Ribeirão Preto, facto este que tem consolidado, cada vez mais, a confiança geral no futuro incontestável desta região.

Um dos factos demonstrativos desse progresso da cidade verifica-se no crescente numero de prédios novos e novos edifícios de architectura moderna, que tem sido construidos na zona urbana e suburbana. Dos 434 requerimentos que passaram pela Portaria Municipal, 253 eram relativos a construcões, augmentos e reformas de prédios, tendo sido approvadas pela repartição de obras 237 plantas, sendo 190 para construçooes novas e 47 para reformas de prédios (...) a repartição de obras verificon a existência de 3906 predios em 1923, tendo havido um angmento de 172 predios sobre o numero existente no ano anterior, ou seja uma media de cerca de 15 prédios por mez. em 1923 (GULÃO: 1923: 3)

A construção de quinze edifícios por mês em Ribeirão Preto chega à média de crescimento de 180 construções por ano, algo que não equivalia à aterradora taxa de crescimento da cidade de São Paulo, que, segundo Saturnino de Brito, chegava à média de três mil construções por ano, todavia, Ribeirão Preto já com 60 mil habitantes, crescia a passos largos. É importante notar as referências às construções suburbanas que, cada vez mais, aprecem nos relatórios dos Intendentes Municipais. O controle da quantidade de edificações da cidade se fazia em virtude do lançamento do Imposto Predial, uma das maiores fontes de receita municipal junto aos empréstimos contraídos pela Câmara, o que dava suporte financeiro para obras de melhoramentos urbanos como praças, ruas e calçadas.

Seguindo a antiga tônica de crescimento fragmentado do município, que desde o final do século XIX vinha privilegiando a área central, se vê nos relatórios uma associação entre os poderes públicos e particulares nesse processo de expansão urbana, o que promove mudanças de uso e aparência do entorno da Praça XV de Novembro que iria abrigar as sedes de bancos:

Ao lado da ação dos poderes municipaes, a iniciativa particular também veem applicando seus capitais na construção de prédios de residência, na fundação de bons edifícios destinados a sede de associaçoes importantes, de caráter commercial ou industrial, e em auxilios efficientes de assistência. É digno de registro o exemplo dado pelos Bancos da Capital, que dotaram suas agencias locaes de confortáveis e elegantes edificios, que honram a cidade. Ao lado do belllo sobrado, anteriormente construído pelo "Banco Francez e Italiano pela America do Sul", onde funcciona a sua agencia, foi inangurado em princípios de novembro o lindo edifício da agencia do "Banco do Commercio e Industria de S. Paulo. 
Igualmente o "Banco do Brasil" e o "Banco de S. Paulo" estão a concluir as construções destinadas as suas respectivas agencias, correndo desta forma para dotarem a cidade de importantes edifícios, que attestam a confiança desses conceituados estabelecimentos de crédito no incremento progressivo deste rico Município (GULÃO: 1923: 5)

Nesse sentido, na linha dos autores como Faria (2003) e Silva (2007), as obras de saneamento e embelezamento realizadas durante a Primeira República consolidaram uma divisão social no município, assim, se vê a expansão imobiliária agravar essa divisão urbana entre o norte - região baixa na vertente do rio Preto historicamente constituída como território da pobreza - e o sul região alta privilegiada pelo urbanismo sanitarista e, posteriormente, pelos bairros mais ricos.

Morar além da linha férrea que cortava a cidade no limite noroeste do centro - antigo Patrimônio da Fábrica da Matriz - significava se destinar ao setor pobre de Ribeirão Preto. A população o fazia em virtude de não encontrar residências na vertente valorizada. A cidade fica dividida em dois setores - rico e pobre - relativamente ao eixo ferroviário. Entretanto, somente na década de 1940 a população mais rica consolida sua locomoção do centro da cidade e a malha urbana se expande para o sul com a abertura de novos loteamentos. 


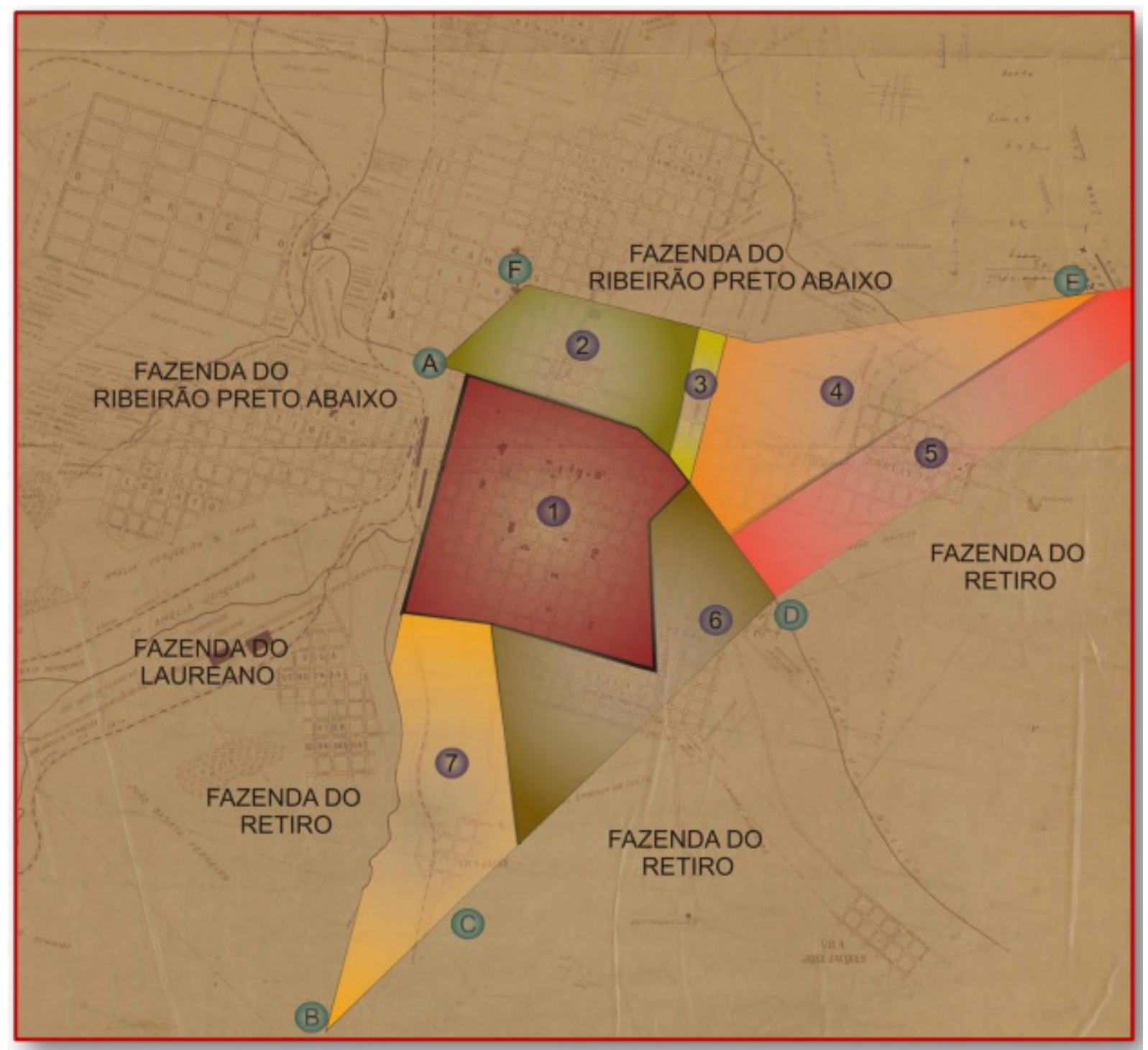

Mapa 11: reelaborado por Garcia (2013) a partir dos desenhos de Osmani Emboaba da Costa, os recortes representados sobre uma planta da cidade de 1943 demonstram a divisão judicial da Fazenda Barra do Retiro. Nela é possível enxergar o traçado dos loteamentos sobrepondo as terras das antigas fazendas. A ocupação urbana da zona norte da cidade se expande, portanto, sobre os terrenos da Fazenda do Ribeirão Preto Abaixo, já a zona sul sobre a Fazenda do Retiro, com os loteamentos da década de 40 ocupando os recortes 6 e 7. Contudo, nesse período essa região já está bastante repartida em virtude da atuação dos compradores de terras do perímetro urbano. Fonte: GARCIA: 2013: 80

\subsection{A ocupaçáo da parte alta da cidade.}

Ao longo da Primeira República a parte mais alta da cidade havia recebido de forma privilegiada as obras de melhoramentos e embelezamentos sanitários que reforçaram a divisão urbana entre os vetores sul e norte. A década de 1930, todavia, marca a entrada de novos grupos comerciais e industriais no mercado imobiliário e, entre 1920 e 1940, progressivamente, se assiste ao deslocamento das residências mais abastadas para o sul da cidade, numa região mais alta, contígua ao centro. $\mathrm{O}$ antigo Largo da Matriz é atingido por um processo de verticalização com a mudança de função dos edifícios de seu entorno para um perfil mais comercial ou de lazer. Um caso emblemático é o da esquina da rua General Osório com a Alvares Cabral que será ocupada pelo edifício Diederichsen. 


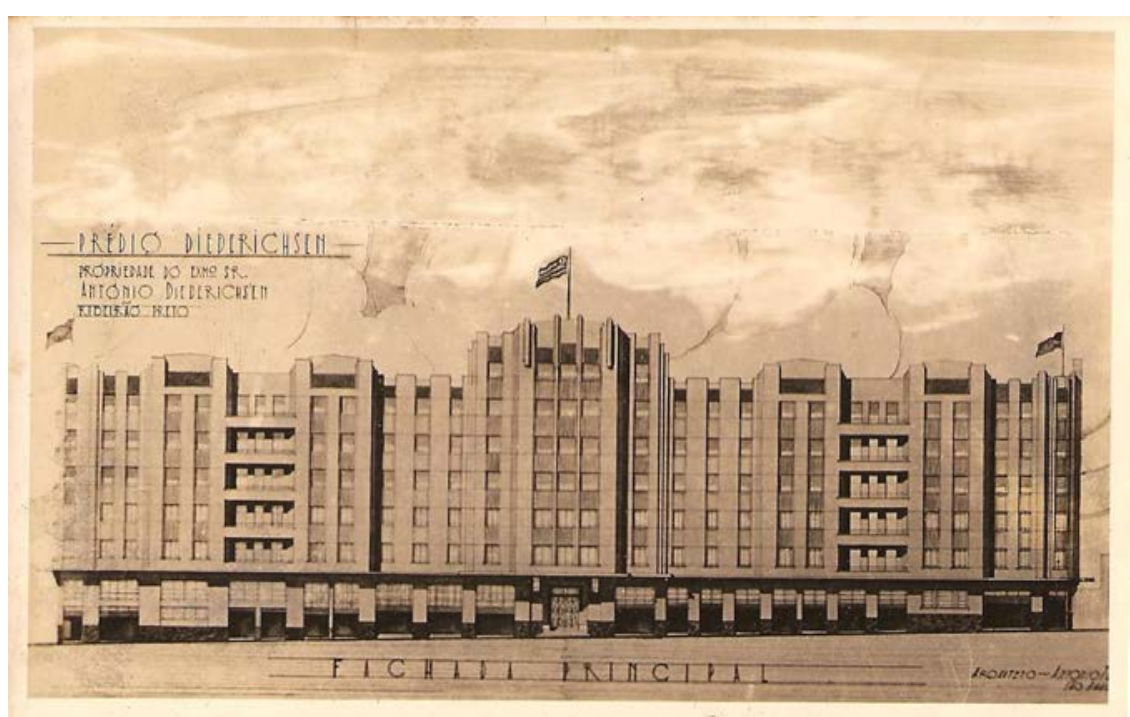

Figura 23: Fachada principal do edifício que abrange toda lateral do quarteirão entre as ruas General Osório e São Sebastião. O prédio é erguido no terreno do antigo casarão de Joaquim Diniz da Cunha Junqueira, sendo implantado num tipo lote republicano, ou seja, uma faixa de terreno estreito e alongado. Fonte: APHRP.

A construção desse edifício na década de 1930 localiza-se justamente na transição da Primeira República para a Era Vargas, período marcado pelo declínio da economia cafeeira e o desenvolvimento de uma maior pujança urbano-industrial. O prédio é erguido no lote até então ocupado pelo casarão do coronel Joaquim da Cunha Diniz Junqueira, e substituiria, dessa maneira, a casa feita nos moldes dos Códigos de Posturas republicanos, que era utilizada pelo influente político para articular seus interesses no Diretório Municipal do PRP. O Edifício simbolizando o início do apagamento de um imaginário político republicano e o nascimento de uma mentalidade mais próximo ao populismo urbano da política varguista.

Erguido em concreto armado, o prédio seria inaugurado, em 1938, sendo mais alto da cidade, com seis pavimentos distribuídos segundo a adoção de um programa moderno de diferentes usos. Ele será ocupado, principalmente, por apartamentos de classe média, além de salas comerciais e, ainda, por um cinema e um hotel. O prédio representa o início da verticalização do centro, que deixará de ser o cenário de palacetes e sobrados ao redor do jardim fracês da Praça XV Novembro para se tornar um lugar de passagem de diferentes classes sociais, como o núcleo comercial de uma cidade maior e mais fragmentada.

Karla Sanches (2003) também apresenta o construtor do edifício, Antônio Diederichsen, como uma figura emblemática do desenvolvimento urbano-industrial de Ribeirão Preto. Diederichsen, mesmo enquanto produtor de café, também se associa aos negócios urbanos da agroexportação. Faz isso ao arrematar, em sociedade com João Hibbeln, o Banco Construtor de Santos, abrindo uma sede em Ribeirão Preto com o nome Diederichsen \& Hibbeln. Além do Banco, junto a sua serralheria, Diederichsen irá explorar os ramos de implementos agrícolas. Durante a crise cafeeira, adquire o terreno do antigo casarão de Diniz Junqueira e, em 1934, inicia a construção do edifício entrando no ramo da construção civil. Segundo Valadão (1998), o projeto de Antonio Terreri e Paschoal Vicenzo se destaca na cidade pelo seu programa inovador de distribuição dos seis pavimentos com um bar e onze lojas. Para revestir trechos da estrutura de concreto armado no 


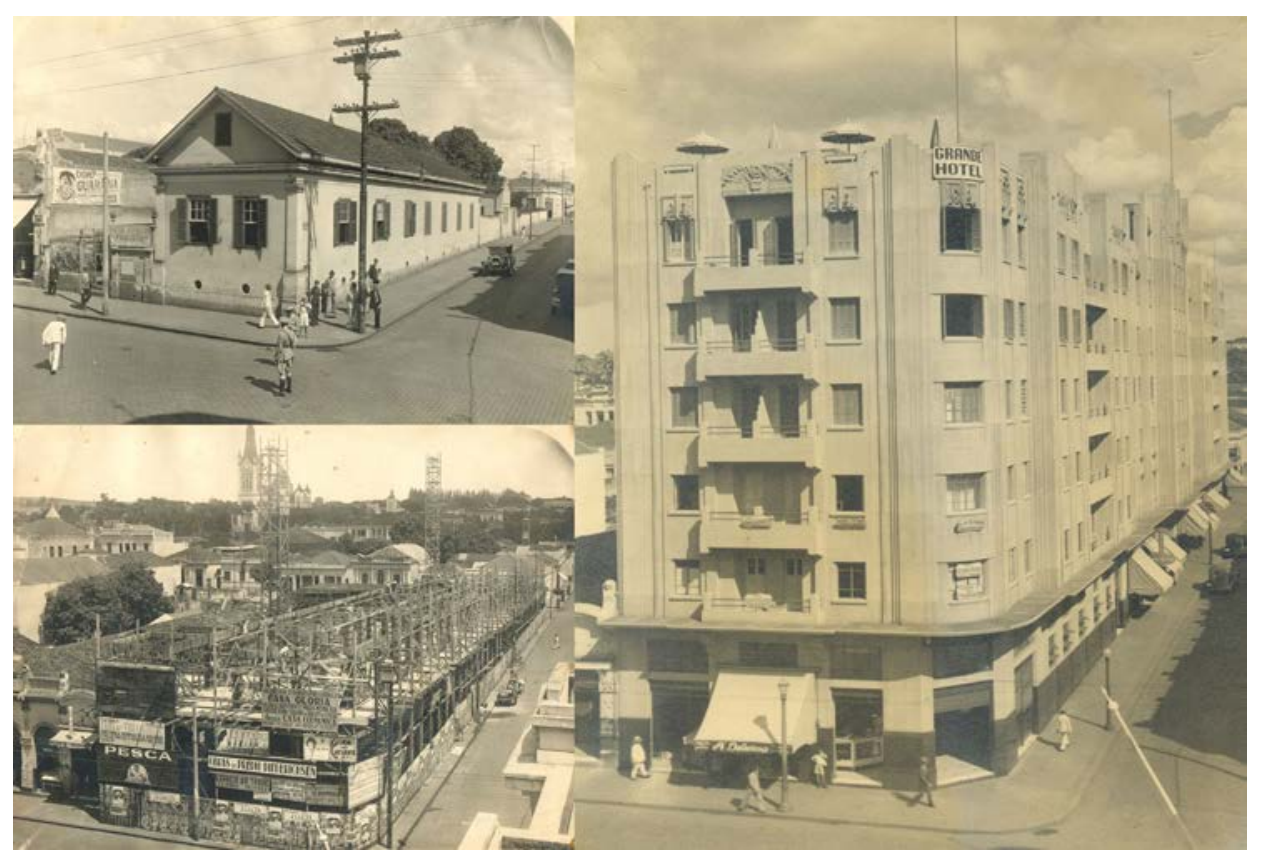

Figuras 24, 25 e 26: imagens emblemáticas da transformação do centro da cidade. Primeiro a residência do Cel. Quinzinho da Cunha Junqueira, localizada na Rua General Osório esquina com Rua Álvares Cabral, local de diversas reuniões do diretório municipal do PRP durante a Primeira República. Em seguida a construção do Edifício Diederichsen ao longo da década de 1930 quando o centro da cidade começa a mudar de função e ocupação. Por fim, o edifício pronto, em 1938, substituindo o antigo casarão e mesclando em seu programa apartamentos de classe média com espaços comerciais e de lazer.

térreo, é realizado um borrado de dois metros de mármore preto.

Apesar de Ribeirão Preto não se constituir nesse momento como uma grande cidade ela atravessa um processo semelhante ao descrito por Feldman (2005) em São Paulo. Durante a década de 1940 a cidade é atingida por um boom imobiliário que provoca mudanças na sua constituição espacial, principalmente através da intensificação da verticalização de áreas centrais e da expansão periférica. Isso occorre tanto como estratégia de moradia da população de baixa renda, quanto como uma tentativa das elites estabelecerem regiões de vizinhança homogênea exclusivamente residenciais.

Além da consolidação do modelo bairro jardim, os anos de 1940 são marcados por mudanças significativas no processo de verticalização em São Paulo. Antes de mais nada, destaca-se o fato da mudança na forma de produção dos edifícios. Souza (1994:98) define o ano de 1947 como do início da incorporaşão de edifícios em São Paulo, quando passam a ser produzidos para venda, em função das desvantagens colocadas para a produção de imóveis para aluguel pela Lei do Inquilinato em 1942. Uma outra mudança, segundo Somekh (1987:85) é o fato da verticalização residencial extrapolar a área central e inverter a predominância de edificios de uso terciário restritas ao centro. Nesse sentido, edifícios residenciais se disseminam por inúmeros bairros, com uma tendência clara de expansão no sentido sudoeste. Nos anos de 1940, nao apenas o Jardim América, como também os demais bairros jardim implantados - Jardim Europa, Jardim Paulistano, Pacaembu, Alto da Lapa atingem precos equivalentes aos de terrenos localizados em bairros em processo de verticalização, como Higienópolis e Perdizes (Cogep, 1979). Assim, o setor sudoeste é foco de duplo processo de valorização: via verticalização e via bairros jardim (FELDMAN: 2005: 146).

Em 1933, o município de Ribeirão Preto adota, para regular as suas leis urbanísticas, o Código de Obras Arhur Saboya da cidade de São Paulo. Esse cídigo embasará no município um novo zoneamento, dividido em quatro partes: Zona Central, Zona Urbana, Zona Suburbana e 
Zona Rural. ${ }^{39}$ A própria nomenclatura das zonas permanece a mesma do zoneamento da cidade de São Paulo, que definia os seus perímetros em função dos melhoramentos urbanos e do tipo de ocupação contidas em cada uma das zonas. Essa divisão da cidade era utilizada, principalmente, para estabelecer a cobrança do Imposto de Viação e Predial.

Quanto aos procedimentos de construção, o novo Código estabelece em Ribeirão Preto o seguinte:

As edificacões na rua General Osório, no trecho compreendido entre a Praça Shimidt e a rua Barão do Amazonas e a Praça 15 de Novembro, além dos preceitos gerais desta lei, devem ainda satisfazer às seguintes condicões:

$\int 1^{\circ}$ não terão menos de dois pavimentos sem contar o embasamento.

$\int 2^{\circ}$ nas ruas General Osório e Praça 15 de Novembro, a altura máxima dos prédios será de trinta metros e o número de andares será no máximo quatro, inclusive térreos.

O artigo 152 sofrerá a seguinte modificação: as construcões ou reconstrucões na avenida Independência, em toda a extensão, inclusive os prolongamentos, terão no minimo dois pavimentos e obedecerão ao recuo de seis metros (apud SANCHES: 2003: 2003)

Dessa maneira, a criação dos primeiros loteamentos residencias na zona sul de Ribeirão Preto será realizada para abrigar as famílias que se retiravam dessa região central, que vinha mudando de função. Entretanto, esse deslocamento é antecedido por uma ocupação salubre dessa área mais alta do núcleo urbano, situada ainda dentro do antigo Patrimônio da Fábrica da Matriz. Neste vetor de crescimento da cidade, acontece uma ocupação material que antecede a criação dos bairros exclusivamente residencias da década de 1940: Jardim Eugenia; Alto da Boa Vista e Jardim Sumaré. Durante as três primeiras décadas do século XX, os bairros serão ocupados na esteira da instalação de edifícios como o $1^{\circ}$ Grupo Escolar; o Gynasio do Estado; os colégios religiosos dos Metodistas, Maristas e das Irmãs Ursulinas, além do Estádio da Rua Tibiriçá, pertencente ao Commercial Foot-Ball Club.

No livro do memorialista Rubem Cione (1997), História de Ribeirão Preto, é apresentado o seguinte depoimento sem, entretanto, citar o seu autor:

\section{ALTO-CIDADE}

"A autenticidade toponômica de Ribeirão Preto foi respeitada desde sua origem até as primeiras décadas do século, quando a cidade se limitava das margens do Retiro para os altos da rua Bernadino de Campos, era o centro urbano. para cima do córrego do Retiro, toda área denominava-se Barracao. Separada pela velha estação da Mogiana estendia-se a Vila Tibério, e ao dobrar o fim da rua Saldanha Marinbo, comeşava o bairro da República. Até ai a autenticidade guardava as proporções originais.

Depois teve início a imitação toponômica dos bairros da Capital do Estado, e a grande São Paulo deu a grande Ribeirão Preto. Sedparou-se o Barracao dos Campos Elíseos, bairro de São Paulo, até então residência palaciana do governo do Estado, que por sua vez prende-se aos Champs Elysées da França, onde Napoleão construiu seu palácio. E a imitação de nomes de bairros da Capital foi-se estendendo pelos novos aglomerados citadinos. Primeiro foi Higienópolis, que abrange o alto da cidade até oslimites da Avenida 9 de Julbo.

Foi pouco depois de 1935 que a parte alta da cidade recebeu urbanização intensa, e, consequentemente a formação de bairros de alto padrão arquitetônico. (CIONE: 1997: 613)

39 A identificação das zonas pode ser feita numa tabela elaborada por Karla Sanches (2003) com a evolução da divisão das zonas em um mapa do município. A tabela será apresentada no tópico 3.4. 


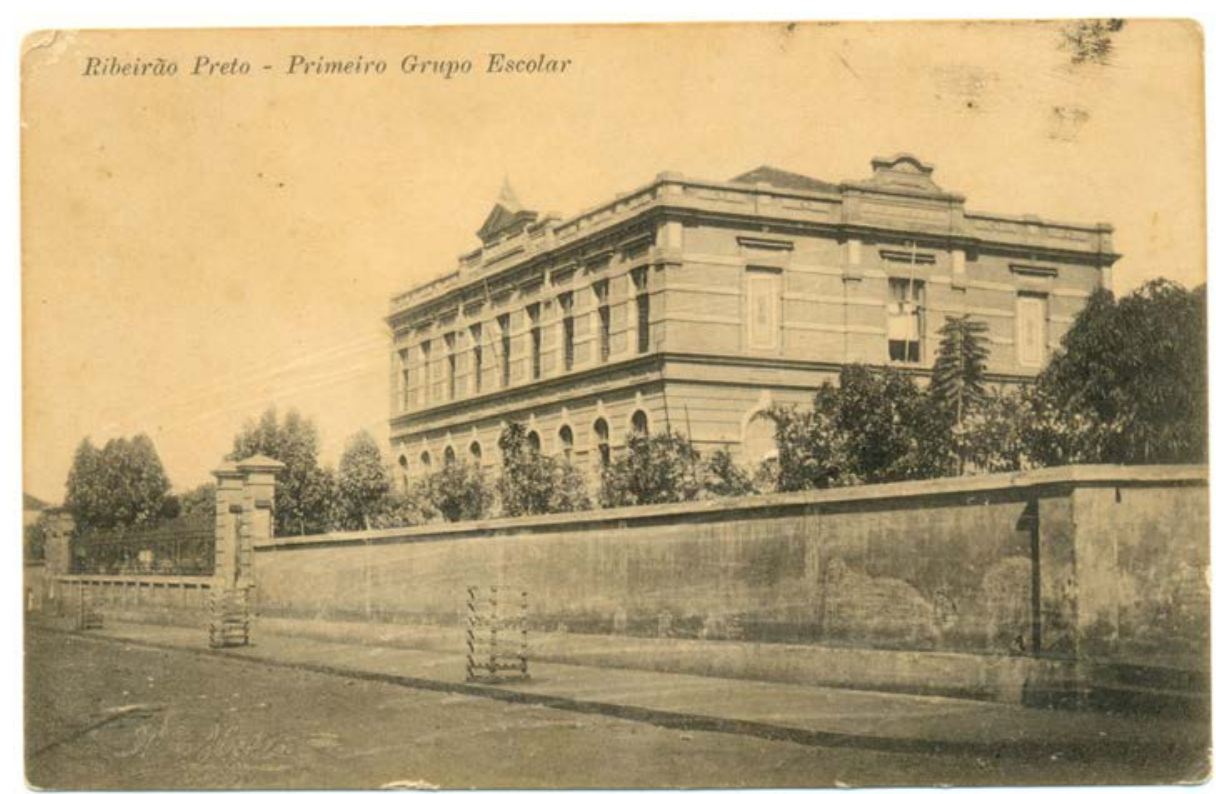

Figura 25: O edifício do Primeiro Grupo Escolar instalado na rua Lafaiete definindo a tendência de ocupação da parte alta da cidade. Fonte APHRP.

Segundo Cione (1997), a construção do edifício do Primeiro Grupo Escolar é iniciada após Arthur Diederichsen doar ao Governo do Estado um terreno de oito mil metros quadrados, sendo finalizada em 1902 numa quadra fronteira à recém-inaugurada catedral da cidade. A articulação para a construção do prédio para o Grupo Escolar em Ribeirão Preto tinha sido realizada por Luiz Pereira Barreto, então deputado estadual, que, junto ao senador José Guimarães Junior, futuro patrono da escola e político próximo a Prudente de Morais no Partido Republicano Paulista, protocolavam os requerimentos ao presidente do Estado, Bernardino de Campos.

A doação do terreno permitiu que o Grupo Escolar deixasse o prédio rústico que ocupava na rua Barão do Amazonas, no centro da cidade, permitindo sua locomoção para essa região, que vinha se consolidando como um espaço privilegiado pelos atores políticos republicanos. $\mathrm{O} 1^{\mathrm{a}}$ Grupo Escolar se diferenciaria por ocupar um lugar mais distinto da cidade, onde os filhos da elite cafeeira receberiam a instrução básica. A localização do seu terreno pode ser conferida na ata:

Foi lida a escritura de doação de um terreno multado, entre as ruas Visconde de Inhaúma, Lafayette e Barão do Amazonas, que fažem à Câmara Municipal, para nele ser edificado o Grupo Escolar, Tenente-Coronel Arthur Diederichsen e sua mulher D. Adelaide Araíjo Diederichsen, passada no $1^{\circ}$ Tabelião desta cidade em data de 3 do corrente. Sobre ela pediu a palavra o dr. João Caetano Alves, e requeria que se incerisse na acta um voto de louvor a esse cavaleiro e se oficiasse ao Governo do Estado para que fosse dado ao Grupo que se edificasse nesse terreno o nome de Grupo Escolar Coronel Arthur Diederichsen (CIONE: 1997: 219)

Segundo Cunha (2002), durante a Primeira República, apenas três escolas de ensino secundário existiam no Estado de São Paulo, e o Ginásio do Estado de Ribeirão Preto estava entre elas como uma escola seletiva e aristocrática, frequentada principalmente pela elite local. A ideia de instalar a escola na cidade surge em 1906, numa visita do Secretário do Interior do Estado, Gustavo de Godoy, em que Luiz Pereira Barreto, num banquete na Câmara Municipal, realiza um discurso sobre a importância de se criar o Ginásio para a formação mental de seu povo. O secretário se incumbe de levar esse desejo junto ao governador Jorge Tibiriçá, como uma demanda pelo apoio 


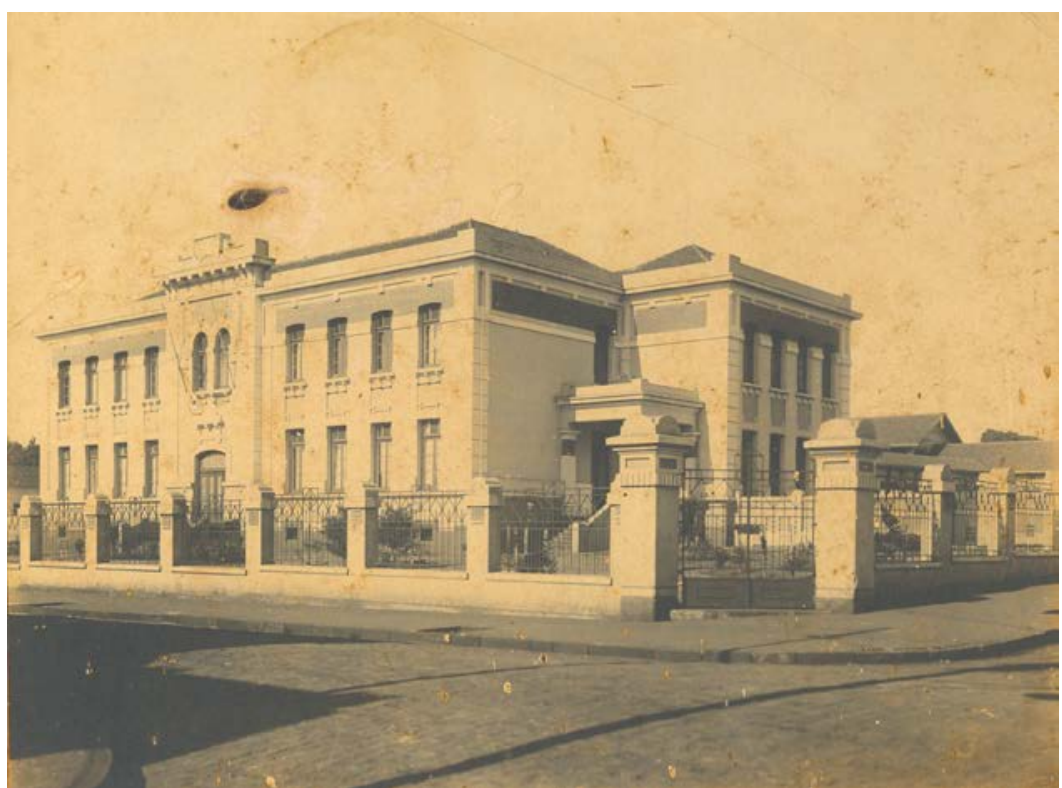

Figura 26: O edifício do Ginásio do Estado, entre as ruas Rui Barbosa e Campos Sales, e o colégio dos Metodistas na rua Florêncio de Abreu. Fonte: APHRP.

que Joaquim da Cunha Diniz Junqueira havia dado a sua candidatura em 1904.

Logo, a Câmara dos Deputados, em 1907, aprova a lei de criação do terceiro Ginásio do Estado de São Paulo, com um programa de ensino semelhante ao dos ginásios da capital e de Campinas, destinando 62 contos de réis para as despesas e pagamentos dos professores. Os primeiros professores eram ou se tornariam grandes figuras da política municipal, como Fábio de Sá Barreto, futuro interventor federal, Joaquim Macedo Bittencourt, Intendente Municipal durante toda a década de 1910, e os vereadores de oposição João Pedro da Veiga Miranda e Renato Jardim, além de outras figuras que estariam às voltas com o jogo de alianças em torno do poder político local.

A arborização das ruas, a limpeza pública, os calçamentos, as obras de saneamento, os encanamentos de água e esgoto serão realizados prioritariamente nessa região. As praças Aureliano de Gusmão e Antônio Honório recebem um tratamento especial de jardins, ressaltando o ar bucólico da parte mais alta da cidade, privilegiada pelas suas visadas e arejamento. O relatório do Intendente Municipal Joaquim Macedo Bittencourt se inicia de maneira bastante ufanista no que se refere aos melhoramentos da cidade, apontando a construção de praças nessa região:

Outro jardim de estylo moderno, de magnífico aspecto, foi feito na Praca 13 de maio, em frente a grandiosa cathedral que alli se está edificando. Não se poude ajardinar toda a Praça porque os andaimes e o trânsito de carraças com materiaes para essas obras impediam que se fizesse qualquer serviço na sua proximidade.

Logo que cesson este obstáculo, em fins do anno passado, deu-se começo ao jardim, traçando-se o seu plano, removendo-se a terra e formando-se os canteiros, que faltam somente se plantado.

Embelezou-se também a Praça Barao do Rio Braco com um pequeno jardim, que circunda a herma a que acima me referi.

A Figura 27 representa, em primeiro plano, a Catedral de Ribeirão Preto, situada na Praça 13 de maio, sendo possível enxergar, no segundo plano da imagem, os edifícios construídos entre 


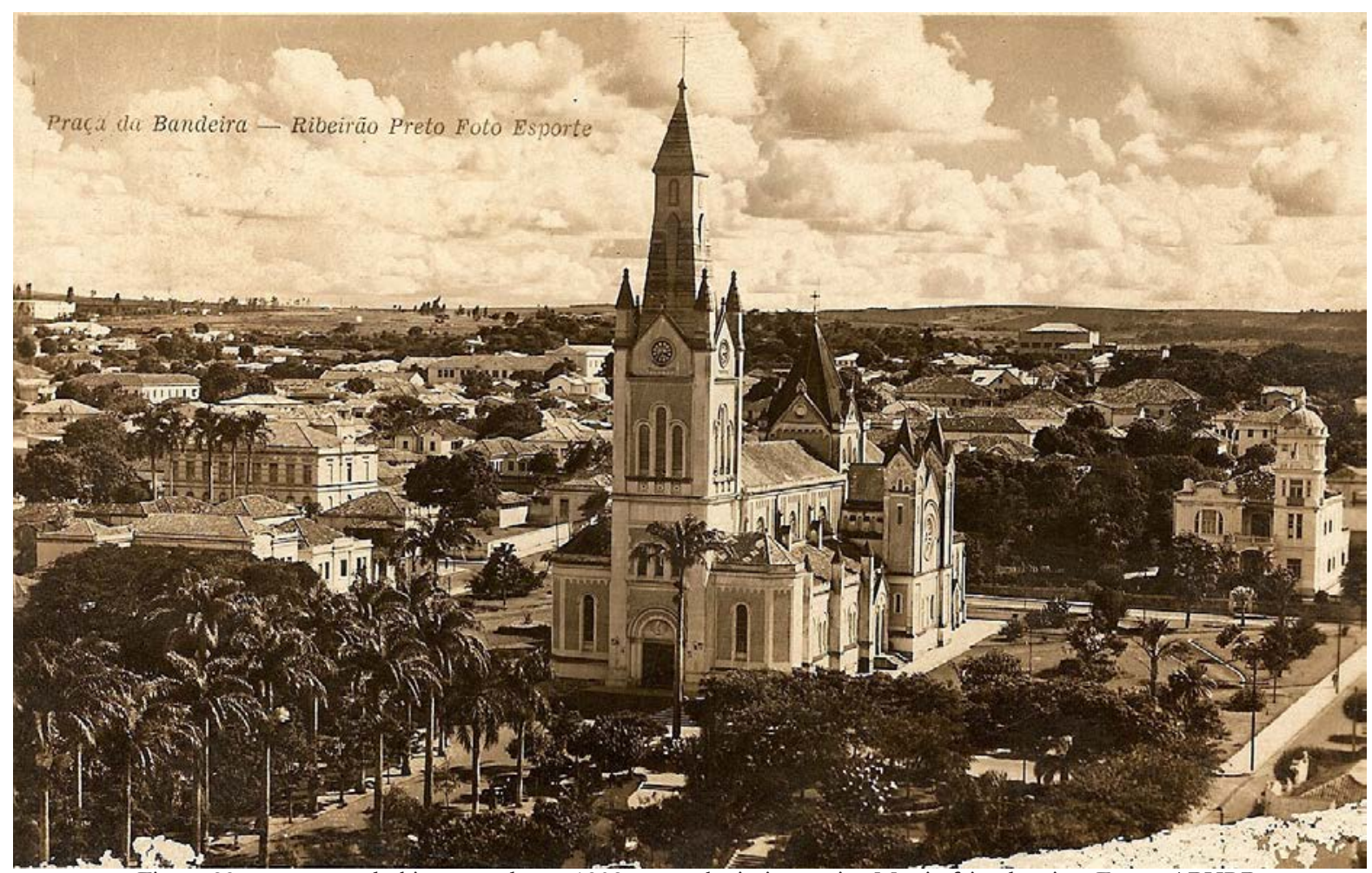

Figura 29: a nova catedral inaugurada em 1902 para substituir a antiga Matriz feita de taipa. Fonte: APHRP

esta Igreja e a Avenida Nove de Julho como: o $1^{\circ}$ Grupo Escolar e o Palácio Episcopal. No fundo da fotografia, ao horizonte, se vê as glebas que serão ocupadas pelo Jardim Eugênia, Jardim Sumaré e Alto da Boa Vista. Nas imediações da rua Bernadino de Campos, ainda ocupada com casas rústicas de longos quintais, se destacará nessa época o campo do Commercial Foot-Ball Club, implantado no alto da rua Tibiriçá com a Bernadino de Campos, onde futuramente se instalaria o clube da Sociedade Recreativa de Esportes. O campo de futebol atrairia, dessa forma, a população de Ribeirão Preto que se encontrava bastante conectada com os acontecimentos das capitais brasileiras, e que se dirigiriam ao novo Estádio da Rua Tibiriçá para acompanhar a febre do novo sport. ${ }^{40}$

A extensão urbana para os bairros da zona sul da cidade será garantida pela lei n ${ }^{\circ} 270$, criada em virtude das festividades do centenário da independência - "aquisição de terrenos para a abertura da Avenida Independência a partir da extremidade da rua Tibiriçá a quatro metros do fundo do Commercial Foot-Ball Club" (VALADÃO: 1997: 84). Inaugurada em 1922, a Avenida Independência havia sido idealizado pelo prefeito João Rodrigues Guião segundo um ideal de modernização expresso em uma série de obras realizadas em inúmeras cidades brasileiras em virtude da comemoração do centenário da independência do país.

40 Ver Sevcenko, N. Futebol, Metrópoles e Desatinos. Revista USP. São Paulo. no 22, pp. 30-37. jun-jul-ago, 1994. A referência ao conto "Corinthians 2 X Palestra 1" do escritor e jornalista Antonio de Alcântara Machado: "Desde o grande boom esportivo de 1919, quando o futebol se tornou uma mania que galvanizou toda a juventude da cidade, o então estudante Alcântara Machado já se destacava como entusiasta, compondo o grupo que criou a Liga Atlética da Academia do Largo de São Francisco, a primeira associação atlética universitária. Os acadêmicos cumpririam à risca essa sua determinação, ainda mais Alcântara Machado, por sua própria conta e por conta de sua percepção arguta que tinha da profunda transformação cultural que engolfava a sociedade paulista". 


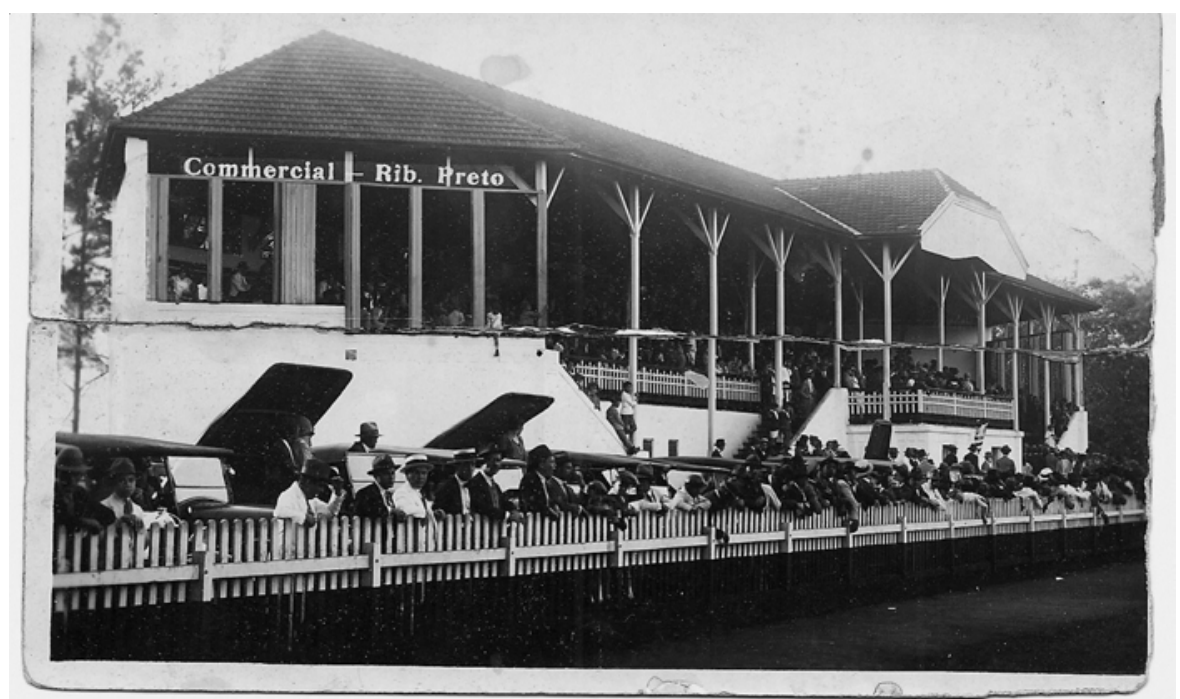

Figura 30: Toda elegância para acompanhar o novo sport inglês no Estádio do Commercial Football Club localizado entre a rua Tibiriça e a Avenida Nove de Julho. Fonte: APHRP.

Nestor Goulart Reis Filho (2000) cita como exemplo das festividades o conjunto composto pela urbanização do Vale do Anhangabaú, a reforma da rua Líbero Badaró e a abertura da Praça do Patriarca. O plano de modernização da cidade de São Paulo no Centenário da Independência ainda incluía a reforma da Praça da Sé, a criação do Parque D. Pedro II na Várzea do Carmo, além da abertura da Avenida do Estado e da construção do Parque da Independência. Para fechar o conjunto que integraria as comemorações do Centenário da Independência, Victor Dubugras, que já havia passado por Ribeirão Preto, é contratado para projetar o conjunto paisagístico da Ladeira da Memória.

Ribeirão Preto procurava se associar, através da construção de novos conjuntos urbanísticos ao movimento de transformações urbanas das cidades capitais brasileiras. O Rio de Janeiro, paradigma dessas reformas, antes mesmo do Centenário da Independência havia montado um grande cenário burguês com a reorganização de sua área central, principalmente com as demolições para a abertura da Av. Central e de um concurso de fechadas para novos edifícios. Os prefeitos de Ribeirão Preto, após 1932, em referência à Revolução Constitucionalista, colocando-se ao lado de diversas cidades brasileiras que procuravam afirmar a modernidade e o dinamismo do regime republicano.

Contudo, a primeira rua de Ribeirão Preto que teve uma regulamentação de fachadas no seu Código de Postura foi a General Osório. O Código pretendia estabelecer um padrão arquitetônico aos edifícios que faziam a fachada da Praça XV de Novembro ao estabelcer a obrigatoriedade de possuir a partir de 1920 o gabarito de dois andares. Na mesma década, seria a vez da Avenida Independência ter os padrões arquitetônicos de seus edifícios regulamentados. A Lei Municipal ${ }^{\circ}$ 277 alterava as determinações do Código de Posturas de 1921 sobre as construções da atual Avenida Nove de Julho, estabelecendo que todos os prédios construídos nela possuiriam o afastamento de seis metros do alinhamento dos portões de entrada na avenida. Além disso, esses edifícios do mais novo bulevar da cidade seriam exclusivamente residenciais, com jardins fechados de gradis em suas 


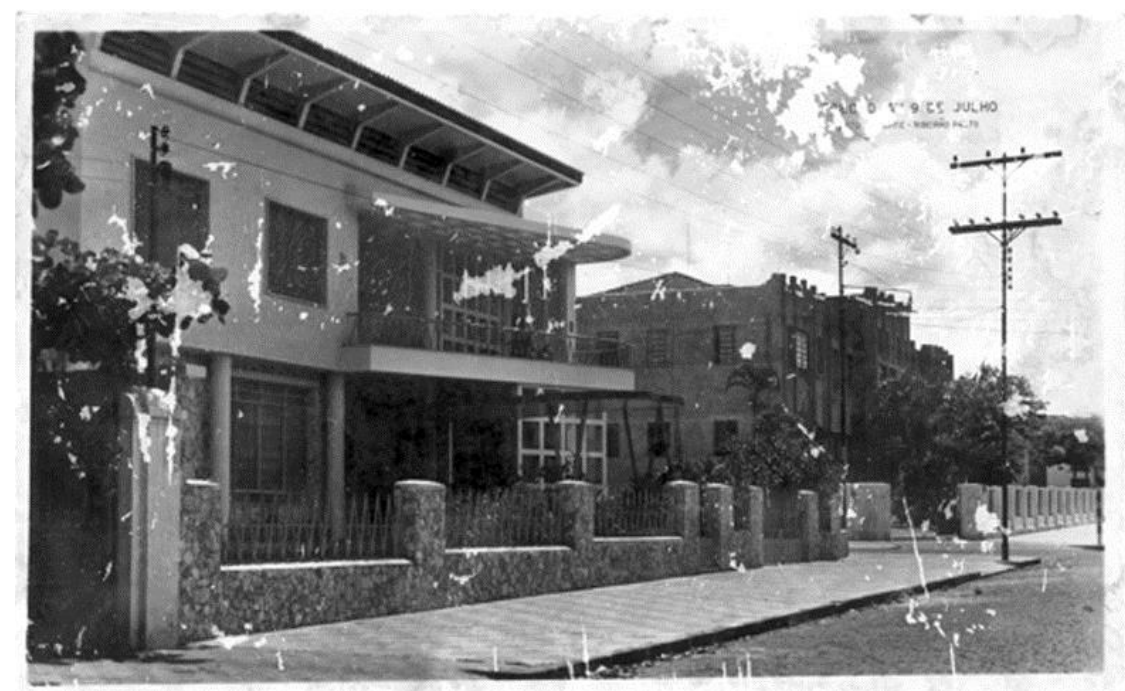

Figura 31: O padrão arquitetônico das novas residências na Avenida Nove de Julho. Fonte: APHRP.

fachadas. ${ }^{41}$

Mais tarde, no ano de 1949, durante prefeitura de José de Magalhães, o prolongamento da Av. Nove de Julho é retomado com o objetivo de se concluir a primeira perimetral da cidade. As obras são regulamentadas pela lei municipal no 101, de 8 de julho de 1949, que declara de utilidade pública os terrenos de diversas chácaras que se encontravam na faixa de terra que a avenida ocuparia. Assim, ela se tornaria, junto com as avenidas dos canais dos rios, o terceiro bulevar da cidade. Calçada com paralelepípedos, em seu canteiro central seria plantada uma fileiras de árvores Sibipirunas, formando uma faixa verde entre o quadrilátero central e os novos bairros da Zona Sul.

Para implantar a Avenida seria necessário, contudo, a realização das desapropriações de diversos terrenos ao longo de sua abertura, como pode ser visto em uma correspondência entre o Chefe de secção de Plantas Cadastrais e o Diretor de Viação e Obras Públicas:

Para o prolongamento da Avenida Nove de Julho, no qual, o traçado atravessa os terrenos da Vila Higienópolis, aprovada há muitos anos, tenho a bonra de enviar-lhe memoriais e plantas do reloteamento da quadra, entre as ruas: Quintino Bocainva, rua Olavo Bilac e a rua Vicente de Carvalho, para os estudos de desapropriação, por via judicial ou acordo amigável (CORRESPONDENCIA: 1956)

A Lei no 101 irá dispor uma relação contendo a metragem dos terrenos desapropriados apontando os valores pagos, respectivamente, a cada um dos proprietários através de uma tabela subdividida entre os quarteirões ao longo da Avenida Nove de Julho:

\section{LEI No 101}

de 8 de julbo de 1949.

Declara de utilidade pública, terrenos das avenidas nove de julho e independência, Para abertura de rua.

Faço saber que a Câmara Municipal decretou e eu promulgo a segninte:

Artigo $1^{\circ}$ - nos termos do n.IV do arti 16, da lei n. 1, de 18 de setembro de 1947, combinando com os Decretos-leis ns. 3.365 e 4.152, respectivamente de 21 de junho d 1941 e 6 de março de 1942, ficam declarados de utilidade pública, a fim de serem recebidos por doação, on adquiridas 
mediante desapropriação judicial ou amigável, as áreas de terrenos abaixo caracterizadas, necessárias ao prolongamento das avenidas nove de julho e independência, a saber:

AVENIDA NOVBE DE JULHO

$\begin{array}{lcccc}\text { NOMES } & \text { para avenida } & \text { mais lado par } & \text { mais lado impar } & \text { to tar } \\ \left(\mathrm{m}^{2}\right) & & & \\ \text { Manoel Peres } & 1.920,00 \mathrm{~m}^{2} & 864,00 \mathrm{~m}^{2} & \\ \begin{array}{l}2.784,00 \\ \text { Waldemar B. Pessoa }\end{array} & 759,00 \mathrm{~m}^{2} & 341,55 \mathrm{~m}^{2} & 1.075,25 & 2.175,00\end{array}$

total

(LEI No 101: 1949)

O $2^{\circ}$ Artigo da lei $n^{\circ} 101$ discorria sobre o caráter legal das desapropriações objetivadas para o prolongamento e ampliação da avenida, além das áreas que compreenderiam propriamente o arruamento da via. Contudo, outras zonas dentro dos quarteirões dos dois lados da Avenida também seriam desapropriadas em virtude da consequente valorização dos terrenos após a conclusão dos trabalhos, o que demonstra uma atuação especulativa da Prefeitura Municipal. Já o Artigo $5^{\circ}$ dispunha sobre as concordâncias de preço e pagamento estipuladas para desapropriação, que caberia aos proprietários aceitarem amigavelmente. Por fim, rememorando a engenharia financeira dos Intendentes da Primeira República, o prefeito do Partido Trabalhista, José de Magalhães ,estabeleceria o seguinte no oitavo artigo da lei nº101:

Artigo $8^{\circ}$ - as despesas com a execução desta lei, correrão por conta da verba orçamentária consignada para o presente exercício, e dos créditos suplementares oportunamente abertos. (LEI No 101:1949)

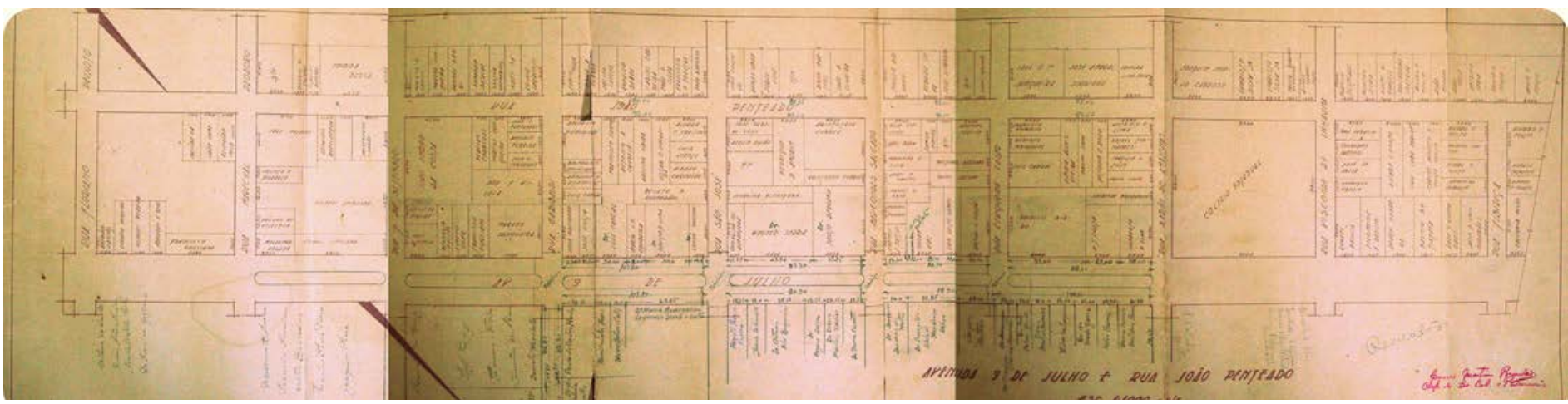

Figura 32: planta de demarcação dos terrenos desapropriados para a construção da Av. Nove de Julho. APHRP.

\subsection{A política na cidade após 1930.}

Durante um período de 20 anos, entre as décadas de 1940 e 1950, a cidade de Ribeirão Preto viveu um momento crucial de seu desenvolvimento urbanístico. Na verdade, mesmo antes desse período, a cidade já havia passado durante a Primeira República por inúmeras reformas urbanas que pautaram os balanços financeiros da Câmara Municipal sendo objeto de discursos visionários sobre urbe ribeirão-pretana. Todavia, durante aqueles 20 anos, se assistiram a alguns momentos de inflexões políticas cruciais para o subsequente desenvolvimento da cidade no âmbito dos dilemas do urbanismo moderno. 


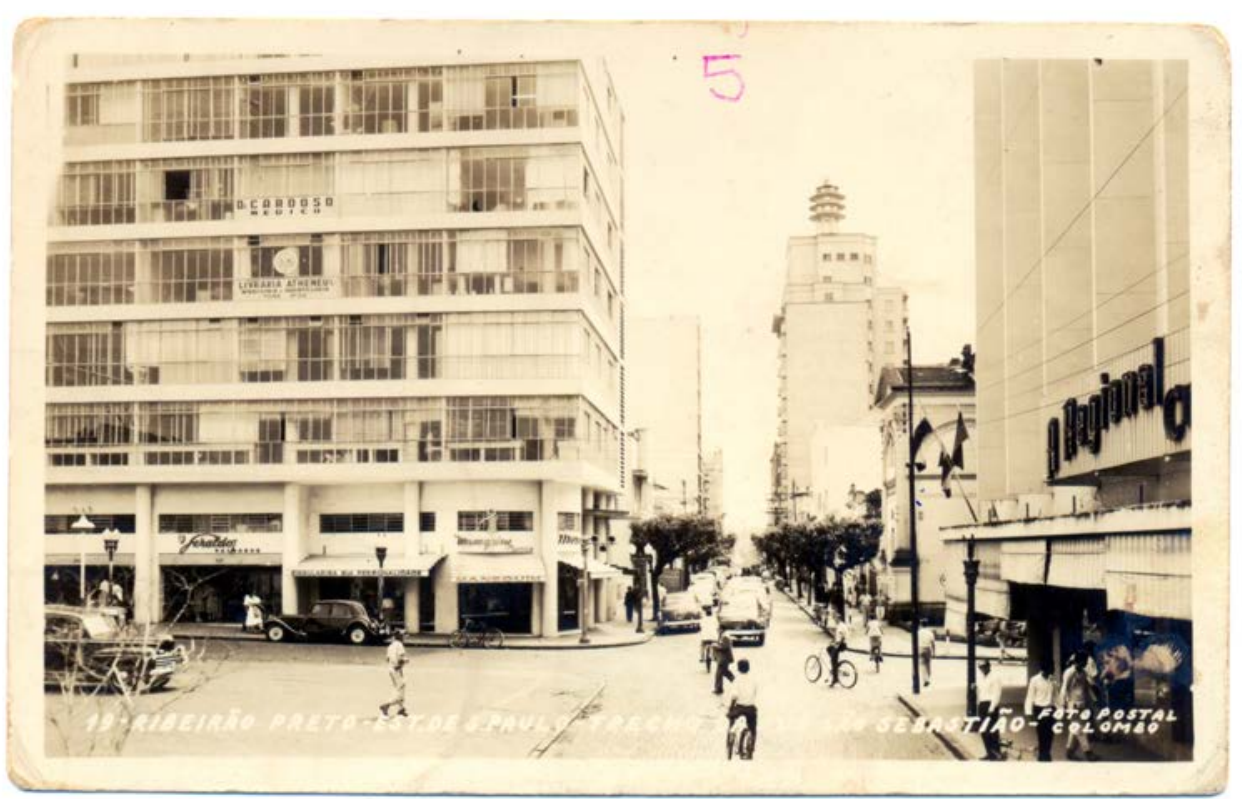

Figura 33: a rua São Sebastião no centro de Ribeirão Preto em claro processo de verticalização. Fonte: APHRP.

O final da Primeira República havia sido marcado pela redução da autonomia municipal, com os prefeitos sendo indicados, após o golpe de 1930, pelos interventores federais. A partir de 1931, o município passa a ser submetido ao escrutínio do Departamento de Assistência aos Municípios - DAM - órgão criado pelo Governo Federal com o objetivo de realizar a centralização do controle dos gastos e da arrecadação dos municipios brasileiros. A atuação desse órgão gera a redução do endividamento de Ribeirão Preto, que havia sido até então a matriz do financiamento dos melhoramentos urbanos durante a Primeira República. Apesar da arrecadação municipal não sofrer uma drástica alteração em relação ao período anterior, com a receita sendo ainda majoritariamente composta pelo Imposto de Indústrias e Profissões e o Imposto Predial, a autonomia financeira do município é crucialmente reduzida pela ação do DAM no que toca ao endividamento.

Ao abrir o relatório do primeiro Prefeito Municipal de Ribeirão Preto por nomeação federal, se vê que ele não seria mais apresentado aos vereadores da Câmara Municipal, mas ao Interventor Federal do Estado de São Paulo, coronel João Alberto Lins de Barros, e ao Secretário do Interior de Negócios, Arthur Neiva.

\section{SENHOR INTERVENTOR}

\section{Introdução}

Quando assumi o exercício do cargo de Prefeito do município de Ribeirão Preto, por nomeação de $V$. Excia. en já sabia que ia ocupar um posto de sacrificios.

Corria insistentemente pela cidade que a situação financeira da Prefeitura era afflictiva: diəzia-se que a abertura da Avenida do Café, iniciada na administração do Cel. José Martimiano da Silva e ainda não concluida, consumira mais de um milhar de contos; falava-se que, com as obras de calcamento, iniciadas na administração do Dr. João Rodrigues Guião, continuadas na do cel. José Martimiano, e, intensificadas, imprudentemente, na do Dr. Joaquim Camillo de Moraes Mattos, e com a construção do Leprosario de Casa Branca e abertura e conservação de estradas de rodagem, a Municipalidade despendera mais de quatro mil contos; propalava-se que tudo isso e mais a crise do café, despezas inúteis, como a acquisição de um automóvel "Lincoln" para o projectado banquete ao Dr. Julio Prestes, gastos inopportunos (...) [que] tinham forçado a Municipalidade a contrabir empréstimos elevadíssimos a juros por vezes onerosos (RIBEIRO: 1931: 5). 
A preocupação quanto ao endividamento da Câmara Municipal e os seus gastos inoportunos, como a visita do candidato do PRP, Júlio Prestes, que seria deposto pela Revolução de 1930, soava bastante diferente da tônica ufanista em relação ao progresso material da cidade das gestões dos Intendentes da Primeira República. No relatório de Joaquim Macedo Bittencourt, o médico baiano que foi prefeito durante a crise de falta d'água na década de 1910, aquele afã pelos novos empréstimos financeiros fica bastante explícito:

$\mathrm{Na}$ nossa administração contrahimos também dividas, e não pequenas, mas ellas não tiveram a mesma origem. Administravamos uma cidade em formação, que se tinha desenvolvido rapidamente e não tinha os melhoramentos que seu desenvolvimento exigia; a exiguidade da renda municipal não permitia que se organizassem serviços que já eram imprescindiveis: a posição de Ribeirão Preto em face dos municípios vizinhos, a sua apregoada opulência, o seu constante adiamento, reclamavam dos seus dirigentes emprehendimentos correspondentes ao papel de destaque que já representa como centro de uma grande zona, tínhamos desejo, todos nós, de bem cumprir os nossos deveres, queríamos trabalhar, e, portanto, não podíamos deixar de recorrer ao crédito para obter o dinheiro que nos faltava (BITTENCOURT: 1920: 17)

A partir de dezembro de 1930, portanto, os primeiros prefeitos interventores irão procurar conduzir os negócios do município segundo os parâmetros estabelecidos pelo DAM. Apesar desse controle federal no governo municipal, as sedes dos primeiros partidos políticos que irão atuar durante a Era Vargas começam a ser criadas em Ribeirão Preto - a Ação Integralista Brasileira (AIB), o Partido Democrático (PD), o Partido Constitucionalista (PC) e, mais tarde, ao final do Estado Novo, os três partidos que irão aglutinar as principais forças políticas na Câmara Municipal: o Partido Trabalhista Brasileiro (PTB), a União Democrática Nacional (UDN) e o Partido Social Democrático (PSD).

Diferente da Primeira República, aparecem na lista de candidatos à prefeitura durante o Intermezzo Democrático (1934-1936) integrantes de outras classes sociais, principalmente entre os políticos do Partido Constitucionalista, que apresentava um jornalista, presidente da União Geral dos Trabalhadores, como candidato. Contudo, entre 1937 e 1945, inspirado por teorias administrativas centralizadoras, o poder executivo central foi novamente fortalecido, e apesar de os municípios ainda possuírem algumas prerrogativas, como a eleição de vereadores e a criação de alguns impostos, a presença dos interventores ocupando os antigos cargos de Intendentes ou Prefeitos Municipais diminui muito a autonomia municipal, alterando a dinâmica política nas esferas locais de poder. Assim, o Estado Novo interdita nesse período os partidos políticos.

Entretanto, outra medida do Estado Novo teria um impacto contrário na vida política do município de Ribeirão Preto, pois, ao criar o sistema de sindicatos trabalhistas vinculados ao Ministério do Trabalho, Getúlio Vargas fez surgir na cidade inúmeros sindicatos de diferentes setores profissionais. ${ }^{42}$ Os antigos políticos da Primeira República perdiam cada vez mais força na cidade, e uma das últimas manifestações políticas daquele grupo de vereadores e intendentes ocorreu durante a Revolução Constitucionalista de 9 de Julho de 1932. A Comissão Diretiva do PRP, de maneira entusiástica, lança uma mensagem encabeçada por Joaquim Diniz da Cunha

42 Uma lista das categorias que se reuniram em torno da inauguração do estádio de futebol do Clube de Esportes dos Trabalhadores é apresentada por Walker, T. op. cit, p. 88. 
Junqueira, já bastante adoecido, declarando a "restauração constitucional e a autonomia de São Paulo". Durante os dias de conflitos é formado na cidade o "Centro Paulista Pró-Constituinte", que possuía nomes conhecidos na política republicana, como Camillo de Moraes Mattos e João Pedro da Veiga Miranda. O Partido Democrático (PD), todavia, que havia sido fundado pelo conselheiro Antonio Prado, mantém o seu apoio na localidade às forças de Getúlio Vargas.

No ano de 1945, terminaria em Ribeirão Preto o governo do interventor da Era Vargas, Fábio de Sá Barreto. Político oriundo de uma importante família de fazendeiros de café, Sá Barreto era sobrinho do Dr. Luís Pereira Barreto, o entusiasta do positivismo agrícola que havia migrado para Ribeirão Preto após se tornar proprietário de uma fazenda em Cravinhos, Fàbio de Sá Barreto havia sido uma figura influente na política local desde a Primeira República, exercendo oposição à Joaquim Diniz da Cunha Junqueira na Câmara Municipal e no Diretório do Partido Republica Paulista. A sua nomeação como interventor federal fazia parte do esforço de Getúlio para agradar os municípios de São Paulo dando poder a alguns políticos locais dissidentes para dirigir os governos locais.

O governo do interventor Sá Barreto, mesmo com um nítido enfoque urbano, não se caracteriza como uma ruptura efetiva em relação às gestões dos Intendentes Municipais republicanos. Porém, mesmo estando bastante vinculado aos produtores de café, o interventor passa a representar um reposicionamento no jogo político municipal. Sá Barreto, apesar de oriundo de uma oligarquia agrária, galgava ao final dos anos 30 o carisma de uma figura política vinculada ao espaço urbano. A tônica de sua gestão como interventor foi basicamente um aprofundamento das obras de embelezamento da cidade que já haviam sido iniciadas nas primeiras décadas do século XX.

A sua gestão realiza a remodelação de praças centrais e cria o Bosque Municipal quase limítrofe ao centro da cidade, ainda amplia o sistema sanitário municipal, concluindo a canalização do ribeirão Preto e do córrego do Retiro em obras que já se arrastavam há décadas tendo sido iniciadas no final do século XIX. Os canais demarcariam nos anos 30, finalmente, o perímetro central da cidade, com as duas avenidas bulevares no fundo dos vales, além do terceiro bulevar caracterizando o desenho urbano de Ribeirão Preto. Entretanto, com o posicionamento do Brasil contra as forças do Eixo durante a Segunda Guerra Mundial, o Estado Novo começa a se enfraquecer e o governo de Fábio de Sá Barreto, então com 68 anos de idade, sofre inúmeras críticas da imprensa local. Em maio de 1944, por problemas de saúde, Sá Barreto renuncia por problemas de saúde, sendo substituído por Alcides de Araújo Sampaio, integrante da "ala jovem" do antigo Partido Republicano Paulista, que depois da abertura política migra para o PSD, partido político que havia acolhido a elite burocrática getulista. Este fato será decisivo para o convite realizado pelo interino Alcides de Araújo Sampaio ao urbanista José de Oliveira Reis vir a Ribeirão Preto elaborar um projeto de Plano Diretor.

As eleições para a Assembleia Constituinte de 1946, além das eleições legislativas estaduais, marcariam o ressurgimento da política partidária. Ao final do Estado Novo, a maioria dos partidos 
nacionais já possuíam suas organizações locais em Ribeirão Preto. A Constituição de 1946 é bastante influenciada pelo movimento municipalista, reestabelecendo o regime de eleições para os cargos de Prefeito Municipal, além de outras prerrogativas administrativas que marcaram este período como o auge do federalismo no Brasil. Thomas Walker (2000) define a situação financeira do município de Ribeirão Preto nesse período como a seguinte:

A mudanca mais importante na receita municipal, no entanto, foi o resultado dos planos estaduais e federal de divisão de receitas estabelecidas na Constituicão de 1946. Os artigos 15, 20 e 21, respectivamente, garantiam o repasse para os municípios de receitas oriundas de tributos federais sobre combustiveis e lubrificantes, de tributos estaduais excessivos arrecadados no Municipio e de todos os novos tributos estaduais e federais. Apesar de a maioria dos Estados não cumprirem com suas obrigacõos perante essa legislação, o rico Estado de São Paulo foi uma das poucas exceşôes e, dessa forma, municípios como Ribeirão Preto foram imensamente beneficiados. De fato, os novos programas de divisão de receitas fizeram aumentar a arrecadasão pública do Municipio em aproximadamente 18\% em 1950 e em mais de 21\% em 1960. (WALKER: 2000: 104)

O fim do Estado Novo e a volta das eleições municipais para o poder executivo, em 1946, apesar de não representar outra ruptura com o governo de Fábio de Sá Barreto, traz novidades ao cenário político local. A extensão do direito de voto novamente à população se dá em meio a uma cidade maior e mais urbanizada. As polêmicas listas de eleitores, produzidas pelos antigos fazendeiros de café para arrebatar votos de seus colonos aos candidatos apoiados pelo PRP, não eram mais decisivas no jogo político. Inaugura-se nas eleições municipais algo que Getúlio Vargas já havia conquistado em âmbito nacional. A partir de então, a candidatura a qualquer cargo eletivo implicaria na conquista da simpatia da população em um posicionamento político enquanto uma liderança carismática. Essa popularidade será conquistada em Ribeirão Preto, principalmente, pelos prefeitos Alfredo de Condeixa Filho (1952-1955) e por Costábile Romano (1956-1959).

Antes deles, porém, José de Magalhães, candidato trabalhista à prefeitura municipal, vence as eleições de 1945 diante de uma vacilante campanha do candidato das "classes conservadoras" representadas pela UDN. O jovem advogado petebista, que despende enorme soma do tesouro do município para prolongar a avenida Nove de Julho, conduz o seu governo de forma populista tentando aumentar o seu carisma também entre as classes trabalhadoras. Assim, ele aumenta a receita municipal através da elevação do imposto recolhido aos proprietários de indústrias e, em 1950, num comício do candidato do PTB à presidência da República, recebe Getúlio Vargas de forma bem mais calorosa do que o seu rival Cristiano Machado, candidato do PSD.

A novidade trazida pelo voto da população aos candidatos à prefeitura era a de que o chefe do executivo não seria mais tão dependente do legislativo, isso geraria um distanciamento entre a Câmara Municipal e a Prefeitura. Desse modo, este período foi particularmente marcado por conflitos interfuncionais entre o prefeito e os vereadores. Todos os prefeitos eleitos entre $1945 \mathrm{e}$ 1964 entraram em conflito com a Câmara Municipal, chegando a lançar mão do veto executivo que só poderia ser derrubado por dois terços dos votos da Câmara.

O resultado das eleiçôes de dezembro de 1945 e de janeiro de 1947 deve ter sido dolorosamente decepcionante para os membros da UDN local. Em 1945, esses liberais democratas antigetulistas haviam nutrido grandes esperanças de que, finalmente, seu dia havia chegado. No entanto, o continuo sucesso da situação do PSD e o crescente carisma populista de Adhemar de Barros haviam despejado um balde 
de água fria sobre esses sonhos. Como consequência, no inicio da campanha para as eleições municipais de 1947, os líderes da UDN compreenderam que era imperativo um esforço bastante sério, caso o seu partido desejasse continuar sendo uma alternativa política viável. Estimulados por essa desagradável conclusão, alguns dos membros mais jovens, liderados por Wilson Roselino, reorganizaram o partido em março e abril e então iniciaram uma vigorosa campanha para eleger "udenistas". Métodos modernos de "propaganda e penetração" foram adotados. (...) Para dar credibilidade a esse tipo de pronunciamento, as organizaçôes distritais da UDN foram instaladas nos bairros da classe trabalhadora, uma seção para os trabalhadores foi criada dentro do partido, e pelo menos um trabalhador foi incluido na lista de candidatos a vereador da coligação UDN-PR (WALKKER: 2000: 113).

Em suma, os 20 anos cruciais ao urbanismo moderno no âmbito da política municipal podem ser divididos, basicamente, em duas partes: entre 1945 e 1951, quando o Partido Social Democrático (PSD) e o Partido Trabalhista Brasileiro (PTB), grupos políticos que gravitavam em torno da herança populista de Getúlio Vargas, estiveram no Poder Executivo, principalmente durante as gestões dos prefeitos Alcides Araújo Sampaio e José de Magalhães. Neste período a Câmara Municipal foi dominada pelos vereadores da oposição udenista anti Getúlio Vargas. Entre 1952 e 1961, por sua vez, esse quadro político se inverte, e a UDN, percebendo a importância do mecanismo do veto executivo, ocupará o Palácio do Rio Branco durante as gestões dos prefeitos Alfredo de Condeixa Filho (1952-1955) e Constábile Romano (1956-1959), além dos prefeitos interinos José da Costa (1955), Orlando Jurca (1959) e Áureo Noberto da Silva (1959). No mesmo período, os vereadores petebistas dominaram a Câmara Municipal.

\section{VEREADORES E DEPUTADOS DA VILA}

Logo na primeira legislatura após a queda do Estado Novo, em 1946, a Vila Tibério foi o bairro que mais vereadores deu a Ribeirão Preto. Todos eleitos pelo Partido Trabalbista Brasileiro - PTB. Foram eleitos naquela ocasião vereadores como José Velloni e José Delibo, bem como Guilherme Giro e Limpio Rossi (ambos 4 ou 5 mandatos). Horácio Arantes da Silva e Euclides Carneiro, que era ferroviário (CIONE: 1997: 561)

Apesar desse entusiasmo do memorialista Rubem Cione em relação aos vereadores trabalhistas do bairro mais popular de Ribeirão Preto, a Vila Tibério, a política municipal ao final do Estado Novo seria mesmo dominada pelos políticos conservadores da UDN, algo realmente crucial naquela dança de cadeira entre o poder executivo e o legislativo foi prerrogativa de veto que o executivo possuía diante das demandas legislativas da Câmara Municipal. Esse mecanismo se torna um fator decisivo durante a atuação da Comissão Especial do Plano Diretor da Cidade, montada em 1954 para organizar a tramitação do Plano Diretor do município. Após a articulação daquela capilaridade política promovida pelas organizações distritais da UDN nos bairros populares de Ribeirão Preto, este partido irá dominar o executivo municipal, principalmente, durante as gestões de Alfredo Condeixa Filho, Costábile Romano e de José da Costa, que era o prefeito interino durante a segunda visita do urbanista José de Oliveira Reis à cidade para realizar a palestra "O urbanismo e a sua influência no município". 


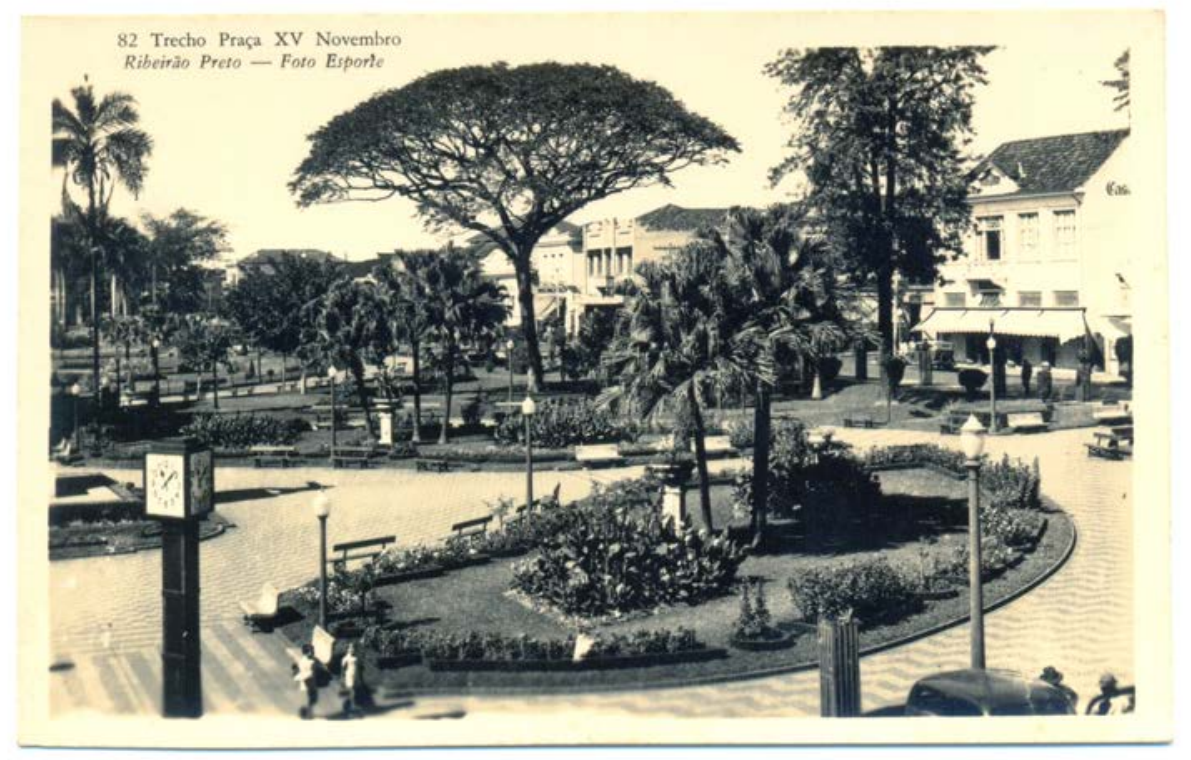

Figura 34: mais uma reforma na Praça 15 de Novembro durante a gestão do interventor Fabio de Sá Barreto. Na fachada da Praça é possível ver os sobrados de dois andares como previa o Código de Posturas de 1921. Fonte: APHRP.

\subsection{Um projeto de um Plano Diretor.}

A estruturação dos órgãos de ordenamento urbano de Ribeirão Preto é redefinida, segundo Karla Sanches (2003), pelo Ato Municipal nº de 1935, que cria a Diretoria de Obras e Viação em substituição à antiga Repartição de Obras da Câmara Municipal. Dividida em seis sessões, a Diretoria assume a competência da aprovação de plantas, além dos despachos sobre iluminação pública, transportes urbanos e a fiscalização de fábricas e demais indústrias do município. A criação da Diretoria de Obras e Viação de Ribeirão Preto também é fruto da adoção do Código de Obras Arthur Saboya, em 1933, que passa a exigir a estruturação de tais serviços administrativos. Assim, a sua criação está associada ao período de dissolução das Câmaras Municipais por Getúlio Vargas que a partir de 1930 passa a centralizar diversos atos da administração municipal.

A adoção do Código Arthur Saboya e a criação da Diretoria de Obras e Viação coincidem com o governo do interventor municipal Eduardo Leite Ribeiro, que havia sido nomeado pelo interventor estadual de Getúlio Vargas em São Paulo. Após um breve período em que os vereadores da Câmara puderam escolher o prefeito municipal, novamente em 1937 lhes é retirada essa prerrogativa com o advento do Estado Novo. Durante todo esse período, até 1945, o município será administrado por Fábio de Sá Barreto, que possuía uma amigável relação com Getúlio Vargas, recebendo-o em 1938 numa visita oficial que reuniu cerca de 30 mil habitantes. ${ }^{43}$

Como foi apontado no tópico anterior, o governo de Fábio de Sá Barreto continua os trabalhos de embelezamento da cidade, reformando os parques e as praças municipais. Desse

43 Ver WALKER, T. W. op. cit. p.96. 
modo, José de Oliveira é convidado para elaborar o Plano Diretor de Ribeirão Preto após em 1944 já na gestão do prefeito interino Alcides de Araujo Sampaio que substituíra o interventor Fábio de Sá Barreto, que vinha enfrentava problemas de saúde. O urbanista é apresentado na imprensa local da seguinte maneira:

\section{A remodelação de Ribeiráo Preto.}

Depois da administração municipal do sr. Fabio Barreto, que dotou a cidade de vários melhoramentos, já ajardinando as praşas, calçando grande parte das ruas, aumentando a canalização de águas bem como a canalização de exgotos e tantos outros serviços que tanto destacaram o periodo do seu governo, foi a municipalidade confiada ao espirito trabalhador e progressista do dr. Alcides Sampaio, que continuou a obra benemérita de seu antecessor, imprimindo um cunbo moderno a todas as suas realizaçoes.

Dando maior amplitude ao programa de execução dos serviços públicos, o atual Prefeito de Ribeirão Preto confiou ao dr. José de Oliveira Reis, engenheiro urbanista dos mais competentes e que durante vários anos foi assistente do famoso prof. Agache, autoridade máxima em assuntos de urbanismo, a tarefa de planejar a remodelaşão de nossa cidade.

O esquema do Plano Diretor é finalizado no ano de 1945 na administração do primeiro prefeito do PTB, José de Magalhães. Ribeirão Preto havia sido a cidade em que José de Oliveira Reis nascera, em 1903, no ano seguinte a uma forte epidemia de febre amarela, relatada na época com grande alarde como a moléstia do vômito negro. Durante sua infância, o urbanista acompanhara os melhoramentos sanitários da cidade da janela da casa de seu pai, na rua General Osório, que ladeava toda a extensão da Praça XV de Novembro. Dessa forma, sua infância esteve marcada por todas aquelas transformações urbanas do início do século XX, como as obras de canalizações dos rios

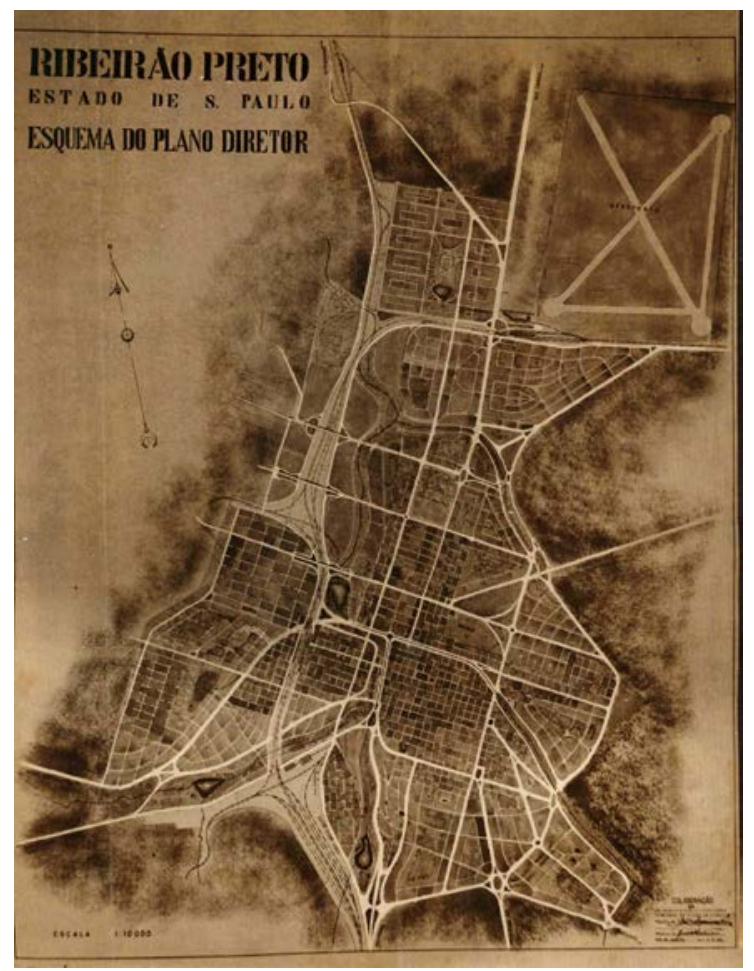
centrais, o calçamento das ruas, o ajardinamento de praças e a construção da rede de água e esgoto..

Oliveira Reis realiza os seus estudos fundamentais no Ginásio do Estado de Ribeirão Preto, colégio criado pelas reformas educacionais da Primeira República, tendo como professores os políticos que haviam polemizado na questão dos mananciais da cidade em 1912. Logo, o seu pai o envia ao Rio de Janeiro para cursar a Escola Politécnica, onde se forma como engenheiro civil em 1925, voltando ao Interior Paulista para trabalhar no Serviço de Abastecimento de Água do município de Rio Claro. Em 1933, Reis inicia sua extensa carreira profissional pelas instituições públicas de planejamento urbano da Capital Federal, se tornando um dos personagens do processo de

Figura 12: esquema viário do Plano Diretor. Fonte: APHRP.institucionalização do urbanismo. ${ }^{44}$

44 No momento em que elabora o Plano Diretor de Ribeirão Preto Oliveira Reis ocupava o cargo de Chefe da Comissão do Plano da Cidade do Rio de Janeiro, ver FARIA, Rodrigo S. de. José de Oliveira Reis, urbanista em 
Apesar de Oliveira Reis ter crescido no ambiente político da Primeira República, marcado por aqueles personagens do Partido Republicano Paulista, o seu retorno se dá em outro contexto, ao final do Estado Novo, num período em que os municípios reconquistavam autonomia financeira e administrativa. O movimento municipalista, nesse momento, se nutria de referências teóricas da administração e do planejamento estadunidense, postulando soluções técnicas desvinculadas de problemas políticos. No entanto, seria impossível realizar a esterilização do jogo político no processo de confecção e aprovação do Plano Diretor de Ribeirão Preto, e o esquema elaborado pelo urbanista será o motivo de um complicado conflito de interesses na Câmara e no Executivo Municipal da cidade.

A elaboração do Plano Diretor para Ribeirão Preto pelo urbanista José de Oliveira Reis, em 1945, ocorre num momento em que o zoneamento se caracterizava como um dos principais instrumentos de planejamento urbano. A viagem do urbanista para cidade se dá quando a Comissão do Plano da Cidade do Rio de Janeiro é transforma sob a sua chefia no Departamento de Urbanismo durante os anos de 1940. Na história do urbanismo brasileiro, esse período é caracterizado por Sarah Feldman (1997) como um momento de filiação ao pensamento norte americano tanto pelas teorias administrativas da Scientific Management School quanto pelo zonig, esta acaba se tonando uma ferramenta de ordenamento urbano bastante utilizada para tentar controlas o uso e a ocupação do solo das cidades brasileiras.

A legislação do zoneamento de São Paulo, ao final dos anos 40, já abrangia o conjunto da cidade dividindo o seu território urbano em zonas nas quais se estabeleciam diferentes parâmetros de ocupação urbana. Desde os anos 30, com a introdução das ideias e práticas de Luis Anhaia Mello no setor de urbanismo paulistano, o zoneamento se tornara um consenso como instrumento de planejamento. Todavia, segundo Sarah Feldman (2005), existiram nas primeiras décadas do século XX duas experiências de utilização do zoneamento como instrumento de planejamento com resultados bem diversos.

Nos anos de 1920, tanto a Alemanha quanto os Estados Unidos irão lançar mão zoneamento, entretanto, na Alemanha ele será mais utilizado como método de organizar a cidade sob o ponto de vista técnico/estrutural, sobretudo, buscando solucionar questões sociais. Tal é o principal motivo de sua incorporação na concepção das siedlungen - bairros residenciais para classes populares construídos pelo poder público.

Projetadas por arquitetos de renome como Ernst May, Bruno Taut, Martin Wagner, no âmbito de administrações das cidades social-democratas, elas representam a experimentacõo dos princípios do zoneamento projetual, na busca da estandartização construtiva. As siedlungen são experiências que consubstanciam, segundo Tafuri (1975:81), um modelo de intervenção baseado na ideologia anti-urbana com objetivos sociais. Uma exeriência que, segundo o autor, coloca como "um oásis de ordem, um exemplo de como se torna possivel, através da organização da classe operária, propor um modelo alternativo de desenvolvimento urbano, uma utopia realizada". A utiização do zoneamento na Alemanha se vincula, nestes casos, à perspectiva de realização da cidade eficiente, bela e ordenada, perdendo seu peso enquanto instrumento de controle do preço do solo. É utilizado apenas em seus

construção: uma trajetória profissional no processo de institucionalização do urbanismo no Brasil (1926-1965/1966). Tese (doutorado). Unicamp. IFCH. Campinas. 2007. 
aspectos funcionais, como organizador das atividades urbanas: controle de densidade, circulação de ar e luq, e melhoria de tipologias habitacionais. Essas experiências, do ponto de vista urbanistico, não foram bem sucedidas quando os projetos levaram os principios do zoneamento às últimas consequências, e as siedlungen se configuraram como áreas estritamente residenciais, distantes do centro e desprovidas de serviços. (FELDMAN: 2005: 112)

A experiência da incorporação do zoneamento no planejamento local e regional nos Estados Unidos assume características bem diversas da Alemanha. Nos EUA, o zoneamento é utilizado sobretudo para atender aos interesses da valorização imobiliária e o seu resultado é a geração de cidades ainda mais segregadas e fragmentadas. O zoneamento, neste caso, é utilizado basicamente para protejer as construções residênciais e os valores do solo das intromissões prejudiciais de outras classes sociais, a sua adesão, inclusive, não acontece apenas entre urbanistas mas também entre empresários do setor de construção, proprietários de terras, comerciantes e políticos. O zaneamento estadunidense estaria mais proximo do que Paulo C. G. Marins (1998) classificou como um mal cofessado projeto de homogenização de vizinhanças entre as elites das cidades brasileiras.

Embora Sarah Feldman (2005) aponte que o planejamento urbano da cidade de São Paulo tenha sido influenciado principalmente pelo modelo dos Estados Unidos, não é possível identificar com precisão a influência urbanística na elaboração do Plano Diretor de Ribeirão Preto, se alemã ou estadunidense. Todavia, o jornal que noticiara a contratação do urbanista José de Oliveira Reis apresenta as projeções da transformações urbanísticas da cidade da seguinte maneira:

No projeto, evitam-se as grandes despesas com desapropriações, o que oneraria, de muito $e$ demandaria maior tempo, a execução do grande empreendimento.

Entretanto, em alguns pontos, são profundas as modificações na fisionomia da cidade: mudança da atual estação da Mogiana, para traz do local onde está localizado o campo do Botafogo Futebol Clube, ou seja cerca de 900 metros do lugar atual; prolongamento e consequente alargamento da rua General Osório até a nova estação, rasgando, destarte, uma nova avenida que, implicitamente amplia a zona urbana da cidade, absorvendo a Vila Tibério - alargamento da Avenida Saudade, prolongandose até a Avenida do Café o que lhe imprimirá um aspecto majestoso, sabendo-se que a largura dessa via pública é estimada no projeto em 12 metros; transformação do Cemitério Municipal em Parque Cemitério, sem os muros e com amplo ajardinamento dessa necrópole; retificação dos diversos córregos que margeiam a cidade.

Realça-se no Plano Diretor de José de Oliveira Reis uma tentativa de estender o eixo comercial da cidade até o interior do antigo bairro da Vila Tibério, o projeto de afastamento da estação ferroviária pelo menos em 900 metros para o interior do bairro, além da proposição de alargamento da rua General Osório até a futura estação de trens promoveria a valorização dessa região da cidade, que havia sido ocupada, principalmente, pelos operários das fábricas de cerveja instaladas na Avenida Jerônimo Gonçalves. Assim, o urbanista procurava inverter os vetores de valorização imobiliária da cidade.

A proposta de alargamento em 12 metros da Avenida Saudade no sentido de um cemitério que existia no interior do bairro Campos Elíseos, a transforia num majestoso bulevar, levando a um futuro Parque Público organizado após a retirada dos muros do cemitério. Assim, o urbanista demonstra a intenção de privilegiar estes bairros mais antigos da cidade, que possuíam uma ocupação popular, além de terem sido bastante desfavorecidos durante as obras de melhoramentos sanitários da Primeira República. Dessa maneira, José de Oliveira Reis procurava quebrar a fronteira material 


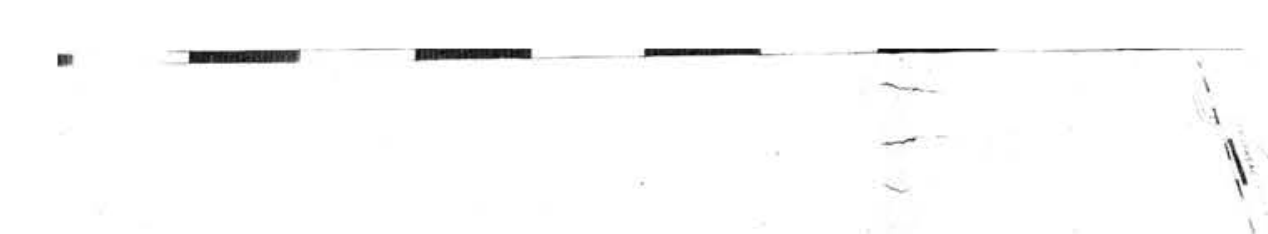

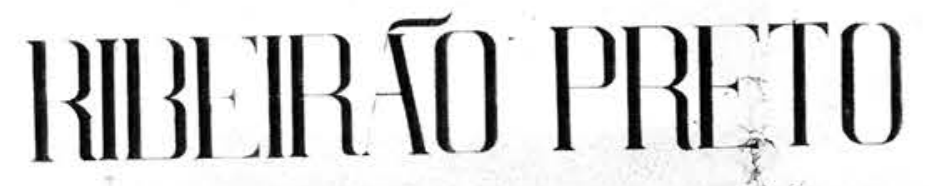

- HAPI GEIRHL

PIEFETTULA IUNCIPAL.

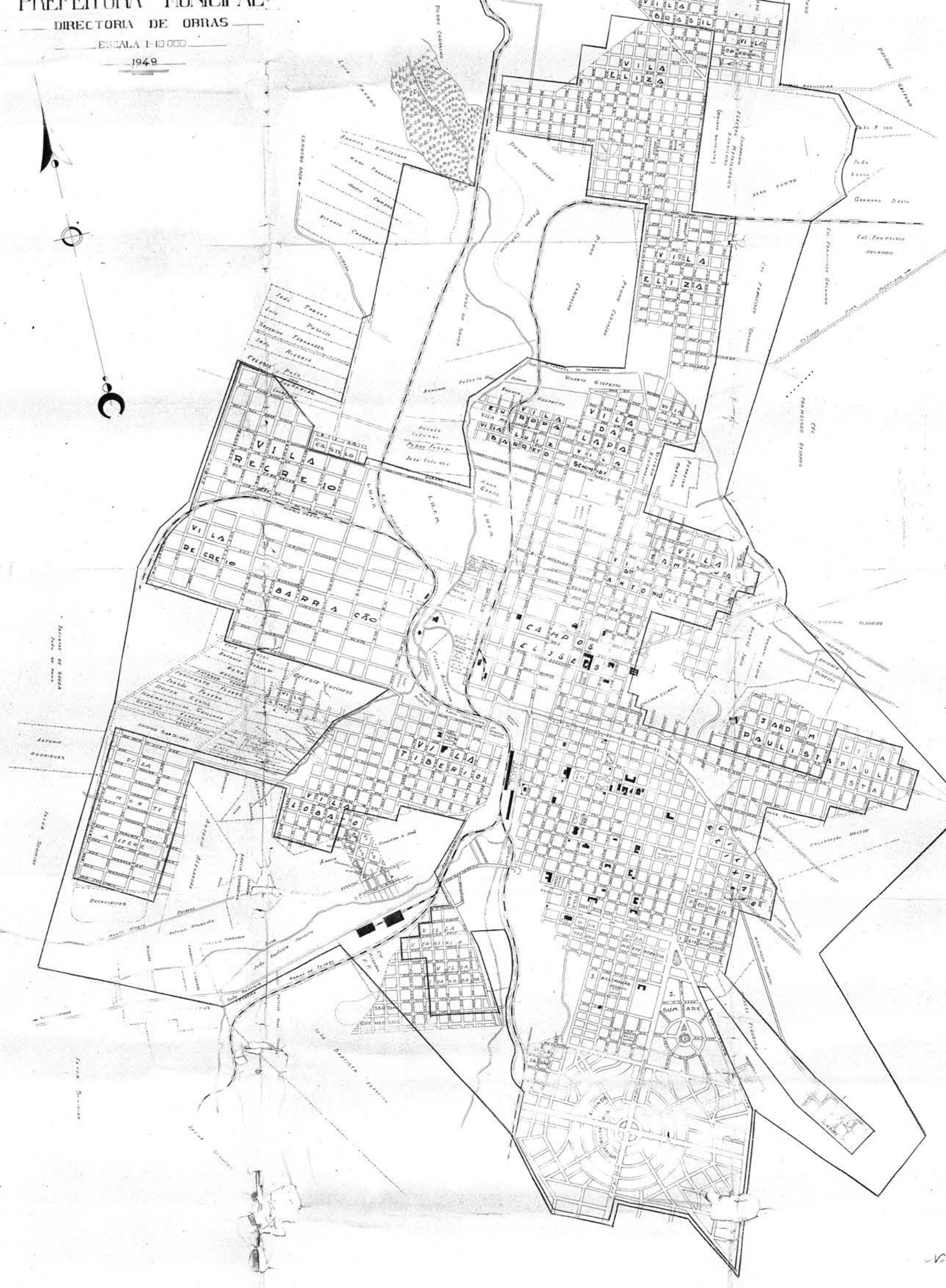

mate 
e social estabelecida pelos córregos dos rios que demarcavam o perímetro central, modificando de certa maneira a forma urbana que a cidade adquirira até a ocasião. ${ }^{1}$

Nas Observações e notas explicativas do esquema do plano diretor de Ribeirão Preto ${ }^{2}$, o urbanista justifica por razões econômicas e financeiras a manutenção quase sem alterações da parte da cidade existente com a exceção da modificação da localização de fábricas e da Estação de Ferro da Cia. Mogiana:

Devido a razões de ordem econômica e financeira, foi mantido quase sem alteração a parte atual existente da cidade. A modificaşão fundamental, entretanto, é a que se refere à localização da nova Estação da E. F. Mogiana, consequentemente das novas linhas, desvios, pateos, etc, atingindo principalmente os altos da Vila Tibério e do Barracão. Também em consequência dessa mudança das linhas da estrada de ferro, surgin a urbanização das áreas resultantes da desocupação das linhas atuais. (...)

Ribeirão Preto, na década de 1940, se tornara uma cidade com quase 80 mil habitantes, sendo por volta de 50 mil residentes na parte urbana do município. Nessa década ocorre justamente a virada de seu processo de urbanização, quando sua população urbana ultrapassa a rural. Desse modo, o Plano Diretor de José de Oliveira Reis não pretendia modificar as construções urbanas realizadas até o momento ou propor grandes demolições e deslocamentos populacionais como nos planos de reformas realizados durante a Primeira República. O seu objetivo era, principalmente, estabelecer uma organização esquemática do crescimento futuro da cidade.

O Plano Diretor cuida de preferência da extensão progressiva da cidade à medida do seu desenvolvimento. Trata, antes de mais nada, de prevenir o crescimento ordenado, dentro de um programa preestabelecido, em vez de deixá-lo livre, ao sabor dos interesses particulares isolados, de difícil e antieconômica solução posterior.

Para isso, Reis distingue, basicamente, duas grandes áreas na cidade: uma primeira área urbana, ou seja, a cidade propriamente dita, incluindo a área ocupada na década de 1940, e outra área onde aconteceria sua futura extensão. Após os limites desse perímetro urbano, o urbanista estabelece um cinturão agrícola abraçando a cidade, para o qual Reis alegava ainda a falta de um plano de extensão regional que poderia ser objeto de estudos posteriores.

No plano distinguem-se duas grandes áreas: $1^{a}$ área urbana, da cidade propriamente dita, incluindo a área atual e da futura extensão; $2^{a}$ área agrícola ou rural que também poder-se-ia chamar de suburbana. Para esta última não foi feito plano de extensão regional que embora necessário, poderá ser objeto de estudos posteriores, baseados nos elementos levantados em todo o município.

Ao voltar ao município em 1955 para proferir a palestra "O urbanismo e a sua influência no município"’, Reis reafirma a necessidade da elaboração de um planejamento regional para a região de Ribeirão Preto, explicitando novas influências urbanísticas nos anos 40, que o levou a pensar sobre planos não mais restritos ao espaço estrito dos núcleos urbanos como havia se caracterizado as elaborações de planejamento urbano do início do século XX. Assim, Oliveira Reis diria da tribuna da Câmara Municipal:

1 Uma divisão entre a cidade pobre - ao norte - e a cidade rica - ao sul.

2 A transcrição integral do projeto do Plano Diretor está no anexo da dissertação, e ele se encontra no acervo do Arquivo Público e Histórico de Ribeirão Preto.

3 Também transcrita integralmente em anexo. 
e social estabelecida pelos córregos dos rios que demarcavam o perímetro central, modificando de certa maneira a forma urbana que a cidade adquirira até a ocasião. ${ }^{45}$

Nas Observacõoes e notas explicativas do esquema do plano diretor de Ribeirão Preto ${ }^{46}$, o urbanista justifica por razões econômicas e financeiras a manutenção quase sem alterações da parte da cidade existente com a exceção da modificação da localização de fábricas e da Estação de Ferro da Cia. Mogiana:

Devido a razões de ordem econômica e financeira, foi mantido quase sem alteração a parte atual existente da cidade. A modificaşão fundamental, entretanto, é a que se refere à localização da nova Estação da E. F. Mogiana, consequentemente das novas linhas, desvios, pateos, etc, atingindo principalmente os altos da Vila Tibério e do Barracão. Também em consequência dessa mudança das linhas da estrada de ferro, surgin a urbanização das áreas resultantes da desocupação das linhas atuais. (...)

Ribeirão Preto, na década de 1940, se tornara uma cidade com quase 80 mil habitantes, sendo por volta de 50 mil residentes na parte urbana do município. Nessa década ocorre justamente a virada de seu processo de urbanização, quando sua população urbana ultrapassa a rural. Desse modo, o Plano Diretor de José de Oliveira Reis não pretendia modificar as construções urbanas realizadas até o momento ou propor grandes demolições e deslocamentos populacionais como nos planos de reformas realizados durante a Primeira República. O seu objetivo era, principalmente, estabelecer uma organização esquemática do crescimento futuro da cidade.

O Plano Diretor cuida de preferência da extensão progressiva da cidade à medida do seu desenvolvimento. Trata, antes de mais nada, de prevenir o crescimento ordenado, dentro de um programa preestabelecido, em vez de deixá-lo livre, ao sabor dos interesses particulares isolados, de difícil e antieconômica solução posterior.

Para isso, Reis distingue, basicamente, duas grandes áreas na cidade: uma primeira área urbana, ou seja, a cidade propriamente dita, incluindo a área ocupada na década de 1940, e outra área onde aconteceria sua futura extensão. Após os limites desse perímetro urbano, o urbanista estabelece um cinturão agrícola abraçando a cidade, para o qual Reis alegava ainda a falta de um plano de extensão regional que poderia ser objeto de estudos posteriores.

No plano distinguem-se duas grandes áreas: $1^{a}$ área urbana, da cidade propriamente dita, incluindo a área atual e da futura extensão; $2^{a}$ área agrícola ou rural que também poder-se-ia chamar de suburbana. Para esta última não foi feito plano de extensão regional que embora necessário, poderá ser objeto de estudos posteriores, baseados nos elementos levantados em todo o municipio.

Ao voltar ao município em 1955 para proferir a palestra "O urbanismo e a sua influência no município' ${ }^{\text {'t7 }}$, Reis reafirma a necessidade da elaboração de um planejamento regional para a região de Ribeirão Preto, explicitando novas influências urbanísticas nos anos 40, que o levou a pensar sobre planos não mais restritos ao espaço estrito dos núcleos urbanos como havia se caracterizado as elaborações de planejamento urbano do início do século XX. Assim, Oliveira Reis diria da tribuna da Câmara Municipal:

45 Uma divisão entre a cidade pobre - ao norte - e a cidade rica - ao sul.

46 A transcrição integral do projeto do Plano Diretor está no anexo da dissertação, e ele se encontra no acervo do Arquivo Público e Histórico de Ribeirão Preto.

47 Também transcrita integralmente em anexo. 
É insofismável que Ribeirão Preto é uma cidade progressista e como seu título de "Capital do Oeste de S. Paulo", vae vencendo inúmeras dificuldades e ultrapassando todas as expectativas.

O seu desenvolvimento, a sua expansão não podem ser feitos a mercê das improvisações indiscriminadamente. É preciso controlá-los. Já é tempo, pois, de dotar a cidade de um plano de melhoramento e expansão e ainda mais, atendendo às altas responsabilidades de cidade pioneira e cultural, dotar o Município de um Plano Regional, abrangendo não só o Plano Diretor da área urbana da cidade como também a zona rural e regiões limitrofes, interessando os Municípios vizinhos de Jardinópolis, Sertãozinho, Brodósqui, Guariba, Araraquara, Rincão, S. Simão, Cravinhos e Serrana, para apenas citar os que confirmam diretamente com os limites administrativos do Município de Ribeirão Preto. (REIS: 1955: 6)

O Mapa 12 demonstra o perímetro urbano sobre o qual José de Oliveira Reis se debruçou para elaborar o seu Plano Diretor em 1945. Nele se vê a linha férrea dividindo a cidade de leste a oeste, alvo de uma proposta de reposicionamento do urbanista. Outro detalhe são os bairros com traçados circulares ao sul do mapa, que apesar de não terem sido implantados e, menos ainda, terem sido completamente ocupados na década de 1940, já aparecem desenhados nessa planta. Nela se vê, além da demarcação dos proprietários das glebas de terras do perímetro urbano, a extensão que a Zona Norte da cidade já havia adquirido naquele momento, sendo possível mensurar a distância que os bairros da região norte vão adquirindo em relação ao centro da cidade - Vila Eliza; Vila Brasil e Vila Lapa. Em contrapartida, vemos os bairros residenciais da zona sul da cidade serem implantados bastante próximos ao centro de Ribeirão Preto - Jardim Sumaré, Jardim Aclimação e a então Cidade Universitária, futuro Alto da Boa Vista. A distância dessas regiões relativamente ao centro de Ribeirão Preto definiria a valorização imobiliária de suas moradias, além do nível de melhoramentos urbanos de tais bairros.

Para a área urbana já consolidada na década de 1940, o Plano Diretor estrutura um sistema viário, basicamente, composto por avenidas radiais e perimetrais. Através dele é possível enxergar a leitura da cidade que José de Oliveira Reis realiza se baseando num sistema hierárquico de vias. O urbanista estabelece as vias de circulação externa de contorno do núcleo urbano até então existente, definindo a fronteira entre o cinturão agrícola. As vias de circulação interna serviriam para facilitar o tráfego em diversas direções no interior do perímetro urbano, sendo possível notar, além delas, diversas outras ruas de acesso residencial cuja baixa circulação de veículos é assegurada pelos cul-desacs ou mesmo pela própria gradação de larguras entre as vias de diferentes categorias:

Em planta separada, acham-se assinaladas as principais artérias de tráfego que definem a estrutura do plano diretor. São as seguintes: Avenida 9 de julho, independência, do Café e Jerônimo Gonçalves, formando o perímetro interno de irradiação da cidade propriamente dita. A perimetral exterior é como se segue: partindo do pontilhão da estrada do guatapará sobre as linhas férreas segue pelo leito atual da Mogiana até encontrar o Ribeirão Preto e dai pela Estrada de Sertãozinho ou pelo Parkway em direção ao Monte Alegre, atingi-se o alto da Vila Tibério que será cortada por uma nova avenida em diagonal até atingir novamente o Ribeirão Preto, pelo curso deste segue o parkway até o córrego do Tanquinho e por este último em direção a nascente, chega-se ao prolongamente da Avenida Independência, no cruzamento desta com o Morro do Cipó; contornando ainda pelas divisas do perímetro urbano com a zona agrícola, chega-se finalmente ao ponto de partida na estrada do Guatapará, no pontilhão do Emboaba. (REIS: 1945: 2-3)

O perímetro interno de irradiação da cidade se compunha, dessa forma, pelas quatro avenidas que a Câmara Municipal, através da atuação dos Intendentes durante a Primeira República, 
havia despendido enorme quantidade de dinheiro para construir. Além das avenidas de fundo de vales acompanhando os dois córregos centrais, Reis define a Avenida Nove de Julho para fechar o perímetro no seu lado sul. Construída para comemorar o centenário da independência, as desapropriações dos terrenos para sua implantação haviam consumido bastante o tesouro da Câmara Municipal.

Já na perimetral exterior, o urbanista começa a criar novas vias e caminhos para abraçar a cidade, essa perimetral é desenhada por espaços praticamente livres, que se encontravam fora do perímetro do núcleo urbano de ocupação mais antiga. Portanto, suas vias de circulação se iniciavam num pontilhão sobre a antiga estrada para a Fazenda Guatapará, num acesso constituído por Martinho Prado Junior ainda ao final do século XIX, e seguiam com o intuito de abraçar a cidade através dos Parkways que José de Oliveira Reis desenha aproveitando as várzeas dos principais rios que se situavam no Perímetro Urbano. A cidade ganharia, assim, imensas faixas de parques lineares:

As transversais no sentido leste oeste são: Avenida Capitão Salomão, Avenida Pernambuco, Avenida Nova do Parque do Cemitério e do Aeroporto marginando a estrada de Ferro S. Paulo Minas; no sentido norte sul as longitudinais mais importantes são: Avenida Independência, Avenida Saudade- Saldanba Marinho, prolongamento e alargamento de ambos os extremos da rua Castro Alves e finalmente, as marginais às linhas da Estrada de Ferro Mogiana.

Partindo do pontilhão da estrada do guatapará sobre as linhas férreas segue pelo leito atual da Mogiana até encontrar o Ribeirão Preto, pelo curso deste segue o parkway até o córrego do Tanquinho e por este último em direção a nascente, chega-se ao prolongamento da Avenida Independência, no cruzamento desta com o Morro do Cipó; contornando ainda pelas divisas do perímetro urbano com a zona agrícola, chega-se finalmente ao ponto de partida na estrada do Guatapará, no pontilhão do Emboaba. (REIS: 1945: 2)

O ponto 9 do esquema do Plano Diretor elaborado por José de Oliveira Reis seria uma das linhas de projeção de maior impacto no desenho urbano de Ribeirão Preto, alterando bastante a configuração da ocupação de muitos bairros da periferia da cidade. Além de proteger integralmente as várzeas dos rios urbanos que ainda estavam desocupadas na década de 1940 através da criação de uma rede de Parkways, a disposição de espaços livres florestados também nas intersecções de quadras e zonas de diferentes funções aumentaria exponencialmente a permeabilidade de áreas verde na cidade. Algo que traria um impacto enorme na amenização do clima urbano, além de potencializar a sobrevivência de pássaros, plantas e nascentes de água.

Cintura verde e espaço livre assinalam o tratamento que deverá ter as áreas intercaladas nas quadras, e das áreas ao longo dos córregos.

O reflorestamento das mesmas, com essência de várias naturezas, é destinado a crear não só a amenidade do clima, tão necessário a Ribeirão Preto, como constituir, também, uma reserva florestal de inestimável valor econômico.

Estas faixas de vegetação na zona de expansão da cidade e em geral ao longo das várzeas visam por outro lado, manter uniforme o regime dos rios, bem como fazer o saneamento da baixada, com o minimo de despesas. Esse reflorestamento, seja de eucaliptos, seja de qualquer outra essência de fácil obtenção e plantio poderá ser feito paulatinamente e com perseverança. No fim de poucos anos, com dispêndio suave a cidade ganhará uma grande área de vegetação protetora e amenizadora do clima, além do espaço para lazer e recreação, e riqueza patrimonial adquirida.

Preocupado com o grande número de construções e aprovações de loteamentos na cidade durante a década de 1940, Oliveira Reis propõe a aplicação do ponto 9 de seu projeto de Plano Diretor como prioritária. Nas décadas seguintes a cidade atravessaria um boom imobiliário, o que 


\title{
RIIBLIIRÃ() PPETYO
}

\author{
ESTADO IIE S. PAULO
}

\section{ESOUINA DO PLANO DIRETOR}

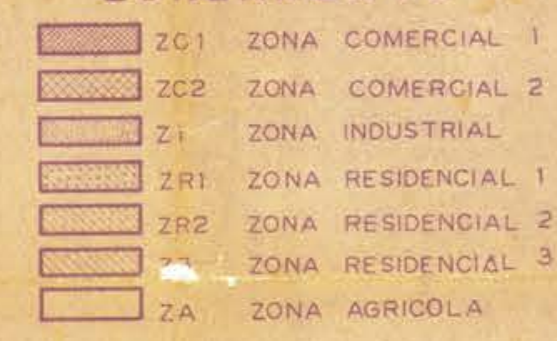

N

9

(1)
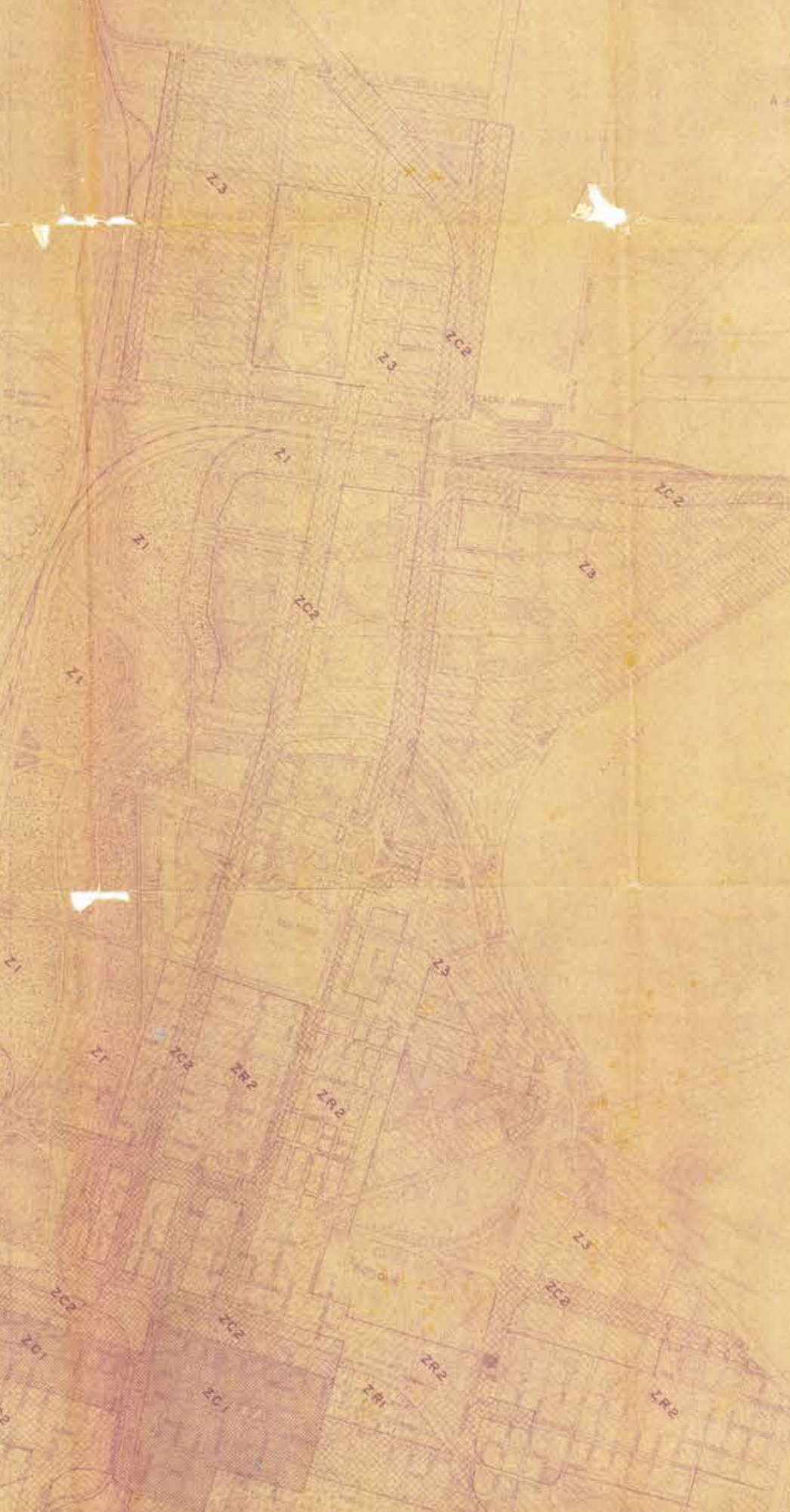

$\ln ^{2}$
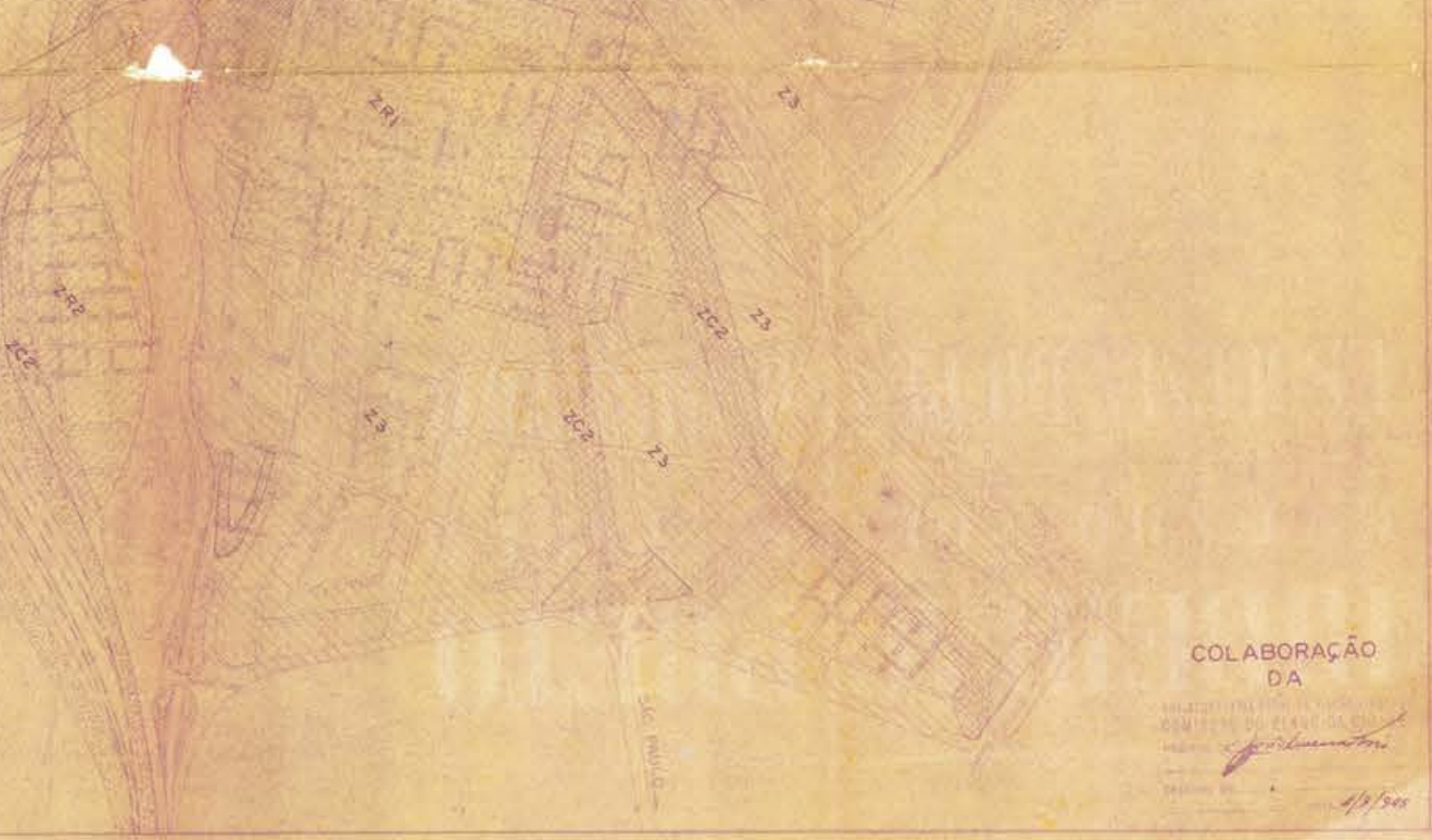


\section{PIBEIIRÃ() PPIET(O)}

ESTA DO IIE S. PAULO

\section{ESOIJMA IDO PLANO DIRETOR}
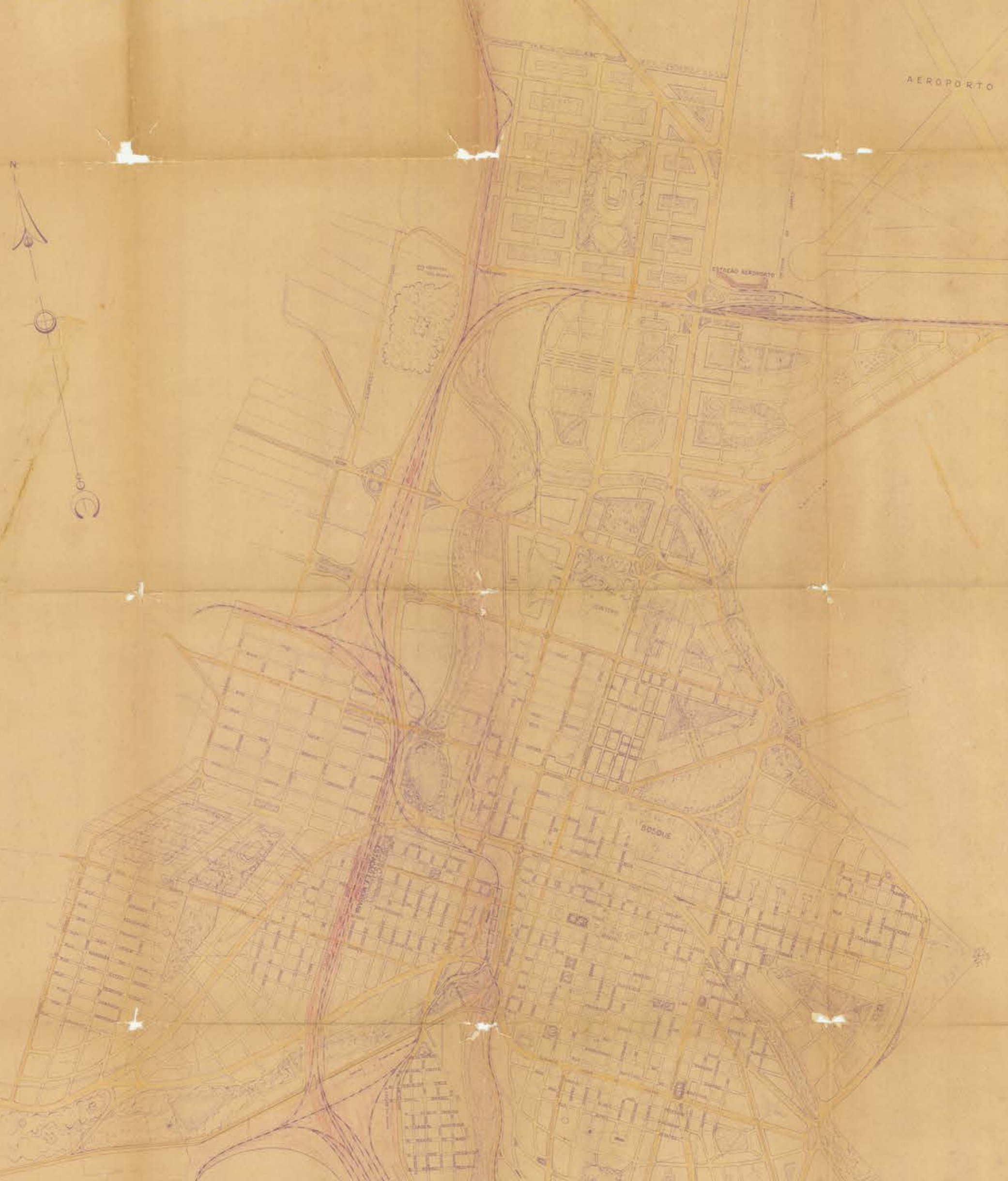
fazia daquele momento uma oportunidade única para estabelecer uma outra paisagem urbana para Ribeirão Preto. O vislumbre dessa situação fez Oliveira Reis demarcar o seguinte:

Seria, talvez, este um dos primeiros pontos do plano diretor a ser imediatamente estudado, analisado, para ser posto logo em execuscão.

Os espaços verdes ao longo dos rios permitirão a creação dos parkways que, além de facilitarem as ligaçoes de zonas, possibilitarão o estabelecimento de centros esportivos e de recreação no seu percurso, valorizando a região, tornando-a, além disso, mais atraente.Surgem, então, os parkways dos rios: Ribeirão Preto, Retiro, Tanquinho e República.

Dentro, ainda, do programa dos espaços verdes, encontra-se a área do bosque que foi aumentada de mais do triplo do atual. É que estando livre de qualquer loteamento, no momento atual, pode ser preservada para o seu reflorestamento e dada a sua proximidade do centro, poderá vir a ser um dos pontos de maior atração da cidade de Ribeirão Preto. (REIS: 1945: 4)

No esquema do Plano Diretor de José de Oliveira Reis transparecia, desse modo ,uma inspiração em Frederick Law Olmsted e nos seus sistemas de áreas livres florestadas, ligando diversos espaços verdes da cidade por meio de parques públicos urbanos. Algo que promovia uma aliança entre beleza e técnica no saneamento da cidade ${ }^{1}$. Entre os trabalhos de Olmsted em que pode ser constatada essa aliança está o Central Park de Nova York, onde se aproveita os reservatórios de abastecimento d'água para inserir uma imensa área verdes no miolo da ilha de Manhattan. A recuperação de áreas degradadas de Boston também é outra referência da construção de áreas verdes no interior de cidades, sendo um dos precursores do movimento City Beautiful, os parques de Olmested, além de resolverem problemas técnicos do crescimento urbano, seriam centros cívicos de convívio humano. ${ }^{2}$

José de Oliveira Reis estabelecia algo extremamente rico com essas faixas lineares de áreas livres florestadas. Além dos Parkways, o urbanista também definia outras zonas livres e públicas que teriam a função de conectar as Unidades de Vizinhanças, ou as zonas de diferentes ocupações estabelecidas no zoneamento do Plano Diretor. Tais elementos urbanísticos eram apresentados com a justificativa de compor na cidade áreas de vegetação para amenizar o clima de Ribeirão Preto, além de se tornarem espaços de lazer para a população.

No jornal que havia apresentado a remodelação de Ribeirão Preto aparece o seguinte sobre a constituição das áreas verdes em meio as Unidades de Vizinhanças:

Outra modificação curiosa do projeto e que se coaduna perfeitamente com a hora de velocidade que vivemos: os quarteirões da parte aumentada terão um minimo de 200 metros enquanto que as novas ruas e avenidas obedecerão a largura minima de 12 metros.

Em trono da área urbanizada, haverá uma faixa como uma cinta verde, ou seja a conservação das matas existentes ou o florestamento que as fizer preciso, como previdência necessária a de fechar a cidade contra o vento e as grandes tempestades.

O Bosque, a grande atração para os forasteiros que aqui aportam e também o ponto predileto para os passeios dos ribeiropretanos, será grandemente aumentado, estendendo-se os seus limites muito além, pelos terrenos do patrimônio municipal.

A "inta verde", não terá apenas a função de proteção contra os ventos, mas também a de manter o regime uniforme dos rios, o saneamento das baixadas e, em ultima análise, uma reserva florestal de

1 Faixas verdes lineares que se conectam cortando toda a cidade.

1 Ver SHENK, Luciana. Arquitetura da Paisagem: entre o Pinturesco, Olmested e o Moderno. Tese de Doutorado. EESC/USP, São Carlos, 2008. 
fazia daquele momento uma oportunidade única para estabelecer uma outra paisagem urbana para Ribeirão Preto. O vislumbre dessa situação fez Oliveira Reis demarcar o seguinte:

Seria, talvez, este um dos primeiros pontos do plano diretor a ser imediatamente estudado, analisado, para ser posto logo em execuscão.

Os espaços verdes ao longo dos rios permitirão a creação dos parkways que, além de facilitarem as ligações de zonas, possibilitarão o estabelecimento de centros esportivos e de recreação no seu percurso, valorizando a região, tornando-a, além disso, mais atraente.Surgem, então, os parkways dos rios: Ribeirão Preto, Retiro, Tanquinbo e República.

Dentro, ainda, do programa dos espaços verdes, encontra-se a área do bosque que foi aumentada de mais do triplo do atual. É que estando livre de qualquer loteamento, no momento atual, pode ser preservada para o seu reflorestamento e dada a sua proximidade do centro, poderá vir a ser um dos pontos de maior atração da cidade de Ribeirão Preto. (REIS: 1945: 4)

No esquema do Plano Diretor de José de Oliveira Reis transparecia, desse modo ,uma inspiração em Frederick Law Olmsted e nos seus sistemas de áreas livres florestadas, ligando diversos espaços verdes da cidade por meio de parques públicos urbanos. Algo que promovia uma aliança entre beleza e técnica no saneamento da cidade ${ }^{48}$. Entre os trabalhos de Olmsted em que pode ser constatada essa aliança está o Central Park de Nova York, onde se aproveita os reservatórios de abastecimento d'água para inserir uma imensa área verdes no miolo da ilha de Manhattan. A recuperação de áreas degradadas de Boston também é outra referência da construção de áreas verdes no interior de cidades, sendo um dos precursores do movimento City Beautiful, os parques de Olmested, além de resolverem problemas técnicos do crescimento urbano, seriam centros cívicos de convívio humano. ${ }^{49}$

José de Oliveira Reis estabelecia algo extremamente rico com essas faixas lineares de áreas livres florestadas. Além dos Parkways, o urbanista também definia outras zonas livres e públicas que teriam a função de conectar as Unidades de Vizinhanças, ou as zonas de diferentes ocupações estabelecidas no zoneamento do Plano Diretor. Tais elementos urbanísticos eram apresentados com a justificativa de compor na cidade áreas de vegetação para amenizar o clima de Ribeirão Preto, além de se tornarem espaços de lazer para a população.

No jornal que havia apresentado a remodelação de Ribeirão Preto aparece o seguinte sobre a constituição das áreas verdes em meio as Unidades de Vizinhanças:

Outra modificação curiosa do projeto e que se coaduna perfeitamente com a hora de velocidade que vivemos: os quarteirões da parte aumentada terão um minimo de 200 metros enquanto que as novas ruas e avenidas obedecerão a largura minima de 12 metros.

Em trono da área urbanizada, haverá uma faixa como uma cinta verde, ou seja a conservação das matas existentes ou o florestamento que as fizer preciso, como previdência necessária a de fechar a cidade contra o vento e as grandes tempestades.

O Bosque, a grande atração para os forasteiros que aqui aportam e também o ponto predileto para os passeios dos ribeiropretanos, será grandemente aumentado, estendendo-se os seus limites muito além, pelos terrenos do patrimônio municipal.

A "cinta verde", não terá apenas a função de proteção contra os ventos, mas também a de manter o regime uniforme dos rios, o saneamento das baixadas e, em ultima análise, uma reserva florestal de

48 Faixas verdes lineares que se conectam cortando toda a cidade.

48 Ver SHENK, Luciana. Arquitetura da Paisagem: entre o Pinturesco, Olmested e o Moderno. Tese de Doutorado. EESC/USP, São Carlos, 2008. 
grande valor quando não bastasse a propriedade que tem de concorrer para a amenidade do clima de nossa terra, que é tropical.

A parte alta da cidade historicamente ocupada por equipamentos salubres, como escolas, praças e clubes, mas que ainda não transpunha a Avenida 9 de Julho, acaba sendo definida no Plano Diretor como a Zona Residencial de $1^{a}$ Categoria. Partindo da divisão entre três categorias de moradias, José de Oliveira Reis define esta parte da cidade como uma área de residências mais valorizadas, o que consolidava o desenvolvimento histórico desses bairros como os de melhor padrão material na cidade. Entretanto, na região contígua à avenida que seria ocupada pelos futuros loteamentos da zona sul, o urbanista definia uma área livre que intercalaria duas Unidades de Vizinhanças distintas ou mesmo duas Zonas de ocupação diferentes.

Após dez anos, na palestra realizada na Câmara Municipal, Oliveira Reis atualizaria estes pontos da seguinte forma:

Hoje procurar-se-ia estabelecer um sistema de vias arteriais de caráter periférico as super quadras, dentro das quais seriam projetadas (Neighborbood Unit - Unité de Voisinage), cujas populacōes de 5 ou 6 mil habitantes gozariam das mais amplas vantagens que oferecem esses tipos celulares da cidade moderna. Por outro lado, o sistema de parques, espaços livres, áreas verdes, os parkways ao longo dos córregos e nas zonas baixas inundáveis e desvalorizadas deveriam ser objeto de seria cogitação da Municipalidade, pois o beneficio a economia, a salubridade que essas áreas proporcionam à população, justificam plenamente as despesas que a Prefeitura teria com a sua aquisição e transformação em parques. Nesse particular o esquema sugeriu providencias que se tivessem sido postas em pratica bá dez, anos não teríamos que lamentar, como agora, a sua falta. Além do cinturão verde preconizado no esquema ligado ao sistema de parques, bosques, etc, como aproveitamento do bosque exixtente e ampliando-o de cerca de 3 vezes, bem como o reflorestamento das várzeas dos córregos do Ribeirão Preto, Retiro, Tanquinho e República, havia a preocupação de dotar a área urbana de uma serie de pequenas praças e jardins de amenização tão necessárias a vida da cidade. (REIS: 1955: 8)

Nota-se uma linhagem conceitual que remonta às primeiras proposições de Unidades de Vizinhança $a^{50}$ nos EUA com os planos de Radburn em New Jersey, elaborados por Clarence Stein e Henry Wright, ou ainda no Regional Plan of New York. O conceito de Unidade de Vizinhança se referia a uma concepção urbanística que continha o provimento de habitações à população numa área cujo tamanho seria proporcional à densidade; uma limitação dessa área por ruas suficientemente largas para facilitar o tráfego; um sistema de pequenos parques e áreas de recreação planejada para encontros e necessidades particulares; locais para escolas e outras instituições, adequadas em espaços centrais da Unidade de Vizinhança; locais de comércio na junção das ruas de tráfego adjacente ao comércio de outra Unidade de Vizinhança; um sistema especial de ruas, desenhado em relação à carga de tráfego para facilitar a circulação interna e desencorajar o tráfego de passagem.

Esses elementos da urbanística de José de Oliveira Reis são identificados também na tentativa de aplicação de um zoneamento na cidade de São Paulo. Segundo Feldman (2005), eles possuíam mais uma vez a referência do community planning estadunidense, que era basicamente uma versão americana das ideias do inglês Ebenezer Howard. Os princípios básicos das cidades jardins eram a descentralização urbana, o limite do tamanho da cidade adequado ao equilíbrio agrícola-industrial e a definição de uma cinta verde para limitar a expansão da cidade. Nos EUA, a

50 Ver Faria, op. cit. 
Quadro 1: A evolução do zoneamento urbano de Ribeirão Preto. Fonte: SANCHES: 2003: 182.

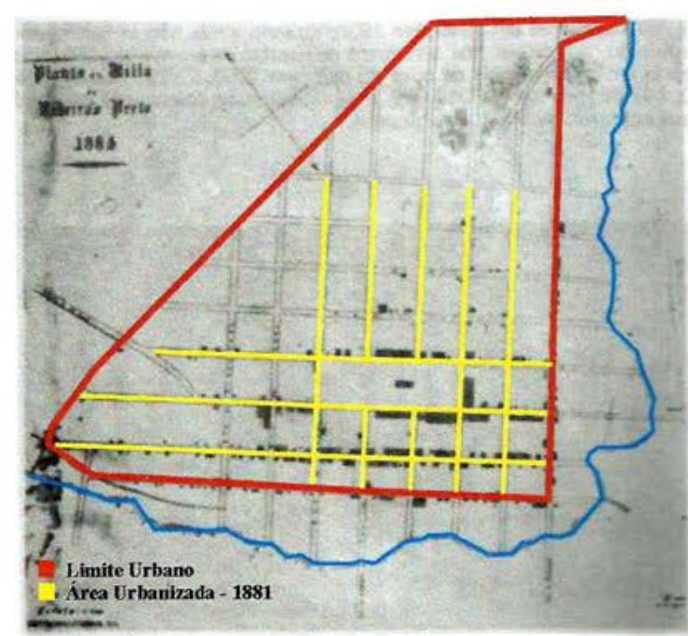

Figura 3.17.

Ribeirão Preto: Limite Urbano - 1881

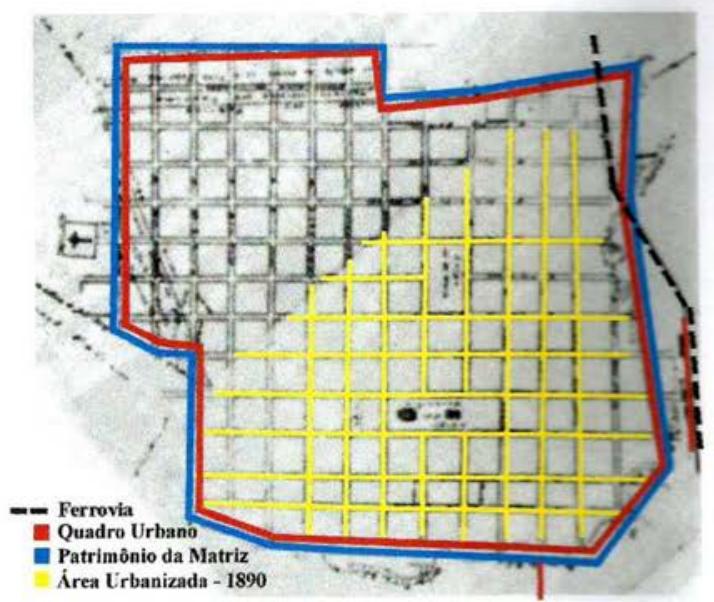

Figura 3.19.

Ribeirão Preto: Quadro Urbano - 1890

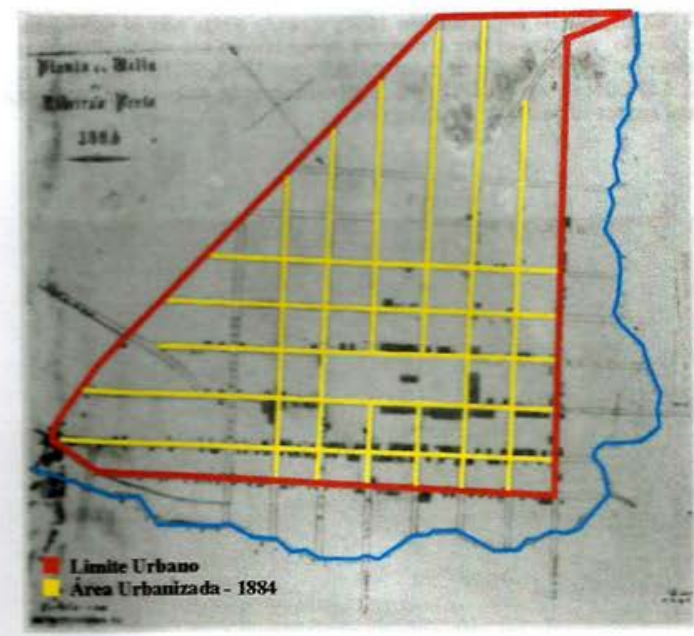

Figura 3.18.

Ribeirão Preto: Limite Urbano - 1884

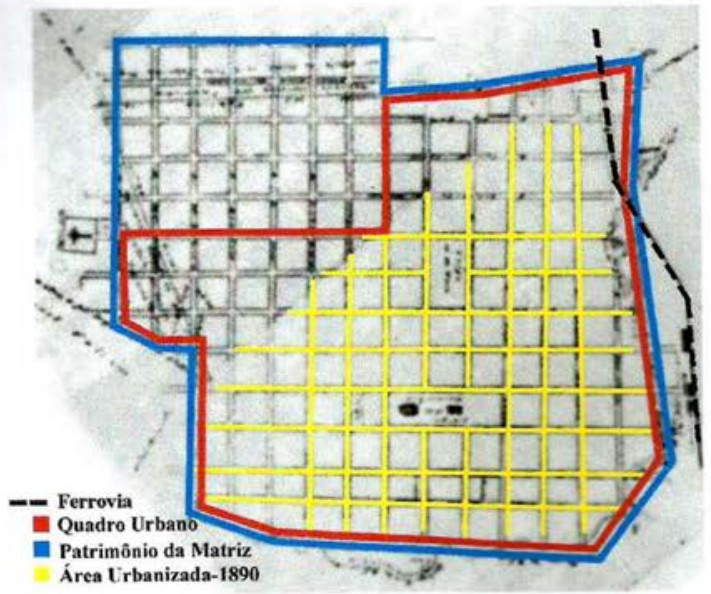

Figura 3.20.

Ribeirão Preto: Quadro Urbano - 1891

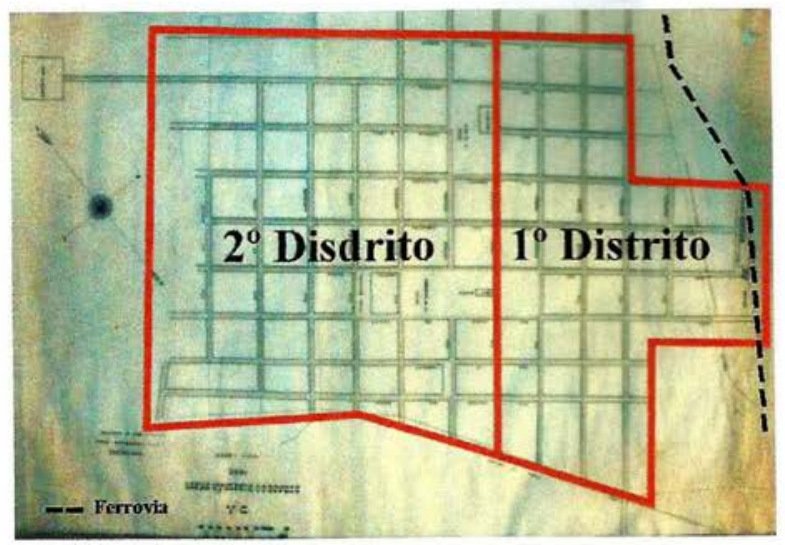

Figura 3.21.

Ribeirâo Preto: Criação do $1^{\circ}$ e $2^{\circ}$ Distrito Urbano -1891

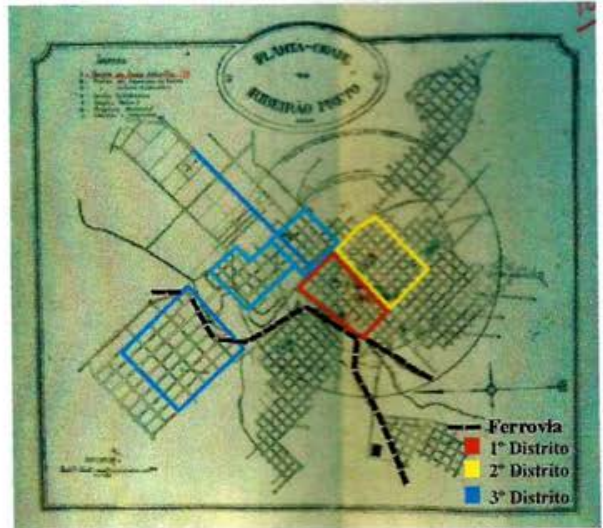

Figura 3.22.

Ribeirão Preto: Criação do $3^{\circ}$ Distrito Urbano -1897 
Quadro 2: A evolução do zoneamento urbano de Ribeirão Preto. Fonte: SANCHES: 2003: 183

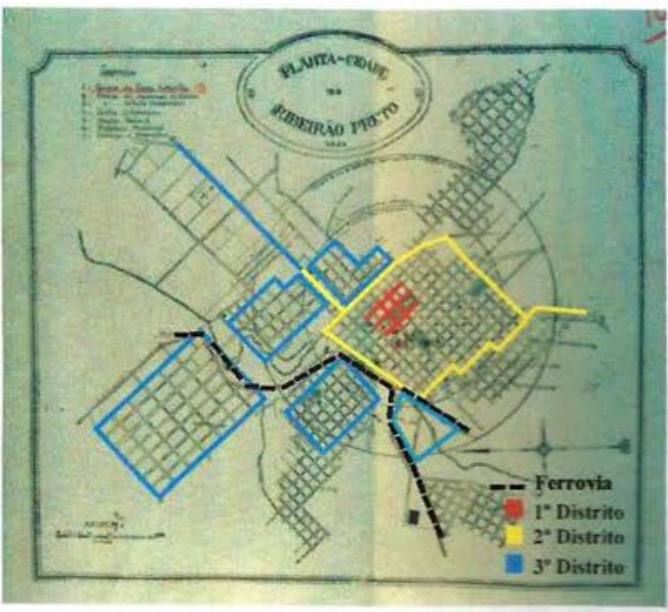

Figura 3.23.

Ribeirâo Preto: Limites $1^{a}, 2^{a}$ e $3^{a}$ Distrito - 1911

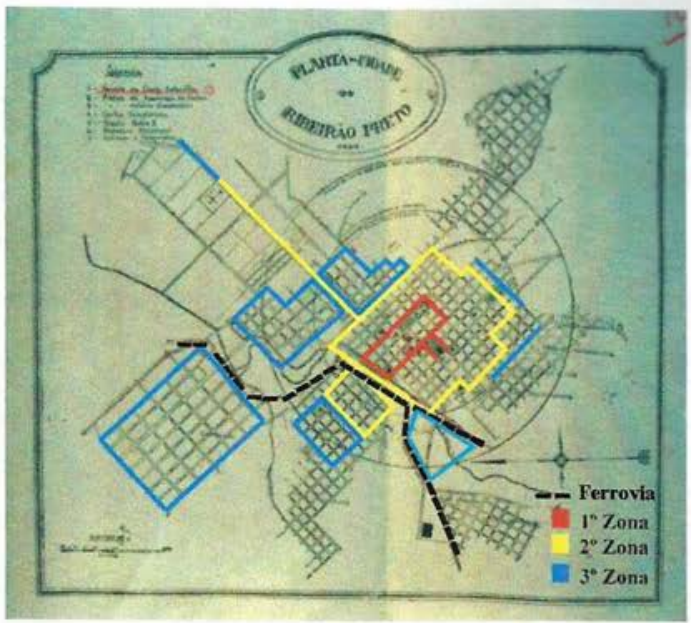

Figura 3.25.

Ribeirão Preto: Limites $1^{a}, 2^{a}$ e $3^{a}$ Zona -1920

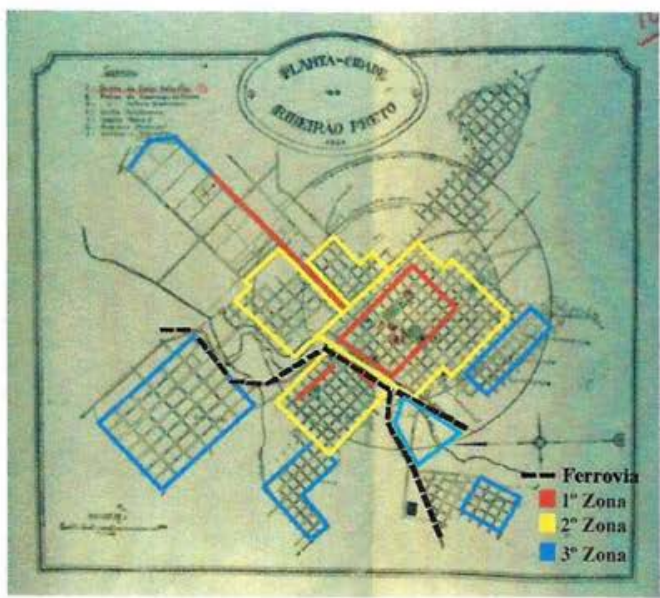

Figura 3.27.

Ribeirâo Preto: Limites $1^{a}, 2^{a}$ e $3^{a}$ Zona -1924

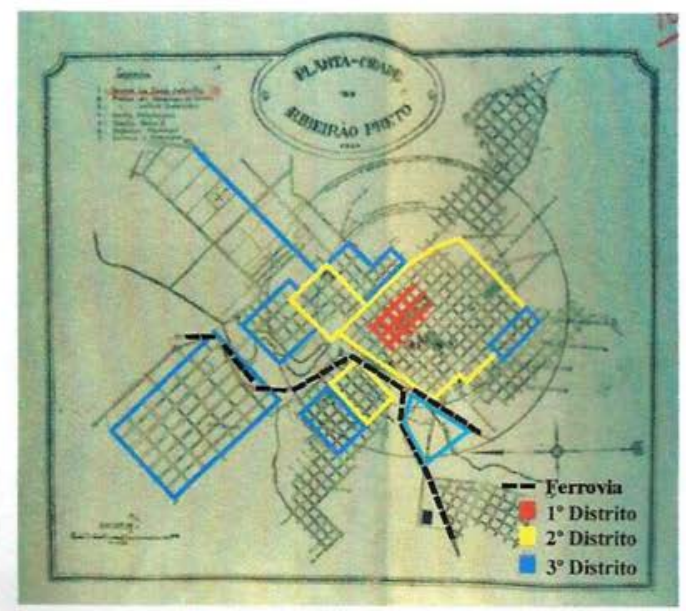

Figura 3.24.

Ribeirão Preto: Limites $1^{a}, 2^{a}$ e $3^{a}$ Distrito -1912

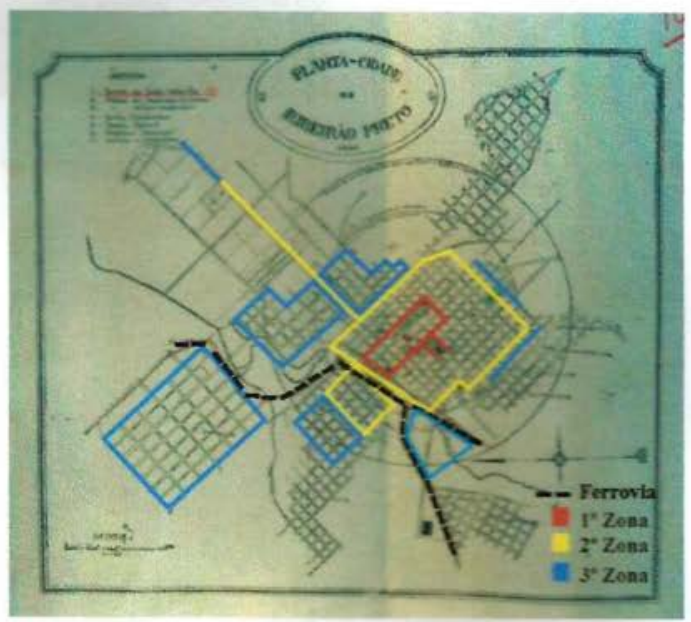

Figura 3.26.

Ribeirão Preto: Limites $1^{4}, 2^{\circ}$ e $3^{\circ}$ Zona - 1921

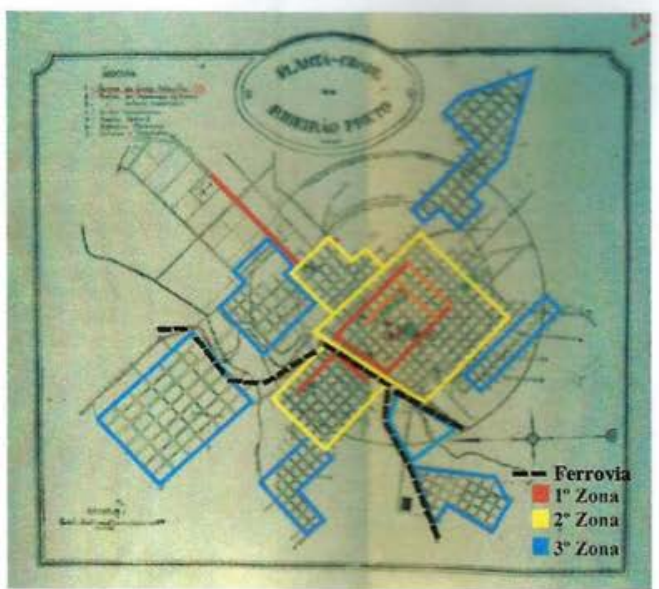

Figura 3.28.

Ribeirão Preto: Limites $1^{a}, 2^{a}$ e $3^{a}$ Zona -1925 


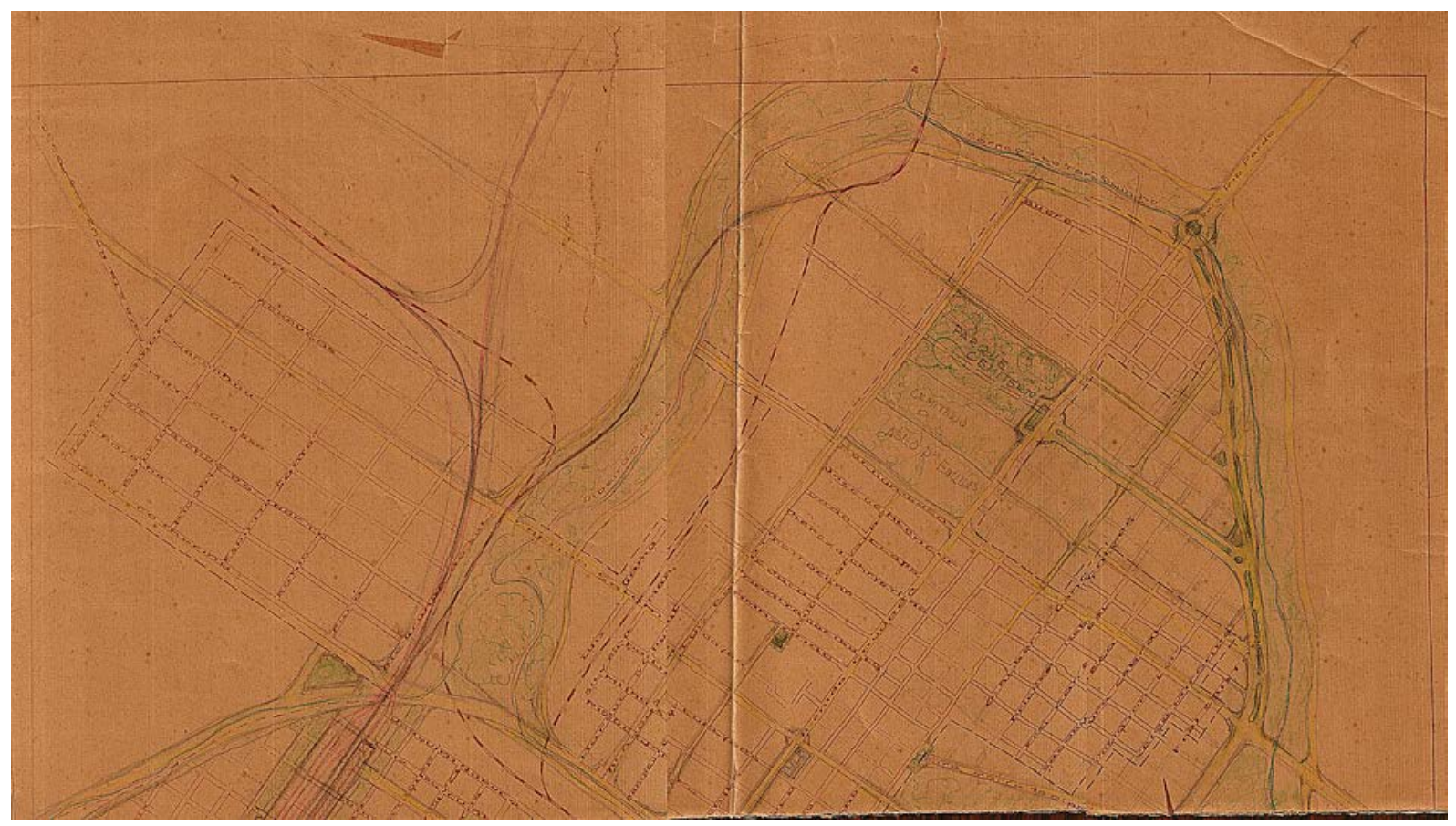

Mapa 16: os estudos feitos por Oliveira Reis sobre as plantas da cidade da década de 1940. Na zona norte da cidade destacasse o sistema de áreas livres (parkways) ao longo do rio Preto e do rio Tanquinho contornando o limite da ocupação urbana dessa região. Porém, as maiores áreas estabelecidas como Zonas Industriais no Plano Diretor serão desenhadas por Oliveira Reis nessa região. Fonte: APHRP.

partir dos anos 20, as propostas de unidade residenciais de baixa densidade passam ser valorizadas como uma forma lucrativa de investimento imobiliário. Logo, os princípios de Howard sobre a propriedade cooperativa do solo, autonomia econômica da comunidade e os cinturões agrícolas são abandonados e o modelo de bairros baseados no conceito de neighborbood unit cell ganha projeção.

Três urbanistas, recorrentemente citados pelos engenheiros e engenheiros-arquitetos paulistanos, tem papel fundamental na difusão e reinterpretação das ideias de Howard nos Estados Unidos: o inglês Thomas Adams, que no inicio de sua carreira foi membro da Garden City Association, entidade criada para difundir a ideia de cidade jardim, e nos anos de 1920 se vincula ao grupo do city planning americano descompromissado com questões sociais, e os americanos Clarence Perry e Clarence Stein. Perry desenvolve o conceito de neighborbooh unit cell, em 1924, quando propõe um esquema de organizaçãa criada em 1923, com forte atuação voltada para uma política pública de babitação social , desenvolve o projeto da cidade de Radburn. (FELDMAN: 2005: 125).

José Oliveira Reis, na palestra que profere na Câmara Municipal de Ribeirão Preto, também irá lançar mão da referência do urbanista estadunidense Thomas Adams numa tentativa de chamar a atenção aos vereadores da cidade sobre a importância do urbanismo como uma nova técnica de planejamento social:

A conceituação moderna de Urbanismo pode ser encontrada na definição de Thomaz. Adams urbanista americano - quando di:

"Urbanismo é a arte de planejar o desenvolvimento das cidades, com objetivo de assegurar saúde, segurança e condicões de trabalho aos seus habitantes, prevendo eficientes e convenientes formas de circulação e fomentando o bem estar geral".

Segundo Rodrigo Faria (2007), apesar dessa referência conceitual, o Plano Diretor de Ribeirão Preto remetia também ao Bairro do Peixoto em Copacabana, projetado por Oliveira Reis em 1938, antes de sua viagem aos Estados Unidos. Lá, ele realizara uma articulação entre áreas verdes e vias internas, além de um sistema viário rodeando o perímetro do bairro, que é construído 
quase como exceção em Copacabana como conjunto arquitetônico residencial uniforme.

Tanto o plano do Bairro do Peixoto quanto o plano de Ribeirão Preto, ambos trabalhos considerados de autoria pessoal, passando pelo plano de Vera Cruz (que foi um trabalho coletivo), estão pautados pelas determinações conceituais do que seria uma Unidade de Viz̨inhança (...). Chandigarh, Vera Cruz, Ribeirão Preto, Brasilia, entre outras realizacões são interlocuçōes relacionais que operam uma transformação inerente ao processo de circulação de conceitos, das ideias, das realizaçoes dos que trabalharam com a Unidade de Vižnhança; o próprio plano de Redburn deve representar uma transformação necessariamente resultante do processo interpretativo de seus autores - Clarence Stein e Henry Wright - sobre os conceitos elaborados para o Regional Plan of New York por Clarence Perry. (FARIA: 2007: 369)

Ainda segundo o mesmo autor, no caso do plano urbanístico que Oliveira Reis elabora para Vera Cruz, as Unidades de Vizinhança são limitadas por um contorno verde para ser ocupado com equipamentos educacionais, esportivos etc, definindo o limite da expansão urbana com a implantação de outras Unidades de Vizinhanças. Essa solução é diferente da elaborada no Plano Diretor de Ribeirão Preto, que utiliza a própria Unidade de Vizinhança como um elemento de contenção da expansão da cidade.

Olhando as plantas de José de Oliveira Reis, nota-se que a estruturação das avenidas perimetrais e radiais define duas coisas essenciais no seu Plano Diretor: o Cinturão Verde contornando a cidade e o sistema de áreas livres nos espaços que intercalam as quadras de futura ocupação, principalmente, nas faixas de vegetação ao longo dos córregos da cidade. Reis ainda propõe o reflorestamento dessas áreas com vegetação de várias naturezas, o que criaria não só a amenidade do clima, bastante importante para Ribeirão Preto, como também uma reserva florestal de grande valor econômico.

Por fim, o Plano Diretor estabelece o zoneamento da área urbana da seguinte forma:

Quanto ao zoneamento a área urbana foi dividida nas seguintes zonas:

- ZCI - Zona Comercial de $1^{a}$ categoria.

- ZC2- Zona Comercial de $2^{a}$ categoria.

- ZI - Zona Industrial.

- ZRI - Zona Residencial de $1^{a}$ categoria.

- ZR2- Zona Residencial de 2a categoria.

- ZR3-Zona Residencial de $3^{a}$ categoria.

- ZA - Zona Agrícola on Rural.

O código de obras deverá regulamentar o zoneamento. Além dessas zonas, poderáá haver núcleos de categorias diferentes situadas nas zonas de especificação diversa. A determinação desses núcleos dependerá de fatores indicados pelo desenvolvimento e tendências da cidade. Torna-se necessário uma revisão do atual código de posturas, adaptando-o as novas condições do plano. O Decreto 6.000 da Prefeitura do Distrito Federal poderá servir para orientação do novo código.(REIS: 1945: 5)

No zoneamento da cidade, é interessante notar que Oliveira Reis define como padrão a necessidade de se estabelecer a zona industrial em áreas de baixo preço, próximoa a linha férrea e afastada da zona residencial de $1^{\text {a }}$ categoria. Além disso, ela deveria estar distante do centro comercial e, finalmente, à jusante dos ventos dominante, o que garantiria, segundo o urbanista, a possibilidade de expansão futura da industrialização da cidade.

Desse modo, Reis acaba definindo como zona industrial de Ribeirão Preto uma região historicamente ocupada por fábricas, ou por bairros populares e operários. A zona industrial 
se situaria, principalmente, na zona norte da cidade, numa área que teve seu primeiro vetor de ocupação definido pelo Núcleo Colonial Antonio Prado ainda ao final do século XIX.

\section{Zona Industrial}

Qualquer cidade deve ter, como principio, a sua zona industrial perfeitamente definida com possibilidade de expansão futura em áreas de baixo preco, próximo a linhas férreas, afastada da zona industrial, não muito distante do centro comercial e finalmente a jusante dos ventos dominantes.

No caso de Ribeirão Preto, as características acima foram em parte observadas e pôde ser prevista com a regulamentação adequada em face do esquema do Plano Diretor. Localizou-se a zona industrial ao longo das linhas férreas e justamente nos bairros cujas tendências industriais são hoje manifestas. O zoneamento urbano da cidade de Ribeirão Preto não foi estabelecido pela primeira vez no Plano Diretor, mas vinha se consolidando desde as primeiras leis de uso e ocupação do solo criadas pela Câmara Municipal durante a Primeira República. Segundo Karla Sanches (2003), essas leis municipais eram estabelecidas, principalmente, para organizar a cobrança do Imposto Predial quando até 1895, a divisão do perímetro da cidade era feita em dois distritos. Todavia, após um despacho à Comissão de Contas da Câmara Municipal justificando a extensão do perímetro urbano ao bairro do Barracão é criado, em 1897, o terceiro Distrito Urbano da cidade, que também estaria sujeito às fiscalizações sobre edificação, alinhamento, arruamento e a cobrança do Imposto Predial.

Em 1911, a Lei Municipal no 178 passa a definir três distritos distintos para a cobrança do Imposto de Viação, cujo valor levaria em conta os melhoramentos existentes em cada um deles. Ou seja, o $1^{\circ}$ Distrito possuiria um imposto maior em virtude de incluir as ruas, praças e calçadas de paralelepípedos ou macadame; já o $2^{\circ}$ Distrito compreenderia as demais ruas sem pavimentação dentro do perímetro urbano que possuíssem iluminação e sarjetas; o terceiro Distrito incluiria as ruas e praças de bairros mais afastados do centro da cidade, que quase não possuíam melhoramentos urbanos, tendo a menor taxa do imposto.

Em 1920, a Lei Municipal no 246 modifica a nomenclatura dos Distritos, estabelecendo as $1^{\text {a }}, 2^{\text {a }}$ e $3^{\mathrm{a}}$ Zonas da cidade. Já em 1924, a Lei Municipal no 302 modifica as tabelas do Imposto de Viação, estabelecendo a Taxa de Localização de Oficinas. O Art. 16 estabelecia o seguinte:

Súnico - são isentas desta taxa as oficinas, garagens, fábricas ou máquinas industriais instaladas fora da $1^{\circ}$ e $2^{\circ}$ zona ou nas proximidades das estações de ferro. As que já funcionarem em qualquer zonas tem o prazo de dois anos para transferirem suas instalacões para fora desse perímetro, e se não fizerem passarão a pagar o dobro da referida taxa findo o prazo. $\left(3^{\circ}\right.$ Livro de Registro de Leis de Ribeirão Preto: Lei 302, p.1 apud SANCHES: 2003: 180)

A criação da taxa de localização de indústrias situadas na $1^{\mathrm{a}}$ e $2^{\mathrm{a}}$ Zonas demonstra a intenção da Câmara Municipal em promover a locomoção das fábricas para a $3^{a}$ Zona da cidade, que possuiria isenção dessa taxa de localização industrial. A adoção do Código de Obras Arthur Saboya, em 1933, irá restabelecer a divisão da cidade em quatro Zonas distintas. Desse modo, é possível estabelecer um diálogo entre o zoneamento elaborado por José de Oliveira Reis e a evolução das leis de ocupação que acompanharam o crescimento da cidade.

As razões funcionais e ecônomicas de se estabelecer a Zona Industrial em áreas de baixo preço e a jusante dos ventos dominantes consumaria a fragmentação social da cidade, uma vez 
que próximo a essa região José de Oliveira Reis define a localização dos bairros residenciais de $3^{\circ}$ categoria, destinados obviamente aos operários das fábricas já existentes ou de futuras instalações. Nesse proposta de zoneamento se ressalta a semelhança do que vinha sendo elaborado em São Paulo pelo Departamento de Urbanismo a partir de 1947. O controle do uso do solo vinha sendo demarcado através da discriminação de atvidades e volumes de contrução que eram ou não permitidas em cada zona da cidade. Essa classificação obedecia à divisão entre residência, comércio e indústria.

A primeira proposta de lei geral de zoneamento elaborada em São Paulo se baseou na legislação carioca de 1937, mas a partir de 1949 o modelo das leis americanas comeca a se adotado, principalmente, em relação à classificaşão de usos, por indicaç̧ões ninliográficas de Anhaia Mello. Nas propostas de 1952 e 1955, elaborads após a avaliação do projeto de lei de 1949 por Robert Moses, a influência americana se amplia e a referência mais evidente é a leipara Nova York entregue à City Planning Comission em 1950. O "Plan for Rezoning the City of New York" foi elaborado sob a responsabilidade de uma empresa de consultoria - Harrison, Ballard e Allen - que foi por uma extensa lista de "Technical Advisory Comittees": de arquitetura, estatísticas de emprego, engenharia, saúde, babitação, jurídico, estradas, comécio atacadista e varejista, armazenamento e setor imobiliário. Em relação à lei novaiorquina de 1916, a proposta de 1950 introduz várias inovaçoes que são absorvidas por Lefevre e andrade Filho. Em primeiro lugar, a própria estrutura de lei que, ao invés de definir três tipos de distritos - uso, altura e áreas - estabelece uma tipologia de zonas, a cada uma correspondendo um conjunto de parâmetros, tudo localizado em um só mapa utilizado conjuntamente a tabelas demonstrativas das condiçoes estabelecidas para cada zona, segundo usos. Em segundo lugar, adota os núcleos comerciais como categoria diretamente relacionada ao uso residencial, numa clara referência à unidade de vižinhança e, em terceiro lugar, adota o coeficiente de aproveitamento para controle do volume edificado. (FELDMAN: 2005: 133)

Na palestra que José de Oliviera Reis realiza na Câmara Municipal de Ribeirâo, ele enfatiza a criação de um Departamento de Urbanismo no município para regular o zoneamento que havia proposto no esquema do Plano Diretor. A intenção era a estruturação de um orgão com diversas seções técnicas no sentido de que se produzisse um volume de mapas, relatórios e estatísticas necessários a execução do Plano. Evidente também, como já apontado, a influência da concepção de Unidades de Vizinhanças para as três categorias de Zonas Residencias que são propostas no Plano. Assim, mesmo diante de uma hierarquia sócio-espacial entre as áreas de moradia na cidade, a ideia era que todas tivessem um outro tratamento urbanístico em sua implantação.

Ao final do Esquema do Plano Diretor, Reis escreveria:

concluindo, cabe mais uma vez frisar que o plano se apresenta como indicação visando metodizar o crescimento e expansão futura da cidade. Sua exequibilidade é viável dentro de um programa amplo, sadio e entusiástico, destinado às populações vindouras, como oferta da geração atual que com a melhor boa vontade, delinea, sugere, inicia e aspira, também, vê-lo realizado.

Rio de Janeiro, 4 de Setembro de 1945.

José de Oliveira Reis

Todavia, a penetração do urbanismo na esfera administrativa do município de Ribeirão Preto ocorre em meio às polêmicas e contradições de sua política local. Assim, após quase dez anos de sua elaboração, em 1954, o Plano Diretor entra em tramitação na Câmara Municipal, gerando uma forte divisão política entre os vereadores favoráveis à sua aprovação, que irão integrar a Comissão especial do Plano Diretor da Cidade, e àqueles contrários a delimitação do Plano como a lei fundamental do uso e ocupação do solo de Ribeirão Preto, que irão se arregimentar em torno do veto ao Plano realizado pelo prefeito municipal da UDN, José da Costa. Desse modo, se assiste 
na cidade às polêmicas a respeito da definição das diretrizes urbanísticas para o ordenamento de seu crescimento urbano.

Após àqueles dez anos da elaboração do esquema do Plano Diretor, José de Oliveira Reis, como já apontado, volta ao município para tratar das discussões na Câmara Municipal, sendo a ocasião em que o urbanista profere a palestra o Urbanismo e sua influência no Município. Antes da visita do urbanista, entretanto, é interessante notar que, em 1954, o projeto de lei no $10-54$, de autoria do vereador do PTB, Marques Ferreira, delimitava a Zona Residencial da cidade de Ribeirão Preto. Este projeto estruturava quatro abordagens sobre a zona, normalizando gabarito, casas geminadas, alinhamento, divisas de lotes, recuos, além de especificações sobre edifícios comerciais dentro da zona. Em pronunciamento na Tribuna da Câmara Municipal, o vereador Marques Ferreira advogava que o antigo Plano Diretor de 1945 fosse aprovado para orientar as construções que se avolumavam naquele momento sem nenhuma observância política. Porém, ele se fixa principalmente no projeto de lei que define a zona residencial da cidade, sendo importante sua demarcação, contendo normas especiais de construção, a fim de não prejudicar o urbanismo, como já se verificava, segundo o vereador, na Avenida 9 de Julho.

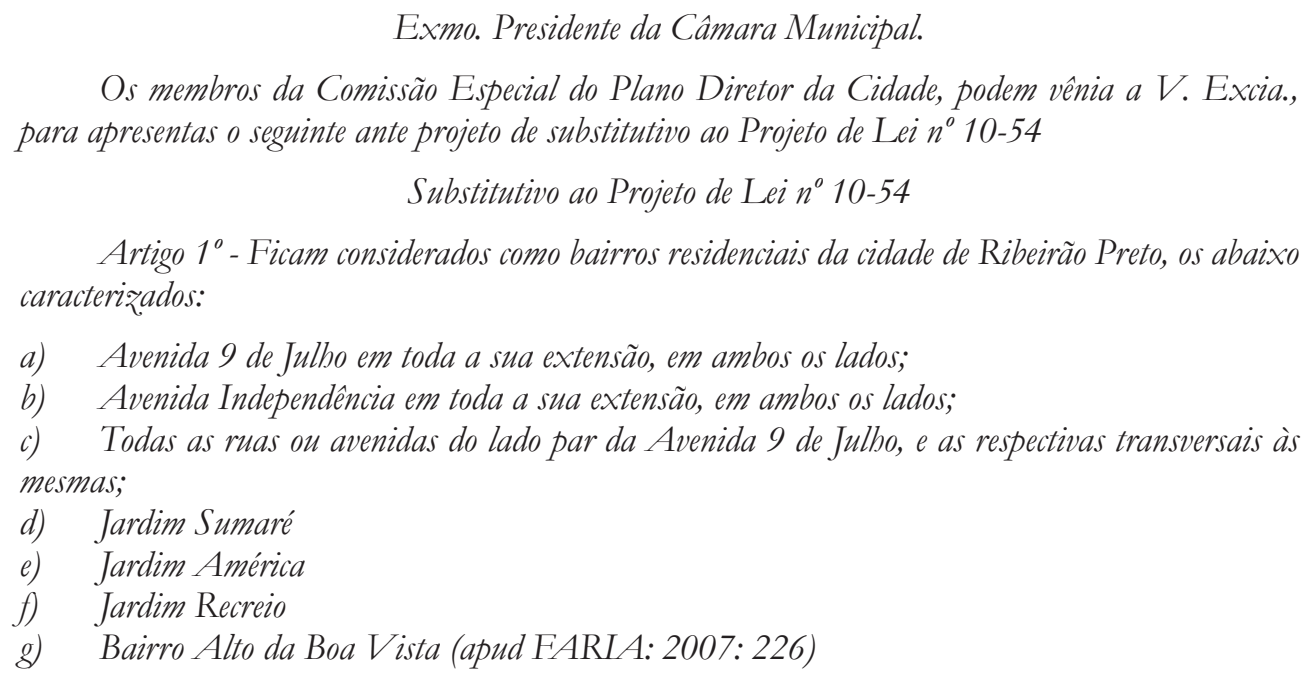
para apresentas o seguinte ante projeto de substitutivo ao Projeto de Lei n ${ }^{\circ}$ 10-54

Substitutivo ao Projeto de Lei n $n^{0} 10-54$

Artigo $1^{\circ}$ - Ficam considerados como bairros residenciais da cidade de Ribeirão Preto, os abaixo caracterizados:

a) Avenida 9 de Julho em toda a sua extensão, em ambos os lados;

b) Avenida Independência em toda a sua extensão, em ambos os lados;

c) Todas as ruas ou avenidas do lado par da Avenida 9 de Julho, e as respectivas transversais às mesmas;

d) Jardim Sumaré

e) Jardim América

f) Jardim Recreio

g) Bairro Alto da Boa Vista (apud FARIA: 2007: 226)

Nesse período, em 1955, a Câmara Municipal era dominada, basicamente, pelos vereadores do Partido Trabalhista Brasileiro, e o poder executivo, desde 1952, era ocupado por políticos mais conservadores alinhados à UDN. O prefeito interino, José da Costa, um imigrante mineiro que havia ascendido socialmente através de sua trajetória como um homem de negócios, tornando-se diretor de um amplo estabelecimento comercial, entrara na UDN de Ribeirão Preto através daquela estrutura montada pelo partido para conquistar capilaridade entre os bairros da cidade (ver tópico 3.3). Logo, José da Costa assumiria a prefeitura como interino após sua passagem como deputado estadual em 1948.

Em sua Palestra na Câmara Municipal, José de Oliveira Reis criticara em Ribeirão Preto, após dez anos de elaboração de seu Plano Diretor, a falta de organização da expansão da cidade, principalmente, em virtude da grande quantidade de loteamentos aprovados no decênio entre 1945-1955, pois a regulamentação desse tipo de ocupação era algo que já aparecia no Esquema do 
Plano Diretor :

As avenidas perimetrais externas, nos limites da cidade separando-a da zona agricola, foram delineadas para não só estabelecer o tráfego perimetral de intercomunicaşão de bairros, como fixar e definir de modo claro o limite do perímetro urbano. Somente dentro deste perímetro é que serão permitidas as divisões de áreas para arruamentos e loteamentos, obedecendo aos traçados do plano diretor. Alem dos limites do perimetro urbano não deverão ser permitidas aberturas de ruas e vendas de lotes. Este é um meio de impedir o crescimento desordenado e nocivo à comunidade. (REIS: 1945: 3)

Este assunto, desde o início das atividades legislativas da Câmara Municipal, no ano de 1955, movimentava as sessões plenárias e as atividades da Comissão Especial do Plano Diretor da Cidade, principalmente, no que se referia à aprovação do Projeto de Lei 19/1955, que iria suspender a regulamentação e liberação dos loteamentos para a conclusão e tramitação dos trabalhos do Plano Diretor.

$\mathrm{Na}$ Palestra, Oliveira Reis remeteria nesse assunto a importância da criação de um Departamento de Urbanismo no município de Ribeirão Preto para planejar a sua futura expansão:

Foi muito de propósito que escolbi o tema desta palestra para alertar no município a influência do urbanismo e procurar, ao mesmo tempo, fazer sentir a necessidade imperiosa de ser organizado quanto antes uma comissão ou um órgão técnico, ou departamento na municipalidade, para iniciar os estudos de planejamento do Municipio de Ribeirão Preto e, obviamente, da área urbana da cidade, a suburbana e a rural imediata, a fim de dotar este próspero município de um plano regional e de um plano diretor urbano que regulem o crescimento e expansão da cidade e município dentro das boas normas do Urbanismo. Esses estudos demandam tempo e perseverança. Estou certo, porém, que o patriotismo e os alevantados propósitos dos administradores e ilustres vereadores desta terra não deixarão passar mais tempo para que Ribeirão Preto possa oferecer mais esse exemplo de pioneirismo municipal de cidade progressista. (REIS: 1955: 7)

A proibição dos loteamentos pelo PL 19/55 foi objeto de uma acirrada divisão na Câmara Municipal por estabelecer no seu primeiro artigo o seguinte: "fica suspensa qualquer aprovação de loteamento até que estejam concluídos os trabalhos do Plano Diretor da cidade" (apud FARIA: 2007: 374). A prevenção de empreendimentos imobiliários em detrimento da organização urbanística da cidade demonstra uma preocupação de parte dos vereadores da Câmara Municipal com o crescimento urbano desordenado. Eis o polêmico texto da lei:

A Comissão do Plano Diretor da cidade de Ribeirão Preto, reunida em sessão, deliberou, por unanimidade, representar a Egrégia Câmara sobre o seguinte: a Comissão do Plano Diretor, já tendo iniciado os seus trabalhos, considera difícil, senão impossivel, a elaboração do mesmo plano, enquanto persistirem os sucessivos loteamentos de imóveis, por toda a periferia da cidade. Esses loteamentos - pelo menos os novos - deveriam ser suspensos temporariamente, ninguém pretende a extinção de tais negócios, mas o desenvolvimento do município exige a elaboração urgente de um plano diretor, objetivando fixar rumos para o futuro, corrigindo os defeitos do município, possibilitando um progresso ordenado através de processos ordenados e inteligentes (...) os loteamentos sucessivos, quase todos com finalidades exclusivamente lucrativas, retalhando em pedacinhos, grandes extensões de imóveis, devem ser suspensos, temporariamente, a fim de quando voltarem já encontrarem aprovado o plano diretor - que será um prejuizo para os loteadores (quatro on cinco pessoas) mas em beneficio dos cem mil babitantes atuais ou dos quinhentos on seiscentos mil no futuro. (...). Todavia, se fossemos examinar o aspecto legal do problema, tem-se a impressão de que bem duvidosa é a legalidade da aprovação, por parte da prefeitura, de tais loteamentos, quando situados em zonas rurais tributadas pelo Estado (apud FARIA: 2007: 375).

Diante desse projeto de Lei se inicia uma intensa disputa na Câmara Municipal a partir de abril de 1955. A Comissão de Justiça e Redação, presidida pelo vereador Álvaro Cardoso, com a presença do vereador petebista Marques Ferreira, presidente da Comissão Especial do Plano 
Diretor, apresenta ao plenário um requerimento clamando a urgência da tramitação do PL 19/55. A bancada do PTB na Câmara Municipal colocava esta lei como condição fundamental para a continuidade dos trabalhos da Comissão Especial do Plano Diretor da Cidade. O Projeto de Lei, ao passar pela Comissão de Justiça, num primeiro momento, é analisado pelo vereador Álvaro Cardoso positivamente, que alega não haver inconstitucionalidade na lei que suspenderia, a partir de dezembro de 1955, a aprovação de novos loteamentos na cidade. A aprovação do PL 19/55 era, portanto, de soberania do plenário.

No entanto, os integrantes da Comissão de Obras e Serviços Públicos da Câmara Municipal assumem posição contrária à Comissão de Justiça, apresentando obstáculos à lei em virtude da quantidade de loteamentos já aprovados, ou em andamento, assim como a localização deles. Uma emenda ao Projeto de Lei 19/55 é produzida por outro vereador da bancada petebista, Antonio Botelho, com o objetivo de desembaraçar a tramitação no plenário do Plano Diretor da Cidade. Porém, os loteamentos, cuja aprovação já estivesse sendo avaliada pela Prefeitura, seriam excluídos ao longo das discussões da proibição pautada pelo Projeto de Lei 19/55. Acabado o prazo regimental para as Comissões apresentarem seus pareceres, o Projeto de Lei 19/55 foi votado e aprovado em maio de 1955.

O texto final do Projeto de Lei 19/55, enviado ao prefeito udenista José Costa, passa então para a análise do Departamento Jurídico da Prefeitura Municipal. O seu diretor, vereador do PSD pertencente à oposição na Câmara, Alcides Sampaio, o mesmo político que recebera Oliveira Reis na prefeitura em 1944, e que agora ocupava o cargo de representante da OAB na Comissão Especial do Plano Diretor, apresenta um parecer desfavorável à suspensão da aprovação dos loteamentos. O veto do Prefeito udenista ao Projeto de Lei 19/55 ganha força e respaldo e não é mais derrubado na Câmara Municipal pela bancada petebista. Um consenso é criado com a dissidência de alguns vereadores da oposição pela alegação de que a competência de legislar sobre a propriedade privada, segundo a constituição federal, seria da União e não do município.

Após o veto ,se seguem intensos conflitos na Câmara Municipal. O vereador Álvaro Cardoso, presidente da Comissão de Justiça que havia sido favorável à suspensão dos loteamentos, solicita vistas e reuniões referentes ao veto municipal se pronunciando com o seguinte parecer:

Cumpre à Comissão de Justiça e Redação dar, neste parecer, sua interpretação sobre a legislação do veto aposto pelo Sr. Prefeito Municipal ao Projeto de Lei no 19-55 (...) Esta mesma Comissão ao dar parecer no projeto de lei que originou o veto, não viu nenhuma inconstitucionalidade e agora matem sua interpretação. Quanto ao parecer dado pelo sr. Consultor Jurídico da Prefeitura Municipal, única peça em que se baseou o Chefe do executivo para vetar, não nos parece aceitar como válido e é muito fácil demonstrar porque. Basta rápido exame no memorial da Comissão do Plano Diretor, para se verificar que a Câmara procurou atender a necessidade urgente de se suspender os loteamentos para que se faça o plano diretor. Assinaram esse parecer além de outros técnicos, o próprio Sr. Consultor Jurídico da Prefeitura, que nessa comissão representava a Ordem dos Advogados do Brasil. Aprovada a Lei, como se explica que o mesmo consultor que aconselhou a Câmara vá ao Executivo dizer que a lei é inconstitucional? Basta um confronto dos dois documentos para se verificar que não assiste ao Executivo o direito de vetar a lei, sustentado por um parecer tão contraditório (apud FARIA: 2007: 380)

Por fim, o episódio do veto leva ao desmantelamento da Comissão Especial do Plano Diretor da Cidade de Ribeirão Preto, com o pedido de demissão dos seus principais membros. 
Tendo transcorrido o prazo regulamentar do pedido de vistas feito pelo presidente da Comissão de Justiça, o veto total do prefeito municipal entra novamente em discussão plenária na sessão 210 em maio de 1955. Nesta ocasião, o vereador petebista Marques Ferreira, sobe à tribuna para criticar a posição do prefeito, associando o veto à pressão de loteadores.

Partidários do veto, como o vereador Arthur Almeida e Romero Barbosa, defendem o prefeito, alegando não existir nenhuma ameaça ou intimidação. Ainda durante a sessão da Câmara 210, o vereador Adalberto Teixeira clama pela discussão do veto do projeto de lei 19/55, que seria importante para regulamentar a proibição de novos loteamentos a fim de serem terminados os trabalhos do Plano Diretor da Cidade. Alegando o agravante de já ter sido convidado o urbanista Oliveira Reis para auxiliar o trabalho de elaboração, o mesmo vereador enquanto presidente da Câmara, encerra a sessão convocando outra plenária extraordinária para o dia 1 de junho. Entretanto, esta sessão, novamente, não derruba o veto total do prefeito.

No dia 8 de agosto de 1955, o urbanista José de Oliveira Reis prosseguiria com sua palestra já com a Comissão Especial do Plano Diretor da Cidade bastante desmantelada. Na tribuna ele diria o seguinte:

Cabe-me agora dar uma breve explicação a respeito de um esquema de plano diretor que tive a oportunidade de elaborar em 1945, para a área urbana de Ribeirão Preto, de acordo com os parcos elementos de que dispunha naquela época. Na ligeira exposição a guisa de observação e notas explicativas do esboço apresentado, esclarecia ao então Prefeito Dr. Alcides Sampaio que o "plano era apenas, esquemático, devendo sofrer as modificações julgadas necessárias à melhor adaptação às condições locais, sejam topográficas, técnicas, econômicas, financeiras ou sociais".

Partindo dessa premissa, estou bem a vontade para discutir o esboço, cuja apresentação teve o mérito de, a meu ver, ser um inicio de conversa. Como afirmei, também, não havia rigidez absoluta na sua programação, o que significa uma porta aberta para uma serie de melhores sugestöes que seriam analisadas e discutidas por quem de direito.

È evidente que a análise e a discussão já deveriam ter sido iniciados, pois dez anos já decorreram. Desconbeç, entretanto, qualquer iniciativa a esse respeito. De qualquer modo, é preciso que seja instituído um órgão departamental para a elaboração do planejamento regional, como frisei. (REIS: 1955: 7)

Na sessão 211 o vereador petebista Marques Ferreira subiria novamente à tribuna para acusar de corrupção passiva os funcionários do Departamento de Engenharia. Segundo o vereador, existiria uma "boca pequena" caracterizada pela distribuição de lotes aos funcionários do Departamento nos loteamentos aprovados pela Prefeitura durante aquelas duas décadas, entre 1940 e 1950, quando se assistira na cidade a uma explosão de crescimento imobiliário. Ele também solicita, no final do discurso, uma Comissão de Inquérito para investigar tais casos de corrupção e cita os funcionários nominalmente. Em votação secreta, o veto é mantido por 11 vereadores favoráveis e 6 contrários. Na sessão 212 o Sr. Gavino Virdes apresenta à presidência da Câmara o seu pedido de renúncia, que culmina naquele processo de desmantelamento da Comissão Especial do Plano Diretor.

Numa carta ao urbanista José de Oliveira Reis, os vereadores integrantes da Comissão Especial do Plano Diretor da Cidade diriam que:

A comissão especial do plano diretor está no momento sem ação, de vez que a maioria dos membros solicitaram demissão, inclusive eu, pelo fato do prefeito continuar a aprovação de loteamentos 
indiscriminadamente na cidade em terrenos rurais, vindo, por conseguinte prejudicar o trabalho de elaboração do Plano. (FJOR/APHRP apud FARIA, 2007, p.383)

A aprovação do projeto de Plano Diretor elaborado por José de Oliveira Reis para ordenar o uso e a ocupação do solo da cidade de Ribeirão Preto é fundamentalmente prejudicada pela atuação de funcionários corruptos na administração do município, cuja articulação do esquema de fraude acaba sendo respaldada pelo veto do prefeito udenista José da Costa. Porém, mantendo-se de maneira otimista durante a sua exposição aos vereadores da Câmara Municipal, Oliveira Reis termina a sua palestra em Ribeirão Preto assim:

Pela nova planta na escala de 1:10.000 da cidade que recentemente recebi do Sr. Prefeito José Costa verifico que houve uma expansão bem grande de novos loteamentos neste espaço de dez anos, além dos limites urbanos.

Urbanisticamente seria de desejar que tais loteamentos fossem mais restritos. È fácil explicar, pois os mesmos visaram antes de mais nada o sucesso financeiro em detrimento do lado urbanistico.

Contudo, não é para se desesperar porquanto muita coisa ainda pode ser salva e corrigida.

E esperando que isso aconteça para o futuro que peço licença para insistir mais uma vez, pois, nunca é tarde para começar.

Procuramos formar uma sadia mentalidade de urgente necessidade de um plano de urbanização para Ribeirão Preto, estendendo para todo o Município e se transformando no Plano Regional da Capital do Oeste abrangendo toda a zona de influencia nos municípios vizinhos. (REIS: 1955: 9)

A expansão futura da cidade se dará, dessa maneira, praticamente, sem nenhuma legislação urbanística que sistematizasse o uso e a ocupação do solo pelos inúmeros loteamentos que seriam lançados ao longo da segunda metade do século XX.

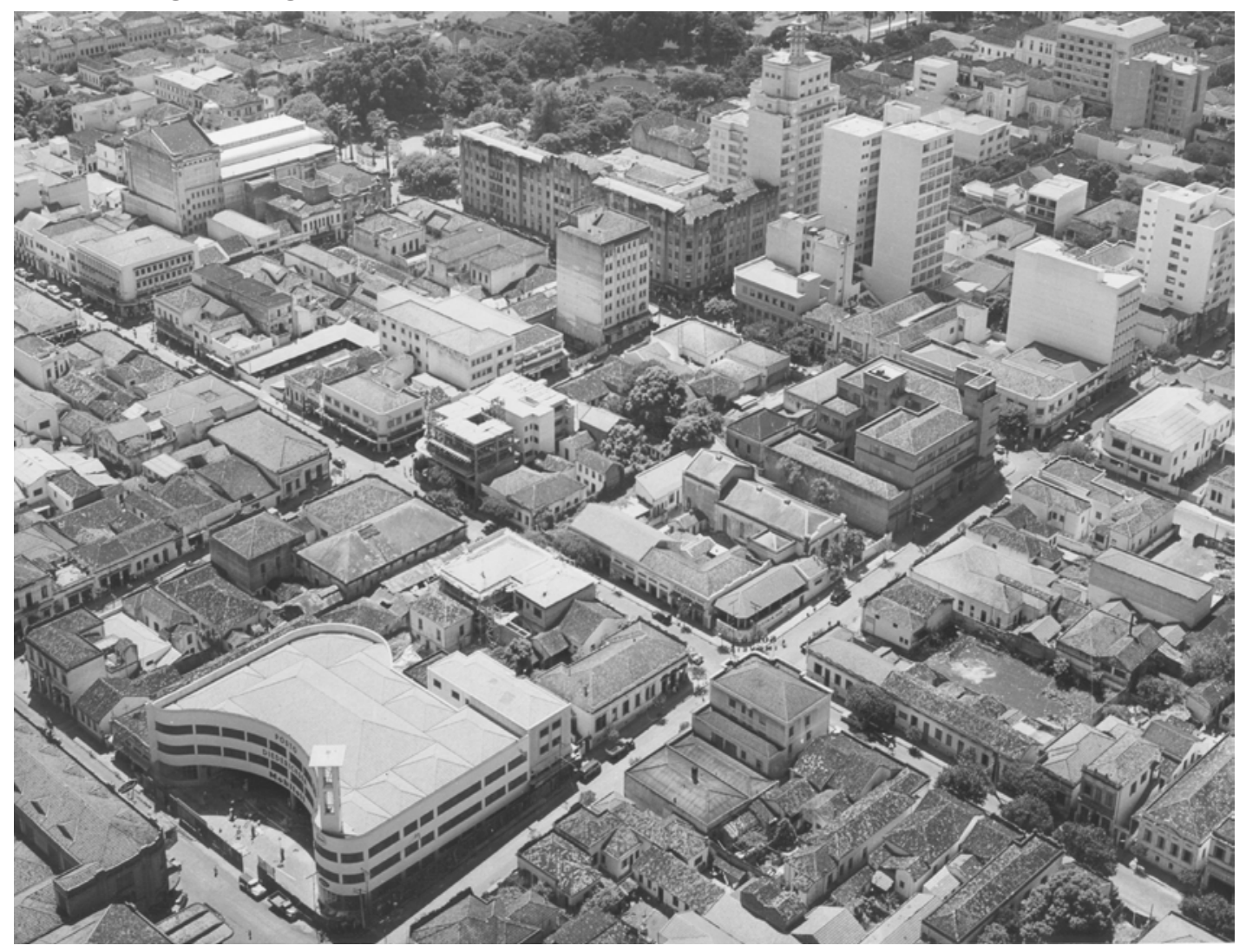

Figura 35: o adensamento e a verticalização da cidade. Fonte: APHRP. 


\subsection{Os loteamentos residenciais da zona sul de Ribeiráo Preto.}

Nas décadas de 1940 e 1950, justamente entre a primeira visita de José de Oliveira Reis e a sua segunda visita realizada pelo urbanista para proferir a palestra "o urbanismo e a sua influencia no município", a cidade de Ribeirão Preto sofreu um boom de crescimento tanto espacial quanto demográfico. Durante esse período, a Diretoria de Obras da Prefeitura Municipal esteve abarrotada de plantas de loteamentos que esperavam a aprovação dos técnicos da administração, situação que se tornou um grave empecilho à aprovação do Plano como um instrumento da legislação urbanística de Ribeirão Preto. Tanto no esquema elaborado em 1945, quanto na palestra realizada em 1955, o urbanista José de Oliveira Reis prescrevia a suspensão da aprovação dos loteamentos para assegurar a adequada implantação do Plano Diretor como guia da expansão futura da cidade.

O plano estabeleceria regras fundamentais de uso do solo, restringindo à ocupação urbana de determinadas áreas como as várzeas dos rios que se transformariam em parkways; ou as regiões mais altas que seriam reservadas para abrigar vegetação. Ambas as delimitações contribuiriam para amenizar o clima da cidade, além de criar novos espaços livres para o recreio da população. Outras faixas de terras no interior do perímetro urbano também estariam restritas à ocupação habitacional em virtude delas possuírem a função de intercalar as Unidades de Vizinhança. Ou seja, inspirado em concepções urbanísticas modernas, o urbanista José de Oliveira Reis propunha claramente uma cidade menos adensada. A aprovação do Plano Diretor teria um enorme impacto no mercado imobiliário de Ribeirão Preto, gerando a reformulação tanto dos desenhos das plantas dos bairros quanto da quantidade de lotes a ser colocada a venda pelos mais de 200 loteamentos que aguardavam a aprovação da Diretoria de Obras da Prefeitura Municipal.

Algo curioso nesse contexto envolve o desdobramento da configuração dos bairros na zona sul da cidade. Os desenhos dos seus loteamentos já começam a aparecer nos mapas do município desde o final dos anos de 1930, antes ainda de suas aprovações pela Diretoria de Obras e da construção das primeiras casas, que só irá ocorrer durante a década de 1940. Sem dúvida, entre aquelas 200 plantas que aguardavam aprovação durante as polêmicas em torno da suspensão dos loteamentos, estavam as do Jardim Eugênia, Jardim Sumaré, Jardim Europa, Jardim América e o Alto da Boa Vista. Sendo os bairros que irão ocupar a zona sul da cidade na metade do século XX.

A suspensão da aprovação desses loteamentos a favor do Plano Diretor contrariava grandes interesses no mercado imobiliário da cidade. Contudo, de forma quase irônica, embora o processo de criação desses bairros tivesse sido crucial para o veto do prefeito José da Costa ao PL-19/55, sendo crucial para a não aprovação do Plano elaborado por José de Oliveira Reis, os desenhos das plantas dos bairros recebem de maneira bastante achatada alguns elementos das concepções urbanísticas do ideário de cidades jardins, claramente uma referência ao urbanista José de Oliveira Reis na elaboração do Plano Diretor de Ribeirão Preto.

As ideias de Ebenezer Howard, autor de Cidade Jardins de Amanhã, rondavam a cabeça de 
urbanistas e loteadores envolvidos em processos de expansão urbana desde cidades europeias até à construção dos primeiros subúrbios-jardins no Brasil. No caso de Ribeirão Preto, assim como em diversas outras cidades, elas se tornaram, principalmente, uma referência na construção de bairros de classes altas associados a inversões maiores de capital imobiliário. Pouco mais tarde, estes bairros da zona sul de Ribeirão Preto serão regulamentados como exclusivamente residenciais nas décadas de 1940 e 1950, sendo o motivo da divisão política entre os vereadores da Câmara Municipal.

Essa legislação que se criara em Ribeirão Preto tinha uma correspondência com as leis parciais do zoneamento de São Paulo. Tomando o Acto 127, apresentado por Sarah Feldman (2005) como uma das primeiras leis que irão estabelecer os elementos básicos do zoneamento paulistano, se tem um novo modelo de controle do uso e ocupação do solo. O Acto estabelecia a demarcação de zonas funcionais, delimitando áreas onde só seriam permitidas, por exemplo, habitações particulares e residenciais, algo que se remetia ao esquema de Unidades de Vizinahnça. Assim, através de uma transposição do zoning norteamericano se evidencia duas consequências relacionadas a implentação desse tipo zonemeamento que começa a ser implementado em São Paulo e Ribeirão Preto a partir da década de 1940: a proteção das áreas de maior prestígio e a proteção do valor de seus terrenos.

No caso paulistano, Sarah Feldman (2005) apresenta a região da cidade que será alvo dessa valorização da seguinte forma:

A rona em questão é criada na área delimitada pelas ruas Estados Unidos, Brigadeiro Luiz. Antonio e Dona Hyppolita, no Jardim América, primeiro bairro planejado pela Cia. City, em São Paulo. Projetado pelo arquiteto inglês Barry Parkerpara a elite paulistana, seguind o modelo da cidade jardim de Ebenezer Howard, o bairro começa a ser implantado em 1915, em uma área de mais de um milhão de metros quadrados, próximo à várzęa do rio Pinheiros. Esta localização, tida como inóspita devido à sua extrema umidade, exigin elevados investimentos da empresa para criar todos os atrativos para os futuros clientes. O bairro é subdividido em lotes em torno de mil $\mathrm{m}^{2}$ e, de início projetado para conter edifícios públicos, equipamentos culturais e esportivos, além de um distrito comercial, após várias reformulaçöes torna-se estritamente residencial. Concebido como um conjunto em que o traçado das rua, a volumetria, a prporção de áreas verrdes, compõem um bairro que a Companbia pretende marcar como padrão de seus empreendimentos, sendo estabelecidas, em contrato, restrições que impedem ao proprietário alteraçôes dos padrões de uso e ocupação dos lotes adquiridos. (FELDMAN: 2005: 154-155)

Das inúmeras concepções urbanísticas surgidas ao final do século XIX, as propostas de Ebenezer Howard encontraram grande repercussão. Foram inúmeros os países que as receberam adaptando-as às diversas condições sociais, econômicas e políticas. A força de seu conteúdo utópico - reaproximação entre campo e cidade - aliada à pragmática de sua implantação influenciou a configuração de paisagens em diversas cidades do mundo. Tais ideias surgiriam em meio às mudanças no tecido urbano provocadas pela revolução industrial e pelo crescimento demográfico, sendo uma resposta à quebra do antigo equilíbrio das cidades medievais.

Howard diria:

É quase universalmente aceito por homens de todos os partidos, não somente na Inglaterra, mas em toda Europa, América e em nossas colônias, ser profundamente deplorável que pessoas continuem afluindo as cidades já superpovoadas, esvaziando ainda mais os distritos rurais (HOWARD: 2002: 105).

Numa linha reformista, teóricos como Howard, bem como os industriais Robert Owen e 

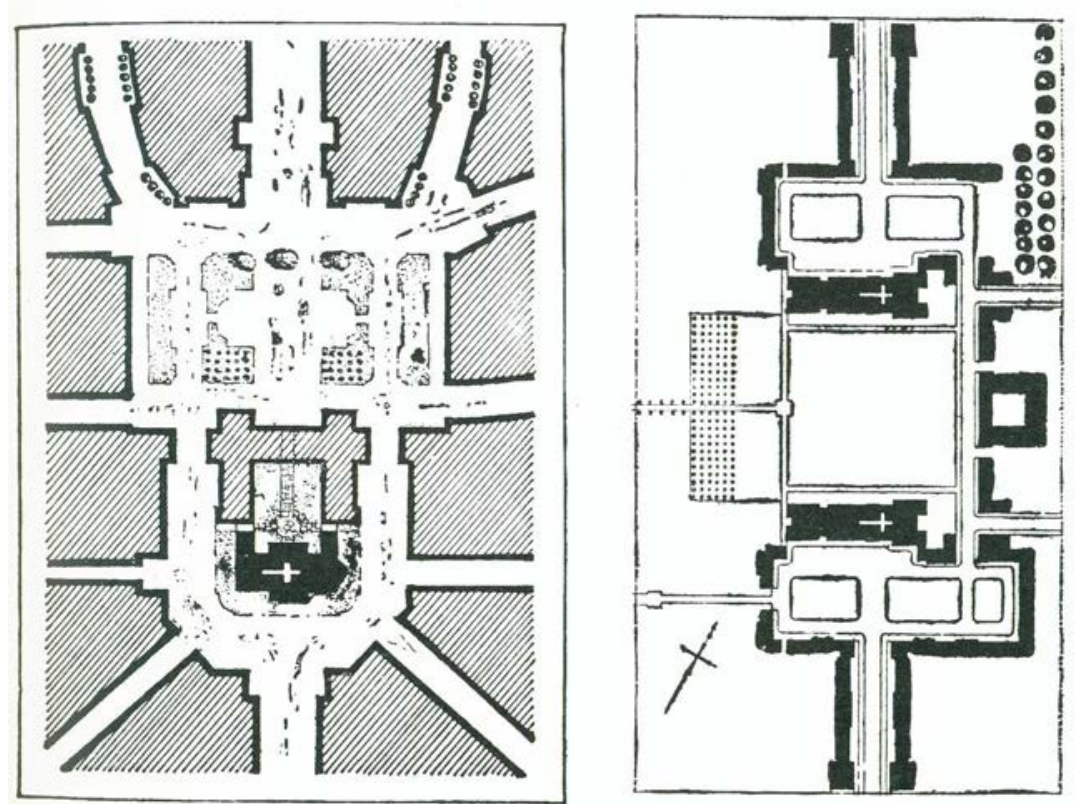

Figura 34: As Praças Centrais de Letchworth e Hampstead Garden Suburb numa releitura das discussões de Camillo Sitti nos empreendimentos de integrantes da Garden City Association. As praças dos bairros da zona sul de Ribeirão Preto também ganharam um cuidado e um tratamento especial diferenciando esses bairros dos restantes da cidade. Fonte: Unwin: 1984: 167.

Charles Fourier,. elaboraram projetos utópicos de cidades novas inspirados em autores como John Ruskin e William Morris. Esse homens eram críticos a sociedade industrial, propondo modelos teóricos que resgatassem os valores culturais perdidos no século XIX. As novas cidades seriam menos adensadas e possuiriam dimensões modestas, os seus projetos seriam realizados sem a imposição de traços geométricos com respeito à organicidade e aos valores estéticos de cada localidade. ${ }^{51}$ Camillo Sitte, expoente dessa vertente urbanística, influenciaria diversos arquitetos com as suas concepções de espaço modular e respeito à especificidade de cada conjunto urbano., algo que preservaria o valor das praças como espaços públicos fundamentais, além de estabelecer o diálogo entre reforma e restauro da cidade enquanto um espaço harmônico sem oposições e conflitos.

Analisando os livros e fichas do $1^{\circ}$ Registro de Imóveis da comarca de Ribeirão Preto se encontra "O registro do LOTEAMENTO denominado 'Jardim Sumaré, feito em 5 de agosto de 1948. Situado nos subúrbios da cidade, ele possuiria uma área de $268.752 \mathrm{~m}^{2}$, sendo de propriedade de José Newton Ferreira da Rosa e sua mulher, Eddy Tavares Ferreira da Rosa ${ }^{52}$. O loteamento Jardim Sumaré fora composto por duas glebas de terras anexadas para realizar o arruamento e a disposição dos lotes, sendo a maior parte $(247$ mil m²) destacada da Fazenda "Santo Antônio do Sumaré”, que José Newton Ferreira comprara de José Fernandes, que já havia vendido um terreno à Empresa de Força e Luz para instalação de uma Subestação da rede de distribuição de energia.

Mesmo assim, José Fernandes ainda permanece como proprietário de uma reserva de terras maior, ao sul do Jardim Sumaré, como é possível ver na planta do bairro. Mais tarde, estando mais valorizada, esta gleba de terra será vendida a Godofredo Leite Fiúza, transparecendo uma prática

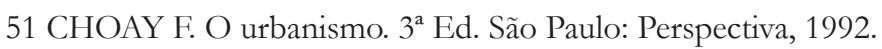

52 Trecho da certidão realizada no $1^{\circ}$ Registro Imóveis, protocolo no ${ }^{\circ} 524.058$. 


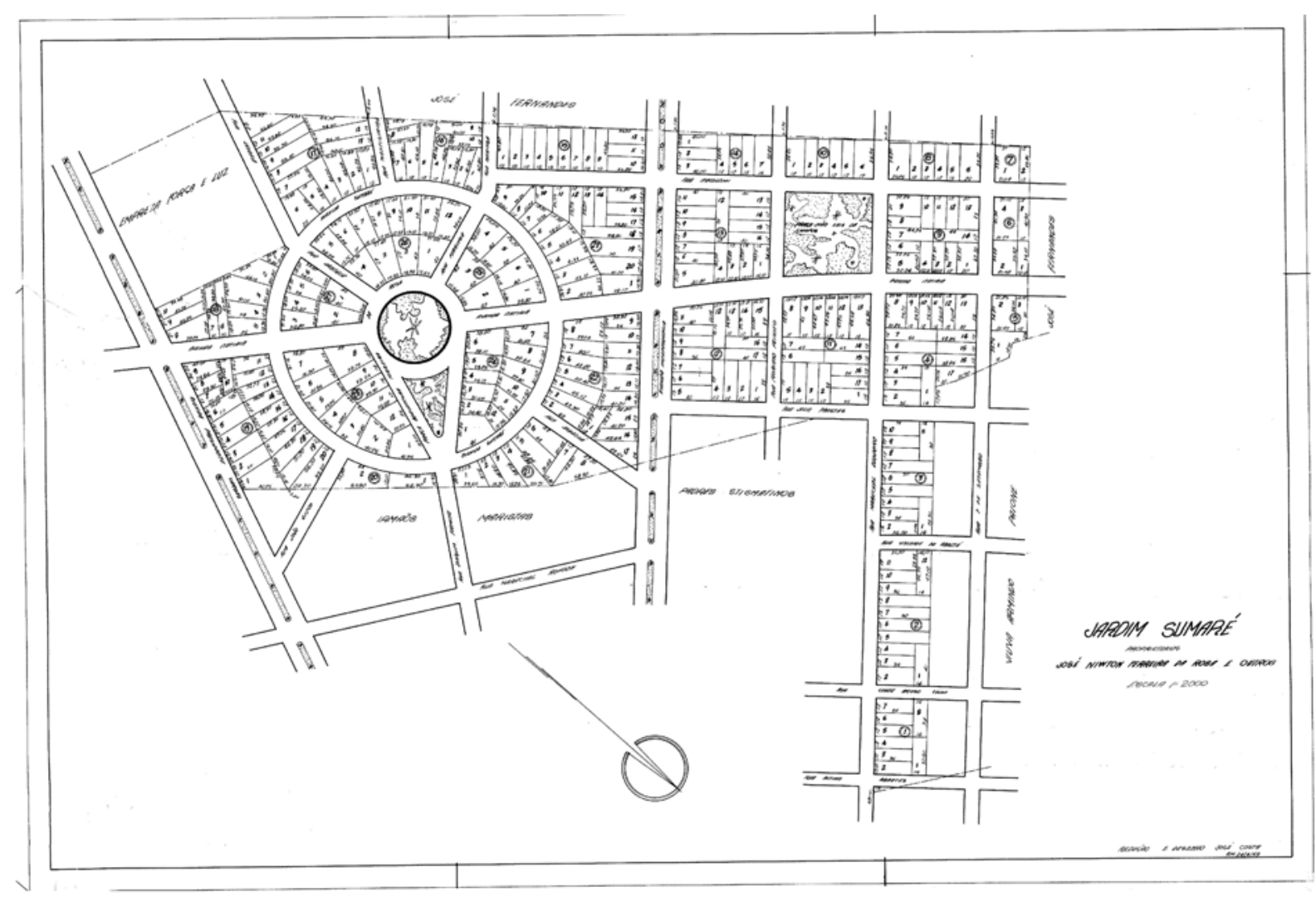

Mapa 17: no desenho da planta do loteamento se vê algo inédito na morfologia urbana da cidade, pela primeira vez, os lotes maiores que no restante da cidade serão dispostos em vias circulares, tendo como eixo do bairro duas Praças - uma primeira Praça Circular, que é complementada por uma segunda no formato de um triangulo. A abertura proporcionada pela segunda praça triangular permitiria a constituição de um mirante em direção a parte mais baixa da cidade. Fonte: PMRP.

bastante usual entre os especuladores de terrenos que vão sucessivamente se transformando em cidade. Nessa região, Godofredo L. Fiúza irá implantar o bairro Alto da Boa Vista com um plano de arruamento semelhante ao Jardim Sumaré compondo uma região homogênea nesta parte da cidade (ver os mapas 20 e 21).

O memorialista Rubem Cione (1997) chamará estes loteamentos que compõem a zona sul de Ribeirão Preto de complexo Sumaré - Boa Vista, numa região que englobava as mais belas avenidas da cidade, como a Presidente Vargas, Independência, Itatiaia, Sumaré e João Fiúza, além da futura construção de um Shopping Center.

\section{JARDIM SUMARÉ}

Projetado desde o inicio para ser um bairro nobre, o Jardim Sumaré foi fundadoem 1948 por Nilton Ferreira da Rosa, que teve a colaboração de João Nutti, proprietário da imobiliária que leva o seu nome, para promover o loteamento nas terra de uma antiga fazenda cujo proprietário era José Fernandes, conhecido como Zé Espanhol e que, segundo consta na história da cidade, perdeu o dinheiro após vender a área. A feição do local e a construção de mansões levou à criação de outros loteamentos, como o Jardim da Aclimação, Jardim Eugênia, Jardim Nove de Julho e o Alto da Boa Vista, o de maior destaque, loteado pelo fazendeiro Godofredo Fiúza e pelo advogado Rocha Lourenço (CIONE: 1997: 598)

No Jardim Sumaré, outra área menor $\left(20 \mathrm{mil} \mathrm{m} \mathrm{m}^{2}\right.$ havia sido adquirida da chácara "São João", pertencente à Dona Alzira de Mura Paione, provavelmente uma senhora que desconhecia as possibilidades de lucros no novo mercado imobiliário de Ribeirão Preto. Tais terras comporiam o espaço do loteamento sendo vizinhas e, posteriormente, divididas pela Rua Marechal Deodoro, 


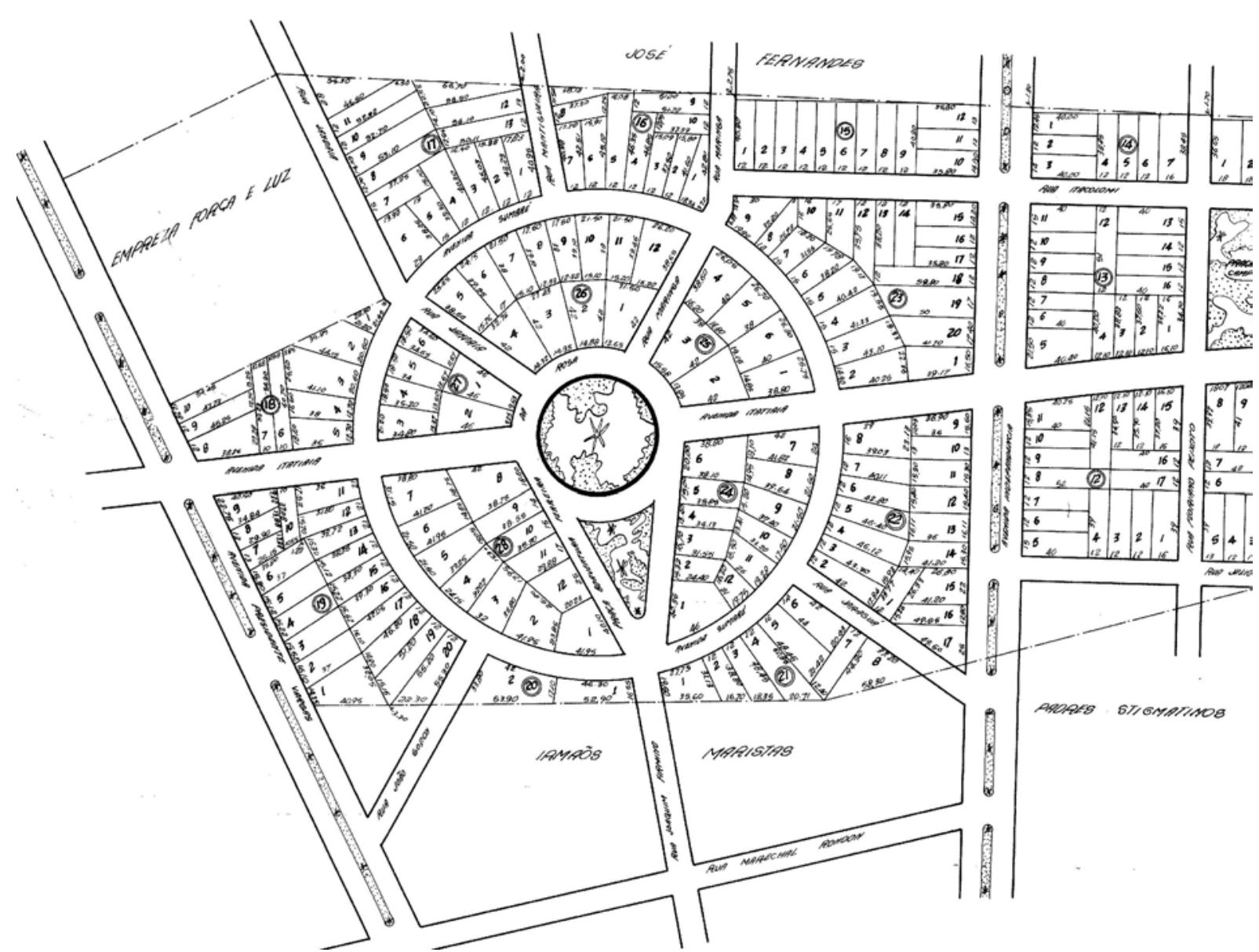

Mapa 18: As duas Praças e a Avenida Sumaré (via circular proporcional ao circulo da Praça) se impondo como o centro do bairro. Fonte: PMRP.

aos terrenos do seminário "Gaspar Bertoni”, local que a Associação dos Padres Estigmatinos destinaria à construção de uma Igreja e um Seminário para fins de educação e instrução popular. O loteamento ainda fazia fronteira com a chácara dos Irmãos Maristas, que possuíam uma escola de instrução básica instalada no alto da cidade.

Ao olhar a planta do loteamento Jardim Sumaré, é possível perceber que o seu desenho foi resolvido pelo eixo formado pelas duas avenidas - Avenida Itatiaia e Avenida Independência - que dividem o bairro em quatro partes. Porém, se realça no bairro o conjunto de sua Praça Central, composta por uma circunferência e um triângulo redefinindo a malha viária com vias diagonais e ruas curvas, dando um resultado pitoresco no alinhamento das casas bastante típico de traçados orgânicos defendidos por Camillo Sitte em Der Städtebau.

No memorial descritivo do Jardim Sumaré, aparecem restrições quanto ao uso e ocupação do solo do bairro destinado preferencialmente a edifícios residenciais de baixa altura. Apesar de um zoneamento destinar alguns lotes para estabelecimentos comerciais, o bairro foi constituído nas décadas de 1940 e 1950 como de residências de alto padrão, abrigando mais recentemente, a partir dos anos 2000, o comércio de lojas de grifes e restaurantes.

Os terrenos se destinam de um modo geral a construção de prédios residenciais exceção feita dos seguintes lotes que poderão ser ocupados por estabelecimentos comerciais: quadra n¹1, lotes 10 e 11; quadra $n^{\circ} 16$ idem 9 e 10, idem 18, idem 6,7 e 8 (CERTID Â: $n^{\circ}$ 524.058) 
Também foram estabelecidas para o bairro algumas regras de edificações para assegurar o padrão homogêneo de moradias unifamiliares. Assim, as casas tinham de ser implantadas ao centro do lote, sendo vedada a construção de edifícios que pudessem abrigar mais de uma família. $\mathrm{O}$ adensamento de moradores extrafamiliares em uma habitação era comum nas pensões que se constituíam no centro de Ribeirão Preto a despeito de ações policiais de despejos asseguradas pelos Códigos de Posturas republicanos. No Jardim Sumaré se estabeleceria outro padrão de moradia, até então inédito na cidade: residências unifamiliares, em sua maioria térreas, implantadas ao centro do lote e separadas por muros baixos, ou cercas vivas para garantir a visibilidade da região.

As edificações nos lotes destinados as residências deverão obedecer as seguintes regras: a) em cada lote de terreno não será construído mais de um edifício e receptivas dependências, o qual será destinado exclusivamente a habitação particular, sendo vedada a construção ou instalação de casas geminadas, de habitacões coletivas e de quaisque restabelecimentos industriais, comerciais ou profissionais (CERTID ÂO: $1^{\circ}$ Registro de Imovéis)

Essa garantia de padrão visual será assegurada pelo memorial do loteamento na medida em que ele estabelece o limite de dois pavimentos para as casas, além de regulamentar os recuos das residências em cinco metros da via pública e de três metros para as faces laterais das casas.

b) tal edifício não terá mais de 2 pavimentos sendo porem permitida a construção de sótão, ático ou porão habitável, a juízo das autoridades públicas competentes c) em relação ao alinhamento da via pública a edificacão principal obedecerá ao recuo mínimo de cinco metros considerando-se como parte integrante do edificio e também sujeitos mencionado recuo os terraços, alpendres e outras salienciais do prédio, ficando esse recuo reduzido para três metros em relação a face lateral dos lotes de esquina. (CERTID ÃO: $1^{\circ}$ Registro de Imovéis)

Os traçados desses bairros transcendiam a Avenida 9 de Julho no sentido da Villa Bonfim, quebrando a repetição do tabuleiro de xadrez das quadras do perímetro central. Na medida em que os traçados avançam topograficamente, eles rompem o tabuleiro no interior dos bairros por meio de rotatórias, vias circulares e praças, constituindo espaços de recreação e contemplação de paisagens. Muitas dessas diretrizes de desenho de vias, padrão de edificações e limites de adensamento habitacional são encontrados em processos de expansão urbana semelhantes no percurso do decaimento das concepções de cidades-jardins para as de subúrbios-jardins. Esses novos bairros se constituíam como enclaves urbanos em cidades que cresceram e se adensaram ao longo dos séculos XIX e XX.

Nesse processo, são fundamentais as formulações de Raymond Unwin, em Town Planning in Practice, de 1909. Nesta obra Unwin, adéqua os princípios de Ebenezer Howard e Camillo Sitte a concepções de desenhos de fragmentos urbanos sobre cidades já existentes. Para isso, Unwin elenca as praças como espaços públicos privilegiados, além de destacar a beleza das ruas curvas em traçados orgânicos. Os empreendimentos de subúrbios e bairros com a inspiração destes dois elementos passam a se realçar na morfologia urbana, e o deslocamento do ideário de cidades-jardins para as novas áreas de expansão ganha um manual de planejamento. A obra de Unwin chega a ser criticada por Ebenezer Howard, que o acusa de estar descaracterizando a sua proposta original ao promover a fragmentação urbana das cidades num processo de segmentação social.

O projeto de Hamptead Garden Suburb, de Raymond Unwin e Barry Parker, abandona a 


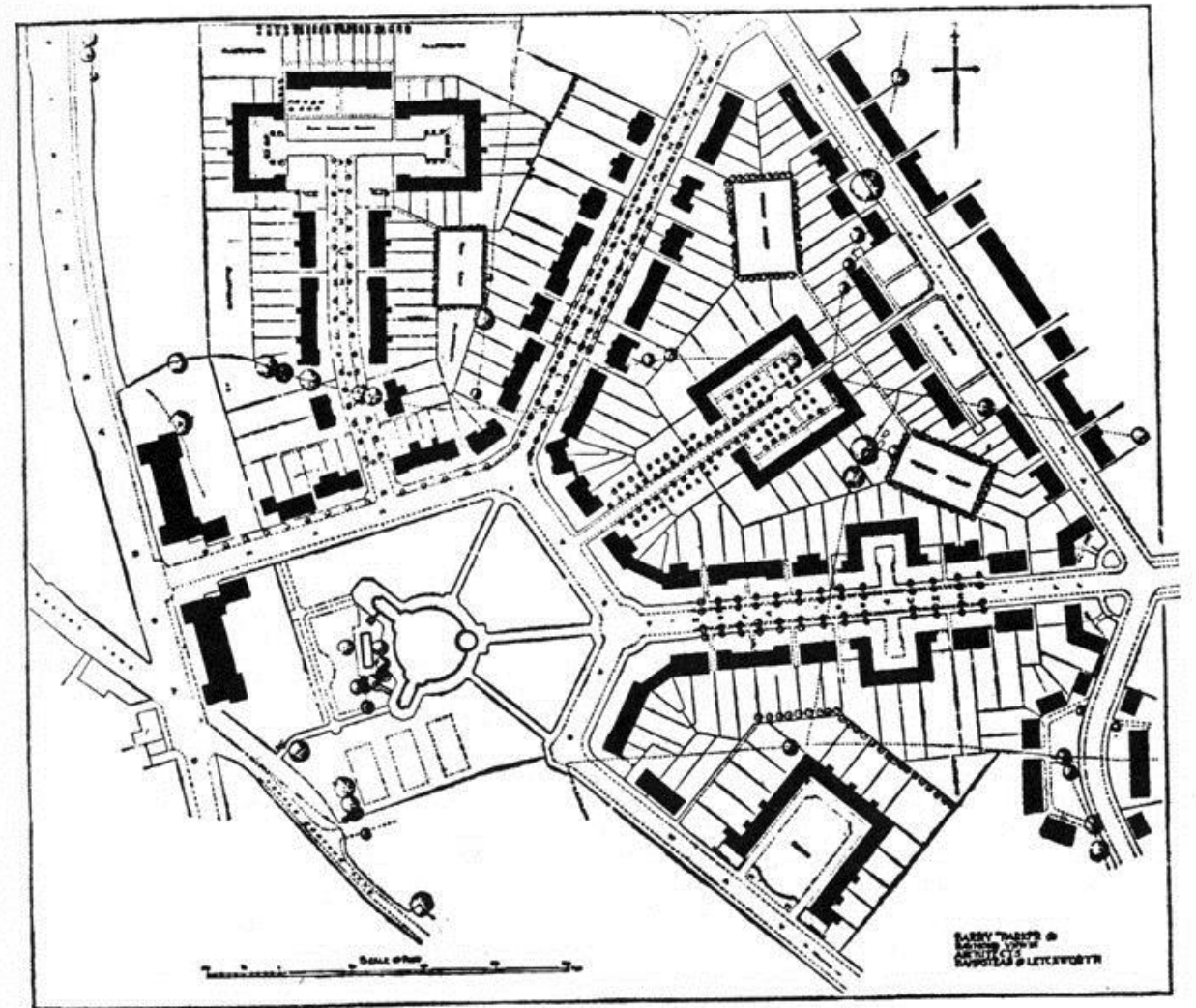

Figura 35: Fragmento do Hampstead Garrden Suburb desenvolvido pela Hamstead Limited e destinado a moradias unifamiliares no surburbio de Londres. Fonte: UNWIN: 1984: 233.

integralidade das concepções de Howard na criação de apenas um bairro em Londres. Hamptead logo se torna o destino de classes abastadas que procuravam se refugiar nos arredores londrinos após o seu enorme crescimento urbano. A área residencial, com equipamentos como igreja, escola, galerias e museus, promoveria uma nova homogeneidade social, sendo até hoje uma das regiões de mais alto custo de vida na capital inglesa com mansões sendo vendidas a valores elevadíssimos.

Segundo Unwin, a ideia de subúrbio-jardim partia da dificuldade enfrentada pelos planos urbanísticos de evitar o adensamento urbano. Por isso, ele propunha um sistema de compensação aos proprietários de glebas de terras como uma forma de desestimular o adensamento dos loteamentos. Assim, a baixa rentabilidade da venda de lotes seria compensada pela municipalidade através de um pagamento sobre as benfeitorias urbanas dos loteamentos. Uma solução compensatória típica de propostas reformistas, Unwin também defendia a cláusula inglesa do Town Planning Act, que limitava o número de casas por hectare ao invés de indenizar os proprietários desapropriados em razão de obras urbanas. Desse modo, embora Unwin critique o adensamento urbano e a ocupação de antigas fazendas sem planejamento de conjunto, os subúrbios-jardins, em virtude da valorização imobiliária, se tornam uma opção de moradia apenas às classes sociais mais abastadas.

O ideário urbanístico das cidades-jardins, como pode ser visto, se difundiu na medida das viagens dos diversos arquitetos, urbanistas e paisagistas que estiveram envolvidos com a Garden City Association. Casos como da visita de Frederic Olmsted à China e à Europa, do próprio Ebenezer Howard aos EUA, na viagem de Patrick Geddes e Raymond Unwin à Alemanha, de Joseph Bouvard 


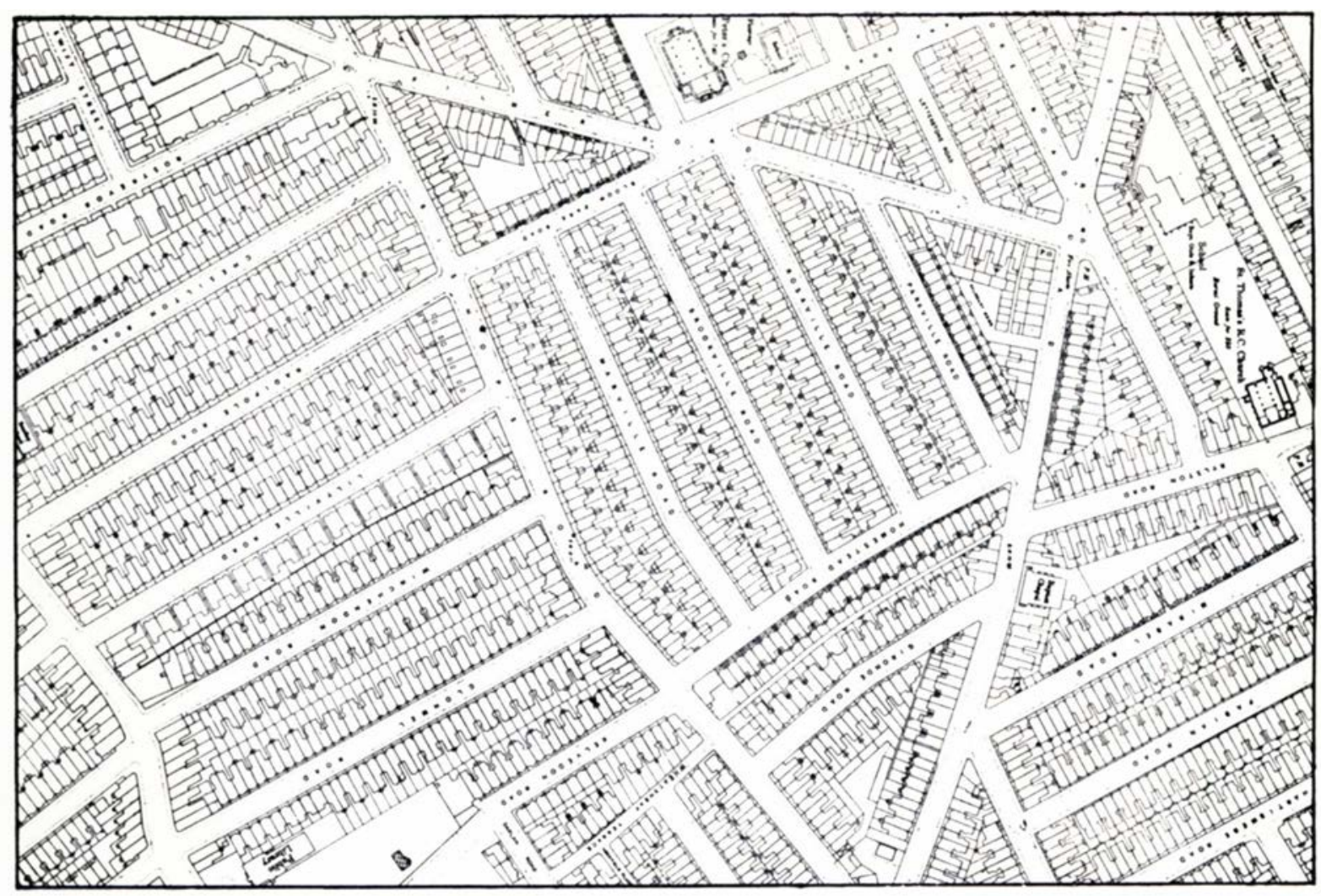

Mapa 19: As Ordenanças de Edificações inglesa teria gerado resultados muito monótonos e feios, sem atrativos do ponto de vista pitoresco como a beleza de bairros mais antigos. A imagem é um exemplo do desenvolvimento urbano em Fulhan (Londres). A grande densidade desses bairros operários irá contrastar com os enclaves urbanos gerados pelos subúrbios jardins como Hampstead. Fonte: UNWIN: 1984: 14.

à Buenos Aires e a São Paulo e, por fim, chegando ao Brasil, na estadia de Barry Parker em São Paulo. Nesse processo de difusão, tomando uma citação de Frederic Jameson (2006), se tem que: "quando a teoria estrangeira atravessa o Atlântico, tende a perder muito de suas implicações políticas e de classe". Ou seja, o intercâmbio de ideias sobre arquitetura e urbanismo, principalmente no que toca à ressonância do ideário de cidade-jardim, não se realizou sem mutações ou adequações a cada realidade histórica. Nas diversas reformas com essa inspiração, se perdeu a integridade do conteúdo reformista definido por Howard, não se reproduzindo em nenhuma cidade tal e qual a sua utopia.

Os aspectos comunitários da cidade-jardim, algo que se referia à propriedade fundiária e à gestão do assentamento, foram os elementos que mais sofreram alterações econômicas e sociais no movimento de sua difusão. Distorcendo a ideia de fraternidade e sustentabilidade, os empreendimentos com essa inspiração foram respaldados por um aparato legislativo utilizado para se assegurar uma proeminência apenas residencial.

Esse é o caso da zona sul de Ribeirão Preto, composta por bairros majoritariamente residenciais. Em 1954, isto será assegurado pelo projeto de lei no $10 / 54$ de autoria do vereador Marques Ferreira, que a delimitava como Zona Residencial. O projeto regulamentava essa região da cidade, normalizando o gabarito das casas, o alinhamento à via pública, as divisas de lotes, recuos laterais etc. A zona residencial de Ribeirão Preto incluía justamente os seguintes bairros: Jardim Sumaré, Jardim América, Jardim Recreio e o Bairro Alto da Boa Vista. 
Trata o Projeto de lei 10-54 de assunto de transcendental importância para a cidade, dada a forma desordenada com que têm sido construidas residências, mormente na chamada parte alta, em visivel atentado a estética urbana. A falta de um Plano Diretor tem causado danos irreparáveis à cidade, acrescido ainda de estarmos obedecendo a um Código de Obras obsoleto. No nosso entender, salvo melhor juizo, o projeto de lei 10-54 preenche à suas finalidades e vem sanar grave lacuna no crescimento impressionante de nossa cidade, devendo ser ouvida, entretanto, a Diretoria de Obras para pronunciamento técnico, enviando-se - outrossim - cópia - do presente PL a Associação dos Engenheiros de Ribeirão Preto, solicitando a mesma, igualmente, parecer técnico (Documento anexado ao PL n 10-54, Biblioteca da CM de RP apud FARIA: 2007: 221)

Segundo Calil Júnior (2003), o prolongamento da antiga "Avenida Independência", na década de 1950, acompanha a implantação desses bairros na região alta da cidade. O prolongamento da Avenida atenderia aos sistemas viários dos bairros que vão surgindo progressivamente aos loteamentos das fazendas e chácaras dessa região. Analisando uma planta realizada pela Prefeitura Municipal, em 1935, com a demarcação dos proprietários das glebas do perímetro urbano na região que transcende a Avenida 9 de Julho, se vê após as três quadras da Vila Veludo e da Vila Independência uma grande área demarcada como pertencente a Manoel Emboaba da Costa. Essa grande gleba de terra era dividida pela estrada para a Vila Bonfim, que será alvo de um projeto da Prefeitura Municipal para torná-la uma rodovia.

A antiga estrada entre Ribeirão Preto e a Villa de Bonfim acaba perfazendo a fronteira entre estes dois bairros - o Alto da Boa Vista e o Jardim Sumaré. O caminho era objeto de um projeto de duplicação desde 1921, o que indicava a valorização deste vetor de crescimento urbano antes da realização da compra das glebas da Fazenda Santo Antonio do Sumaré pelos referidos loteadores:

\section{Estrada da Villa Bonfim RELATÓRIO}

Com este tenho a honra de passar às mãos de V. Excia. o projeto e o orçamento de uma estrada dupla desta Cidade à povoação de Villa Bonfim. Trata-se de uma estrada já construída e que apenas deverá ser em alguns pontos alargada e preparada afim de comportar os dois leitos: o de automóveis e o de outros veículos (...) o traçado da estrada existente não carece de ser mudado porquanto elle já tem o melhor comprimento vertical possivvel dentro de condições de declividade magníficas. Se elle deverá ser mudado, somente seria para o lado onde corre a linha Mogyana, o que não seria possível, visto como em grande extensão as duas estradas, a de rodagem e a de ferro, correm paralelas e quase unidas.

Beatriz Piccolotto Bueno (2010), em A cidade como negócio, demonstra a produção do espaço urbano pelo mercado imobiliário da cidade de São Paulo ainda no final do século XIX. Com o forte papel da iniciativa privada na definição da tessitura urbana, a autora enfatiza que a apropriação e a produção material da cidade sempre foram excelentes negócios desde o período colonial. Apesar de nos três séculos coloniais o mercado imobiliário de São Paulo ter se restringido ao antigo centro formado pela colina entre os rios Anhangabaú e Tamanduateí, após 1880 surge uma grande demanda para expansão dos loteamentos nas áreas do Rossio ${ }^{53}$ ou Termo ${ }^{54}$ da Vila de São Paulo.

No período que antecedeu a Lei de Terras, os terrenos urbanos eram concedidos pela

53 Rossio: áreas rurais no perímetro urbano concedidas pela Câmara Municipal, ainda um elemento da legislação portuguesa (os conselhos), depois ocorre à liberação dessas terras do rossio ao mercado livre imobiliário, porém antes disso foi uma área envoltória as Vilas de 1 légua e, segundo a legislação portuguesa, eram terras de uso comum.

54 Termo: nome de algumas áreas mais distantes do perímetro urbano, estão para além do rossio, e são postas no mercado livre pela lei de terras de 1850 


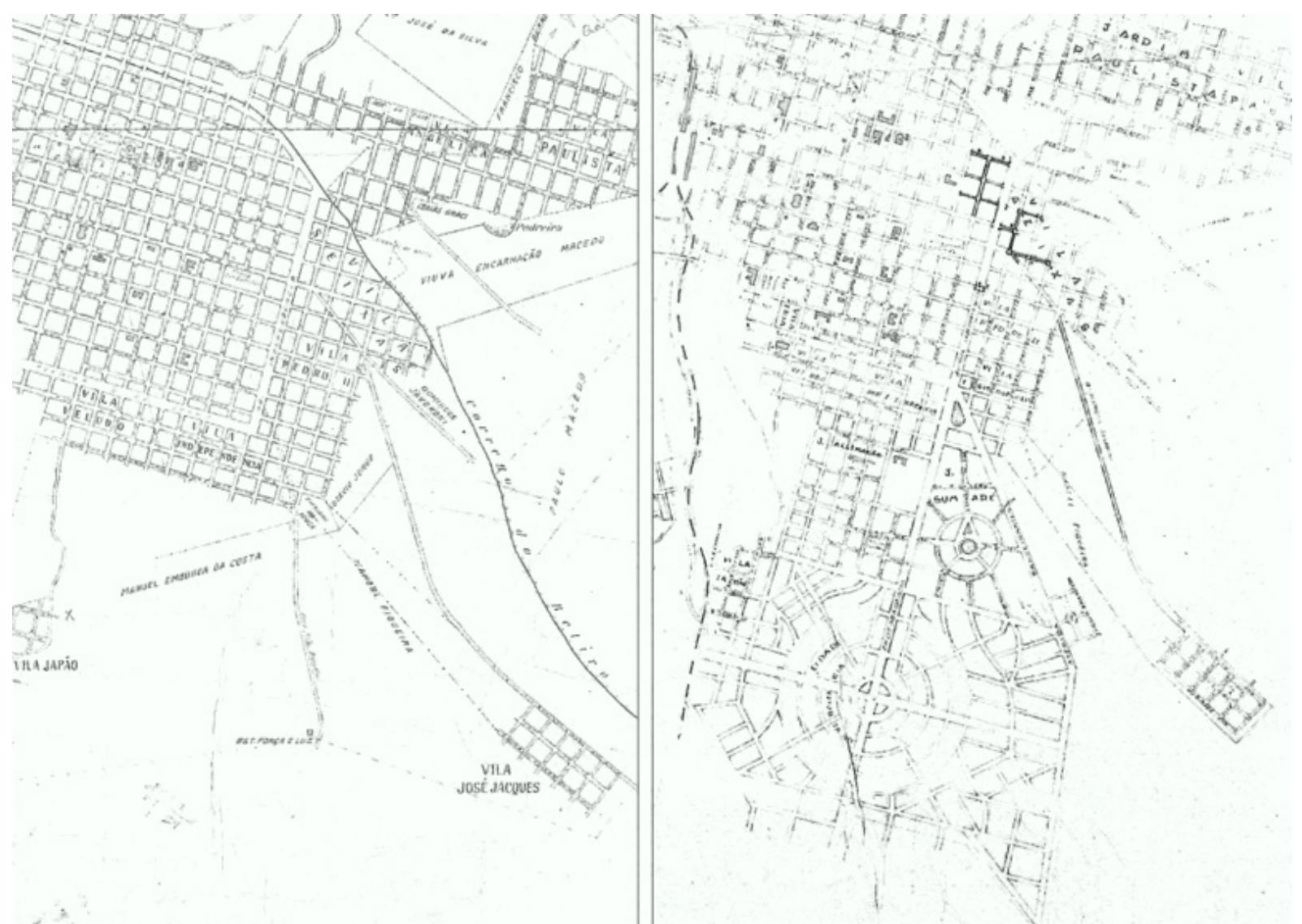

Mapas 20 e 21: Nos mapas é possível ver a transformação das glebas de terras da fronteira sul do Patrimônio Religioso em loteamentos com traçado orgânico. Conectados, o Jardim Sumaré e o Alto da Boa Vista irão constituir uma ampla região residencial distinta do resto da cidade formando um enclave urbano bastante comum em projetos de subúrbio jardim. Fonte: AESP.

Câmara Municipal, que cedia o domínio útil do lote gratuitamente ou mediante o foro ${ }^{55}$. A Lei de Terras, entretanto, elimina esse sistema de concessão e instaura a propriedade da terra urbana sem os entraves de alienação feudais. Durante a Primeira República, se extingue por completo a propriedade comunal ou o domínio útil particular dos terrenos da cidade de São Paulo, dando origem a um mercado de terras públicas pela sua Intendência Municipal.

A presença da Cia. City nesse mercado que se inaugura em São Paulo realça a reflexão, que não será possível de ser esmiuçada por esta dissertação, sobre as relações entre o capital financeiro e a especulação imobiliária na produção de espaços urbanos. O capital gerado pela especulação imobiliária desarticulado do processo produtivo de exploração de mais-valia daria origem à "renda da terra" como um fenômeno urbano vinculado à especulação imobiliária. Segundo os elementos dessa reflexão, as tipologias urbanas dos loteamentos exclusivamente residenciais adquirem muitas vezes a potencialidade de valorizar ainda mais tais empreendimentos em virtude de seus aspectos culturais e simbólicos.

No âmbito espacial, parece existir algo como um equivalente do capital financeiro, na verdade um fenômeno intimamente ligado a ele, que é a especulação imobiliária: algo que pode ter encontrado o seu campo de atuação no passado na área rural [...] na aquisição de imensas extensões pelas ferrovias, no desenvolvimento das áreas de subúrbio, junto com a privatização dos recursos naturais, mas que, no nosso tempo, é predominantemente um fenômeno urbano. (JAMENSON, 2006, p.258)

55 Quantia recolhida ao tesouro da Câmara Municipal 
Segundo Andrade (1998), a chegada da Cia. imobiliária inglesa City of San Paulo Immprovements and Freebold Land Company Limited, com a atuação do arquiteto Barry Parker, entre 1917 e 1919, é responsável pela transformação da paisagem urbana paulistana. A City vinha ao Brasil num contexto em que outras empresas de capital estrangeiro também estavam realizando a exploração da produção material da cidade - como a Light. Durante a Primeira República essas duas companhias irão articular os seus interesses com os antigos proprietários de grandes glebas através da penetração na Diretoria de Obras da Prefeitura de São Paulo.

A criação da Cia. City é articulada num juntar realizado em maio de 1911 pelo arquiteto Victor Dubugras, que havia convidado o urbanista Joseph Bouvard para trabalhar na urbanização de São Paulo após visitar Letchworth e Hampstead na companhia de Mr. Gurd, managing director da City no Brasil. Bouvard viera ao Brasil também como consultor de um financista belga interessado em negócios imobiliários após a liquidação do Banco Fontaine \& Co em Paris. O interesse de Fontaine de Laveleye ao contratar Bouvard ocorria em razão do contato deste urbanista com a prefeitura de São Paulo, para a qual realizaria uma planta de melhoramentos. A partir das projeções sobre as áreas que se valorizariam em São Paulo, Bouvard elabora um mapa com os terrenos a serem adquiridos pela Cia. City e o consórcio passa adquirir todas as glebas indicadas que irão compor o seu patrimônio.

Andrade (1998) demonstra que, das 15 residências de arquitetura expressiva, 11 delas se encontravam em bairros-jardins realizados pela Cia. City, o que contrariava os preceitos arquiteturais do próprio Barry Parker, que se inspirava no movimento Arts and Crafts sendo leitor de Walden ou a vida nos bosques de Henry D. Thoreau. As "cláusulas das servidões para o uso dos terrenos" escritas por Barry Parker delimitava o tipo de residência que seria construída no Jardim América: casas de duas frentes, uma para rua e outra para os jardins; metragens previstas de no mínimo de 130 $\mathrm{m}$; recuos de $4 \mathrm{~m}$ laterais para casas térreas e $6 \mathrm{~m}$ para sobrados; previsão de apartamentos para empregados, exigindo portas de entrada com pórtico ou patamar; fachadas de 25 metros com áreas mínimas $900 \mathrm{~m}^{2}$ de terrenos. Ou seja, o bairro se definiria de uso exclusivo de residências isoladas no lote com alturas baixas dos muros, produzindo a mesma permeabilidade visual das paisagens de Hampstead ou Riverside.

Em outros loteamentos da cidade de São Paulo, como os desenhados por Jorge de Macedo Viera, não se consuma as condições peculiares de valorização como no Jardim América. Os projetos não realizados pela Cia. City, mas por outros loteadores e engenheiros, se constituíram como bairros populares, ao leste do município, na vertente do rio Aricanduva, como a Vila Nova Manchester, a Vila Mathilde e a Vila Euthália, destinados aos operários que se localizavam junto à antiga estrada de ferro numa região que tem a ocupação acelerada, na década de 1930, após a instalação da Indústria Nitroquímica em São Miguel Paulista.

"A Nova Manchester', a grande cidade do trabalho, com terrenos apropriadíssimos para indústrias, se situa no próspero bairro Belenz̨inho, o maior centro operário desta capital, vos garantirá todos os meios precisos para o êxito de vossas indústrias porque ai tereis terrenos magníficos para as vossas instalaçôes e vilas operárias, por preços 20 vezes menor e ainda prazo de cinco anos sem juros" (KAWAI: 2000: 129). 


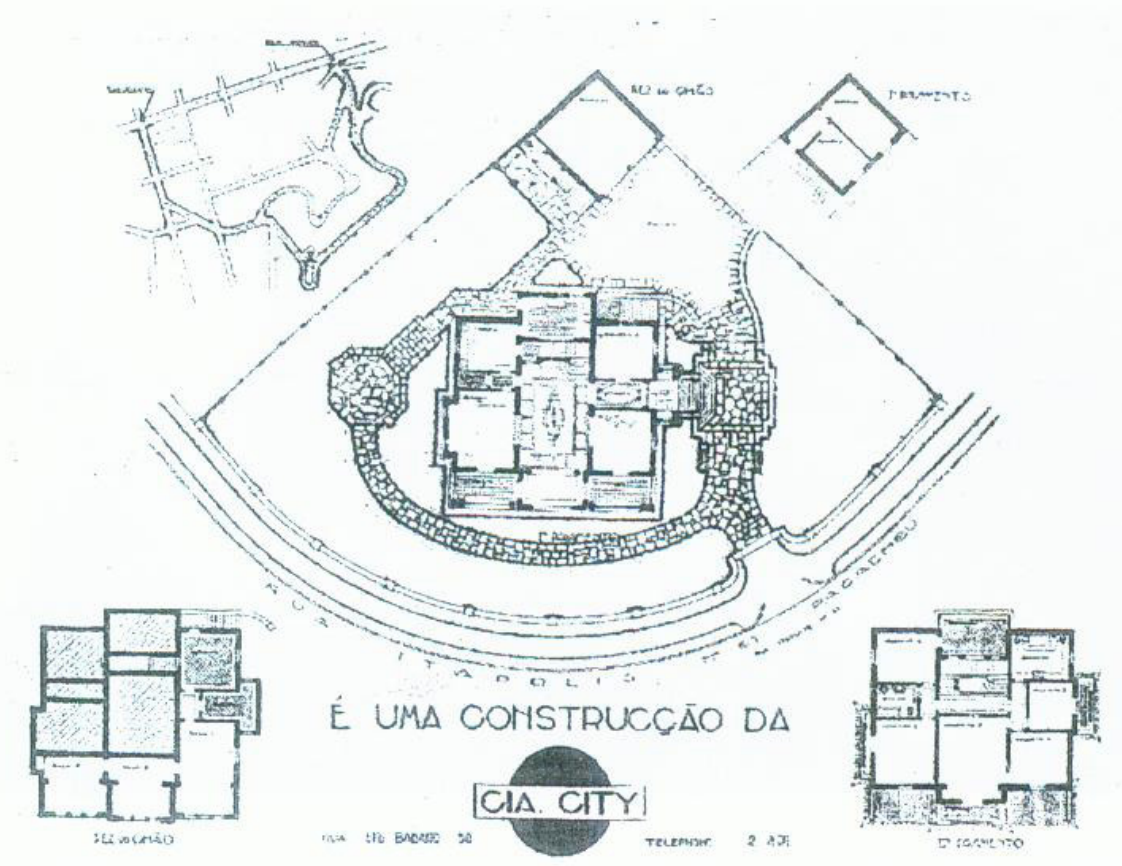

Figura 36: residência construída pela Cia. City no Jardim América com o objetivo de divulgar o padrão arquitetural cobiçado para o bairro. Chama atenção a implantação no centro do lote demarcado por cercas vivas de baixa estatura que possuíam a intenção de gerar visibilidade e arejamento, algo que será almejado nos bairros da região sul de Ribeirão Preto que foram tombados como zona residencial. Fonte: ANDRADE: 1998:

Para Adriana Silva (2004), os loteamentos da zona sul de Ribeirão Preto haviam sido inspirados naqueles primeiros bairros-jardins construídos pela Cia. City em São Paulo. O Jardim Europa, loteado em São Paulo, em 1928, imitando o modelo de seu vizinho Jardim América, e divulgado comercialmente como garden-cities, inicia esse processo de imitação do modelo de empreendimento residencial inaugurado pela Cia. City. Segundo Hugo Segawa (1997), em várias cidades que atravessam processos de aburguesamento semelhantes, os empreendimentos residenciais com requintes de subúrbios-jardins serão reproduzidos caracterizando o crescimento urbano gerado pela riqueza do café.

Marcelo Gaetani (1999) descreve que essas novas formas de morar surgem em Ribeirão Preto ainda sob as noções de salubridade e higiene exigidas pelos Códigos de Posturas Municipais. A moradia passava a ser concebida como refúgio aos problemas urbanos, e os palacetes da Bella Époque cafeeira ainda permaneceriam como o modelo para as novas casas suburbanas. Casas isoladas em meio a um jardim adotando programas que privilegiavam a luz, o ar e os recuos frontais na via pública. A cidade, a partir da construção dos primeiros bairros jardins, passaria a possuir áreas habitacionais destinadas unicamente a uma classe social.

Calil Junior descreve esse processo como a segunda expansão e modernização do centro da cidade de Ribeirão Preto, entre os anos de 1920 a 1940:

Com o crescimento da atividade comercial e as novas edificaçôes resultando numa disputa pelo espaço do centro, ocorre o deslocamento das camadas de alta renda para área localizada ao sul. Esse processo de deslocamento das residências leva a mudança de uso, por exemplo, dos seguintes palacetes localizados no centro: o do Dr. Camilo de Mattos foi ocupado pela Instituição Moura Lacerda e o do 

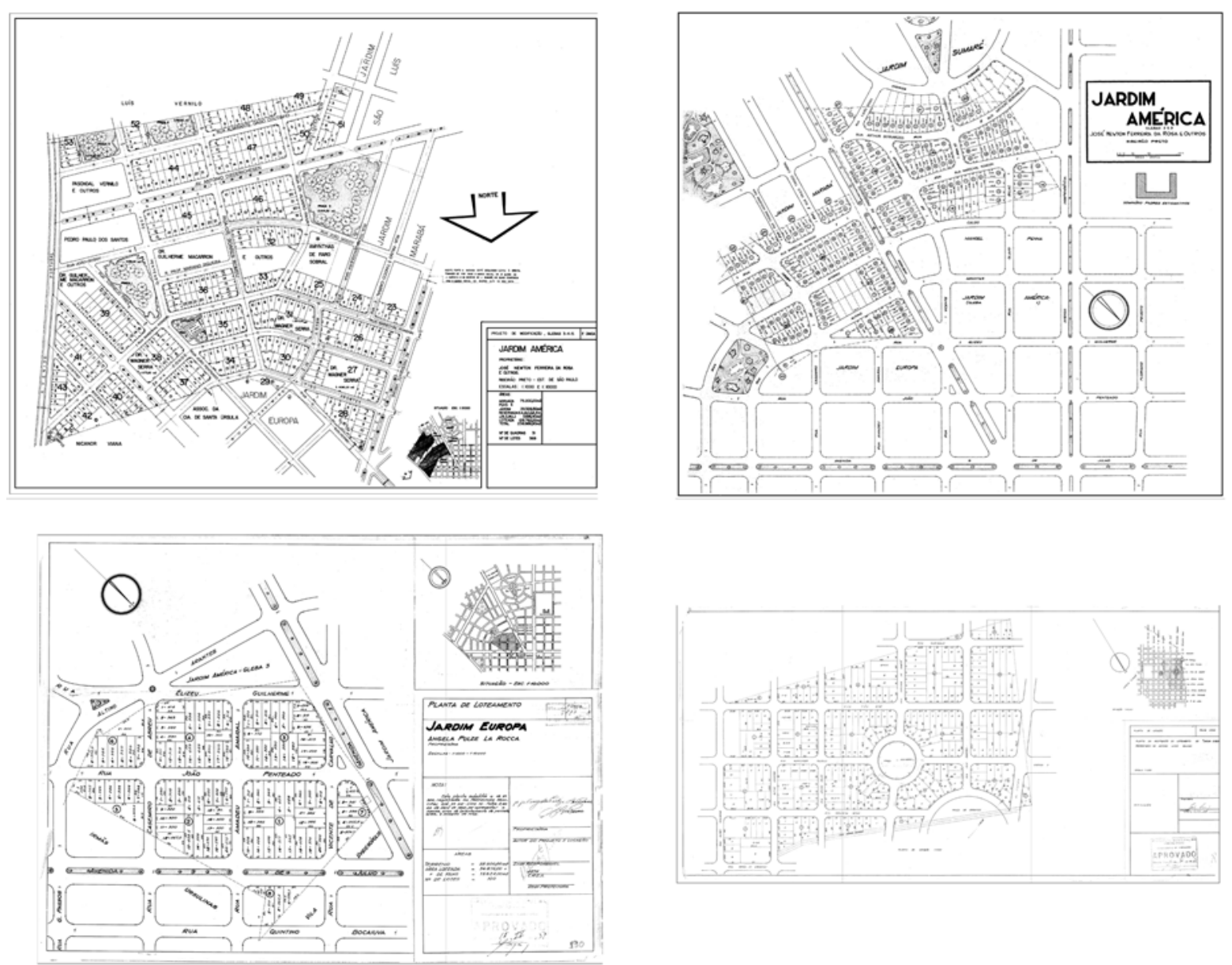

Mapas 22, 23, 24 e 25: os loteamentos realizados por José Newton Ferreira que irão compor o complexo Sumaré - Boa Vista. Fonte: PMRP

Cel. Joaquim Firmino passou a sediar a Faculdade de Odontologia (...). Esse deslocamento responde também às novas exigências, que representam um novo estilo de morar. O bairro Higienópolis constitui essa alternativa de moradia, tendo, como atributos, a proximidade do centro, sua localização nas cotas altas e arborização pela presença de chácaras. Além da proximidade, o bairro é de fácil acessibilidade ao centro, pois o traçado das ruas dá continuidade às vias do centro, mantendo as mesmas dimensões das quadrículas. (CALIL JR: 2003: 79)

O padrão de moradia observado na Vila Higienópolis ou Vila Europa, na década de 1930, posteriormente no Jardim Sumaré, Jardim Eugênia e Alto da Boa Vista, na década de 1940, indicam o modelo de expansão urbana dessa região. A pressão dos seus agentes imobiliários pelo desenvolvimento de obras públicas para tais bairros acontece acompanhando a valorização da terra urbana ainda sob uma noção de salubridade da Primeira República. Ou seja, com base ainda na Teoria dos Meios foi dado privilégio a regiões altas, arejadas e exclusivamente residenciais, longe de fábricas e equipamentos insalubres distantes dos focos de miasmas.

No livro do $1^{\circ}$ Registro de Imóveis da comarca de Ribeirão Preto, consta a escritura do loteamento denominado "Bairro Alto da Boa Vista", registrado no dia 8 de setembro de 1951 pelo seu proprietário, Godofredo Leite Fiusa. A gleba do loteamento também havia sido adquirida pelo retalhamento da Fazenda Santo Antônio do Sumaré, vendida pelo mesmo José Fernandes:

Pelo senhor Godofredo Leite Fiusa, em cumprimento ao disposto do Decreto-Lei Federal n ${ }^{\circ} 58$ de 10 de dezembro de 1937, regulamentado pelo Decreto-Lei no 3.079 de 15 de setembro de 1938, 
me foram apresentados para registro e arquivamento os documentos exigidos pelas citadas leis relativas ao imóvel loteado, situado nesta cidade, constituido de uma parte de terras da antiga Fazenda Santo Antônio do Sumaré, parte essa que o mesmo adquiriu por compra de José Fernandes e sua mulher, conforme transcrição $n^{\circ} 14.628$, de 30 de outubro de 1950, e ficou confrontando com a Estrada de Santa Tereza, com a Estrada de Rodagem Estadual, com José Velludo ou sucessores, com José Newton Ferreira da Rosa, com sucessores de Armindo Paione, com proprietários da Empresa de Força e Luz. de Ribeirão Preto, com Quintino Facci, Cesario Monteiro e José Henrique Faria (CERTID AO: $1^{\circ}$ Registro de Imóveis)

A área global de todo o perímetro do loteamento era de pouco mais de dois milhões de metros quadrados, e o loteador destinava 30\% prescrito pelo Código Arthur Sabóia para os espaços públicos (5\% de áreas livres; e 25\% para ruas e avenidas), constituindo, por fim, pouco mais de 600 mil metros quadrados de áreas públicas dentro do bairro. O espaço de ruas e avenidas fora privilegiado pelo loteador ao exceder em 10\% o que era previsto pelo Código Sabóia. Apesar de ainda prevalecer no Alto da Boa Vista uma grande desproporção entre a porcentagem do loteamento destinado aos parques e recreios (área pública) em relação aos lotes (área privada), a distribuição espacial do bairro se aproximava das prescrições de Anhaia Mello sobre a distribuição de espaços em zonas residenciais. No Boletim do Instituto de Engenheira de setembro de 1933, Anhaia Mello diz que "na questão da subdivisão dos terrenos, a área de espaços abertos públicos ou privados, é fundamental" - estabelecendo que essa distribuição deveria ser feita na proporção de $40 \%$ de espaços abertos públicos (20\% ruas e 20\% parques e recreio) e $60 \%$ de terrenos particulares (3\% para comércio e $57 \%$ para as diversas classes de habitação).

O loteamento do Alto da Boa Vista, entretanto, não estabeleceria diferentes tipos de habitações, o que favoreceu a configuração de um bairro de vizinhanças homogêneas. $\mathrm{O}$ arruamento do bairro se torna alvo de maior cuidado e atenção em virtude da frota de automóvel que os seus moradores mais abastados possuiriam em função de todas as casas abrigarem garagens:

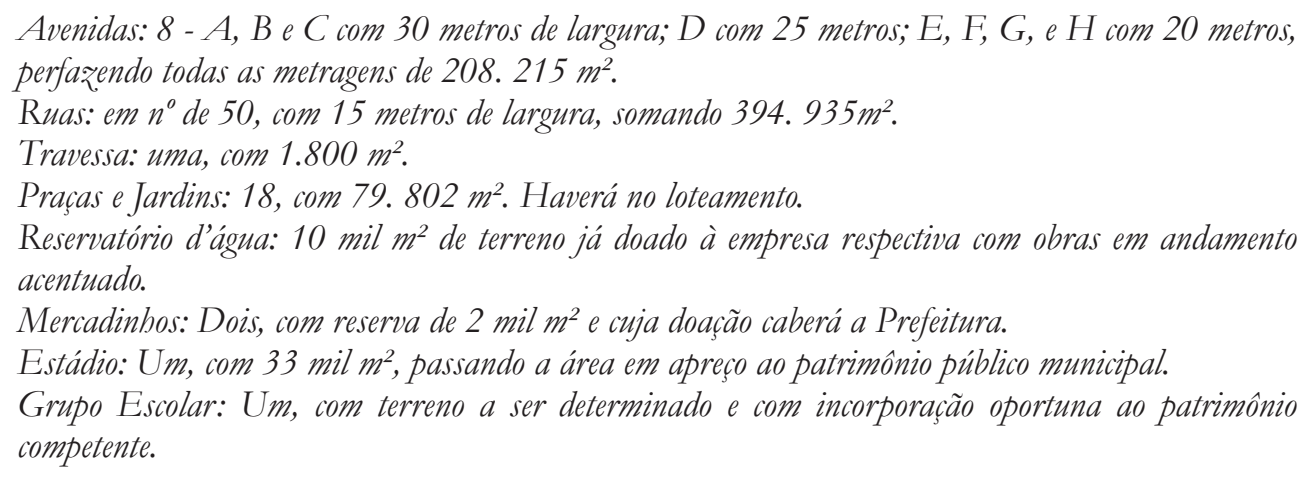

No Esquema do Plano Diretor de Ribeirão Preto, José de Oliveira Reis havia reservado essa região como uma grande área de vegetação, ou um possível bosque para ajudar a controlar as altas temperaturas e as rajadas de ventos. Este novo parque urbano estaria localizado no cume do morro oposto ao Bosque Municipal. O que Oliveira Reis pretendia, era criar nesta área um parque paralelo ao Bosque numa altitude semelhante à bacia oposta ao Morro do Cipó. Todavia, como se viu, essa região reservada pelo urbanista será ocupada pelas residências das famílias mais ricas da cidade.

Os mapas 22 e 23 demonstram o contraste entre a projeção do urbanista e a ocupação 
subsequente pelos bairros-jardins.
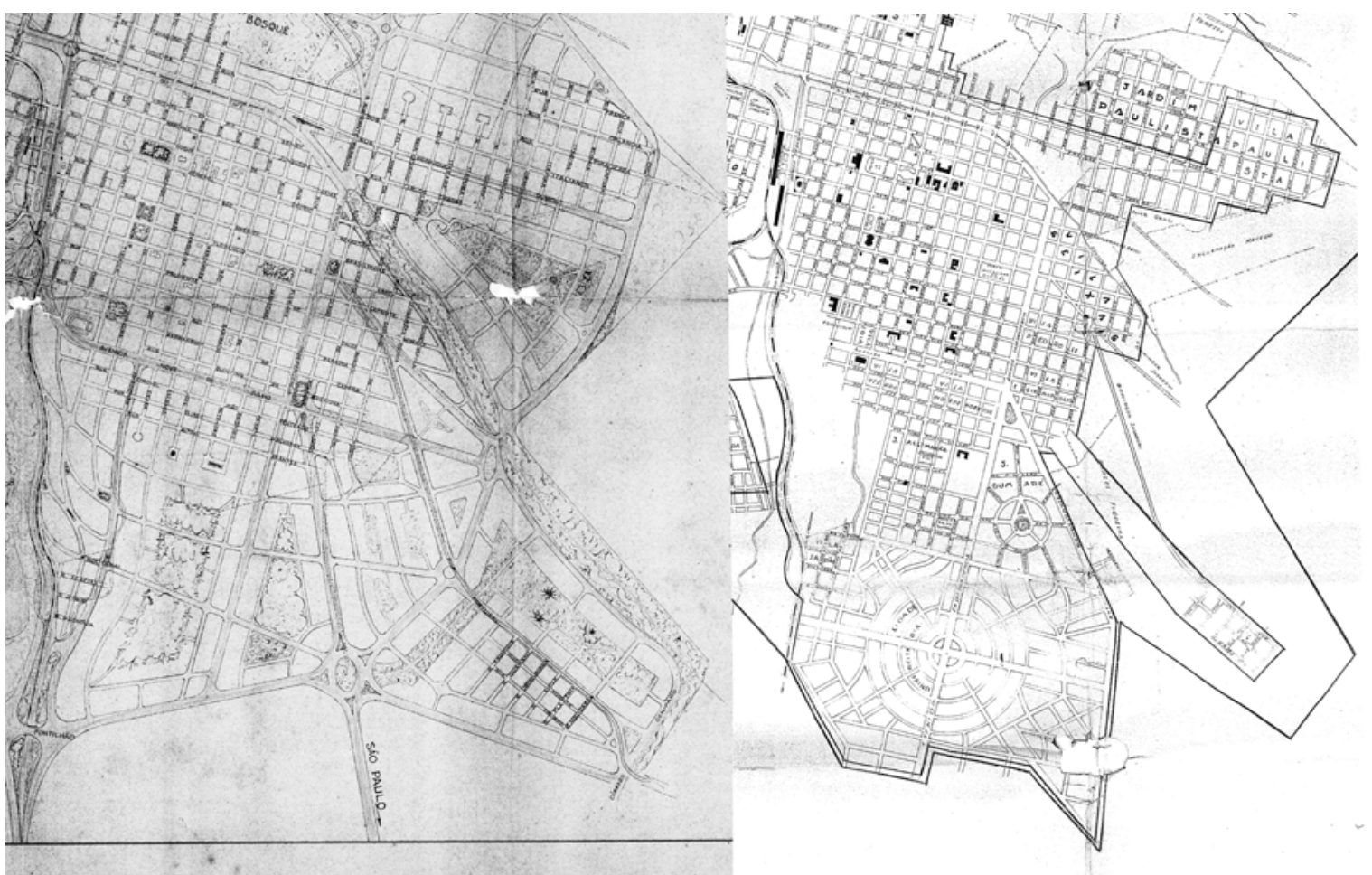

Mapas 26 e 27: demonstração da zona sul segundo as projeções do Plano Diretor de 1945 e como ela foi historicamente ocupado com a reprovação do Plano na Câmara Municipal Fontes: APHRP. 



\section{A ARTE DE SE CONSTRUIR CIDADES EM MEIO À POLÍTICA LOCAL}



O nascimento do urbanismo no Brasil, enquanto uma chave de leitura urbana, esteve relacionado ao aparecimento de ciências técnicas que a partir do crescimento das cidades se debruçaram sobre diversos problemas sociais. A disciplina se associa, nesse sentido, ao surgimento de profissões que tiveram que lidar com inúmeros problemas que envolveram o uso e a ocupação do solo urbano, tanto no desenvolvimento de projetos de abastecimento d'água e rede de esgoto, quanto na elaboração dos zoneamentos típicas de Planos Diretores. Dessa maneira, procuramos nos situar nessa dissertação no trabalho de dois engenheiros que tiveram que enfrentar uma infinidade de questões associadas ao novo arranjo estrutural e institucional das cidades brasileiras durante o século XX, especificamente exemplificadas no caso de Ribeirão Preto.

Ambos os engenheiros urbanistas, Saturnino de Brito e José de Oliveira Reis, ao se debruçarem sobre as questões propostas pela municipalidade de Ribeirão Preto, traziam para cidade os elementos fundamentais do debate sobre o urbanismo do século XX. Como personagens da difusão da urbanística moderna, traziam em suas bagagens a experiência de planos, projetos e relatórios, sistematizados frente aos dilemas do planejamento dos municípios brasileiros.

Ao desembarcar na estação de trens da Cia. Mogiana, em 1912, às margens do Ribeirão Preto, o engenheiro Saturnino de Brito manifestaria suas observações sobre o planejamento urbano da cidade, ressaltando, além de suas considerações técnicas, também o seu posicionamento político:

Antes de passar ao assunto principal, permiti que não perca mais esta oportunidade de dizer o que venho propagando, há annos, em favor da execução e da exploração por administração dos serviços sanitários. Em o $n^{\circ} 11$ (10 de abril de 1912) da Revista de Engenharia, ainda uma vez tratei da questão pedindo para ella a attenção que merece. (BRITO: 1912: 1)

Em seu artigo na Revista de Engenharia, Brito se apresenta como um modesto engenheiro que há anos vinha dedicando seus esforços para que se seguisse no Brasil um roteiro seguro aos trabalhos que intensamente interessavam à vida dos habitantes das cidades do país. Dessa maneira, ele está fazendo referência a uma questão crucial ao urbanismo do século XX quanto aos próprios termos de sua constituição como uma ciência urbanísitca. No capítulo L'art de batir les Villes do livro Le tracé sanitaire des Villes, ele diz, que apesar dos inúmeros estudos com orientação orgânica, sob todas as dimensões - estética, racional e prática -, ainda não se havia chegado às soluções de todos os problemas urbanos. O organismo cidade seria comparável ao organismo homem, sendo, entretanto, algo ainda mais complexo, pois abrangia todos aqueles em seu desenvolvimento devendo 
considerar as condições de cada indivíduo em seu meio ambiente. Em suma, ao urbanismo se impunha o trabalho hercúleo de harmonizar o convívio entre os cidadãos e o seu espaço. A busca pela garantia de melhores influências recíprocas entre o meio cósmico e social seria o mote de uma nova arte de se construir cidades.

José de Oliveira Reis, mais tarde, em 1955, ao também desembarcar em Ribeirão Preto quando retornava ao município após dez anos da elaboração de seu Plano Diretor, retomará, numa palestra na Câmara Municipal, as questões urbanísticas que haviam sido sugeridas por Saturnino de Brito no começo do século XX. Oliveira Reis se incumbia de sensibilizar os vereadores locais para que se definissem os rumos do desenvolvimento da cidade através da aprovação do instrumento urbanístico que ele havia elaborado, assim ele inicia sua palestra:

Comecemos por conceituar o Urbanismo na sua acepção mais moderna na técnica do planejamento. Outrora definia-se o Urbanismo como a arte do planejamento. A preocupação dominante fixava-se no aspecto físico no qual sobressaia-se o efeito artístico, seja paisagístico seja arquitetônico. Os trasados visavam obter perspectivas deslumbrantes, ainda que com sacrifício das condições topográficas (Belo Horizonte) ou jungidos a uma rigidez, ortodoxa do sistema de xadrez, como da nossa cidade (Ribeirão Preto) e de muitas outras.

Essa fase primaria do urbanismo evoluiu expandindo-se alem dos limites da cidade, para o campo, para a região, para o Estado e a Nação e até Nações para se transformar em "URBS" universo - ou "URBANISMO" como propôs Gaston Bardet - extrapolando assim no espaço e no tempo. A conceituação moderna de Urbanismo pode ser encontrada na definição de Thomaz, Adams - urbanista americano - quando dir:

"Urbanismo é a arte de planejar o desenvolvimento das cidades, com objetivo de assegurar saúde, segurança e condiçöes de trabalho aos seus habitantes, prevendo eficientes e convenientes formas de circulação e fomentando o bem estar geral". (REIS: 1955: 1).

Apesar de Oliveira Reis se demonstrar diferente de um urbanismo das Luzes, praticado pelos engenheiros do século XIX, cuja intervenção na organização da natureza seria o objeto central da organização de seus Planos ${ }^{56}$, ele transparecia algo exposto no capítulo de Brito, $L$ 'art de batir les Villes. Ou seja, as interveções urbanas não se desobrigariam de consequências sociais, tanto para o bem quanto para o mal, e as ações práticas deveriam sempres estar imbuídas de uma intenção conciliadora. Porém, sem medir os sacrifícios extraordinários para se chegar a um ideal na relação entre o homem e a cidade: la ville peut rester longtemps malade, assim diante da impossibilidade de se alcançar a harmonia entre a materialidade da cidade e os desejos de seus habitantes, os urbanistas, ao escolher entre ambos - o homem e a cidade -, não poderiam se esquecer que la ville est immortelle e sempre terá um futuro pela frente.

Brito postulava ao longo de seus relatórios elaborados nas primeiras décadas do século XX, que ainda faltariam estudos sob o ponto de vista utilitário, social e artístico para se chegar a um novo regime de planificação urbana. Assim, Oliveira Reis, décadas depois, procura demonstrar que não sacrificaria as condições topográficas do sítio apenas para se chegar a perspectivas deslumbrantes, pois se a planta de Belo Horizonte era composta pela sobreposição de duas malhas em xadrez uma quadriculada e outra em diagonal -, Reis propõe um traçado viário diferente para quebrar a 
rigidez ortodoxa da malha de Ribeirão Preto. O desenho de seu Plano Diretor era mais sinuoso, com as avenidas parkways que acompanhavam as deambulações dos rios pela cidade, além de ruas que evitavam as reticulas em terrenos com grandes declives, o aproximando das concepções de traçado sanitário de Saturnino de Brito.

Em sua palestra, Reis discorre sobre essa arte de se construir cidades:

$$
\text { “ORGANIZAR BEM PARA VIVER MELHOR”. }
$$

Eis aí, em poucas palavras a enorme tarefa que nos cabe a todos, para que possamos, também, usufruir um pouco de uma vida melhor.

$E$ É, pois, planejando que dotaremos a nossa sociedade de meios adequados ao bem estar geral, proporcionando à população condições higiênicas, condicões de segurança, condiçōes de trabalho, condições de segurança, condições de recreação, condições culturais, condições econômicas, condições financeiras, enfim, condições sociais que conduzam à felicidade do homem.

É isso que se propõe o Urbanismo moderno dentro da nova técnica de Planejamento Social. É mais do que dar um bonito plano de cidade no papel e cuja realização muitas vezes fica na aspiração. Vê-se então que a "arte de construir cidade" na sua restrita concepção foi hoje ultrapassada para abranger todo o município e, ir além, estendendo-se por toda a região ecológica. (REIS: 1955: 2)

O urbanismo tem como um de seus paradigmas o vínculo entre o discurso científico e o progresso social, ou entre os saberes sobre a cidade e um projeto progressista de racionalização. A partir da percepção de desordem e caos, a ciência se ocupará de recolocar as coisas em seus lugares e instaurar uma nova ordem espacial, como meio e resultado de uma nova ordem social. Entretanto, a estratégia de afirmação do urbanismo passou em muitos países pela penetração dos profissionais urbanistas nas administrações locais e centrais do Estado. Dessa maneira, a feição das instituições estatais no momento daquela penetração é crucial para existência e efetividade dessa ciência urbanística.

Ao longo da dissertação, vimos quais eram as possibilidades dos profissionais atuarem no âmbito das instituições governamentais do município de Ribeirão Preto. A relação entre estes novos especialistas do espaço urbano e a tutela institucional da cidade ocorreu numa oscilação entre a autonomia dos profissionais, expressando uma posição crítica aos poderes locais instituídos e ao desenvolvimento desorganizado da cidade, e a apropriação pelos políticos locais de fragmentos dos planos e relatórios dos urbanistas, dotando decisões enviesadas pelos interesses oligarcas com as etiquetas de credibilidade que os nomes dos urbanistas conferiam.

Durante o ciclo cafeeiro, a utilização para o uso doméstico das “águas de fontes”, tidas como mais puras, se torna um signo de diferenciação aos fazendeiros, restando aos colonos a utilização de águas dos córregos mais próximos de suas habitações. A construção do abastecimento d'água no núcleo urbano, restrito à área central e mantida através da captação daqueles pequenos mananciais, faz com que persista na cidade um imaginário negativo em relação às águas dos rios, poluídos à vista de todos, sendo o manancial dos desfavorecidos que os dividiam com o uso predatório de indústrias e fábricas.

Mesmo uma Comissão Especial sobre a qualidade das águas, com alguns vereadores 
propondo outro modelo de abastecimento e a encampação da Empresa de Água e Esgotos, além dos pareceres de engenheiros sanitaristas alegando a possibilidade de captação de águas dos rios, não impedem a realização de um acordo que garantiu os negócios da família Silva Prado na região. O descarte da captação dessas águas demonstra uma aliança política entre a Empresa de Águas e Esgotos e o poder municipal, algo que desnuda os interesses econômicos de famílias aristocráticas por trás da apropriação de recursos hídricos transformados em serviços urbanos.

Durante a Era Vargas veremos, por sua vez, os interesses dos loteadores, que acumulavam capital através da especulação imobiliária, prevalecerem sobre a delimitação do Plano Diretor como um instrumento urbanístico de regulamentação do uso e ocupação do solo urbano. Um veto do prefeito interino, além de indícios de corrupção entre os funcionários do Departamento de Engenharia do município, promoveram o desmantelamento da Comissão Especial do Plano Diretor da Cidade.

Vemos, portanto, que as proposições de ambas as peças urbanísticas - Abastecimento d'água de Ribeirão Preto e Observações e Notas Explicativas do Esquema do Plano Diretor de Ribeirão Preto -, não prevaleceram sobre os interesses locais no processo da produção material da cidade, sobrepondo a reiteração dos dois urbanistas em deixar à cidade um tratamento especial no que se refere à qualidade e a ocupação das águas e do solo do espaço urbano. Na medida do crescimento industrial e demográfico das cidades, o desenvolvimento de formas de controle da natureza das águas e do solo se tornam central para a vida urbana moderna e, a partir do século XIX, esse aspecto da relação entre o homem e a natureza será, cada vez mais, mediado por saberes e equipamentos tecnológicos.

No Brasil, tais intervenções se inseriram nesse contexto de elaboração de planos urbanos por profissionais formados, principalmente, nas escolas de engenharia. Os Planos se inserem, portanto, no contexto de mudança das paisagens urbanas brasileiras ao longo do século XIX, com a eliminação das várzeas dos rios através de obras retificações e drenagens, além da extensão de sua ocupação urbana. A água e a terra sempre foram elementos essenciais na relação do homem com a natureza, a sua localização e utilização, desde as civilizações mais antigas, esteve relacionada ao processo de assentamento humano durante a formação das primeiras cidades. Ao longo do tempo, se construíram diversas formas de apropriação desses recursos naturais por diferentes saberes relacionados ao planejamento urbano. Como aponta André Guillerme (1990), o território longo da história não foi dada como algo natural, mas sempre pensado como um artifício através de seus usos. $^{57}$

A progressiva mediação tecnológica no cotidiano das pessoas favoreceu, entretanto, a um processo de distanciamento dessa relação entre o homem e a natureza. O legado desse planejamento foi a quase extinção da presença das águas de superfície urbana, além de uma ocupação irrestrita e mercadológica do solo não só das cidades, mas de territórios imensos. A criação de uma gama de artefatos diminuiu muito a percepção humana destes bens - terra e água - como recursos naturais 
fundamentais a vida.

O tratamento do solo e dos mananciais de Ribeirão Preto ao longo século XX nos permitiu pensar a construção de sua paisagem urbana ${ }^{58}$. Nesse período se iniciou um processo de apropriação desses recursos naturais marcados tanto pela exclusão dos rios como fontes mananciais ${ }^{59}$, quanto pela ocupação irrestrita dos terrenos da cidade. Assim, o tratamento urbano de Ribeirão Preto pareceu possuir como mote a simples desobstrução de obstáculos para apropriação daqueles recursos naturais como um negócio lucrativo.

A relação entre o solo e os recursos hídricos havia sido algo essencial para a formação da cidade de Ribeirão Preto. Primeiro, durante o século XIX, com a ocupação de posseiros nos fundos de vale e, posteriormente, ao longo da Primeira República, com a canalização dos seus rios e a construção do seu sistema de abastecimento d'água e esgotamento sanitário. O próprio traçado das tubulações da rede de água e esgoto, e os canais e avenidas sobre os leitos dos rios, chegaram a definir a forma urbana de Ribeirão Preto, marcada por uma desigualdade material entre os seus lados sul e norte.

As polêmicas sobre o abastecimento d'água em Ribeirão Preto remontam a um dilema que perdurou na cidade ao longo das décadas de 1940 e 1950. Quanto o engenheiro Saturnino de Brito propôs que o abastecimento da cidade não fosse realizado apenas pelos mananciais de "água pura", ele levanta uma questão que seria posteriormente retomada pelo urbanista José de Oliveira Reis. Em suma, quando as fontes no interior de fazenda foram privilegiadas para abastecimento d'água, a cidade vira as costas para os rios de seu perímetro urbano, num movimento de quantificação e monetarização à revelia dos problemas gerados pelas canalizações, represamento e ocupação das várzeas dos rios. Oliveira Reis tentaria impedir essa movimento ao estabelecer em seu Plano Diretor um tratamento mais delicado das várzeas dos rios urbanos.

Porém, com a reprovação do Plano Diretor na Câmara Municipal, além de terem suas margens bastante ocupadas pela cidade, os rios serão relegados apenas a integrar o sistema de esgotamento de água servida e ao escoamento das águas de chuva, o que não exigiu um cuidado artístico, bastante defendido por Saturnino de Brito e José de Oliveira Reis, em trabalhos que envolvessem a proteção das margens dos rios, além da beleza da constituição dos seus canais. A partir de então, não importará à cidade que as suas águas se comportem de maneira natural, ou melhor, interessará as tarifas de água para aumentar o capital da Empresa concessionária, ou ainda o adensamento urbano para se extrair capital com a venda de lotes de terras. Assim, tanto na Primeira República, ao se descartar as águas do ribeirão Preto e do rio Pardo como fontes

58 Sobre os diversos significados políticos, sociais e culturais no entendimento do conceito de paisagem ver SILVESTRE, Graciela. Paisaje y representación. Prismas. No3, 1999, pp. 231-245; e CORRÊA, R. L. Denis Cosgrove - a paisagem e as imagens. Espaço e Cultura. UERJ, RJ, N.29, p.7-21, jan/jun de 2011.

59 A posição privilegiada da cidade sobre o aquífero guarani permitiu ao longo dos últimos 30 anos à construção de um sistema de distribuição completamente dependente da captação das águas subterrâneas. Esta situação levou a cidade a virar as costas aos rios que a entrecruza, que outrora lhe servira como mananciais. A pequena bacia hidrográfica do rio Preto sobre a qual a cidade se assentou está, cada vez mais, modificada, oprimida e controlada por um sistema de canalização e proteção contra enchentes. 
mananciais, quanto durante a Era Vargas, ao ser reprovado o sistema de áreas livres nas várzeas dos rios, perseverou na cidade uma percepção achatada das possibilidades de usufruto de sua bacia hidrográfica.

De maneira lamentável vimos se remontar uma história do fracasso do urbanismo frente aos interesses locais. O repertório dos urbanistas foram postos em Ribeirão Preto diante do crescimento da cidade e dos interesses políticos no município, contudo, a revelia das proposições de Saturnino de Brito e José de Oliveira Reis, se impuseram na consolidação da forma da cidade, primeiro a força política e econômica da Empresa de Força e Luz e, segundo, a vontade também política e econômica da especulação imobiliária de Ribeirão Preto. 




\section{FonTES}

\section{Periódicos.}

REVISTA DE ENGENHRIA. Publicação mensal de Engenharia Civil e Industrial, Architetura e Agronomia. Vol.1, nº 11, São Paulo, 10 de abril de 1912.

BRZIL MAGAZINE. Ribeirão Preto, Le Pays du Café. Revista Periódica e Illustrada d'Arte e Actualidade. Publicação de Propaganda Brazileira no Estrangeiro, 1911.

O BRASIL ILLUSTRADO. Comercio, Industria e Agricultura. Guido F. Colombo. Rio de Janeiro, 1922.

Jornal A CIDADE. Anno VII, sexta-feira, 31 de março de 1911.

Jornal A CIDADE. Anno IX. Edição de Sábado. Dia 3 de maio de 1913.

\section{Relatórios dos Intendentes Municipais e da Comissão de Saneamento do Estado} de São Paulo.

AESP. Relatório da Comissão de Saneamento do Estado São Paulo. Alfredo Lisboa. Tipografia l'etoile du sul, Rio de Janeiro, 1897.

APHRP. Relatório do Major Dr. Joaquim Estanislau da Silva Gusmão, Intendente Municipal, apresentado à Câmara Municipal no dia 7 de janeiro de 1897.

APHRP. Relatório do Dr. Joaquim Alfredo de Siqueira, Intendente Municipal, apresentado à Câmara Municipal no dia 7 de janeiro de 1902.

APHRP. Relatório do Dr. Manoel Aureliano de Gusmão, Prefeito Municipal, apresentado à Câmara Municipal no dia 10 de janeiro de 1903.

APHRP. Relatório do Dr. Floriano Leite Ribeiro, Prefeito Municipal, apresentado à Câmara Municipal no dia 7 de janeiro de 1905.

APHRP. Relatório do Dr. J. P. da Veiga Miranda, Intendente Municipal, apresentado à Câmara Municipal no dia 7 de janeiro de 1909.

APHRP. Relatório de João A. Meira Junior, Presidente da Câmara, apresentado à Câmara Municipal no dia 15 de janeiro de 1920.

APHRP. Relatório de Joaquim Macedo Bittencourt, Intendente Municipal, apresentado à Câmara Municipal no dia 15 de janeiro de 1920.

APHRP. Relatório de Joaquim Camillo M de Mattos, Intendente Municipal, apresentado à Câmara Municipal no dia 15 de janeiro de 1930.

APHRP. Relatório de Eduardo Leite Ribeiro, Prefeito Municipal, apresentado ao Interventor Federal no dia 27 de dezembro de 1931. 


\section{Periódicos.}

REVISTA DE ENGENHRIA. Publicação mensal de Engenharia Civil e Industrial, Architetura e Agronomia. Vol.1, no 11, São Paulo, 10 de abril de 1912.

BRZIL MAGAZINE. Ribeirão Preto, Le Pays du Café. Revista Periódica e Illustrada d'Arte e Actualidade. Publicação de Propaganda Brazileira no Estrangeiro, 1911.

O BRASIL ILLUSTRADO. Comercio, Industria e Agricultura. Guido F. Colombo. Rio de Janeiro, 1922.

Jornal A CIDADE. Anno VII, sexta-feira, 31 de março de 1911.

Jornal A CIDADE. Anno IX. Edição de Sábado. Dia 3 de maio de 1913.

\section{Relatórios dos Intendentes Municipais e da Comissão de Saneamento do Estado} de São Paulo.

AESP. Relatório da Comissão de Saneamento do Estado São Paulo. Alfredo Lisboa. Tipografia l'etoile du sul, Rio de Janeiro, 1897.

APHRP. Relatório do Major Dr. Joaquim Estanislau da Silva Gusmão, Intendente Municipal, apresentado à Câmara Municipal no dia 7 de janeiro de 1897.

APHRP. Relatório do Dr. Joaquim Alfredo de Siqueira, Intendente Municipal, apresentado à Câmara Municipal no dia 7 de janeiro de 1902.

APHRP. Relatório do Dr. Manoel Aureliano de Gusmão, Prefeito Municipal, apresentado à Câmara Municipal no dia 10 de janeiro de 1903.

APHRP. Relatório do Dr. Floriano Leite Ribeiro, Prefeito Municipal, apresentado à Câmara Municipal no dia 7 de janeiro de 1905.

APHRP. Relatório do Dr. J. P. da Veiga Miranda, Intendente Municipal, apresentado à Câmara Municipal no dia 7 de janeiro de 1909.

APHRP. Relatório de João A. Meira Junior, Presidente da Câmara, apresentado à Câmara Municipal no dia 15 de janeiro de 1920.

APHRP. Relatório de Joaquim Macedo Bittencourt, Intendente Municipal, apresentado à Câmara Municipal no dia 15 de janeiro de 1920.

APHRP. Relatório de Joaquim Camillo M de Mattos, Intendente Municipal, apresentado à Câmara Municipal no dia 15 de janeiro de 1930.

APHRP. Relatório de Eduardo Leite Ribeiro, Prefeito Municipal, apresentado ao Interventor Federal no dia 27 de dezembro de 1931.

\section{Pareceres, ofícios e correspondência sobre o abastecimento d'água de Ribeirão} Preto.

APHRP. Oficio de Flávio Mendonça Uchoa. Diretor da Empresa de Águas e Esgotos, 
1911.

APHRP. Discurso de J. P. da Veiga Miranda na Câmara Municipal como membro da Comissão Especial sobre o Abastecimento d’água, 14 de março de 1912.

APHRP. Parecer do Engenheiro Francisco Saturnino Rodrigues de Brito. O Abastecimento d'água de Ribeirão Preto. Estado de São Paulo. 1912.

APHRP. Memorial apresentado a Câmara Municipal de Ribeirão Preto pelo Engenheiro Civil H. G. Pujol Jr, São Paulo, 5 de Dezembro de 1913.

\section{Códigos de Posturas.}

Código de Posturas de Ribeirão Preto. Tip. A vapor do "Diário da Manhã": Ribeirão Preto, 1902.

Código de Posturas de Ribeirão Preto. Tip. Livro Verde: Ribeirão Preto, 1921.

Memórias de ruas, estradas e loteamentos.

APHRP. Memorial para abertura da Avenida Nove de Julho, agosto de 1957.

CERTIDÃO, protocolo n524.058, $1^{\circ}$ Registro de Imóveis. Registro do Loteamento denominado Jardim Sumaré.

\section{Plano Diretor, Palestras e correspondência.}

APHRP. Observações e Notas Explicativas do Esquema do Plano Diretor de Ribeirão Preto. Elaborado por José de Oliveira Reis. Rio de Janeiro, 4 de Dezembro de 1945.

APHRP. Notas sobre "Urbanismo e a sua influência no município". Proferida por José de Oliveira Reis. Ribeirão Preto, 8 de agosto de 1955.

Textos, relatórios e pareceres de Saturnino de Brito.

BRITO, Saturnino. Le tracé sanitaire des Villes (1916). In: Urbanismo; traçado sanitário das cidades; Estudos Diversos. Obras Completas de Saturnino de Brito. vol. 20. Imprensa Nacional. Rio de Janeiro, 1944.

Carta ao presidente do $1^{\circ}$ Congresso Pan-Americano de Arquitetos (1920). In: Urbanismo; traçado sanitário das cidades; Estudos Diversos. Obras Completas de Saturnino de Brito. vol. 20. Imprensa Nacional. Rio de Janeiro, 1944.

Notas para o Congresso dos prefeitos de Pernambuco (1918). In: Urbanismo; traçado sanitário das cidades; Estudos Diversos. Obras Completas de Saturnino de Brito. vol. 20. Imprensa Nacional. Rio de Janeiro, 1944.

Os melhoramentos do Rio de Janeiro (1927). In: Urbanismo; traçado sanitário das cidades; Estudos Diversos. Obras Completas de Saturnino de Brito. v. 20. Imprensa Nacional. Rio de Janeiro, 1944.

. As "Favelas"... de Paris (1927). Obras completas de Saturnino de Brito. vol. 20. 
Imprensa Nacional. Rio de janeiro. 1944.

A Água em São Paulo (1911). In: Abastecimento de Águas, parte geral, tecnologia e estatística. Obras Completas de Saturnino de Brito. vol. 3. Imprensa Nacional. Rio de janeiro. 1944.

Campinas - E. de S. Paulo. Diversos. In: Pareceres, primeira parte. Obras Completas de Saturnino de Brito. vol 26. Imprensa Nacional. Rio de Janeiro. 1944.

. O saneamento das cidades do Brasil no centenário da independência - 1922.

Obras Completas. Imprensa nacional. Rio de janeiro.1944. 


\section{REFERÊNCIAS Bibliográficas}

ALVARENGA, Octavio M. Saturnino de Brito. Grandes Vultos da Engenharia Brasileira. Ed.Clube de Engenharia. Rio de Janeiro, 1979.

ANDRADE, Carlos R. M. de. Barry Parker: um arquiteto inglês na cidade de São Paulo. Tese de Doutorado. FAU/ USP, São Paulo, 1998.

A peste e o plano: o urbanismo sanitarista do engenheiro Saturnino de Brito. FAU/USP. São Paulo, 1992.

Projetos e obras do Eng. Saturnino de Brito para Campinas em fins do século XIX. Oculum Ensaios. Revista de Arquitetura e Urbanismo. n.2 (2002), Campinas.

De Viena a Santos: Camillo Sitte e Saturnino de Brito. in: SITTE, C. A construção das cidades segundo seus princípios artísticos. São Paulo: Ática, 1992.

Projetos e estudos urbanisticos do eng. Saturnino de Brito para algumas cidades fuminenses na virada do século: a emergência de um novo saber sobre a cidade. $3^{\circ}$ Seminário de História das Cidades e do Urbanismo. São Carlos, 1994.

ARANTES, Paulo E. O positivismo no Brasil; breve apresentação do problema para um leitor europeu. Novos Estudos CEBRAP. No 21. Julho de 1988, pp. 185-194.

ARASAWA, C. H. Engenharia e Poder: construtores da nova ordem em São Paulo. São Paulo: Alameda, 2008.

ARGAN, G. C. Arte Moderna: do iluminismo aos movimentos contemporâneos. São Paulo: Cia das Letras, 1992.

BACELAR, Carlos de A. P. \& BRIOSCHI, L. R. (orgs) Na estrada do anhanguera: uma visão regional da história paulista. São Paulo: Humanitas, FFLCH/USP, 1999.

BACKES, A. Fundamentos da ordem republicana: repensando o pacto de Campos Sales. Porto Alegre: UFRS, 2004.

BEGUIN, François. As maquinarias inglesas do conforto. Espaço \& Debates. Revista de Estudos Regionais e Urbanos. Ano XI. no 34. 1991.

BERMAN, Marshal. Tudo que é sólido desmancha no ar - a aventura da modernidade. São Paulo: Cia. das Letras, 1986.

BERTONI, Angelo. Saturnino de Brito e a construção do saber urbano no Brasil: entre importações, adaptações e inovações. in: SALGADO, I; BERTONI, A. (orgs.) Da construção do território ao planejamento das cidades. São Carlos: Ed. RiMa, 2010.

BIT'TENCOURT, L. C. O desenho do colonizador. Anais do SHCU, v.1, n.1, 1990.

BRAUDEL, Fernand. Historia e Ciências Sociais. A longa duração. in: Escritos sobre História. 2a . ed. São Paulo: Perpectiva, 1992.

BRESCIANI, Maria S. M. Metrópoles: as faces do monstro urbano (as cidades no século XIX). Revista Brasileira de História. São Paulo. v.5 nº.8/9, set. 1984/abr. 1985, pp. 35-68.

Londres e Paris no século XIX: o espetáculo da pobrez̧a. $2^{\circ}$ Ed. Brasiliense, São Paulo, 1984.

BUENO, B. P.. A cidade como negócio: mercado imobiliário em São Paulo no século XIX. In: FRIDMAN, F. e ABREU, M. Cidades Latino-americanas: um debate sobre a formação de núcleos urbanos. Rio de Janeiro: Casa da 
Palavra, 2010.

BURKE, P. A escola dos Annales (1929-189). A revolução francesa da historiografia. $2^{\circ}$ ed. Unesp, São Paulo, 1992.

CALIL Jr, O. O centro de Ribeirão Preto: os processos de expansão e setorização. Dissertação de Mestrado, EESC/ USP, São Carlos-SP, 2003.

CARVALHO, José Murilo de. Os Bestializados, o Rio de Janeiro e a República que não foi. $3^{\circ}$ ed. São Paulo: Cia das Letras, 1989.

CARDOSO, C. F; VAINFAS, R. Dominios da História: Ensaios de Teoria e Metodologia. Rio de Janeiro: Campus, 1997.

CASTRO, C; FREIRE, A. As bases republicanas dos Estados Unidos do Brasil. in: GOMES, A. de C.; PANDOLFI, D. C.; ALBERTI, V. (org.) A República no Brasil. Rio de Janeiro: Nova Fronteira: CPDOC, 2002.

CAUN, Elaine Cristina. O engenheiro Antônio Soares Romêo e a modernização urbana de Ribeirão Preto nos tempos do café (1913-1923). Dissertação de Mestrado. FHDSS. Franca :UNESP, 2010.

CHALHOUB, Sidney. Cidade Febril, cortiços e epidemias na corte imperial. São Paulo: Cia. das Letras, 1996.

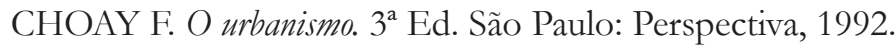

CIONE, Rubem. História de Ribeirão Preto. volume V. 1ªed. Ribeirão Preto: IMAG, 1997.

CORRÊA, Roberto Lobato. Denis Cosgrove - a paisagem e as imagens. Espaço e Cultura. UERJ, RJ, n.29, p.7-21, jun/jun, 2011.

CUNHA, Marcos Vinicius da. O velho estadão. Educação e poder nos anos de ouro do Ginásio Otoniel Mota. Ribeirão Preto: Palavra Mágica, 2000.

DECCA, E. de. O Estatuto da História. Espaço \& Debates. Cidade e História, n³4, 1991.

DOIN, J. E. de M; NETO, H. P.; PAZIANI, R. R.; PACANO, F. A. A Belle Èpoque caipira: problematizações e oportunidades interpretativas da modernidade e urbanização no mundo do café (1852-1930) - a proposta do Cemunc. Revista Brasileira de História. São Paulo, v. 27, n53, p.91-122, 2007.

ENGELS. F. A situação da classe trabalhadora na Inglaterra. Porto: Ed. Afrontamento, 1975.

FARIA, Rodrigo dos Santos. Ribeirão Preto, uma cidade em construção: o discurso da bigiene, beleza e disciplina na modernização Entre Rios (1895-1930). São Paulo: Annablume, 2010.

- José de Oliveira Reis, urbanista em construção: uma trajetória profissional no processo de institucionalização do urbanismo no Brasil (1926-1965/1966). Tese (doutorado). Unicamp. IFCH. Campinas. 2007.

- Desenhando uma nova cidade: Parkways, Neighborhood Unit e Zoning no Plano Urbanístico de Ribeirão Preto do Engenheiro José de Oliveira Reis (1945-1955). DOCOMONO 5, São Calos, 2003.

FELDMAN, Sarah. O zoneamento ocupa o lugar do plano: São Paulo, 1947-1961. Anais do VII Encontro Nacional da ANPUR. Recife, vol. 1, pp. 667-684, 1997.

. Planejamento e Zoneamento: São Paulo (1947-1972). São Paulo: Edusp/Fapesp, 2005.

- A década de 30: dimensão urbano-industrial e (re)construção de saberes e práticas no campo do urbanismo. in: SALGADO, I; BERTONI, A. (orgs.) Da construção do território ao planejamento das cidades. São Carlos: Ed. RiMa, 2010. 
FERRO, Sergio. A casa popular. São Paulo: GFAU, 1987.

FOUCAULT, Michel. Microfísica do Poder. $7^{\circ}$ Ed. Graal. Rio de Janeiro, 1979.

FRANCO, M. S. de C. Homens livres na ordem escravocrata. 4.ed. Unesp, São Paulo, 1997.

GAETANI, Marcelo. Arquitetura residencial no centro de Ribeirão Preto no período de 1915-1945. Dissertação de Mestrado, Universidade Mackenzie, São Paulo, 1999.

GARAVAZO, J.; MARCONDES, R. L. Metamorfoses da economia urbana: os estabelecimentos de um município brasileiro (Ribeirão Preto, 1890-1962), Estudos do Século XX, nº4, 2004.

GARCIA, V. E. Do santo on de quem? Ribeirão Preto: gênese da cidade mercadoria. (tese de doutorado), IAU/USP, 2013.

GERRAND, Roger-Henri. Espaços Privados. in: DUBY, G; ARIÉS, P. História da Vida Privada. Cia. das Letras, v.4, São Paulo, 2009.

GUILLERME, André. Les temps de l'eau. La cité, l'eau et les techniques. Mâcon:Champ Vallon. 1990.

GOMES, Ângela de Castro. A política brasileira em busca da modernidade: na fronteira entre o público e o privado. in: (org) SCHWARZ, Lilia Moritz. História da vida privada no Brasil: contrastes da intimidade contemporânea. Vol.4. Companhia das Letras, 1998.

GOMES, A. de C. O 15 de Novembro. in: GOMES, A. de C.; PANDOLFI, D. C.; ALBERTI, V. (org.) $A$ República no Brasil. Rio de Janeiro: Nova Fronteira: CPDOC, 2002.

HALL, C. Sweet Home. in: DUBY, G; ARIÉS, P. A História da Vida Privada. Cia. das Letras, v.4, São Paulo, 2009.

HARVEY, D. O pós-modernismo na cidade: arquitetura e projeto urbano. In: A condição pós moderna. São Paulo: Edições Loyola, 1992.

HOWARD, E. Cidades-Jardins de Amanhã. 2a ed. São Paulo: Hucitec, 2002.

JAMESON, F. O tijolo e o Balão: arquitetura, idealismo e especulação imobiliária. in: A virada cultural. Rio de Janeiro: Editora Civilização Brasileira, 2006.

LANNA, A. L. D. Santos, uma cidade em transição (1870-1913). (Tese de doutorado) São Paulo: FFLCH, 1994.

LAPA, José Roberto do Amaral. A cidade; os cantos e os antros. Ed. Unicamp, Campinas, 2008.

LEAL, Victor Nunes. Coronelismo, Enxada e Voto; o município e o regime representativo no Brasil. $4^{\circ}$ Edição, São Paulo: Cia. das Letras, 2012.

LEME, Maria Cristina da Silva. A formação do pensamento urbanistico no Brasil, 1895-1965. In Leme, M. C. da S. Urbanismo no Brasil (1895-1965). São Paulo: Studio Nobel; FAUUSP; FUPAM, 1999.

A concepção de cidade e de papel do Estado para os urbanistas paulistas no início do século. Espaço \& Debates. Cidade e História, nº34, 1991.

LEVI, Darrell E. A Família Prado. Cultura 70, São Paulo, 1977.

LIMA, R. de C. F. de. Projetos de Victor Dubugras para Ribeirão Preto. (Dissertação de Mestrado). FAU/USP. São Paulo, 2004.

MARINS, Paulo C. G. Habitação e vizinhança. Limites da privacidade no surgimento das metrópoles brasileiras. in: SEVCENKO, Nicolau (org.) História da vida privada no Brasil. vol.3, São Paulo : Cia. das letras, 
1998.

MARQUES, E. C. Da higiene à construção da cidade: a constituição do setor de saneamento no Rio de Janeiro. Anais do SHCU, v.3, n.1, 1994.

MARX, Murilo. Cidade no Brasil: terra de quem? São Paulo, Edusp/Nobel, 1991.

MARX, K. O Capital. Crítica da economia política. São Paulo: Ed. Nova Cultural, 1996.

MARCONDES, R. L.; OLIVEIRA, J. H. C. Trocando de mãos: o mercado de imóveis rurais em Ribeirão Preto (18741930). Economia e Sociedade. Campinas, v.22, n.1 (47), abr. 2013, pp. 263-285.

MELO, Marcus A. B. C de. Municipalismo, nation building e a modernização do estado nacional no Brasil. Revista Brasileira de Ciências Sociais. vol.8, n.23, out-1993, São Paulo.

MELLO, Rafael Cardoso de. Um "coronel de saias" no interiorpaulista: a "Rainha do Café" em Ribeirão Preto (18961920). Dissertação de Mestrado. FHDSS. Franca: UNESP, 2009.

MONBEIG, Pierre. Pioneiros e fažndeiros de São Paulo. São Paulo, HUCITEC/POLIS, 1984.

MOREIRA, F. D. A formação do urbanismo moderno no Brasil: as concepções urbanísticas do engenheiro Saturnino de Brito. Anais do SHCU, v.1, n.1, 1990.

MORE. Thomas. Utoopia. $3^{\circ}$ Ed. Martins Fontes, São Paulo, 2009.

OLIVEIRA, J. H. C.; MARCONDES, R. L. Negociantes de imóveis durante a expansão cafeeira em Ribeirão Preto (1874-1899). Tempo, Rio de Janeiro, nº15, 2003.

OT'TONI, D. A. B. Cidade-Jardim: formação e percurso de uma ideia. in: HOWARD, E. Cidades-Jardins de Amanhã. $2^{\mathrm{a} e d . ~ S a ̃ o ~ P a u l o: ~ H u c i t e c, ~} 2002$.

KAWAI, C. S. Os loteamentos de traçado orgânico realizados no município de São Paulo na primeira metade do século XX. Dissertação de Mestrado. FFLCH/USP. São Paulo, 2000.

KOSSOY, Boris. Fotografia \& História. 5. Ed. São Paulo: Ateliê Editorial, 2014.

PAZIANI, Rodrigo Ribeiro. Construindo a petit paris: Joaquim Macedo Bittencourt e a belle époque em Ribeirão Preto (1911-1920). FHDSS/Unesp, 2004, Franca. (tese de doutorado em história).

Outras leituras da cidade: experiências urbanas da população de Ribeirão Preto durante a Primeira República. Tempo, Rio de Janeiro, nº19, 2005.

PINHEIRO; E. P; GOMES. M. A. A. de. (org) A cidade como bistória. Os arquitetos e a historiografia da cidade e do urbanismo. Salvador: EDUFBA, 2004.

RESENDE, V.; RIBEIRO, F. de A. A arquitetura e o urbanismo modernos no Distrito Federal, escolha ou consequência na Era Vargas? Seminário DOCOMONO. (versão online, acessado em 19/12/2014: http:// www.docomomo.org.br/seminario\%208\%20pdfs/004.pdf)

RIBEIRO, M. A. R. História sem fim ... um inventario da saúde pública. São Paulo (1880-1930). (tese) Campinas: Unicamp, 1991.

REIS FILHO, Nestor Goulart. Urbanização e modernidade: entre o passado e o futuro (1808-1945). in: MOTA, Carlos G. A viagem incompleta. A experiência brasileira. São Paulo, Senac, 2000.

RONCAYOLO, Marcel. La Ciudad. 1ª Ed. Paidós Ibérica, Barcelona, 1988.

SAIA, L. Morada Paulista. São Paulo: Perspectiva, 1972. 
SALGUEIRO, H. A. (org.) Por uma nova história urbana. EDUSP, São Paulo, 2001.

Cidades capitais do século XIX: racionalidade, cosmopolitismo e transferência de modelos. Edusp, São Paulo, 2001.

Revisando Haussmann. Revista USP. São Paulo (26): 195-205, junho/agosto, 1995.

SALGADO, I. Urbanismo sanitarista em Campinas no final do XIX. Anais da SHCU, Cidade e Urbanismo, 1990.

SCHWARZ, Roberto. As ideias fora do lugar. In: Ao vencedor as batatas; Forma literária e processo social nos inícios do romance brasileiro. São Paulo: Duas Cidades/Ed. 34, 2000.

SEGAWA, Hugo. Arquiteturas no Brasil, 1900-1990. Edusp: São Paulo, 1997.

SEVCENKO, Nicolau. Futebol, metrópoles e desatinos. Revista USP. São Paulo. № 22, pp. 30-37. jun-julago, 1994.

O prelúdio republicano, astúcias da ordem e ilusões do progresso. in: SEVCENKO, Nicolau (org.) História da vida privada no Brasil. República: da Belle Époque à Era do Rádio. Vol. 3. São Paulo, Cia das Letras, 1998.

A revolta da vacina, mentes insanas em corpos rebeldes. $1^{\text {a }}$ Ed. Scipione. São Paulo, 2003.

SHENK, Luciana. Arquitetura da Paisagem: entre o Pinturesco, Olmested e o Moderno. Tese de Doutorado. EESC/ USP, São Carlos, 2008.

SILVA, A. C. B. da. Cem anos de desenvolvimento urbano de Ribeirão Preto. In: ASSOCIAÇÃO Comercial e Industrial de Ribeirão Preto. Ribeirão Preto: Gráfica São Francisco, 2004.

Expansão urbana e formação dos territórios de pobreza em Ribeirão Preto: os bairros surgidos a partir do Núcleo Colonial Antônio Prado (1887). São Carlos: UFSCar, 2008.

SILVESTRE, Graciela. Paisaje y representación. Prismas. No3, 1999, pp. 231-245.

SIMMEL, G. As grandes cidades e a vida do espírito (1903). Mana 11 (2):577-591, 2005.

TELAROLLI JR, R. Poder e Saúde: a república, a febre amarela e a formação dos serviços sanitários no estado de São Paulo. Tese de Doutorado. FCM/Unicamp, Campinas, 1993.

TOPALOV, Christian. Os saberes sobre a cidade: tempos de crise? Anais IV Encontro Nacional da ANPUR, Salvador, 1991.

UNWIN, R. La practica del urbanismo: una introduccion al arte de proyectar ciudades y barrios. Barcelona: Editora Gustavo Gili, 1984.

VALADÂO, Valéria. Memória Arquitetônica de Ribeirão Preto. Dissertação de Mestrado. Programa de Pósgraduação em História. FHDSS/unesp, Franca 1997.

VIANA, Oliveira. Populacõos meridionais do Brasil. Brasília: Senado Federal, Conselho Editorial, 2005.

WALKER, T. W.; BARBOSA, A. de S. Dos coronéis a metrópole, fios e tramas da sociedade e da politica em Ribeirão Preto no século XX. Palavra Mágica: Ribeirão Preto, 2000. 



\title{
Anexos
}

\section{ABASTECIMENTO D'ÁGUA DE RIBEIRÃO PRETO}

\author{
(Estado de S. Paulo) \\ Parecer do Engenheiro F. Saturnino Rodrigues de Brito.
}

\section{INTRODUÇÃO}

Antes de dizer sobre a questão que me foi proposta pela Prefeitura, farei uma sumaria exposição dos serviços.

O abastecimento d'água esteve a cargo da municipalidade até 1903, quando arrendou, por contrato, a Empreza de Águas e Exgotos. Naquele tempo só se dispunha de 300 metros cúbicos por dia e foi preciso reformar e desenvolver a rede, construir reservatórios e fazer novas captações em mananciais cujo caudal deu, durante alguns annos de 4000 a 5000 metros cúbicos diários.

A seca prolongada, que empobreceu outros mananciais, colocou a Empreza na contingencia de tomar outras águas.

De acordo com a Câmara (diz a Empreza em officio do qual me deu cópia), resolveu tomar as águas do Ribeirão Preto, que banha a cidade; a analyse era favorável, mas as condições do curso e o escrúpulo em não do seu poder auto-depurador, indicaram um tratamento purificador: a Empreza decidiu-se pela ozonificação, e mandou vir appparelhos para o tratamento de 2.000 metros diários, no que, aliás, estava de acordo com um grande movimento hygienista em favor deste processo e isto lhe abona o intuito de resolver a dificuldade de um modo satisfactório. As desconfianças do público pelas águas que correm a sua vista recebendo contaminações, venceram a confiança no exitoda purificação, e o poder municipal, segundo relata a Empreza, no louvável empenho de bem servir, a contenda de todos, preferiu que se fizesse a tomada de águas do Rio Pardo.

Não houve exame analytico prévio, na estiagem e na estação das chuvas: a resolução entrou em execução e, mal foram acabados os filtros, urgida pelo prazo do contracto, a Empreza, em estação chuvosa (outubro a dezembro, 1911), distribuiu à cidade água de forte

coloração para completar o volume deficiente dos seus antigos mananciais. Foi o resultado de uma imprevidência de ambas as partes interessadas na boa solução do problema.

A colmatagem rápida dos filtros e o seu fraco poder para clarificar águas tão turvas, conduziu a analyse, a ensaios de laboratório para o tratamento prévio pelo alumem e cal e, finalmente, a consulta com que me honrou a Prefeitura.

Antes de passar ao assunto principal, permitti que não perca mais esta oportunidade de dizer o que venho propagando, há annos, em favor da execução e da exploração por administração 
dos serviços sanitários. Em o no 11 (10 de abril de 1912) da Revista de Engenharia, ainda uma vez tratei da questão pedindo para ella a attenção que merece.

Neste assumpto se torna difficil e delicadíssimo a acção dos poderes públicos das cidade para conciliarem os interesses sanitários e os das emprezas que exploram os serviços, as quaes praticamente, em todos os paizes do mundo, não poderão bem servir se não obtiverem para os capitais empregados a correspondente remuneração, sejam bem ou mal administradas. Só o poder público, colhendo vantagens indiretas dos benefícios prestados, rehavendo em uma verba o que perde em outra, é praticamente capaz de um sacrifício monetário para fazer o que for preciso e para enfrentar as reclamações exageradas e as criticas fáceis dos que systematicamente as manteem em todas as cidades. Não convem, nesta ordem de serviços, dividir as responsabilidades para accudir convenientemente às necessidades públicas: é preferível que se reclame contra as administrações das municipalidades do que das emprezas, porquanto se poderá com mais justiça julgar do fundamento das reclamações e o próprio público poderá com maior facilidade corrigir o mal, se quizer intervir com melhor critério político na gestão dos negócios municipais.

Repetindo, nesta exposição, a These que venho propagando em varias livros relatórios e artigos de imprensa, claro está que viso unicamente formar opiniões para um outra orientação no termo do contracto de arrendamento (se até lá puder perdurar nos espíritos dos que me lerem o meu fraco appelo): porque, no caso concreto actual, existindo a empreza, a situação está criada e entregue ao critério da administração municipal para resolver as difficuldades como entender ser de necessidade

justiça, e neste sentido se a vê agir em Ribeirão Preto, conforme deprehendo do que ouvi e concluo do louvável desejo da Prefeitura e da Empreza em corrigirem a situação do abastecimento d'água.

\section{VOLUME NECESSARIO E VOLUME DISTRIBUÍDO.}

A cidade tem cerca de 3.000 casa o que corresponde á população de 18.000 habitantes. A empreza distribue água em 2.400 casas, sendo a Penna d'água de 1.500 litros diários para 2.140 casas e de 2.000 litros para 260 casas: total, só para o serviço domiciliário, $3.730 \mathrm{~m}^{3}$ diários.

Tomando 20.000 habitantes, o volume necessário para todos os serviços, públicos e particulares, pode ser limitado a 4.000 metros cúbicos por dia, a razão de 200 litros por habitante.

Nesta quota comprehendemos as perdas, os usos extraordinários de alguns, o serviço de algumas indústrias. Certas indústrias, de maior consumo, não devem tomar água de distribuição: o preço deve ser proibitivo, porquanto facílimo lhes é se proverem no ribeirão que banha a cidade. As indústrias, porém que incorporam água à alimentação, devem tomar água potável para a parte do serviço que interessa a saúde pública, seja da distribuição, seja de outra fonte provadamente "imaculada e imaculável”, na phrase do eminente dr. Imbeaux.

A quota para os serviços domiciliários (tomando o dobro do que o dr. F. Bicalho reconhece ser bastante) será de 100 litros por dia e por habitante, para uma distribuição liberal: teremos, então, 600 litros por habitação. Ora, se dermos a cada habitação 1000 litros, teremos uma excellente distribuição, desde que todos os outros elementos do serviço ocorram para assegurar o bom funcionamento.

A Empreza dispõe de $2.500 \mathrm{~m}^{3}$ diários de água de fonte, na estiagem: em rigor faltam-lhe apenas $1.500 \mathrm{~m}^{3}$ para bem suprir a cidade. Attendendo, porém, á previsão do rápido desenvolvimento, e tomando $6.000 \mathrm{~m}^{3}$ para o serviço, temos que faltam $3.500 \mathrm{~m}^{3}$ a tomar do Rio Pardo. 
Assim julgada a situação, e attendendo ao grande caudal do Rio Pardo, reconhecemos que elle é excellente quando ao volume disponível. Com

[f1.4]

effeito, além dos $2.500 \mathrm{~m}^{3}$ de água de fonte em estiagem, o programa, pela consulta que se me fez, é dispo de $6.000 \mathrm{~m}^{3}$ de águas tomadas do Rio Pardo.

Mostramos que, mesmo tomando as quotas excessivas acima mencionadas a Empreza despois de $3.730 \mathrm{~m}^{3}$ diários para o serviço domiciliário, ou sejam cerca de $6.000 \mathrm{~m}^{3}$ para todos os serviços: portanto bastaria tomar do Rio Pardo:

$(6.000-3.730)+(3.730-2.500$ (fontes) $)=3.500$.

Comparando este resultado com o acima achado, para um serviço normal, vê-se que chegamos ao mesmo valor com uma diferença: - acima achamos que bastaria tomar do Rio Pardo $3.500 \mathrm{~m}^{3}$ para a actualidade e para prever o futuro próximo: - agora achamos que será preciso tomar $3.500 \mathrm{~m}^{3}$, só para a actualidade e, então, pretende-se tomar $6.000 \mathrm{~m}^{3}$ para prever o futuro, ou talvez, para acudir as demandas de consumo.

Porque este exagero? Elle não resulta somente das bases excessivas tomadas para a distribuição domiciliária: elle provém também do systema de distribuição por meio de pennas (lentilhas hydrométricas), sem caixas domiciliarias e estando a população habituada ao franco desperdício, conforme vericamos e para isto chamamos a vossa attenção.

Pouco importa ser uma Empreza a concessionária do serviço: direi mesmo que pe esta situação mais um motivo para me dizer a verdade e para se empenhar a administração municipal na justa economia dos serviços, porquanto (repetindo o que temos dito), serviços não remunerados, e porque se abuse no consumo, gastando água inutilmente, conduz a prejuízos para o próprio público.

Fallando desassombradamente a verdade, pouco importa que ella aproveite a Empreza: acima de tudo aproveita a cidade.

Se esta situação de disperdício no consumo é inconveniente nas adducções por gravidade, muito mais onerosa se torna nas adducções por elevação mecânica, como em Ribeirão Preto, com as águas do Rio Pardo. Se se não cuidar de regularisar o consumo, seja embora caudalosa a fonte, a muncipalidade pagará mui cara a inadvertência, quando os serviços ficarem a seu cargo, o que sucederá no futuro. Esperar por

[fl.5]

esta ocasião, será consolidar e desenvolver o habito do desperdício.

Por ahi se vê que sou francamente favouravel ao uso do hydrometro, de acordo com as mais autorizadas opiniões dos que sabem conciliar as conclusões praticas com as aspirações theoricas.

Seja ou não acceito o meu alvitre pela Municipalidade e pela Empreza, penso que não podem e não devem deixar de concordarem em medidas que regularizem o consumo, limitando o desperdício nos serviços públicos e nos particulares.

\section{II - QUALIDADE E TRATAMENTO DAS ÁGUAS.}

A água dos pequenos mananciais - chamada "água de fonte" -, é tida e havida como de primeira qualidade por todos na localidade. Não examinamos a localidade, mas devemos dizer que 
se não deve dormir em descanço sobre águas que sejam imaculadas em sua origem mas que possam se maculadas pelas habitações a montante da captação, pelos visitantes, pelos próprios guardas do serviço. Convém as Prefeituras se não descuidarem de exercerem ahi uma fiscalisação garantidora da pureza, tanto mais necessária por ser reduzido o caudal dos mananciais.

A água do Rio Pardo, em caudal abundante, atravessa uma grande extensão de margens alagadiças e paludosas, de onde a ausência de habitações. A falta de contribuição orgânica de origem animal nas margens, em longo percurso, é uma vantagem infelizmente em parte neutralizada pelas condições paludosas de terrenos alagados durante a estação das chuvas, as quais lentamente esgotam as suas águas durante a vasante. Devemos também não esquecer que, si as margens do rio só são habitadas muitas dezenas de kilometros a montante da colheita das águas para o abastecimento de Ribeirão Preto, o mesmo não sucede com os seus affluentes, onde existem importantes estabelecimentos de café, com as suas numerosas casas de operários. Confiando, entretanto, na auto-depuração para a situação actual, attribuiremos a matéria orgânica encontrada pelas analyses o valor de proveniência vegetal, mas devemos proseguir nas analyses, annos a seguir, porquanto qualquer augmento notável na carga orgânica parecerá de origem suspeita como animal.

[fl. 6]

Para ter uma ideia precisa do valor da observação que faremos, lembremos o vale embrejado do córrego Palmeira, pouco a montante da colheita de águas da Empreza e situado na mesma margem.As águas deste córrego são claras, e d'ahi a lembrança de mudar para lá a tomada do abastecimento: a analyse condenou estas águas, pela forte carga orgânica, certamente de origem vegetal, preferindo as águas turvas do Rio Pardo. do Estado:

Esta situação indica dupla medida, uma preventiva, outra corretiva, ambas da competência

$1^{a}$ a lei de proteção do cursos, para a necessidade da qual apppelamos no estudo sobre o Abastecimento d'água de S. Paulo.

$2^{\mathrm{a}}$ o saneamento agrícola das margens do Rio Pardo e seus affluentes drenando esta superfícies, certamente ubérrimas, e as cultivando. É possível que este serviço de drenagem e de cultura seja minimamente indicado para os lavradores joponezes, procurando garantir-lhes a vida durante a phase de trabalho saneador. Para o Estado há o grande proveito industrial de desenvolver outras culturas, garantindo dos accidentes depreciadores da sua grande lavoura de café.

Para outro lado, compete á Empreza a purificação das águas de acordo com os processos que a técnica indica, tanto para clarificação como para a nitrificação da carga orgânica, no grau em que se toma necessário, caso o Estado descuide de executar as medidas acima indicadas.

As águas do Rio Pardo são turvas: na occasião da nossa visita (maio), oseu aspecto nada tinha de extraordinário, e outros rios existem com águas excellentes e mais turvas, mas de fácil correctivo. As informações que temos, confirmadas pela Empreza, chamam a attenção para uma fortíssima turbidez durante a estação das águas, sendo a argilla colloideal de difficílima decantação e exigindo o emprego de uma dose mais forte de cal e de alumem para a coagulação.

Ora, a situação existente, com os trabalhos executados, e a própria consulta que se me faz, conduzem a admittir que outra solução não haja, ou melhor, que tomemos o caso com o de uma cidade que tivesse outro recurso que não o suprimento no Rio Pardo. Encaremos, portanto, o problema por este aspecto definitivo para o resolver de um modo seguro.

As analyses feitas anteriormente e as que fisemos repetir (ver anexos) não contra-indicam o uso destas águas, convenientemente purifica-

das da turbidez e da matéria orgânica, no grau em que preciso for, conforme a estação e o critério analytico que se tornará obrigatório no correr dos serviços de abastecimento. 
Se a coloração fosse grau elevado e de origem vegetal, a difficuldade seria maior e ter-se-ia de recorrer a doses muito mais elevadas de agentes chimicos. Bastará dizer que para tirar a cor de grau 100 é preciso empregar cerca de 34 gr. de alumem. Em New Orleans verificou-se necessário tratar a água de poços profundos com $171 \mathrm{gr}$. para tirar por completo a cor de grau 150 a 350, ou 34,2 gr. si se neutralizar previamente a água: vê-se que o caso de descorar águas subterrâneas é geralmente mais difficil que o de descorar águas superficiais.

Felizmente as analyses mostram que as águas do Rio Pardo são simplesmente turvas.

O grau de turbidez e a sua natureza excluem a prática da simples clarificação pelo repouso. Também ficou provado que a filtração feita pela Empreza é insufficiente, a não ser empregando uma grande superfície e uma Camada muito mais espessa e com penosos trabalhos de retirada de lama depositada.

É preciso recorrer a alcalinização prévia, pelo cal, e a coagulação pelo sulfato de alumínio (alumem) preparando para este uso, porque o baixo grau de alcalinidade das águas do Rio Preto [Pardo] não permitte a reação chimica efficiente sem aquelle corretivo. Este tratamento se faz misturando os ingredientes com a água na dosagem que for determinada: a mistura deve se comppleta e convém ser automática. Depois procede-se a decantação e a filtração, porquanto aquella prieira operação não parece ser bastante. A filtração pode ser rápida.

Quanto a fixação de dosagem, não a podemos determinar sem demorada experiência e para as differentes condições de água natural, conforme a situação. Um diagrama, na excellente obra de Imbeaux \& Debauve, indica para os differenntes graus de turbidez:

Grau 50 - coagulante por $\mathrm{m}^{3}$ 12gr.

Grau 75 - coagulante por $\mathrm{m}^{3}$. $15 \mathrm{gr}$.

Grau 100 - coagulante por $\mathrm{m}^{3}$ $17 \mathrm{gr}$.

Grau 150 - coagulante por $\mathrm{m}^{3}$ $.22 \mathrm{gr}$.

Grau 200 - coagulante por $\mathrm{m}^{3}$ $.27 \mathrm{gr}$. Grau 300 - coagulante por $\mathrm{m}^{3}$ 34 gr.

Parece-nos que a natureza da turbidez das águas dório Pardo exigirá mais forte dosagem na estação chuvosa.

O tempo para decantação também será melhor marcado pela experiência local: elle varia de meia hora a duas horas para a turbidez de grau 200 a 800.

A experiência para a dosagem se faz, como se sabe, em uma serie de garrafas e a dosagem assim obtida soffre uma redução de cerca de $25 \%$ para a pratica em grandes massas. Algumas vezes, quando a situação do serviço permitte, se pratica a operação em duas phases, misturando metade do coagulante em cada phase.

Veremos adiante como podem ser dispostas as obras da Empreza para este serviço.

Occorre-me lembrar quetalvez a excessiva turbidez na estação das chuvas seja devido às águas que correrm das estradas e carreiros dos cafezais corregando a argilla em poeira finíssima, e as extraordinárias desaggregações de terreno que formam as "barrocas" ou "mossorocas", phenomeno este que pode ser corrigido pelo desvio de águas e pela arborização.

Antes de terminar este capitulo citemos o exemplo dos estudos feitos para a purificação das águas do canal no intuito de abastecer Marselle. Estas águas são muito impuras e bastará dizer que do Canal se retirou (1908 a 1909) 17 cadáveres humanos, 3 cavallos, 108 porcos, 75 cães, 433 coelhos, 412 galinhas e 107 animais diversos (total 1.138 cadáveres de animais). Vê-se bem ahi é preciso não somente appplicar a lei de protecção de curso como também um processo de purificação mui enérgico para a nitrificação de grande carga de matéria orgânica proveniente das numerosas aglomerações humanas ribeirinhas (usinas, lavandeiras, etc). 
Depois de vários estudos, ficou rejeitado o alvitre de procurar "água de fonte" e aceito o de purificar aqquellas águas, comparadas às quais são puríssimas a do Riberirão Preto e as do Rio Pardo. Submetteo-se o tratamento a um concurso,no qual a questao principal é a esterilisação, e não simplesmente a clarificação de que precisamos para as águas do Rio Pardo.

[f.9]

Não descrevi estas experiências e os seus resultados: bastar-me-á dizer que um dos processos propostos e experimentados, para uma acção depuradora tão enérgica, foi o tratamento pelo sulfato de alumínio, concorrendo com os processos de ozona, dos filtros de areia (submersa e não submersa) e da esterillisação pelos raios ultra-violetas.

A água dos Canal contém por metro cúbico cerca de 90 gr. de carbonato de cal (calculado pela differença dos graus hydrométricos total e permanente): esta quantidade alcalina pode decompor cerca de 200 gr. de sulfato de alumínio hydratado: ora, com o tratamento apenas se limita a ajuntarr a água 30 a 75 gr. de sulfato de alumínio, todo este sal soffre a decomposição conhecida (alumínio insolúvel que fica nos filtros e sulfato de cal que incorpora ao existente na água) e, portanto, não fica na água tratada nenhuma quantidade de alumínio solúvel, conforme, aliás, a analyse contastou.

De entre várias observações feitas sobre o resultado das experiências, os relatórios mencionam uma diminuição notável da matéria orgânica, a saber as quantidades de oxygenio tomadas ao permanganato de potassa por um litro d'água para oxydação das matérias orgânicas em meio ácido são de 0,25 a 0,55 mg. e em meio alcalino de 0,20 a 0,30 o grau hydrotrimetrico augmenta devido ao accrescimo de sulfato de cal que substitue o carbonato de cal na reação chimica realisada. Uma dose de $45 \mathrm{gr}$. por metro cúbico faz desapparecer $20 \mathrm{mg}$ de carbonato de cal por litro d'água e o substitue $27 \mathrm{mg}$. de sulfato de cal. Estas variações, dizem os Relatórios, são assaz francas e pode-me considerar a água do canal, após o tratamento, como de boa qualidade no ponto de vista de sua mineralização.

Chamo a attenção para este caso interessante.

O tratamento da águas do Rio Pardo axige que se alcalinise pela cal. por ser baixo o seu valor hydrotimetrico.

Prevendo, neste rápido estudo, a necessidade remota de um tratamento mais rigoroso, no ponto de vista da redução de matéria orgânica, desnecessário se torna, de facto, indicar processos, porquanto a técnica do assumpto vae se aperfeiçoando de ano para ano, processos nos surgem e não se sabe qual será o preferível na occasião. Não posso, entretanto, deixar de fazer uma simples referencia aos ensaios da esterilização pelos raios

Ultravioletas, para águas claras ou previamente clarificadas, e ao processo de tratamento pelo hypoclorito de sódio ou outras substâncias similares. Este ultimo processo teve os seus opositores, que terão hoje cedido a evidencia dos factos, esclaricida principalmente na prática norte americana. O processo não substitui a filtração, quanto ao melhoramento das qualidades physicas da água, mas é um complemento da filtração, onde e quando se torne conveniente applicá-lo.

\section{III - SERVIÇO PELA EMPREZA: ÁGUAS DO RIO PARDO.}


A colheita das águas do Rio Pardo é feita na margem, a cerca de 5 metros por dois tubos munidos de ralos.

Dois grupos de motor-bombas electricas, cada uma de 25 hp., elevam, cada uma, 23 litros por segundo, ou $2.000 \mathrm{~m}^{3} \mathrm{em} 24$ horas, a altura de 48 metros a que se acham os filtros. Um terceiro motor auxilia os dois outros.

Os filtros tem as margens taludadas a $45^{\circ}$ e são estas e o fundo revestidos de alvenaria: a profundidade total é de 2,80 e a superfície de filtração é de $500 \mathrm{~m}$. quadrados para cada um, ou total de 1.500 metros quadrados. Na parte inferior do filtro estão os drenos, formados de tijolos em dois filtros, de tubos de barro em um; segue-se uma camada de 10 centímetros de pedra britada e outra de areia, de composição granulétrica várias, com espessura de 36 a $60 \mathrm{~cm} .:$ a camada filtrante e drenente occupa 0,68 a 0,90 e fica em cima della a altura d'água de 2,12 m e 1,90 m. esta variação na altura provem de se ir retirando a lama sem substituir logo a areia retirada, pratica esta a corrigir, conforme diremos adiante.

A Empresa conta com a superfície total dos três filtros, mas como um deve estar em limpeza e em descanço, devemos tomar apenas 1.000 metros quadrados com superfície filtrante disponível para o tratamento de $4.000 \mathrm{~m}^{3}$, que é o dispêndio das duas bombas, e não $6.000 \mathrm{~m}^{3}$ :

Dos filtros a água segue por um aqueduto formado de tubos de cimento, diâmetro 0,40 , declividade 0,002 , segundo informa a empresa. O dispêndio deste, a meia secção (conforme corria na ocasião), é de cerca de 52 litros por segundo, ou proximammente 4.500 litros diários: a plena

[f.11]

secção a vazão será dupla, ou 9.000 litros diários.

Depois de correr uma extensão de $7 \mathrm{~km}$, proximamente, a água é retomada em outra estação de bombas para a elevar ao reservatório situado a cerca de $3 \mathrm{kkm}$ e na altitude 43 ; a sua capacidade é de 2.000 metros cúbicos. A altura de elevação é de 38 metros, a força dos motores é $20 \mathrm{HP}$, e as bombas, em 2 grupos, elevam, cada uma $2.000 \mathrm{~m}^{3}$, o emissário, formado de uma linha de tubos de aço, tem diâmetro de 12 ".

Ocorre, ainda, fazer uma referencia ao serviço existente e no qual a adducção do Rio Pardo entre como elemento novo e predominante no futuro.

O plano, com o novo elemento, comprehende 3 reservatórios:

$1^{\circ}$ alto, cota 57 capacidade $1.300 \mathrm{~m}^{3}$

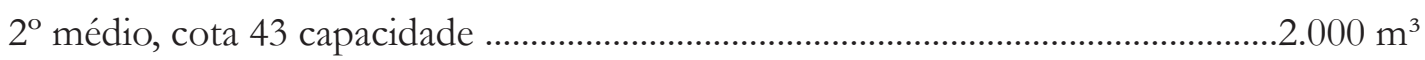

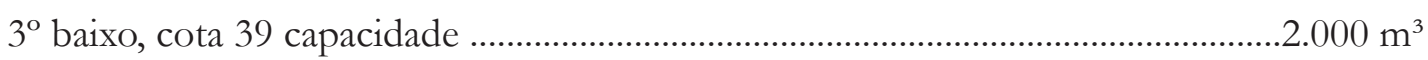

Obtivemos da Empresa estes últimos dados.

Passemos agora a critica positiva do novo serviço de aducção do Rio Pardo.

Já me referi a qualidade das águas do Rio Pardo e as analyses, anexas, com as Notas que se acompanham, instruem o assumpto. Lembro, também, que fiz a inspecção local em época de menor turbidez, sendo nesta occasião colhidas novas provas, submettidas a exame nos dois laboratórios que antes procederam a analyses, um por conta da Prefeitura, outro por conta da Empresa: com isto quero ter dados fora da suspeição com que foram acolhidas algumas analyses.

Não tendo ainda o resultado dos novos exames, será elle apreciado nas Notas que acompanham a sua apresentação: podemos, entretanto, dizer desde já o que convem fazer, quanto 
a processo, porquanto a dosagem, sejam qualquer o resultado da analyse actual, só pode ser determinada pela experimentação, conforme vimos em outro capitulo.

Comecemos pela colheita d'água na margem.

A situação que descrevemos acima indica como preferível a captação mais ao centro do curso, se ahi houver profundidade conveniente em estiagem. A captação na margem pode ser mantida com o saneamento dos bairros próximos, até cerca de 100 metros a montante, e uma vez verifica-

do que as águas do Palmeiras se misturam logo com as do Rio e não correm junto a margem, como que formando uma corrente de águas differentes no seio do próprio rio, conforme se verifica em tantos outros cursos e no oceano.

Para melhorar a captação marginal é também preciso limpar e aterrar o local e desviar para jusante as águas de descarga dos filtros e todas as que, na estação das chuvas, possam trazer impurezas deixadas a superfície, principalmente, as de proveniência humanas. Convém estabelecer uma latrina para o pessoal, a qual descarregará a cerca de 30 metros a jusante, sendo sufficiente esta distancia porque no local a velocidade do rio é bastante forte.

Lembro a Empresa, como de seu próprio interesse, a seguinte solução, a examinar por uma experiência, se entender que lhe convém.

Se o terreno alluviano das várzeas das margens fosse arenoso, a solução que passo a indicar, a exemplo do que se tem feito em outras localidades, seria de seguro êxito e dispensaria o emprego de coagulante. Sendo, porém, argilloso e repousaando, como parece, sobre pedra, resta saber se existe um lastro de cascalho ou areia e se este é bastante rico em água subterrânea que desce da encosta, a qual se misturará com a que affluirá para o dreno (galeria ou poços) vinda do próprio rio e passando por uma clarificação natural para chegar ao dreno.

Este dreno seria então estabelecido no sopé da encosta: a várzea junto delle, seria saneada por meio de valetas que evitam a estagnação: também seria preciso favorecer a nitrificação das substancias de origem vegetal, a superfície, limpando-a e reduzindo a vegetação a arvores esparsas e convenientemente tratadas. Parece-me que no caso de existência de uma base de rocha, por onde desce a água, melhor é estabelecer a galeria filtrante que os poços. No caso dos poços, a captação nesta se faz por um siphãode várias bocas, em percurso, e descarregando no poço de aspiração das bombas a manutenção do seu funcionamento é muito simples, desde que os tubos tanham as juntas hermeticamente fechadas.

Passemos ao exame da installção mecânica. Comprehende duas estações,uma na tomada, outra de relai, no aqueduto, conforme descrevi.

Elles não dão os $6.000 \mathrm{~m}^{3} \mathrm{em} 24$ horas de que falla a consulta da Prefeitura (volume que, aliás, me parece desnecessário, para já, conforme mostrei).

Elles dão apenas, conforme informa a propria Empreza, $2.000 \mathrm{~m}^{3}$ diários, cada grupo de cada estação. Em rigor sódevemos contar com esta quantidade, porquanto é preciso ter de reserva o outro grupo. Portanto, não restringido o desperdício do consumo, e se forem necessários 4.000 $\mathrm{m}^{3}$, deve a empresa collocar um terceiro grupo para $2.000 \mathrm{~m}^{3}$, em cada estação de modo a ter dois em trabalho e um em descanso.

A installação mecânica, portanto, deficiente, mormente se tiver de das em 12 horas diurnas o volume necessário em 24 horas. Esta conclusão se applica as duas estações elevatórias.

Já vimos que os filtros offerecem a superfície de $1.500 \mathrm{~m}^{2}$ mas que só devemos contar para o calculo da efficiencia, com $1.000 \mathrm{~m}^{2}$, e não conforme faz a Empresa. Porque um filtro deve ser considerado como em descaso para limpeza, reforma da camada superior, etc.

É inadmissível a prática de ir tirando a lama superior, sem refazer a camada na espessura 
que for julgada conveniente pelo resultado analytico do effluente, salvo se a experiência provar que se deve adotar mais forte espessura na estação das águas mais turvas para ir progressivamente reduzindo ao mínimo na estiagem.

Vimos que a espessura drenante e filtrante tinha, a principio $22 \mathrm{~cm}$ para o suporte de pedra vrtiada ou cascalho, $60 \mathrm{~cm}$, para a areia: tirando-se successivamente a lama, medimos, no ultimo filtro, apenas $36 \mathrm{~cm}$. Há exemplos de filtros com esta fraca altura da camada de areia, mas com mais forte espessura na camada de supporte. Só a analyse, depois de regularizado o processo da previa clarificação e prefiltração, poderá mostrar se aquellas espessuras são sufficiente, o que possivelmente pode acontecer, desde que o principal objetivo seja sempre clarificar e não esterilizar.

Mas neste caso terá cabimento o ante-projeto que me expoz o engenheiro da Empresa, a saber: tratar pelo alumen: approveitar os tanques dos filtros para a decantação, reelevar e procederem a filtração rápida antes de elevar a água pela aqueduto.

Adoptado o processo do coagulante e da filtração rápida, com ou sem pressão, é preciso não desviar das regras que a prática americana tem

Estabelecido para o seu processo. Chamo especialmente a attenção para a lavagem da areia e sua composição granulética, para a dosagem automática e perfeita do coagulante, para a regularização das entradas de água e para o critério analytico, companhando as variações nas condições da água.

Chamo especialmente a attenção para mistura perfeita, em duas phases ou em uma só e para a dosagem. Existem, como se sabe, para estas operações vários dispositivos e apparelhos e ellas devem ser feitas por completo antes da entrada nos tanques de decantação, embora se tenha de forçar a elevação a mais de um metro, o que é fácil attender visto se ter de providenciar sobre motores mais poderosos que os installados.

Visto dispor a empresa do serviço hydroeletrico de luz e força, parece-me que ella prefere a elevação para a filtração rápida sob pressão à filtração rápida por gravidade ou mesmo no processo Gulmiére (paredes filtrantes verticais) ou similar. São questões de economia privada da Empresa, e sobre as quais nada temos a dizer, desde que o resultado purificador satisfaça o desideratum sanitário.

Antes de terminar este assumpto, ultimo que me cumpri abordar, lembro a neccesidade de proteger as installações de tratamento depurador contra possíveis contaminações provinientes da merodia do guarda, situada mui próxima, e tendo um tanque de lavagem de roupas encostado a uma das bacias. A areia para filtração também deve ser protegida, e não exposta como está. Bastará proteger areia e bacias por meio de uma cerca bem fechada.

Os poços de inspecção do aqueduto, a começar pelo inicial, sahindo fora da terra vinte centímetros ou mais, devem ser convenientemente fechados.

Sobre os reservatórios e a rede de distribuição não fui interpellado e certamente nada há que dizer, attendendo a reconhecida idoneidade dos engenheiros encorregado dos serviços de projecto e execução.

[f.14]

Recomendamos alguns ensaios sobre a escolha do coagulante, no posto de vista da economia dos serviços e no da efficácia do tratamento:

a) Pelo alumen.

b) Pelo permanganato de potássio.

Resolvida a questão do coagulante, é preferível a Empresa se orientar pelo critério do processo Puech-Chabal, a saber, uma separação gradativa antes do emprego dos filtros lentos ou 
dos rápidos.

Na revista eau et hygiene, $\mathrm{n}^{\circ} 12$ (out, 1911) encontrará interessante nota sobre a filtração das águas contendo argilas colloidaes. $\mathrm{O}$ facto desta revista ser claramente propagadora do processo Puech-Chabal, não impede de se reconhecer a boa razão dos argumentos apresentados.

$$
\text { IV - Conclusão }
$$

A Comissão Especial da Câmara Muncipal de Ribeirão Preto formulou dias series de quesitos, a 18 de Março de 1912, que passamos a responder de accordo com os resultado das analuses annexas e das Notas que as acompanham. Notemos que os quesitos se referem exclusivamente ao serviço de água do Rio Pardo.

Primeira Série de quesitos:

$1^{\circ}$ A água do Rio Pardo, tal como está sendo filtrada, pode ser considerada "água de alimentação" e fornecida ao povo sem prejuízo de sua saúde?

$2^{\circ}$ Caso não o possa: é o facto devido a ser água refractaria a filtração, ou deve-se attribuílo ao systema adoptado para os filtros ou ainda a defeitos na construção delles. Nestas últimas hypotheses, como corrigir a falta, de forma a água ser empregado no abastecimento da cidade sem prejuízo da saúde publica?

$3^{\circ}$ Tratada previamente pelo processo de coagulação pelo alumen e cal, pode essa água tornar-se boa e ser, sem inconveniente, fornecida a população desta cidade?

$4^{\circ}$ No caso affirmativo: a) em que proporção devem ser empregados os referidos agentes? b) a dosagem delles deve ser sempre a mesma ou pode variar de uma para outra época do anno, conforme o grau de turbidez da água? c) neste último caso, qual o critério a adoptar-se na referida dosagem?

$5^{\circ}$ Não sendo esse tratamento efficaz, qual o processo a seguir?

$6^{\circ}$ qual o systema de vigilância a adoptar-se para assegurar-se a boa execução do serviço d'água tratada por tais processos, e verificar-se com frequência que se mantém de boa qualidade a água entregue ao consumo?

Resposta:

Ao $1^{\circ}$ : de acordo com a analyse das águas tiradas por mim a 7 de Maio de 1912, a água filtrada é de boa qualidade: attendendo, porém, a turbidez muito maior na estação das chuvas, o processo de tratamento deve ser modificado conforme exposto acima.

Ao $2^{\circ}$ : ver a resposta ao $1^{\circ}$

Ao $3^{\circ}: \operatorname{sim}$

Ao $4^{\circ}$ : as dosagens de coagulante devem ser determinadas por experiência, variada com as condições de turbidez, de accordo com o critério indicado na exposição, capítulos II e III.

Ao $5^{\circ}$ : Prejudicado.

Ao $6^{\circ}$ : É preciso recorrer as analyses frequentes.

Segunda serie de quesitos:

$1^{\circ}$ as obras executadas (apparelho de captação, e localisação delle, aparelhos de elevação 
da água, installação destes, tanques de filtração, canalisação, etc ) estão de conformidade com os preceitos a que devem obedecer as obras dessa natureza, e tem solidez e perfeição requeridas?

$2^{\circ}$ As installações que essas obras representam tem a capacidade para seis milhões de litros em vinte e quatro horas, isto é, são capazes para o effectivo fornecimento desse volume d'água, devidamente filtrada e em qualquer epocha do ano?

$3^{\circ}$ É de boa applicação e de accordo com technica moderna, o tratamento da água de rio, destinado ao abastecimento público de uma cidade e para todos os mysteres, pelo simples processo de filtração em filtros de areia de typo construído pela Empresa, não precedido da decantação, da coagulação por agentes chimicos, da prefiltração ou quaesquer outros processos prévios semelhantes, especialmente tratando-se de rio cujas águas accusam, em certa epocha do anno, tão alto grau de turbidez e de matéria em suspensão, que é classificada pela própria Empresa de "verdadeira" lama?

Resposta

Ao $1^{\circ}$ : vê-se que algumas destas obras por acabar, sendo interrompidas, talvez, com o alarmente resultado do serviço na estação de máxima turbidez. Outras precisam dos corretivos indicados no capitulo III. Outros são elementos correctos, conforme resulta da apreciação feita (cap.III).

Ao $2^{\circ}$ : A installação mecânica e filtrante não tem capacidade para seis milhões de litros em vinte e quatro horas: para isto está previsto espaço afim de installar novos grupos.

Ao $3^{\circ}$ : a simples filtração lenta é de boa applicação e de uso corrente em muitos serviços de águas: mas, para certas águas, como as do Rio Pardo, são necessários os processos especiais, conforme indicado nos capítulos II e III.

Santos, 31 de Maio de 1912.

[fl.1]

\author{
Observações e Notas Explicativas do Esquema do \\ Plano Diretor de Ribeirão Preto.
}

1) Cabe de inicio explicar que o plano, como indica o titulo, é apenas esquemático, devendo sofrer as modificações julgadas necessárias à melhor adaptação às condições locais, sejam topográficas, técnicas, econômicas, financeiras ou sociais.

Não há, pois, rigidez absoluta na sua programação, mas, uma vez analizado, aceito e aprovado, deverá ter a sua contribuição sempre garantida. Deve também, ser dado o maior empenho na sua conservação e consequente execução.

2) Devido a razões de ordem econômica e financeira, foi mantida quase sem alteração a parte atual existente da cidade.

A modificação fundamental, entretanto, é a que se refere à localização de fábricas, desvios, bem como, nova localização da estação dos Campos Elíseos.

Não comporta no esquema do Plano Diretor, apresentar detalhes e estabelecer soluções que dependerão de estudos minuciosos e, sobretudo, da analise local. Daí, a razão de, apenas, fazerse a indicação esquemática como possível orientação para a solução futura.

[f.2]

3) O Plano Diretor cuida de preferência da extensão progressiva da cidade à medida do seu desenvolvimento. Trata, antes de mais nada, de prevenir o crescimento ordenado, dentro 
de um programa preestabelecido, em vez de deixá-lo livre, ao sabor dos interesses particulares isolados, de difícil e antieconômico solução posterior.

Como se disse, ele conserva a parte atual existente, não lhe alterando quase nada, para dedicar-se às zonas adjacentes de possível expansão da cidade n’um futuro não muito remoto.

4) No plano distinguem-se duas grandes áreas:

$1^{\mathrm{a}}$ - área urbana, da cidade propriamente dita, incluindo a área atual e a futura expansão;

$2^{\circ}$ - área agrícola ou rural, que também poder-se-ia chamar de suburbana.

Para esta última não foi feito plano de extensão regional que embora necessário, poderá ser objeto de estudos posteriores, baseados nos elementos levantados em todo o município.

5) O sistema viário é constituído pelas vias de circulação, caracterizadas pelas avenidas radiais e perimetrais de contorno externo e de circuito interno, de maneira a distribuir e facilitar o tráfego que definem a estrutura do plano diretor. São as seguintes: Avenida 9 de Julho, Independência, do Café e Jerônimo Gonçalves formando o perímetro interno de irradiação da cidade propriamente dita. A perimetral exterior é como se segue: partindo do pontilhão da Estrada do Guatapará sobre linhas férreas segue pelo leito atual da Mogiana até encontrar o Ribeirão Preto e daí pela Estrada de Sertãozinho ou pelo Parkway em direção a Monte Alegre, atinge-se o alto da Vila

Tibério que será cortada por uma nova Avenida em diagonal até atingir novamente o Ribeirão Preto: pelo curso deste segue o parkway até o córrego do Tanquinho e por este último em direção à nascente, chega-se ao prolongamento da Avenida Independência, no cruzamento desta com a Estrada do Morro do Cipó; contornando ainda pelas divisas do perímetro urbano com a zona agrícola chega-se finalmente ao ponto de partida na estrada do Guatapará, no pontilhão do Emboaba.

As transversais no sentido leste-oeste são: Avenida Capitão Salomão, Avenida Pernambuco, Avenida Nova do Parque Cemitério e do Aeroporto marginando a Estrada de Ferro S. Paulo Minas; no sentido norte-sul as longitudinais mais importantes são: Avenida Independência, Avenida Saudade-Saldanha Marinho, prolongamento e alargamento de ambos os extremos da rua Castro Alves e finalmente, as marginais às linhas da Estrada de Ferro Mogiana, prolongamento e alargamento de ambos os extremos da rua Castro Alves e finalmente, as marginais às linhas da Estrada de Ferro Mogiana.

6) As avenidas perimetrais externas, nos limites da cidade separando-a da zona agrícola, foram delineadas para não só estabelecer o tráfego perimetral de intercomunicação de bairros, como fixar e definir de modo claro o limite do perímetro urbano. Somente dentro deste perímetro é que serão permitidas as divisões de áreas para arruamentos e loteamentos, obedecendo aos traçados do plano diretor.

Alem dos limites do perímetro urbano não deverão ser permitidas aberturas de ruas e vendas de lotes. Este é um meio de impedir o crescimento desordenado e nocivo à comunidade.

7) As vias radiais são caracterizadas pelas estradas de rodagem de ligação dos municípios. Dentro do urbano, tornam-se importantes vias de função e objetivos bem definidos.

8) Nos cruzamentos das vias radiais com as perimetrais bem assim como de outras transversais, são previstas praças de circula-

ção e de orientação de tráfego.

9) Cintura verde e espaço livre assinalam o tratamento que deverá ter as áreas intercaladas nas quadras, e das áreas ao longo dos córregos.

O reflorestamento das mesmas, com essência de varias naturezas, é destinado a crear não 
só a amenidade de clima, tão necessária a Ribeirão Preto, como constituir, também, uma reserva florestal de inestimável valor econômico.

Estas faixas de vegetação na zona de expansão da cidade e em geral ao longo das várzeas visam por outro lado, manter uniforme o regime dos rios, bem como fazer o saneamento da baixada, com o mínimo de despesas. Esse reflorestamento, seja de eucaliptos, seja de qualquer outra essência de fácil obtenção e plantio poderá ser feito paulatinamente e com perseverança. No fim de poucos anos, com dispêndio suave ganhou a cidade uma grande área de vegetação protetora e amenizadora de clima, além do espaço para lazer e recreação, e, riqueza patrimonial adquirida.

Seria, talvez, este um dos primeiros pontos do Plano Diretor a ser imediatamente estudados, analisada, para ser posto logo em execução.

Os espaços verdes ao longo dos rios permitirão a creação dos parkways que, alem de facilitarem as ligações de zonas, possibilitarão o estabelecimento de centros esportivos e de recreação ativa no seu percurso, valorizando a região, tornando-a, além disso, mais atraente. Surgem, então, os parkways dos rios: Ribeirão Preto, Retiro, Tanquinho e República.

Dentro, ainda, do programa dos espaços verdes, encontra-se a área do Bosque que foi aumentada de mais do triplo do atual.

É que estando livre de qualquer loteamento, no momento atual, pode ser preservado para o reflorestamento e dada a sua proximidade do centro, poderá vir a ser um dos pontos de maior atração da cidade de Ribeirão Preto.

[f.5]

10) Quanto ao zoneamento a área urbana foi dividida nas seguintes zonas:

$$
\begin{array}{ll}
1 & \text { - ZCI - Zona Comercial de } 1^{\text {a }} \text { categoria. } \\
2 & - \text { ZC2 }- \text { Zona Comercial de } 2^{\text {a }} \text { categoria. } \\
3 & - \text { ZI }- \text { Zona Industrial. } \\
4 & - \text { ZRI - Zona Residencial de } 1^{\text {a }} \text { categoria. } \\
5 & - \text { ZR2 - Zona Residencial de } 2^{\text {a }} \text { categoria. } \\
6 & - \text { ZR3 - Zona Residencial de } 3^{\text {a }} \text { categoria. } \\
7 & - \text { ZA - Zona Agrícola ou Rural. }
\end{array}
$$

O Código de Obras deverá regulamentar o zoneamento. Além dessas zonas, poderá haver núcleos de categoria diferente situados nas zonas de especificação diversa. A determinação desses núcleos dependerá de fatores indicados pelo desenvolvimento a tendências da cidade.Torna-se necessário uma revisão do atual código de posturas, adaptando-o às novas condições do plano. $\mathrm{O}$ decreto 6.000 da Prefeitura do Distrito Federal poderá servir para orientação do novo código.

\section{1) Zona Industrial}

Qualquer cidade deve ter, como principio, a sua zona industrial perfeitamente definida com possibilidades de expansão futura em áreas de baixo preço, próximo às linhas férreas, afastada da zona residencial, não muito distante do centro comercial e finalmente a jusante dos ventos dominantes.

No caso de Ribeirão Preto, as características acima foram em parte observadas e pode desde já ser prevista com a regulamentação adequada em face do esquema do Plano Diretor. Localizou-se a zona industrial ao longo das linhas férreas e justamente nos bairros cujas tendências industriais são hoje manifestas.

12) $\quad$ Aeroporto

Aproveitando as condições topográficas favoráveis deverá a Municipalidade reservar a área retangular de 2 quilômetros por 3 quilômetros, situada ao lado da Metalúrgica, no Alto, para a 
construção futura do Aeroporto, tão necessário como importante hoje ao desenvolvimento da cidade. No esquema as pistas foram figuradas apenas como indicação provável, elas, entretanto deverão seguir a direção e instrução especiais do Ministério da Aeronáutica. A indicação futura aerogare e da estação ferroviária, também, são sugestões a serem apreciadas oportunamente.

$\operatorname{xxxxx}$

Concluindo, cabe mais uma vez frisar que o plano se apresenta como indicação visando metodicar o crescimento e expansão futura da cidade. Sua exequibilidade é viável dentro de um programa amplo, sadio e entusiástico, destinado às populações vindouras, como oferta da geração atual que com a melhor boa vontade, delineia, sugere, inicia e aspira, também, vê-lo realizado.

Rio de Janeiro, 4 de Dezembro de 1945.

José de Oliveira Reis.

[f11]

Notas para a Palestra em Ribeirão Preto em 8 de agosto de 1955.

Tema: Urbanismo e a sua influência no município.

Comecemos por conceituar o Urbanismo na sua acepção mais moderna na técnica do planejamento. Outrora definia-se o Urbanismo como a arte do planejamento. A preocupação dominante fixava-se no aspecto físico no qual sobressaia-se o efeito artístico, seja paisagístico seja arquitetônico. Os traçados visavam obter perspectivas deslumbrantes, ainda que com sacrifício das condições topográficas (Belo Horizonte), ou jungidos a uma rigidez ortodoxa do sistema de xadrez, como da nossa cidade (Ribeirão Preto) e de muitas outras.

Essa fase primaria do urbanismo evoluiu expandindo-se alem dos limites da cidade, para o campo, para a região, para o Estado e a Nação e até Nações para se transformar em "URBS" - universo - ou "URBANISMO" como propôs Gaston Bardet - extrapolando assim no espaço e no tempo. A conceituação moderna de Urbanismo pode ser encontrada na definição de Thomaz Adams - urbanista americano - quando diz:

"Urbanismo é a arte de planejar o desenvolvimento das cidades, com objetivo de assegurar saúde, segurança e condições de trabalho aos seus habitantes, prevendo eficientes e convenientes formas de circulação e fomentando o bem estar geral".

Verifica-se que além das condições físicas deve o urbanismo moderno preocupar-se com a saúde, segurança, condições de trabalho, em suma, com o bem estar geral. Nestas condições, cresce o âmbito de suas prerrogativas anteriores e a nova técnica de planejamento vai-lhe fornecer os meios para alcançar a sua finalidade.

O Planejamento nada mais é do que a previsão organizada, a coor-

denação e a adaptação dos meios aos fins, estabelecendo a ligação entre a pesquisa e a realização. Hoje, mais do que nunca, é necessário planejar todos os atos da atividade humana. Por isso mesmo o planejamento é, também, uma nova técnica social. 
Com mais forte razão a cidade sendo um organismo vivo, a necessidade do planejamento nos seus diferentes tipos: físico, econômico social, cultural e de ares, se impõe para uma vida melhor aos seus habitantes.

Carlos Maria Dellla Paolera, ilustre urbanista argentino, autor de inúmeros planos de melhoramentos de Buenos Aires, criador do Dia Mundial do Urbanismo, instituído na data de 8 de Novembro essa comemoração universal, e também criador do símbolo de urbanismo - a trilogia "AR - SOL - VEGETAÇÃO", também criou o lema que se aplica a síntese do planejamento:

\section{“ORGANIZAR BEM PARA VIVER MELHOR".}

Eis aí, em poucas palavras a enorme tarefa que nos cabe a todos, para que possamos, também, usufruir um pouco de uma vida melhor.

É, pois, planejando que dotaremos a nossa sociedade de meios adequados ao bem estar geral, proporcionando à população condições higiênicas, condições de segurança, condições de trabalho, condições de segurança, condições de recreação, condições culturais, condições econômicas, condições financeiras, enfim, condições sociais que conduzam à felicidade do homem.

É isso que se propõe o Urbanismo moderno dentro da nova técnica de Planejamento Social. É mais do que dar um bonito plano de cidade no papel e cuja realização muitas vezes fica na aspiração. Vê-se então que a "arte de construir cidade" na sua restrita concepção foi hoje ultrapassada para abranger todo o município e, ir além, estendendo-se por toda a região ecológica.

Daí distinguir-se no planejamento de área os seguintes tipos: local, urbano, regional, e nacional, situando-se cada tipo nas suas respectivas limitações, isto é, o local abrangendo pequena área da cidade, tal como os loteamentos particulares ou públicos, o urbano no que se refere a área urbana da cidade, o regional estendendo-se

[f.3]

por todos as zonas limítrofes de mesmas condições físicas, geográficas, sociais, agrícolas etc, e finalmente, o nacional abrangendo a nação como um todo. Há o planejamento estadual nem como o municipal adstrito as fronteiras administrativas é, na maioria dos casos, a observada na prática atual. Assim, cada município tem a sua prerrogativa de organizar o seu plano de desenvolvimento e expansão de sua cidade, vilas e povoados.

De certo modo, há uma lógica no planejamento municipal condicionado a prescrição constitucional que estabelece a autonomia do município. E, ainda que assim não fosse, bastava à conceituação do município definida pela "Carta dos Municípios" que diz:

"O município é o um grupo natural da sociedade, constituído por um conjunto de famílias e organizado como unidade política primária"

A ideia do planejamento de área inicia-se por essa "unidade política primaria” e se amplia por toda uma região.

Eis porque a influencia do Urbanismo no Município torna-se um imperativo elementar que toda Administração Municipal, independentemente das questões político-partidárias, tem que considerar, se realmente quer fazer alguma cousa útil aos seus munícipes.

Ocorre, então, em primeiro lugar, estabelecer um plano de urbanização para a cidade. Este pode ser na forma de um plano diretor no qual as linhas mestras das vias arteriais são figuradas, a distribuição dos espaços verdes acha-se assinalada, o zoneamento regulamentado, enfim, as características físicas do planejamento urbano ficam definidas. Pode ainda ser por um estudo mais aprofundado de planejamento consentâneo onde às diversas fases do mesmo se processem de acordo com a técnica especifica e na seguinte ordem:

1- Definição do problema a resolver.

2- $\quad$ Pesquisa

3- $\quad$ Plano 
4- Programa

5- $\quad$ Aprovação

[fl.4]

6- Execução

7- $\quad$ Revisão

Aplica-se essa técnica aos cinco tipos de planejamento enunciados anteriormente: físico, econômico, social, cultural e de área.

Este último abrange, por assim dizer os quatro primeiros.

Visamos, com esta explanação, procurar esclarecer algumas duvidas, por ventura existente, com relação à função do urbanismo e situá-lo dentro da moderna concepção.

A evolução dos fatos vai obrigando instintivamente as municipalidades a se unirem umas às outras. Um exemplo magnífico desse entendimento é a realidade dos Congressos dos Municípios. Dessa congregação um grande número de medidas salutares aos municípios tem surgido. Ainda há pouco no ultimo Congresso realizado em S. Lourenço instituiu-se a "Operação Município" pela qual os auxílios financeiros aos municípios será um fato. Sem uma solida base financeira, não haverá autonomia do município. Essa autonomia é tanto mais necessária quanto mais progresso desejamos para o município. Vale dizer: maiores recursos financeiros, mais independência, mais iniciativa, mais arrojo, mais desenvolvimento, o que exige, para tudo isso, mais organização, ou seja, o planejamento adequado. Entende-se por planejamento aquele que abrange o município e não fique restrito apenas a área urbana da cidade. Já vimos que a extrapolação do urbanismo de sua concepção primaria para outra mais ampla estendendo-se pela região do "City Planning" para o "Regional Planning" e deste para o "National Planning", é uma conquista superada. O s problemas que afetam as cidades estendem-se aos municípios.

Esses problemas em Urbanismo, segundo ainda Gaston Bardet, podem ser enquadrados em cinco grandes classes gerais:

1- Problemas de Circulação.

2- Problemas de Higiene e Conforto.

3- Problemas Sociais e Econômicos.

4- Problemas Estéticos.

5- $\quad$ Problemas intelectuais e espirituais.

Ao encararmos cada um desses problemas devemos ter em vista

a solução do conjunto. Existe entre eles uma interligação intima.

Uma solução isolada pode afetar desfavoravelmente outra parte. Por exemplo, os problemas de circulação duma cidade estão ligados ao da região e por consequência de outras cidades. É função precípua das municipalidades cooperar com o plano rodoviário, quer estadual, quer nacional. O plano rodoviário marcará as diretrizes do sistema de circulação regional ao qual o plano diretor da cidade deverá estar jungido. De igual modo, o plano ferroviário determinar condições explicitas ao município as quais o planejamento regional ficará, obviamente, adstrito.

Poderíamos nos alongar em citações e exemplos sobre cada um dos problemas distribuídos nas cinco grandes classes. É, porém desnecessário esclarecer um assunto que está no consenso de todos.

Vejamos, agora, em poucas palavras, o caso objetivo de Ribeirão Preto.

Ribeirão Preto é o município, sem favor nenhum, padrão de progresso entre os municípios brasileiros. De acordo com o ultimo censo - $1^{\circ}$ de Julho de 1950 - tinha somente a cidade a população de 65.081 habitantes dos 92.190 apurados para o município. A sua área em relação à de 
muitos outros municípios não é das maiores, pois abrange a $1.142 \mathrm{kkm}^{2}$, ou seja praticamente a mesma do Distrito Federal que é de $1.171 \mathrm{~km}^{2}$. Corresponde uma densidade de $80 \mathrm{hab} / \mathrm{km} 2$.

De acordo com uma publicação do IBGE - intitulado - "S. Paulo - População - 1954", verificamos que essa população se distribui pelos 50.731 domicílios de todo o município dos quais cerca de 20.000 são urbanos, 3.500 suburbanos e os restantes 27.600 pela zona rural.

Ainda de acordo com recenseamento de 1950 havia, naquela data, cerca de 11 mil prédios na cidade, o corresponde quase a 2 domićlios por prédio. Em publicação recente de 14 de maio do corrente ano, no jornal "A Cidade", lemos que o progresso desta cidade tem sido de tal ordem que mais de 1000 prédios são construídos mensalmente, sejam 12. 000 por ano. Deve haver engano. Provavelmente o jornal "A Cidade" quis dizer anual, o que já é bastante para uma população que está atingindo a casa dos 100.000 habitantes.

[fl.6]

Em 1940 pelo recenseamento de $1^{\circ}$ de setembro a população do Município de Ribeirão Preto era 79. 783 almas; quer dizer que no período de 10 anos cresceu de 12.377 habitantes, ou seja, um aumento grosso modo de 1200 almas por ano, ou ainda 100 habitantes por mês.

Pelo censo realizado pelo S.N.F.A em março de 1955, segundo recentes informações fornecidas pela Prefeitura Municipal, a população da cidade é de 82.814 habitantes, e o numero de prédios é de 15.241. Parece que o surto de construção de novos prédios acompanha o rápido crescimento da população.

É insofismável que Ribeirão Preto é uma cidade progressista e como seu título de "Capital do Oeste de S. Paulo", vai vencendo inúmeras dificuldades e ultrapassando todas as expectativas.

O seu desenvolvimento, a sua expansão não podem ser feitos a mercê das improvisações e indiscriminadamente. É preciso controlá-los. Já é tempo, pois, de dotar a cidade de um plano de melhoramento e expansão e ainda mais, atendendo às altas responsabilidades de cidade pioneira e cultural, dotar o Município de um Plano Regional, abrangendo não só o Plano Diretor da área urbana da cidade como também a zona rural e regiões limítrofes, interessando os Municípios vizinhos de Jardinópolis, Sertãozinho, Brodósqui, Guariba, Araraquara, Rincão, S. Simão, Cravinhos e Serrana, para apenas citar os que confirmam diretamente com os limites administrativos do Município de Ribeirão Preto.

Não se compreende hoje uma cidade da importância de Ribeirão Preto não ter o seu plano de urbanização. Como frisamos no começo desta palestra o plano de urbanização não se limita apenas ao traçado físico das ruas, esta é da circulação. Ė algo mais que exige a cooperação de todos, pois, como vimos, abrange todas as atividade humanas.

Daí a razão por que se prefere hoje usar-se o termo planejamento de área por ser de sentido mais amplo que o de urbanização, empregado comumente às áreas restritas dos limites urbanos da cidade. De qualquer modo, entretanto, não se pode conceber a ausência de um plano numa cidade como Ribeirão Preto. Os melhoramentos, a extensão, o desenvolvimento, o progresso da cidade em todos os sentidos, devem estar programados,

[f.7]

organizados, previstos e orientados, tanto quanto possível, afim de evitar prejuízos insanáveis e soluções precárias, improvisadas, pela falta de um planejamento adequado.

Foi muito de propósito que escolhi o tema desta palestra para alertar no município a influência do urbanismo e procurar, ao mesmo tempo, fazer sentir a necessidade imperiosa de ser organizado quanto antes uma comissão ou um órgão técnico, ou departamento na municipalidade, para iniciar os estudos de planejamento do Município de Ribeirão Preto e, obviamente, da área urbana da cidade, a suburbana e a rural imediata, afim de dotar este próspero município de um plano regional e de um plano diretor urbano que regulem o crescimento e expansão da cidade e município dentro das boas normas do Urbanismo. Esses estudos demandam tempo e perseverança. 
Estou certo, porém, que o patriotismo e os alevantados propósitos dos administradores e ilustres vereadores desta terra não deixarão passar mais tempo para que Ribeirão Preto possa oferecer mais esse exemplo de pioneirismo municipal de cidade progressista.

Cabe-me agora dar uma breve explicação a respeito de um esquema de plano diretor que tive a oportunidade de elaborar em 1945, para a área urbana de Ribeirão Preto, de acordo com os parcos elementos de que dispunha naquela época. Na ligeira exposição a guisa de observação e notas explicativas do esboço apresentado, esclarecia ao então Prefeito Dr. Alcides Sampaio que o "plano era apenas, esquemático, devendo sofrer as modificações julgadas necessárias à melhor adaptação às condições locais, sejam topográficas, técnicas, econômicas, financeiras ou sociais".

Partindo dessa premissa, estou bem a vontade para discutir o esboço, cuja apresentação teve o mérito de, a meu ver, ser um inicio de conversa. Como afirmei, também, não havia rigidez absoluta na sua programação, o que significa uma porta aberta para uma serie de melhores sugestões que seriam analisadas e discutidas por quem de direito.

È evidente que a análise e a discussão já deveriam ter sido iniciados, pois dez anos já decorreram. Desconheço, entretanto, qualquer iniciativa a esse respeito. De qualquer modo, é preciso que seja instituído um órgão departamental para a elaboração do planejamento regional, como frisei.

O esquema foi baseado em presunção de possibilidade, pois os elementos de que dispunha eram escassos, como já disse, não me sendo fornecidos outros por inexistentes. Tanto que na época a informação segura a respeito da Mogiana era ter esta abandonado o estudo da variante do Zé Jaques e preferido atingir o Barracão pelo alto da Vila Tibério. Em virtude disso, o esquema procurou se orientar nessa diretriz resultando, daí, disposições no traçado que possivelmente hoje seria profundamente alterado é o que diz respeito às novas áreas de expansão, cujos arruamentos não mais obedeceriam a pragmática dos traçados habituais de simples prolongamentos dos logradouros existentes, na observação rígida de suas respectivas continuidades. Hoje procurar-se-ia estabelecer um sistema de vias arteriais de caráter periférico as super quadras, dentro das quais seriam projetadas (Neighborhood unit - Unité de Voisinage), cujas populações de 5 ou 6 mil habitantes gozariam das mais amplas vantagens que oferecem esses tipos celulares da cidade moderna. Por outro lado, o sistema de parques, espaços livres, áreas verdes, os parkways ao longo dos córregos e nas zonas baixas inundáveis e desvalorizadas deveriam ser objeto de seria cogitação da Municipalidade, pois o beneficio a economia, a salubridade que essas áreas proporcionam à população, justificam pelnamente as despesas que a Prefeitura teria com a sua aquisição e transformação em parques. Nesse particular o esquema sugeriu providencias que se tivessem sido postas em pratica há dez anos não teríamos que lamentar, como agora, a sua falta. Além do cinturão verde preconizado no esquema ligado ao sistema de parques, bosques, etc, como aproveitamento do bosque exixtente e ampliando-o de cerca de 3 vezes, bem como o reflorestamento das várzeas dos córregos do Ribeirão Preto, Retiro, Tanquinho e República, havia a preocupação de dotar a área urbana de uma serie de pequenas praças e jardins de amenização tão necessárias a vida da cidade.

Tratou, também, o esquema da reserva de area necessária a expansão do aeroporto, num retângulo de $2 \mathrm{~km} \times 3 \mathrm{~km}$, permitindo assim a construção de pistas de mais de $3 \mathrm{~km}$ de comprimento, hoje preconizado para os aviões a jato.

\section{[fl.9]}

Pela nova planta na escala de 1:10.000 da cidade que recentemente recebi do Sr. Prefeito José Costa verifico que houve uma expansão bem grande de novos loteamentos neste espaço de dez anos, além dos limites urbanos.

Urbanisticamente seria de desejar que tais loteamentos fossem mais restritos. È fácil explicar, pois os mesmos visaram antes de mais nada o sucesso financeiro em detrimento do lado 
urbanístico.

Contudo, não é para se desesperar porquanto muita coisa ainda pode ser salva e corrigida.

È esperando que isso aconteça para o futuro que peço licença para insistir mais uma vez, pois, nunca é tarde para começar.

Procuramos formar uma sadia mentalidade de urgente necessidade de um plano de urbanização para Ribeirão Preto, estendendo para todo o Município e se transformando no Plano Regional da Capital do Oeste abrangendo toda a zona de influencia nos municípios vizinhos. 

